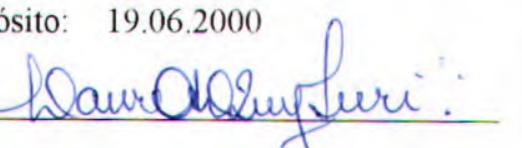

\title{
Visualização na WWW: Estudo e Implementação de um Sistema
}

\author{
Alexandre Donizeti Alves
}

Orientadora: Profa. Dra. Maria Cristina Ferreira de Oliveira

Dissertação apresentada ao Instituto de Ciências Matemáticas e de Computação - ICMC-USP, como parte dos requisitos para obtenção do titulo de Mestre em Ciências - Área: Ciências de Computação e Matemática Computacional.

USP - São Carlos

Junho de 2000 
Este trabalho é dedicado a todas as pessoas que, de alguma forma, contribuíram para a sua realização.

"Faça as pequenas coisas de uma maneira extraordinária; seja o melhor em seu setor. Você não deve deixar sua vida trilhar um caminho comum; faço algo que ninguém jamais fez, algo que irá deslumbrar o mundo. Mostre que o princípio criativo de DEUS trabalha em você. Nunca se importe com o passado. Embora seus erros sejam tão profundos quanto o oceano, a alma em si não pode ser engolida por eles. Tenha a inabalável determinação de mover-se em sua trilha sem se embaraçar com pensamentos limitadores de erros passados."

Paramahansa Yogananda 


\section{Agradecimentos}

A Deus, por ter me dado forças e condições para concluir mais um trabalho.

Aos meus pais, que sempre me deram condições para estudar, permitindo que mais essa etapa da minha vida fosse cumprida de uma forma digna.

À minha orientadora Maria Cristina, pelo apoio e compreensão, estando sempre disposta a me ajudar. Para mim foi um prazer e um privilégio trabalhar com uma pessoa pela qual tenho o maior respeito e admiração. Pouquíssimas vezes tive a oportunidade de trabalhar com alguém com quem eu me entendesse tão bem.

À minha esposa Marinalva, que esteve comigo durante quase todo o mestrado, passando também por muitas das minhas dificuldades e sempre me trazendo uma palavra de conforto. Passamos por muitas coisas juntos nesse período, mas valeu a pena e como valeu a pena.

À professora Rosane, que desde o início me deu a maior força, principalmente em alguns momentos difíceis pelos quais passei no primeiro semestre do mestrado.

Aos amigos Igor e José Geraldo, pelo caráter, paciência e disposição em me ajudar. Suas ajudas foram essenciais no desenvolvimento de muitos trabalhos e principalmente na minha própria formação.

Ao professor João Benedito, que foi a pessoa que mais me incentivou a fazer o mestrado e foi quem me abriu as portas na USP.

Ao amigo Edmilson, que morou comigo por mais de um ano e me ajudou muito em diversas ocasiões.

Aos colegas do Grupo de Computação Gráfica, Carlos Eduardo (irmão), Veridiana, Wesley, Luís Fernando, Alex, Ygor e Eric, pela ajuda e companheirismo.

Aos funcionários do ICMC, e em especial, à Marília, Beth e Laura, que sempre estão dispostas a nos ajudar.

Ao $\mathrm{CNPq}$, pelo apoio financeiro.

À USP, pela oportunidade. 


\section{Sumário}

Índice de Figuras ......................................................................................... vii

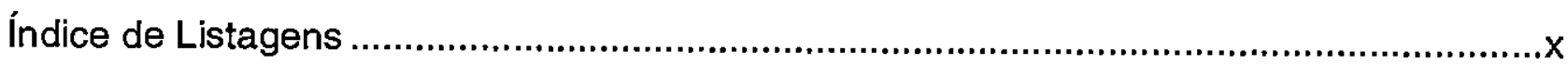

Resumo

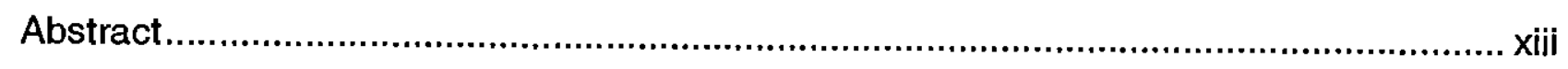

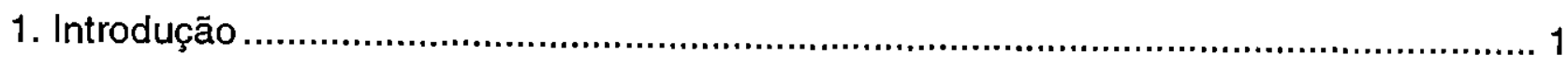

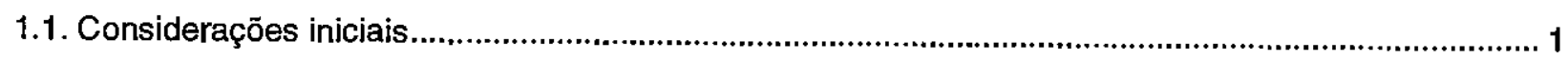

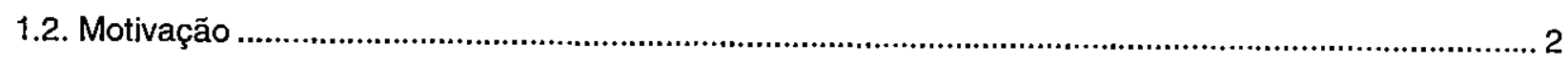

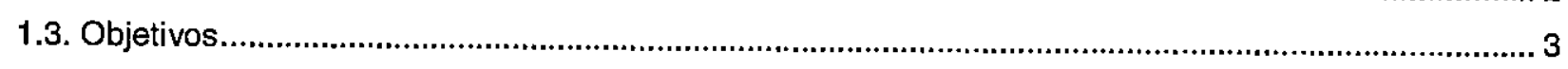

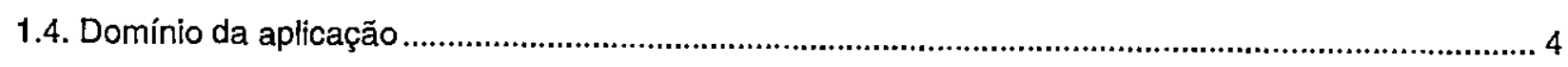

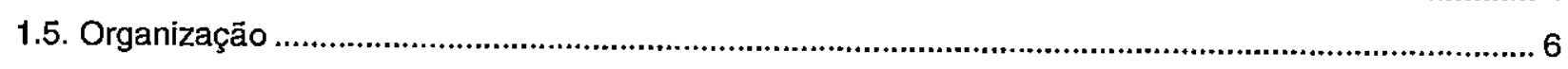

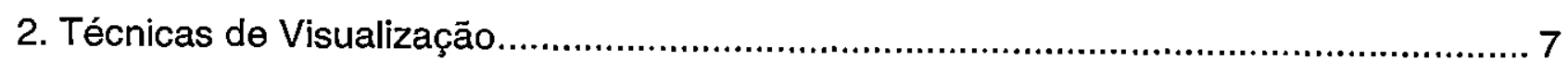

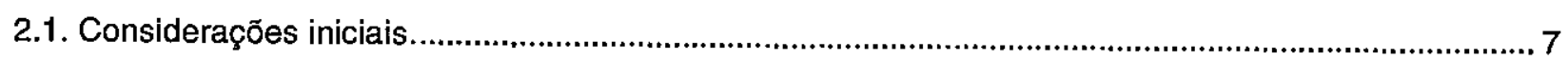

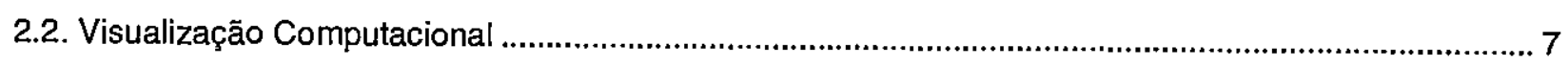

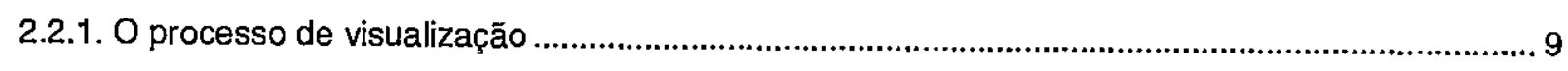

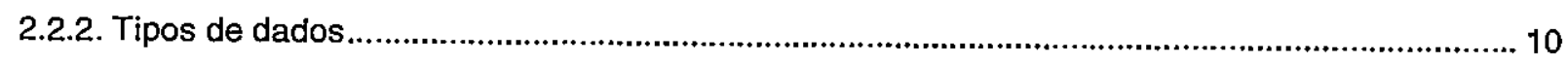

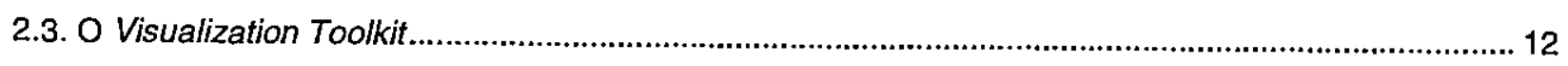

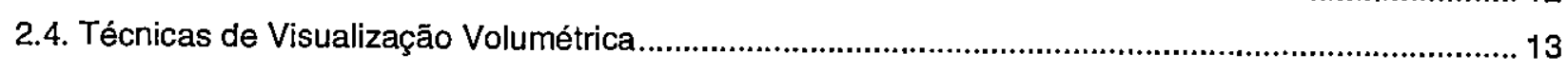

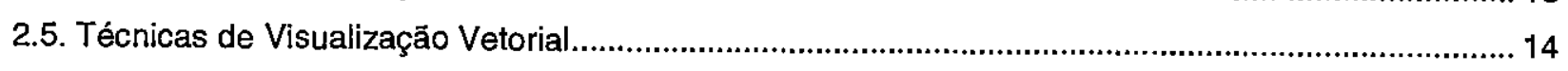

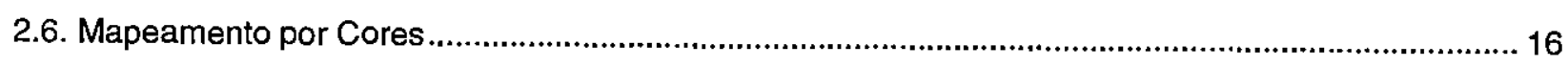

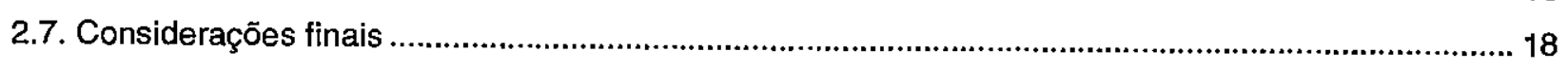

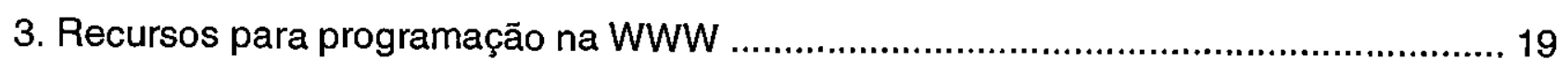

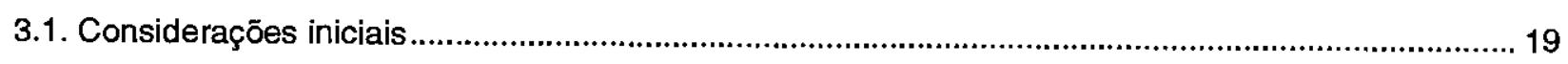

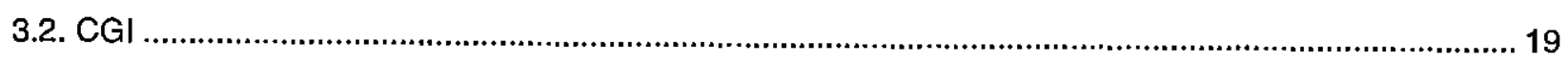

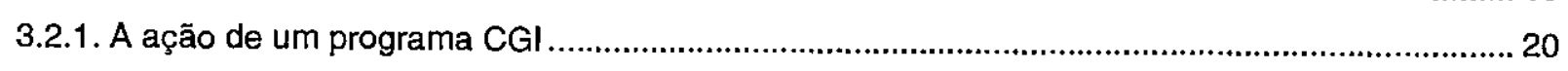

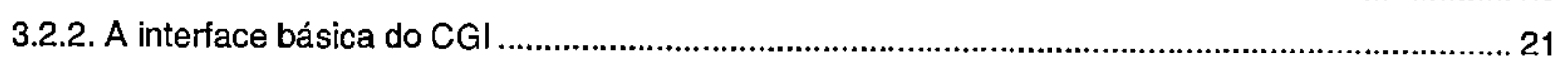

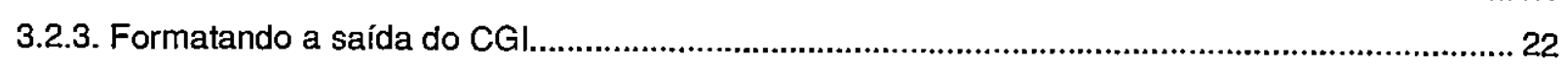

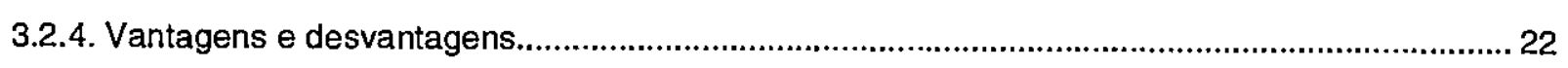

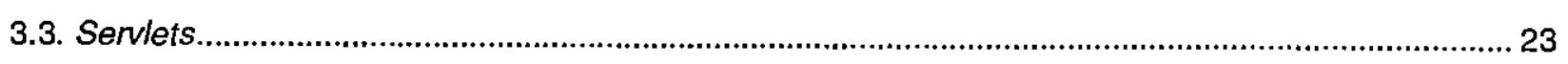




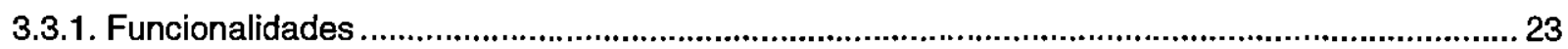

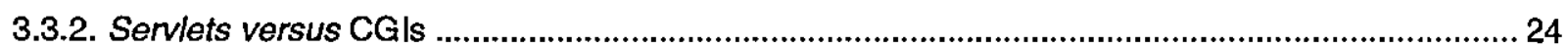

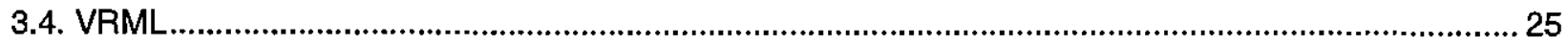

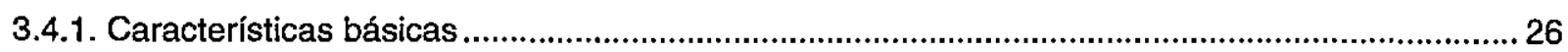

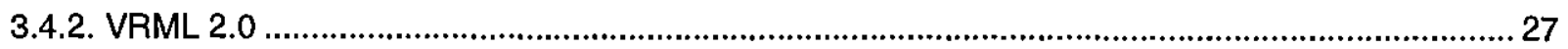

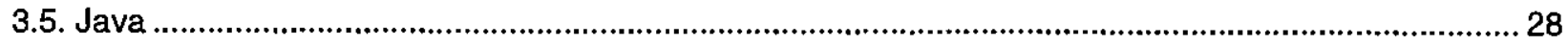

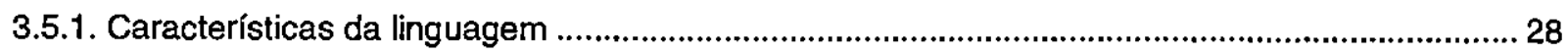

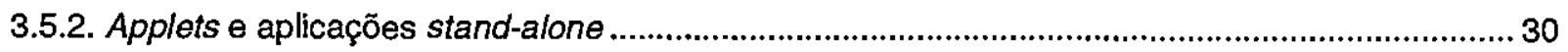

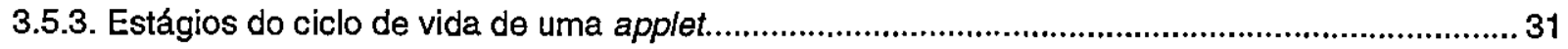

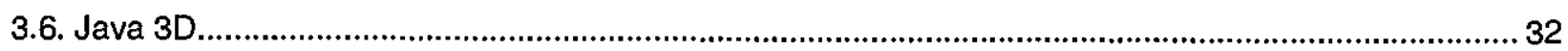

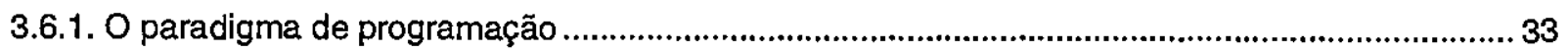

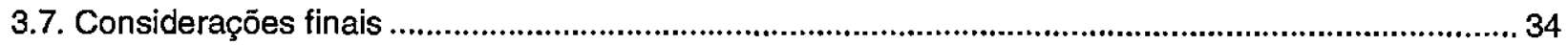

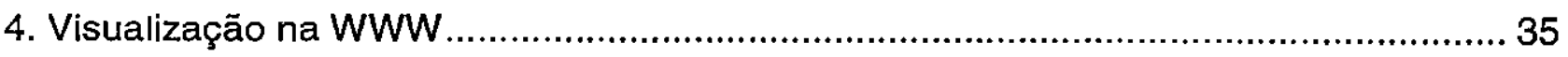

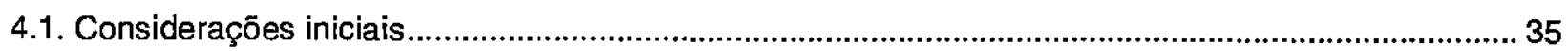

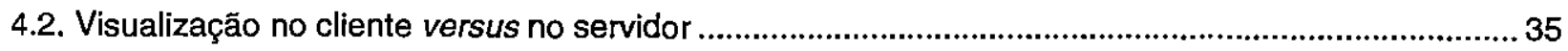

4.3. Um modelo de referência para a Visualização...................................................................................... 36

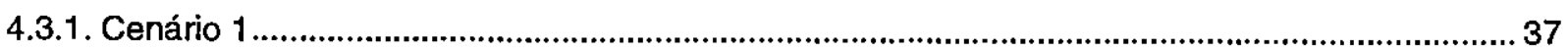

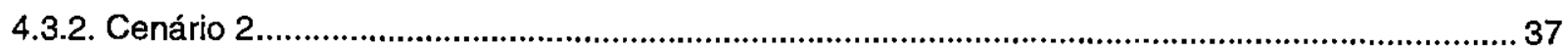

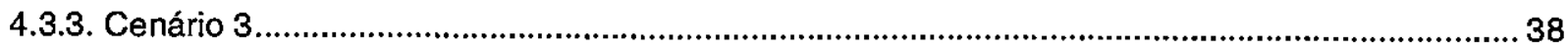

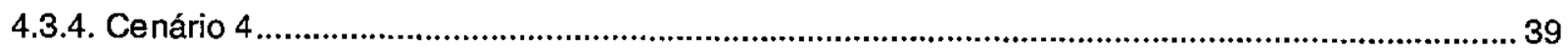

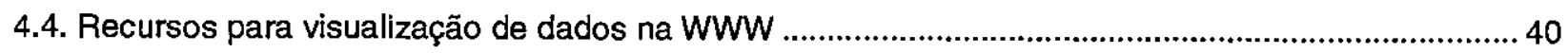

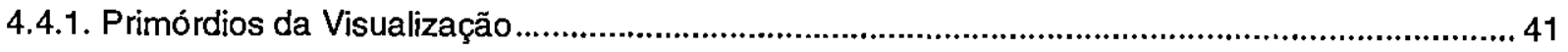

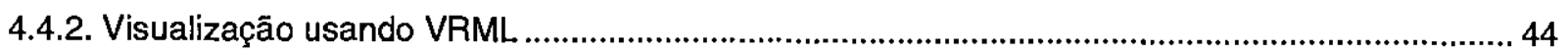

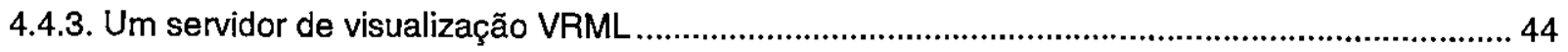

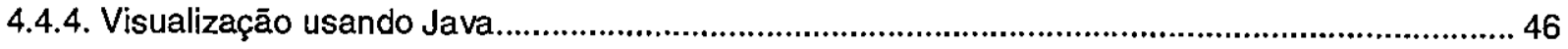

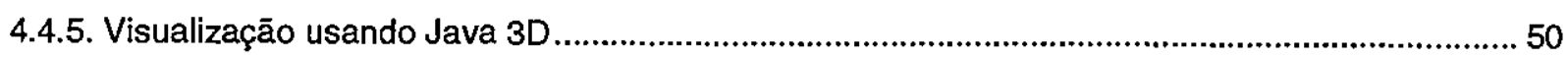

4.4.6. Visualização usando VRML, Java e a EAI............................................................................. 51

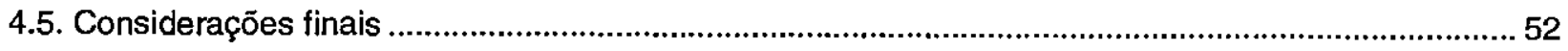

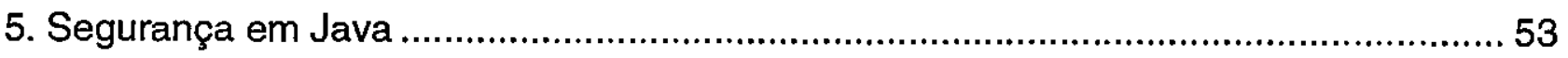

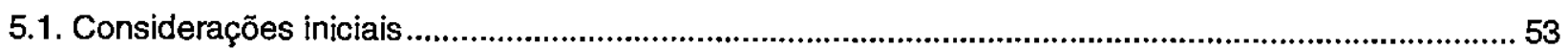

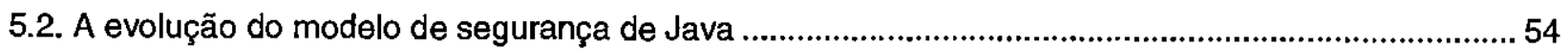

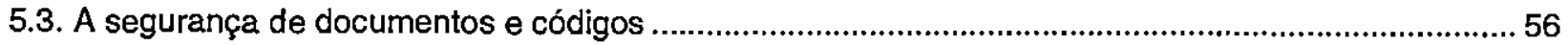

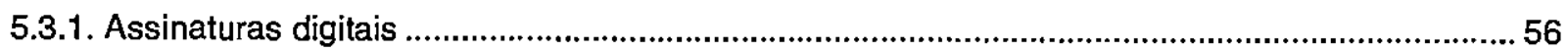

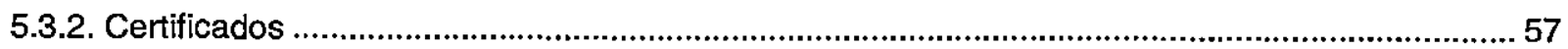

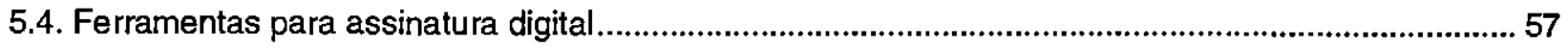

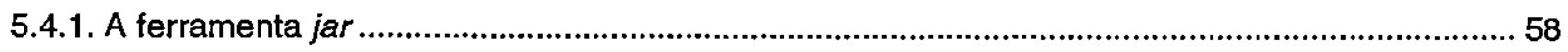

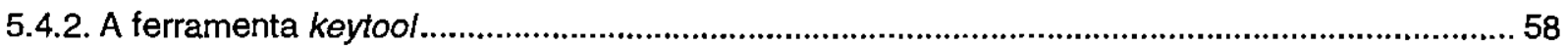

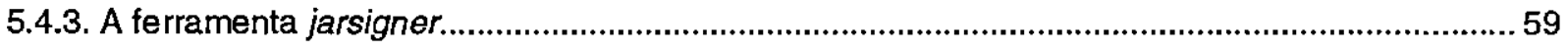

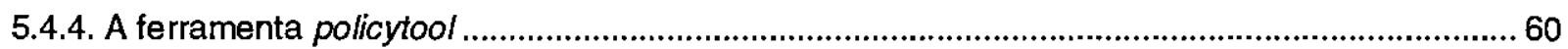




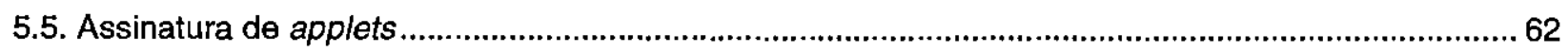

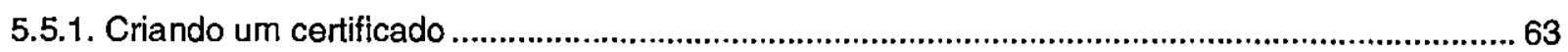

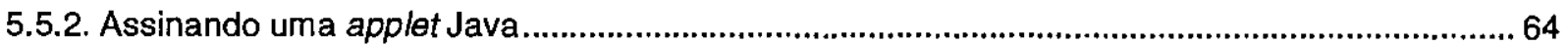

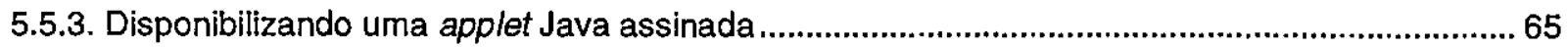

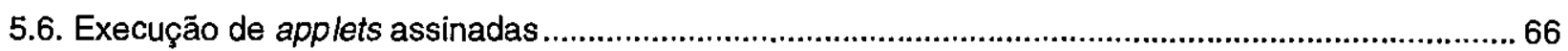

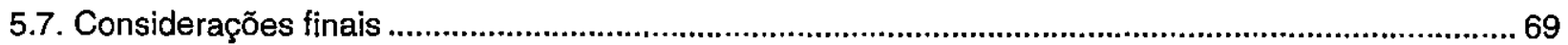

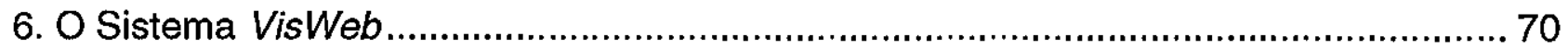

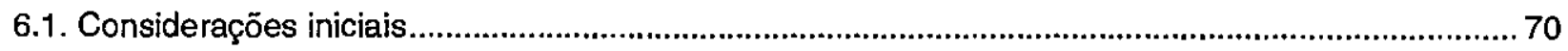

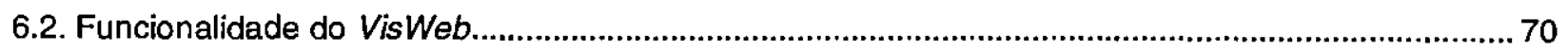

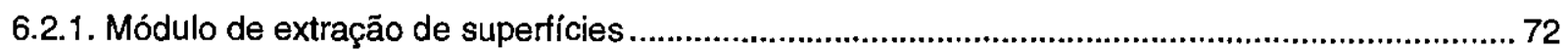

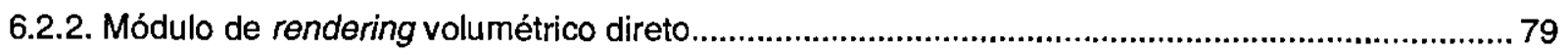

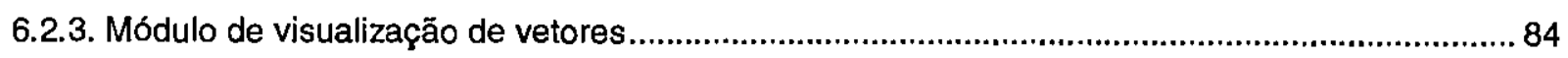

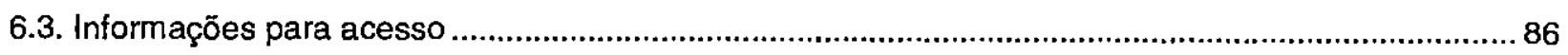

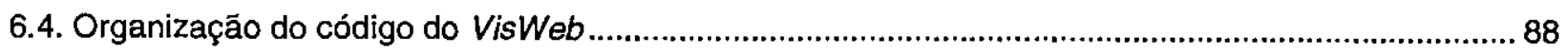

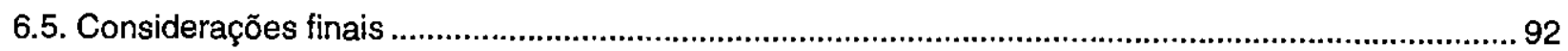

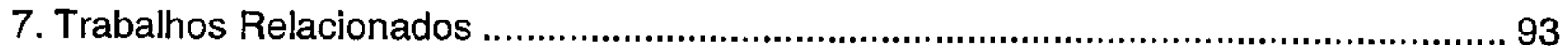

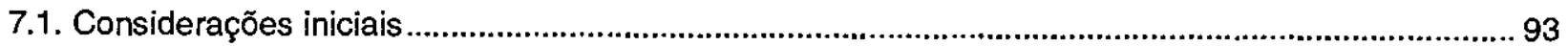

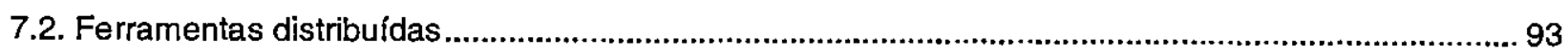

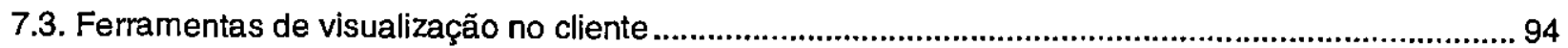

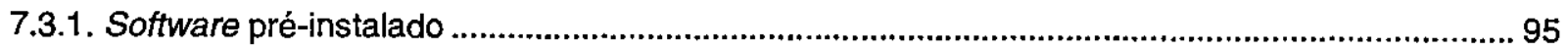

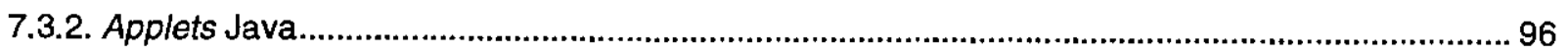

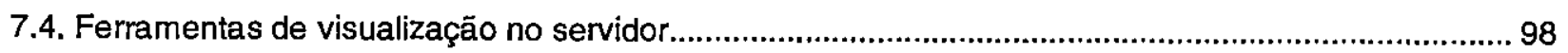

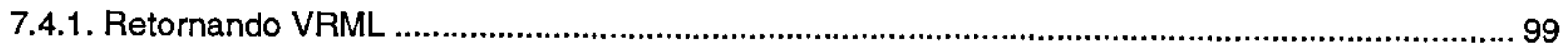

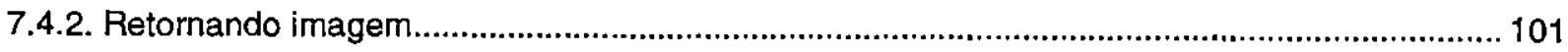

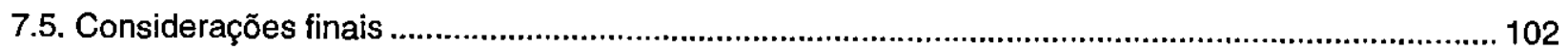

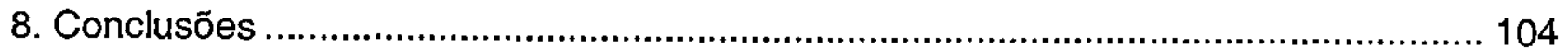

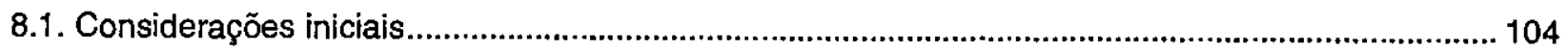

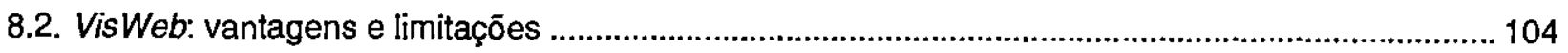

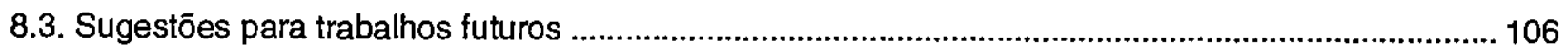

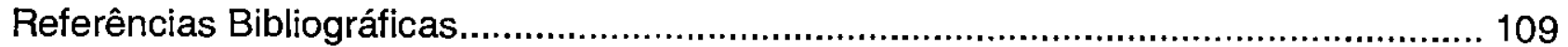

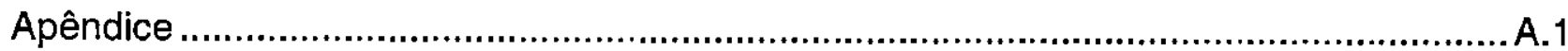




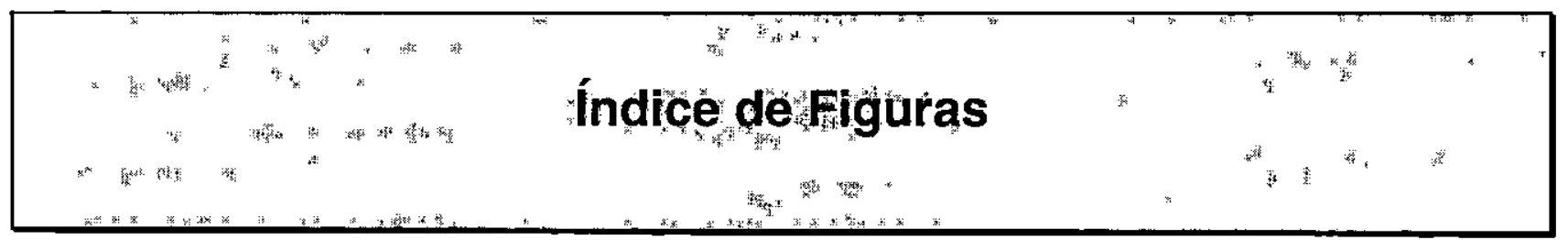

Figura 1.1 - Neurônios visualizados por extração de superfícies. 5

Figura 1.2 - Visualização volumétrica dos dados de neurônios ......................................................................5 5

Figura 1.3 - Visualização do campo vetorial em torno de um neurônio ...........................................................6

Figura 2.1 - Análise científica e feedback com o auxílio da visualização [Min97b]......................................... 9

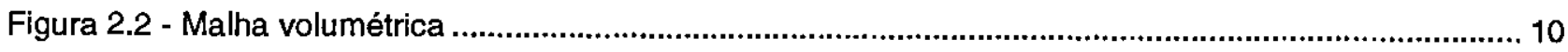

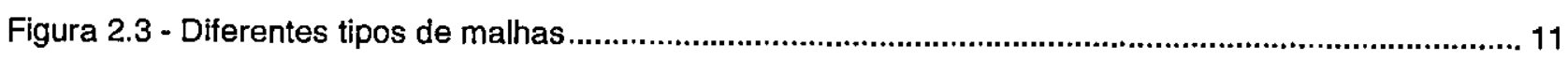

Figura 2.4 - Conexāo entre Fontes, Filtros e Mapeadores....................................................................... 13

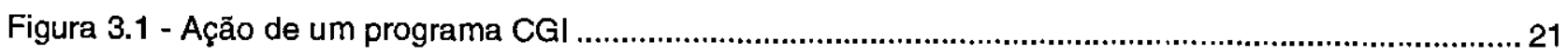

Figura 3.2 - Representação do grafo de cena em VRML............................................................................ 26

Figura 3.3 - Processo de compilação e execução em Java ...........................................................................28

Figura 3.4 - Exemplo de um grafo de cena em Java 3D [Sow97] .............................................................. 33

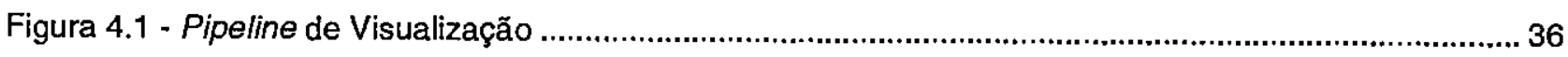

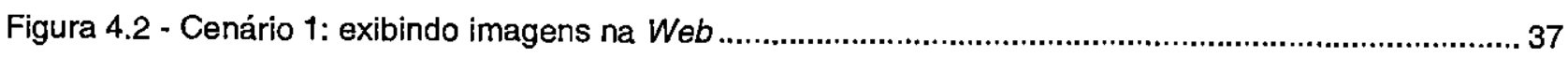

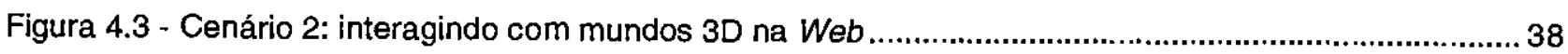

Figura 4.4 - Cenário 3: visualizando dados pela Web..............................................................................39

Figura 4.5 - Cenário 4: requisitando a visualização pela Web ....................................................................... 40

Figura 4.6 - Exemplo de visualização usando MPEG [Sch98] ................................................................... 42

Figura 4.7 - Exemplo de um formulário HTML [Sch98] ............................................................................ 43

Figura 4.8 - Exemplo de uma visualização usando Java e VTK [Sch98] ..................................................... 49

Figura 4.9 - Exemplo de uma visualização usando Java 3D......................................................................51

Figura 4.10 - Exemplo de uma visualização usando VRML, Java e EAI [Sch98] .......................................... 52

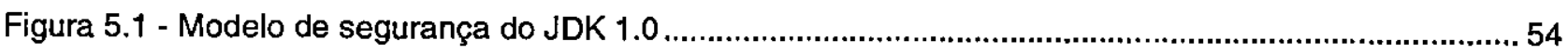

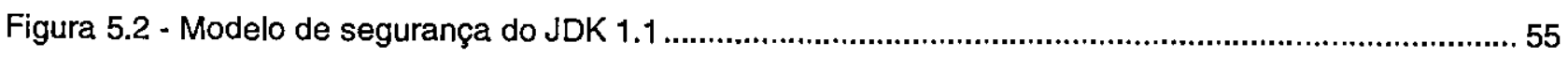

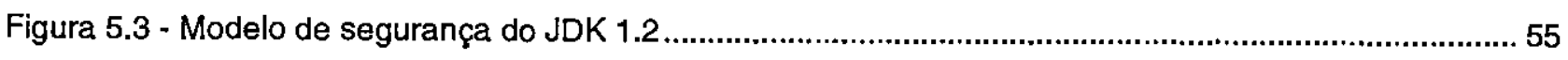

Figura 5.4 - Janela principal da ferramenta gráfica policytool .......................................................................6 60

Figura 5.5 - Janela principal da ferramenta gráfica HTMLConverter ..........................................................6 66

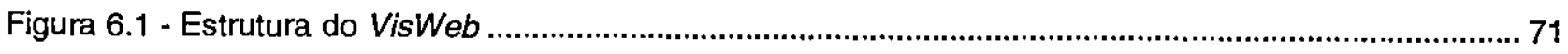

Figura 6.2 - Janela da página principal do VisWeb ................................................................................. 71

Figura 6.3 - Janela da página para acesso aos módulos do VisWeb ......................................................... 72

Figura 6.4 - Estrutura da applet de extração de superfícies......................................................................... 73

Figura 6.5 - Janela principal da applet de Extração de Superfícies ................................................................. 73

Figura 6.6 - Janela de definição do arquivo de dados................................................................................... 74

Figura 6.7 - Janela de exibição de mensagens de erro .............................................................................. 74

Figura 6.8 - Janela para busca e seleção do arquivo de dados.................................................................. 74 
Figura 6.9 - Janela de exibição das informações do arquivo de dados ........................................................75

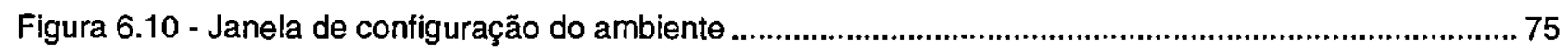

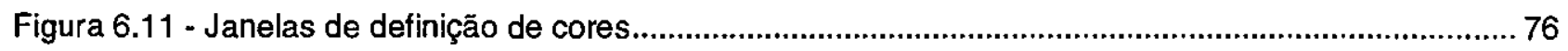

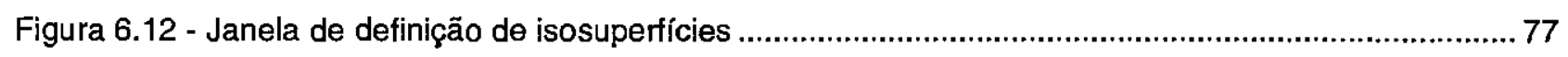

Figura 6.13 - Janela de definição de um plano de corte ..............................................................................77

Figura 6.14 - Janela de definição de uma animação............................................................................................. 78

Figura 6.15 - Funções de interação do VTK operacionais em Java .............................................................79

Figura 6.16 - Estrutura da applet de rendering volumétrico direto ................................................................ 80

Figura 6.17 - Janela principal da applet de Rendering Volumétrico Direto .................................................... 81

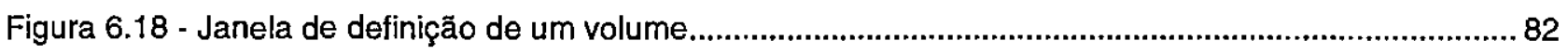

Figura 6.19 - Janela de definição de intervalos de opacidade utilizando uma tabela default .......................... 82

Figura 6.20 - Janela de definição de intervalos de opacidade utilizando uma tabela personalizada ..............83

Figura 6.21 - Estrutura da applet de visualização de vetores ........................................................................ 84

Figura 6.22 - Janela principal da applet de Visualização de Vetores............................................................. 85

Figura 6.23 - Janela de definição de vetores............................................................................................ 86

Figura 6.24 - Janela da página para acesso às informaçöes iniciais............................................................. 86

Figura 6.25 - Interface interna da janela principal da applet de rendering volumétrico direto ........................ 90

Figura 6.26 - Interface intema da janela de definição de volume ................................................................... 91

Figura 6.27 - Interface interna da janela de definição de intervalos utilizando uma tabela default.................92

Figura 7.1 - Janela principal da ferramenta Vis5D [Hib00] ........................................................................95

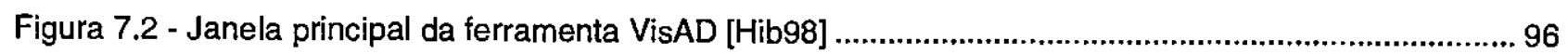

Figura 7.3 - Janela principal da ferramenta VisWiz [Mic97] .................................................................... 97

Figura 7.4 - Janela principal da applet Visible Human Viewer [Cha98] .......................................................98

Figura 7.5 - Página principal do Serviço de Visualização da Qualidade do Ar [Woo96]................................. 99

Figura 7.6 - Página do VTK para definição de parâmetros de uma visualização ........................................... 100

Figura 7.7 - Exemplo de uma visualização com VRML............................................................................... 100

Figura 7.8 - Página principal da ferramenta Prolet .................................................................................. 101

Figura 7.9 - Interface com o usuário da ferramenta Prolet [Eng98] ....................................................... 101

Figura 7.10 - Página principal da ferramenta CurVis ............................................................................ 102

Figura 7.11 - Página da ferramenta CurVis que exibe a visualização definida na Figura 7.10 ................... 102

Figura A.1 - Pipeline para extração e exibição de isosuperfícies....................................................................1

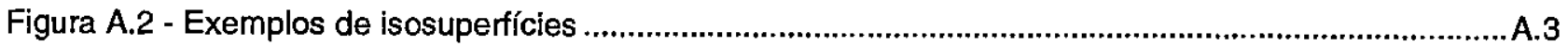

Figura A.3 - Pipeline para visualização de planos de cortes em isosuperfícies..............................................3

Figura A.4 - Exemplos de planos de corte aplicados às isosuperficies ilustradas na Figura A.2 ..................A.5

Figura A.5 - Pipeline para visualização de volumes ....................................................................................5

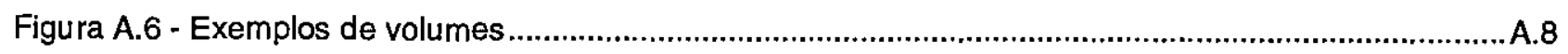

Figura A.7 - Pipeline para visualização de de sub-volumes.....................................................................

Figura A.8 - Exemplo de sub-volumes................................................................................................10

Figura A.9 - Exemplos de planos de corte nos volumes ilustrados na Figura A.6 .....................................A.10

Figura A.10 - Pipeline para visualização de campos vetoriais ..................................................................11 
Figura A.11 - Exemplos de campos vetoriais 


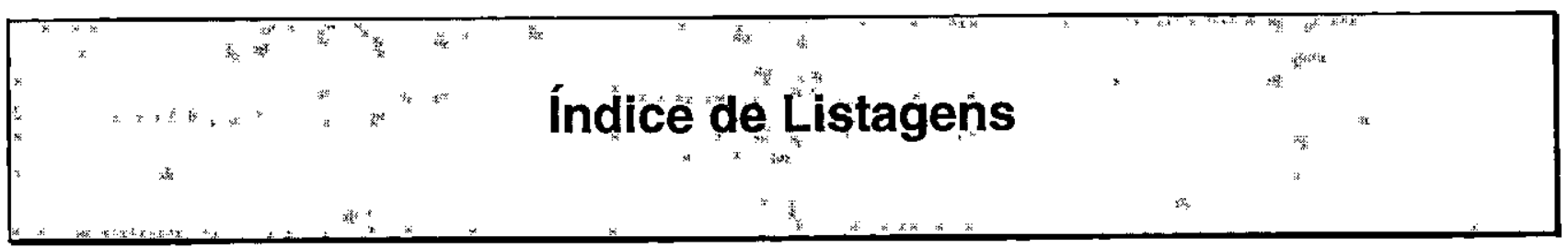

Listagem 2.1 - Exemplo de uma tabela default no VTK utilizando o modelo HSV 17

Listagem 2.2 - Exemplo de uma tabela personalizada no VTK utilizando o modelo RGB ...........................17

Listagem 2.3 - Exemplo de um mapeamento de cores e opacidades utilizando funçōes de transferência ... 18

Listagem 4.1 - Exemplo de um documento HTML referenciando uma animação MPEG............................. 42

Listagem 4.2 - Exemplo de um documento HTML contendo um formulário ................................................. 43

Listagem 4.3 - Exemplo de um script CGI usando $C_{++}$e VTK ....................................................................45 45

Listagem 4.4 - Exemplo de um script CGI usando C++ e VTK (Continuação) ............................................... 45

Listagem 4.5 - Exemplo de um script CGI usando C++ e VTK (Continuação) .............................................. 45

Listagem 4.6 - Exemplo de um documento HTML referenciando uma applet que faz uso do VTK .............. 47

Listagem 4.7 - Exemplo de uma applet Java com VTK................................................................................ 47

Listagem 4.8 - Exemplo de uma applet Java com VTK (Continuação) ......................................................... 48

Listagem 4.9 - Exemplo de uma applet Java com VTK (Continuaçăo) ....................................................... 48

Listagem 4.10 - Exemplo de uma applet Java com VTK (Continuação) ....................................................... 49

Listagem 4.11 - Exemplo de uma applet que utiliza Java 3D.....................................................................51

Listagem 5.1 - Exemplo de criação de um arquivo JAR..............................................................................58

Listagem 5.2 - Exemplo de um arquivo de políticas.....................................................................................61 61

Listagem 5.3 - Exemplo da sintaxe básica da ferramenta keytool ................................................................63

Listagem 5.4 - Exemplo da sintaxe da ferramenta javac............................................................................ 64

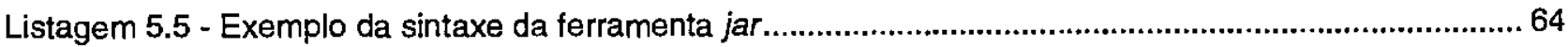

Listagem 5.6 - Exemplo da sintaxe da ferramenta jarsigner .......................................................................... 64

Listagem 5.7 - Exemplo da sintaxe da ferramenta keytool para exportar um certificado ..............................65

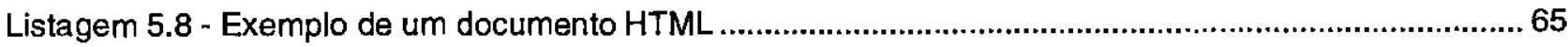

Listagem 5.9 - Exemplo de um documento HTML convertido..................................................................... 66

Listagem 5.10 - Exemplo da sintaxe da ferramenta keytool para importar um certificado ............................. 67

Listagem 5.11 - Exemplo da sintaxe da ferramenta keytool para exibir informações de um certificado ........ 67

Listagem 5.12 - Exemplo da sintaxe da ferramenta keytool para exibir informaçōes do keystore................. 68

Listagem 5.13 - Exemplo da sintaxe da ferramenta jarsigner para verificar a assinatura de um JAR ........... 68

Listagem 6.1 - Exemplo de configuração da variável de ambiente CLASSPATH ..........................................8 87

Listagem 6.2 - Exemplo de uma applet Java............................................................................................... 89

Listagem A.1 - Exemplo de uma applet Java para visualização de isosuperfícies ........................................ A.2

Listagem A.2 - Exemplo de uma applet Java que aplica um corte sobre uma isosuperfície ........................ A.4

Listagem A.3 - Exemplo de uma applet Java para visualização de volumes...............................................A.6

Listagem A.4 - Exemplo de um método em Java para conversão de dados escalares ..............................A.7

Listagem A.5 - Exemplo de uma applet Java para visualização de sub-volumes ..........................................9 
Listagem A.6 - Exemplo de uma applet Java para visualização de campos vetoriais.

A. 12 


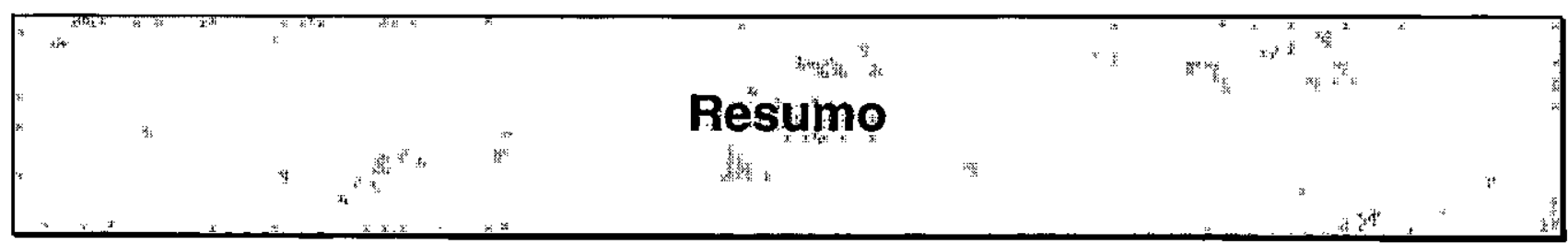

Este trabalho descreve um servidor que suporta visualização interativa na Internet por meio de applets Java que interfaceiam com o Visualization Toolkit. Como parte da revisão bibliográfica, são discutidas algumas abordagens para fornecer recursos de visualização na WWW explorando as tecnologias disponíveis para programação de aplicações baseadas na Web. Esse estudo foi fundamental para o desenvolvimento do servidor, denominado VisWeb, que oferece um arcabouço genérico para disponibilizar recursos de visualização de alta qualidade na WWW. O VisWeb é composto por três módulos para visualização volumétrica: um módulo de extração de superfícies, um módulo para rendering volumétrico direto e um módulo de visualização de campos vetoriais. Cada módulo é uma applet que implementa uma técnica de visualização, e permite a definição interativa e o controle local de parâmetros da visualização, além de oferecer recursos para a manipulação direta dos modelos gerados. Para garantir às applets o acesso a recursos locais foram estudados os mecanismos de segurança de Java. Também são discutidos alguns trabalhos descritos na literatura que oferecem recursos de visualização na Web, destacando as vantagens e limitações do VisWeb em relação a esses trabalhos. 


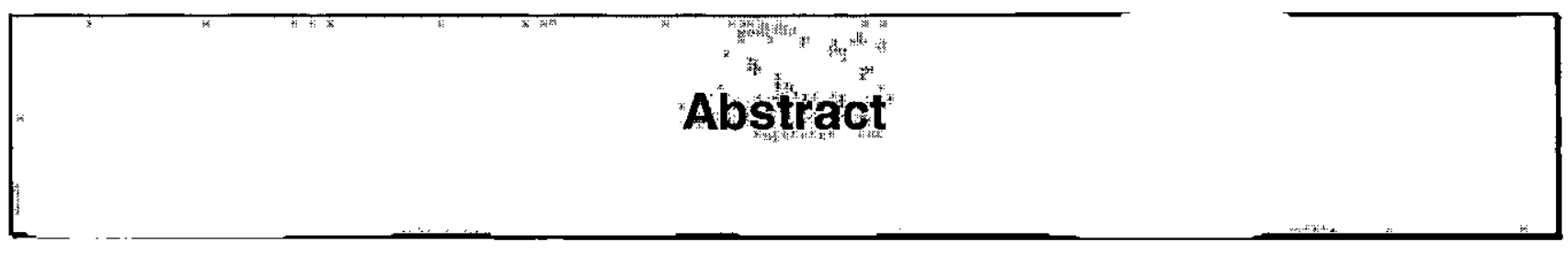

This work describes the development and implementation of a visualization server that supports interactive data visualization at the Internet. It is based on Java applets that interface with the Visualization Toolkit. Available technologies for programming Web-based applications that may be exploited to provide visualization functionality over the WWW are reviewed. The system developed, called VisWeb, offers a general framework for providing high quality volume visualization resources. It consists of three modules: a surface extraction module, a direct volume rendering module, and a glyph-based vector visualization module. Each of these is an applet that implements a visualization technique, and allows users to interactively define visualization parameters and to directly manipulate the models created. Because the applets must access local (client-based) resources, a study of security mechanisms in Java has also been conducted. Finally, a survey of related work on Web-based visualization is presented, and the advantages and limitations of VisWeb in relation to such work are discussed. 


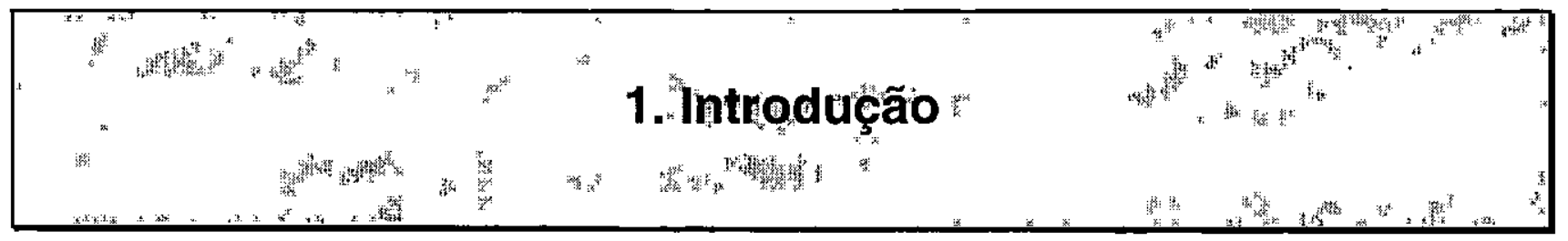

\subsection{Considerações iniciais}

O aumento do poder computacional e o desenvolvimento de técnicas mais avançadas de simulação criaram uma demanda de várias áreas de pesquisa por ferramentas gráficas e de auxílio computacional capazes de apoiar o processo de interpretação das informações geradas. A tradução de dados e informações para um formato gráfico é denominada Visualização. Muitas áreas de atuação humana que envolvem computação têm sido beneficiadas com a produção de visualizações, particularmente a área científica. A aplicação de técnicas gráficas para ampliar a capacidade de interpretação de dados científicos é denominada Visualização Científica (ViSC - Visualization in Scientific Computing).

Com o avanço dessa área, o profissional de computação precisará familiarizar-se com os principais conceitos que permitirão sua atuação junto aos demais profissionais que possam fäzer uso das técnicas disponíveis em visualização. A característica multidisciplinar do assunto impõe um desafio para o seu aprendizado, mas ao mesmo tempo, torna-o particularmente interessante. A tendência é que ferramentas de visualização de dados passem a exercer um impacto real na vida diária das pessoas, particularmente as que atuam em pesquisa científica, engenharia, medicina e educação.

Assim como a Visualização, a World Wide Web (WWW), ou simplesmente Web, também experimentou uma evolução considerável nos últimos anos, tendo revolucionado a maneira como as pessoas acessam informaçōes. As informações agora podem ser continuamente atualizadas, garantindo o acesso a dados atualizados em tempo de consulta. Desse modo, a Web oferece uma nova mídia para a Visualização, permitindo a colaboração e interação entre pesquisadores situados em diferentes locais. Apesar do seu enorme potencial, essa mídia ainda não tem sido muito explorada, pois existem vários problemas práticos associados à disponibilização de recursos de visualização para acesso remoto através da $W e b$.

O Grupo de Computação Gráfica e Processamento de Imagens (CG \& PI) do ICMC vem trabalhando na área de Visualização e, nesse contexto, tem estabelecido colaborações com 
diferentes grupos de usuários que precisam de recursos de visualização. A proposta deste trabalho foi investigar a possibilidade de disponibilização de um servidor de visualização na Web voltado especificamente a um grupo de usuários com os quais o grupo tem interagido.

\subsection{Motivação}

Certamente a Visualização como disciplina é anterior à Web, mas o que esta última acrescenta é a possibilidade de pessoas em diferentes locais compartilharem informações de maneira rápida e eficiente. A colaboração e interação entre pesquisadores é um aspecto essencial da Visualização, e mais importante do que compartilhar imagens ou animações pré-gravadas é a possibilidade de interagir com as visualizações e modificá-las, se necessário. Entretanto, existem várias limitações que dificultam a colaboração entre pesquisadores trabalhando em diferentes locais.

Primeiramente, o conjunto de dados a ser visualizado, que pode ser bastante volumoso, precisa ser copiado ou enviado. Adicionalmente, o software de visualização deve estar disponível em todos os locais, o que pode ser impossível dependendo do hardware e dos recursos disponíveis. Pode ser que nem todos os colaboradores tenham a capacidade de memória e de processamento necessário para gerar as visualizações. Esse é um cenário denominado visualização no cliente (client side visualization), uma vez que todos os passos da visualização são executados nos locais de colaboração (os clientes). A outra opção seria gerar a visualização em um único local (o servidor) e disponibilizar as imagens (ou animações) resultantes para os demais (os clientes). Entretanto, essa solução implica em uma perda significativa da capacidade de interação, pois os colaboradores nos demais locais têm pouco controle sobre as imagens e animações geradas. Como a Web é, basicamente, um sistema cliente-servidor [Tan96], sua tecnologia permite a execução de visualizações combinadas no cliente e no servidor, garantindo as vantagens de ambas as abordagens.

Uma atração óbvia da Web é que os dados podem ser exibidos na forma gráfica: imagens, por exemplo, estão presentes na Web desde o seu começo. De fato, a comunidade científica tem sido rápida para explorar o potencial da Web para divulgação e apresentação de seus resultados. Os grupos de pesquisa agora são capazes de apresentar seus trabalhos como documentos multimídia, com imagens e animações dos resultados. Entretanto, essas imagens e animações são passivas, ou seja, a visualização é criada pelo editor e o observador meramente olha as figuras como se folheasse diretamente um livro, sendo que a Web oferece muito mais possibilidades. Há espaço para participação ativa do observador na maneira que o dado é visualizado, tornando assim a 
visualização na Web uma ferramenta de análise, e não apenas uma mera ferramenta para apresentação de resultados.

\subsection{Objetivos}

O Grupo de CG \& PI do ICMC vem trabalhando no estudo, implementação e melhoria de técnicas de visualização no contexto do projeto PowerVis [Min97]. Esse projeto visa a criação e implementação de técnicas multimodais de visualização para facilitar o uso das técnicas de mapeamento gráfico por usuários em potencial. Nesse contexto, colaborações estão em andamento com diferentes grupos de pesquisa que são usuários de visualização e que fornecem os dados utilizados para as pesquisas em desenvolvimento.

Um aspecto que está sendo investigado como parte do projeto PowerVis é a possibilidade de disponibilização de um servidor de visualização na $W e b$, garantindo um mecanismo rápido e eficiente de colaboração entre os pesquisadores que geram os dados, os que geram as visualizações e os que a utilizam posteriormente, que podem ou não ser os mesmos que geraram os dados. Este projeto de mestrado teve como objetivo investigar as opções existentes, em termos de arquitetura e de tecnologia, para disponibilizar uma versão desse servidor voltada especificamente para atender as necessidades de um grupo específico de usuários. Esse servidor, a princípio, seria disponibilizado para os pesquisadores do Grupo de Visão Cibernética do IFSC, liderado pelo Prof. Luciano de Fontoura Costa. Esse grupo já vem interagindo com o Grupo de CG \& PI, sendo que já foram identificadas algumas técnicas essenciais para a visualização dos dados gerados por eles (ver descrição na Seção 1.4). Para implementação dessas técnicas foi utilizado o VTK - Visualization Toolkit [Sch98], que oferece uma biblioteca de rotinas que executam funções gráficas 3D e de visualização, e que será melhor detalhado posteriormente.

O servidor desenvolvido, denominado VisWeb, está interfaceando com o VTK para implementar as técnicas de visualização, e oferece uma interface gráfica em Java para o usuário executar as visualizações desejadas. Dessa forma, permite a definição interativa e o controle local de parâmetros da visualização (por exemplo, o tipo de técnica a ser utilizada, o número de isosuperfícies a serem geradas e o valor das mesmas, a tabela de cores a ser adotada, a taxa de amostragem dos dados vetoriais etc.), além de recursos para a manipulação direta dos modelos gerados nas visualizações. 


\subsection{Domínio da aplicação}

O grupo de Visão Cibernética do IFSC é um dos grupos de usuários de visualização que tem interagido com o grupo de CG \& PI. Eles têm trabalhado intensamente na análise da forma de neurônios e estruturas neurais [Coe94, Coe95, Ces97], tendo gerado modelos artificiais realísticos de estruturas neurais com o objetivo tanto de simular sistemas naturais como de investigar novas arquiteturas e paradigmas em redes neurais artificiais. Particularmente, Coelho e Costa [Coe94, Coe95] sintetizam estruturas neurais usando gramáticas estocásticas que operam sobre uma série de regras de produção bem definidas, derivadas a partir de caracterizações estatísticas e fractais de diferentes tipos de neurônios.

Uma đas saídas geradas por essas gramáticas, com o objetivo específico de gerar uma representação gráfica para propósitos de visualização, consiste em uma descrição do neurônio na forma de uma poligonal bi ou tridimensional definida em um espaço discreto. Nesse espaço discreto, valores 0 ou 1 indicam a presença ou ausência do neurônio, respectivamente. Posteriormente, esses dados foram processados pela aplicação de uma Gaussiana, com o objetivo de estudar as interações entre os diferentes componentes dos neurônios. O resultado é um conjunto de valores escalares entre 0 e 1 , posicionados no espaço discreto. O campo magnético na região neuronal também pode ser simulado, o que resulta em um conjunto de dados vetoriais, também posicionados em urn espaço discreto.

Várias visualizações foram geradas a partir desses dados, utilizando o VTK. O objetivo das visualizações iniciais era exibir as formas dos neurônios depois da aplicação da Gaussiana, o que poderia fornecer subsídios para uma análise quantitativa dos resultados produzidos pela gramática de simulação. Inicialmente, os dados foram reformatados para o tipo de malha estruturada do VTK, de forma a permitir a aplicação de técnicas convencionais de extração de superfícies e de rendering volumétrico. Em ambos os casos foram utilizadas classes do VTK que implementam as técnicas conhecidas como marching cubes e ray casting, respectivamente, para extração de superfícies e rendering volumétrico direto. Assim, a partir da descrição do neurônio no espaço discreto foi gerada uma malha regular, sendo que nos pontos introduzidos para tornar a malha regular foi inserido um valor inválido, no caso 2 (sabe-se que valores "válidos" estão no intervalo [0,1]).

Algumas visualizações obtidas para dois conjuntos de dados escalares distintos são mostradas nas figuras 1.1 e 1.2. A Figura 1.1 ilustra visualizações geradas por extração de superfícies, e a Figura 
1.2 ilustra visualizações obtidas por rendering volumétrico direto. O processo de geração dessas visualizações é descrito em Minghim et al. e em Costa et al. [Min98, Cos00].

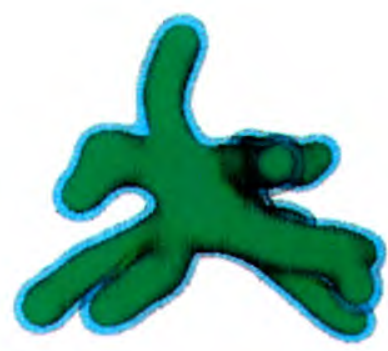

(a)

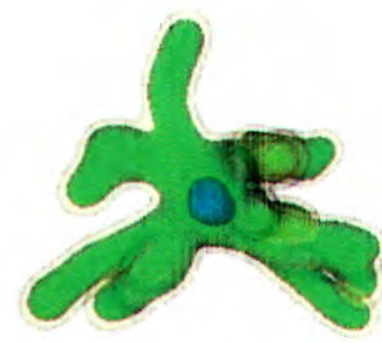

(b)

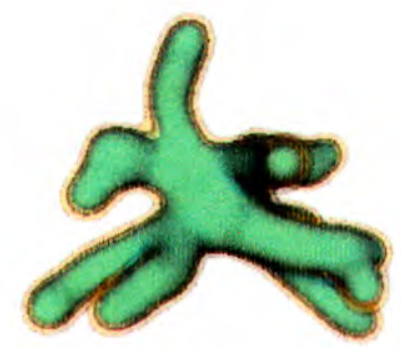

(c)

Figura 1.1 - Neurônios visualizados por extração de superfícies

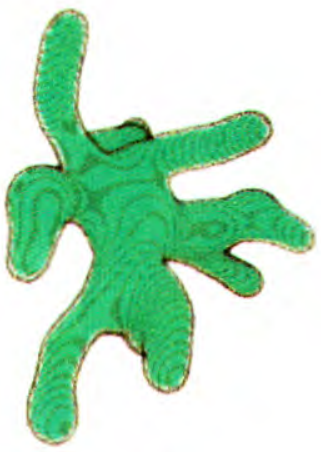

(a)

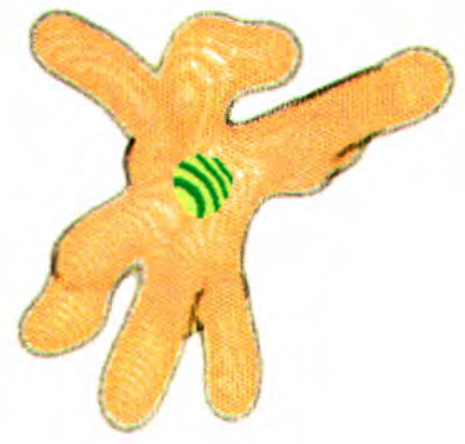

(b)

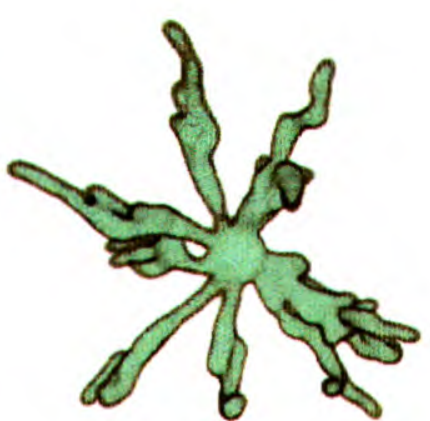

(c)

(a) e (b) Visualizações Volumétricas do conjunto de dados da Figura 1.1

(c) Visualização volumétrica de outro conjunto de dados

Figura 1.2 - Visualização volumétrica dos dados de neurônios

A Figura 1.3 apresenta algumas visualizações obtidas a partir dos conjuntos de dados vetoriais. Esses são exemplos típicos, mas não excludentes, dos tipos de visualizações requeridas por esse grupo de "clientes". Outras visualizações poderiam ser geradas, por exemplo, usando linhas de escoamento (streamlines e variações), no caso dos dados vetoriais. 


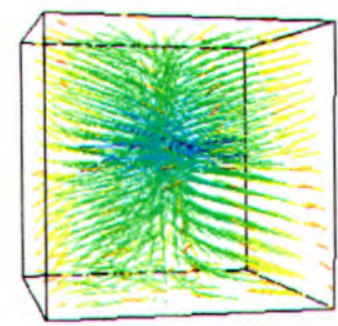

(a)

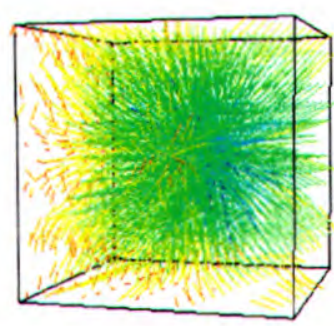

(b)

Figura 1.3 - Visualização do campo vetorial em torno de um neurônio

O objetivo desse projeto era disponibilizar um servidor (VisWeb) que incluísse as técnicas utilizadas para gerar esses tipos de visualizações: extração de superfícies, rendering volumétrico direto e visualização de vetores. Ressalta-se, entretanto, que o VisWeb (descrito no Capítulo 6) é genérico e pode, portanto, ser usado para aplicar as técnicas disponíveis a qualquer conjunto de dados escalares ou vetoriais descritos em uma malha regular (implementada no VTK pela classe vtkStructuredPoints). As figuras apresentadas neste Capítulo foram geradas no próprio VisWeb a partir de diferentes conjuntos de dados que descrevem modelos de neurônios, mas no Capítulo 6 são apresentadas visualizações de conjuntos de dados em outros domínios da aplicação.

\subsection{Organização}

Esta dissertação está organizada da seguinte maneira: no Capítulo 2 são apresentadas técnicas clássicas de visualização volumétrica, com ênfase nas técnicas utilizadas no trabalho desenvolvido; e também técnicas clássicas de visualização vetorial. No Capítulo 3 são apresentadas as características dos principais recursos de programação disponíveis para a Web. No Capítulo 4 são analisadas algumas tecnologias importantes para garantir interação com um cliente de visualização via Web. No Capítulo 5 é apresentado um estudo sobre segurança em Java, destacando como criar e usar uma assinatura digital para assinar os módulos do VisWeb. No Capítulo 6 é apresentado o VisWeb, ilustrando todas as suas funcionalidades e o procedimento necessário para acessá-lo pela Web. No Capítulo 7 são discutidas algumas ferramentas de visualização de dados na Web e, finalmente, no Capítulo 8 são apresentadas as conclusões e trabalhos futuros. 


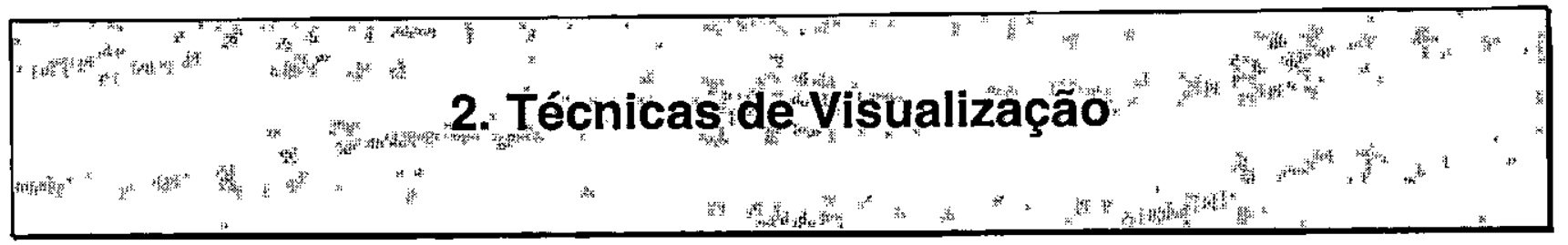

\subsection{Considerações iniciais}

Muitas técnicas têm sido desenvolvidas para apoiar a apresentação e a interação com dados de todos os tipos, incluindo representações lineares, bidimensionais (2D) e tridimensionais (3D), e definições particulares de formas, cores e abstrações para a exploração e localização de aspectos importantes de dados. Nesse contexto, a Visualização estuda estratégias e algoritmos para mapear informações (numéricas, no caso da ViSC) em representações gráficas.

Este Capítulo apresenta algumas dessas estratégias, concentrando-se em técnicas de visualização de dados escalares e vetoriais. Na Seção 2.2 são apresentados alguns conceitos em Visualização que são relevantes para o trabalho a ser desenvolvido. Na Seção 2.3 é apresentada uma visão geral da biblioteca VTK, que foi utilizada no desenvolvimento do VisWeb para implementar as técnicas de visualização. Na Seção 2.4 são abordadas técnicas de visualização de dados escalares definidos sobre domínios volumétricos. Na Seção 2.5 são desccritas técnicas clássicas de visualização vetorial, e na Seção 2.6 é descrita a técnica de mapeamento por cores.

\subsection{Visualização Computacional}

A motivação para o desenvolvimento da área de Visualização Computacional é a grande quantidade de informações disponíveis atualmente para serem interpretadas, e a escassez de tempo e de recursos humanos para fazê-lo. Essa grande quantidade de dados é devida ao aumento da capacidade de medição e processamento alcançado com o avanço da tecnologia. A tradução de dados e informações para um formato gráfico utilizando o computador, denominada Visualização Computacional, é essencial para que se consiga processar os dados tão rapidamente quanto necessário, sendo que a consequiência imediata é o aumento de produtividade [Min97a].

Exisstem várias definições de visualização. Brodlie et al. [Bro92] definem a Visualização Científica (ViSC) como uma área preocupada com a exploração de dados e informações de maneira a proporcionar entendimento sobre os dados e os fenômenos que os geram. McCormick et al. [McC87] definem visualização como um conjunto de métodos da computação que transforma 
entidades simbólicas em entidades geométricas, permitindo aos pesquisadores observarem os resultados de suas simulações e computações. Eles afirmam, ainda, que a visualização enriquece o processo de descoberta científica, e pode promover esclarecimentos profundos e inesperados sobre os fenômenos em estudo. A área de Visualização pode ser classificada em três sub-áreas, a saber:

$>$ Visualização Científica: abrange a visualização de dados medidos e simulados em experimentos científicos e de engenharia. Normalmente, esses dados possuem uma geometria implícita e intuitiva associada e representam fenômenos físicos, biológicos ou químicos. Uma sub-área da ViSC é a Visualização Volumétrica, que envolve a representação, manipulação e rendering de modelos gráficos gerados a partir de conjuntos de dados volumétricos.

Visualização de Software: é um ramo particular da visualização que estuda ferramentas visuais de auxílio às várias tarefas de desenvolvimento de programas e sistemas, incluindo apoio ao desenvolvimento, depuração, análise, e verificação de software. Devido aos requisitos particulares dessa sub-área, ela tem sido tratada separadamente das demais aplicações em visualização de dados.

Visualização de Informação: engloba o desenvolvimento de técnicas de visualização de dados que não possuem geometria intrínseca ou natureza gráfica. Normalmente, referese à representação gráfica de dados complexos, multidimensionais e volumosos, como hierarquias muito grandes, bases de dados, dados obtidos em levantamentos estatísticos, dados financeiros etc.

Uma técnica de visualização envolve vários passos: a construção de um modelo empírico a partir dos dados; a seleção de algum mecanismo de mapeamento do modelo em um objeto de visualização abstrato, como uma imagem ou um mapa de contornos; e o rendering da imagem no dispositivo gráfico. O rendering é o passo que recorre às técnicas e algoritmos da Computação Gráfica (CG). Rendering é o processo de geração de uma imagem a partir de uma descrição computacional de uma cena composta por um ou mais modelos. Esse processo varia enormemente, e muitas técnicas estão disponíveis para sua realização, envolvendo desde a geração de desenhos em duas dimensões até técnicas sofisticadas de geração de imagens 3D. Ao contrário da CG, entretanto, em ViSC muitas vezes não é necessário recorrer a técnicas sofisticadas de rendering, pois o requisito principal é que as imagens sejam significativas, e não que sejam "fotorealistas". A Visualização envolve, portanto, a exploração, transformação e mapeamento de dados em objetos gráficos. 
A complexidade dos dados e a dificuldade de mapeá-los graficamente para dispositivos 2D são fortes obstáculos ao uso de técnicas de visualização. Outro problema relacionado ao uso das atuais técnicas e sistemas de visualização é a falta de orientação aos usuários durante o processo de mapear atributos dos dados em representações visuais. A complexidade dos dados e a grande variedade de representações visuais existentes dificultam a criação de uma visualização efetiva, ou seja, a criação de imagens que realmente ajudem a analisar o fenômeno representado pelos dados.

\subsubsection{O processo de visualização}

Os sistemas de visualização devem ser usados como parte integrante do processo de investigação científica. Ao investigar um fenômeno, os especialistas em um certo domínio do conhecimento estão, normalmente, tentando encontrar um modelo que explique os dados empíricos obtidos do "mundo real". Desse modo, o processo de investigação requer a criação de um modelo empírico da "realidade", a aquisição de dados que sirvam como subsídios para verificar ou refinar o modelo, e o uso desse modelo para fazer previsões. No ciclo de investigação, o cientista usa o seu discernimento e conhecimento (insight) sobre o fenômeno para formular uma hipótese, coletar dados, controlar um processo de computação, visualizar e interpretar os resultados e, em seguida, repetir e refinar o ciclo, como ilustrado na Figura 2.1.

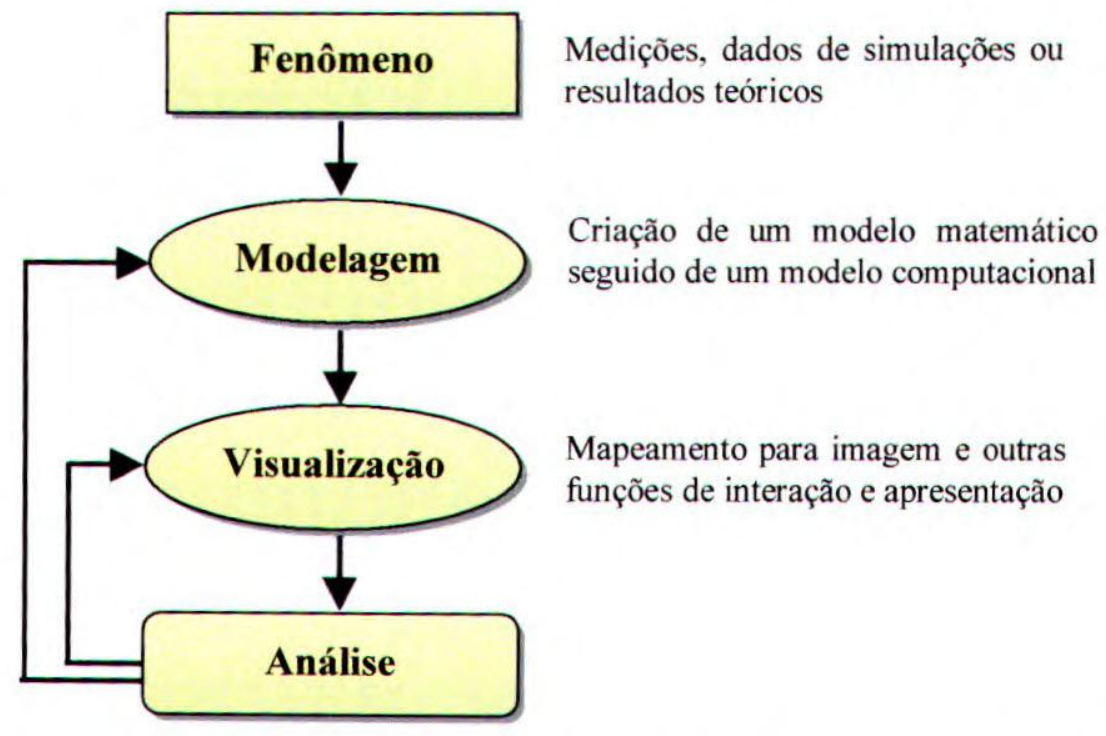

Figura 2.1 - Análise científica e feedback com o auxílio da visualização [Min97a]

Os sistemas de visualização também devem ser caracterizados por um procedimento interativo iniciado pelo usuário, que continua o processo de investigação à medida que recebe feedback do sistema. A interação é realizada pelo usuário, através da interface ao qual é apresentado, é transformada logicamente de volta aos termos do fenômeno científico sob investigação, e resultados 
atualizados são gerados pelo sistema de visualização e apresentados ao usuário. Dessa forma, o usuário aumenta o seu conhecimento sobre a validade da hipótese originalmente formulada e sobre o modelo adotado para a sua investigação [Min97a].

Os dados podem ser obtidos de duas maneiras: medições experimentais pela amostragem de processos empíricos, ou simulações computacionais. A consequiência é que os dados são conhecidos apenas em pontos discretos. Isso cria um sério problema, pois uma das atividades relevantes em visualização é justamente determinar valores dos dados em pontos arbitrários. Outro problema típico do processo de visualização é que os dados de entrada, geralmente, contêm erros aleatórios introduzidos pelo próprio processo de aquisição. Os dados precisam ser "filtrados" para que o erro seja removido, mas o processo de filtragem pode "distorcê-los", removendo características de interesse ou incluindo informações espúrias. Finalmente, os processos experimentais podem ser conduzidos erradamente, gerando dados errados. Esses problemas refletem-se como limitações a serem tratadas também nas técnicas e sistemas de visualização.

\subsubsection{Tipos de dados}

Os dados em ViSC podem ser definidos sobre domínios 2D, 3D e, genericamente, multidimensionais. Geralmente, um conjunto de dados possui uma certa organização: normalmente, consiste de uma malha (ou grade) de células, sendo que os dados estão posicionados nos vértices de cada célula, e valores no interior das células podem ser obtidos por interpolação. Entretanto, os dados também podem se constituir de um conjunto de pontos esparsos. Além disso, as informações associadas a cada ponto da malha podem ser um ou mais valores escalares, vetoriais ou tensoriais [Min97a]. A Figura 2.2 ilustra uma malha volumétrica. A malha volumétrica pode se constituir por voxels ou células.

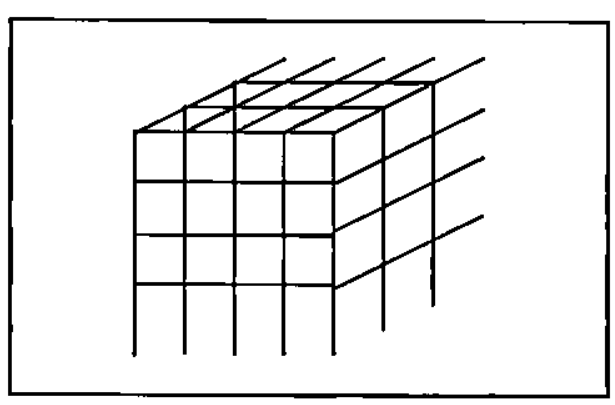

Figura 2.2 - Malha volumétrica

O voxel é um elemento de volume unitário, correspondente 3D do pixel, sendo que um único dado é armazenado no seu interior. A célula também é um elemento de volume unitário, porém os dados 
estão posicionados nos seus vértices, e valores dos dados posicionados no seu interior podem ser obtidos por interpolação dos valores nos vértices.

Um conjunto de dados consiste de duas partes: uma estrutura de organização e atributos de dados complementares associados à estrutura. A estrutura tem duas partes: uma topologia e uma geometria. A topologia é um conjunto de propriedades invariantes sob certas transformações geométricas (como rotação e translação). A geometria é a instanciação da topologia, ou seja, a especificação da posição no espaço 3D. Por exemplo, quando declaramos que um polígono é um "triângulo", estamos especificando a topologia. E quando fornecemos as coordenadas dos pontos, estamos especificando a geometria. Os atributos, por sua vez, são informações complementares que podem estar associadas tanto à geometria quanto à topologia [Sch98].

Assim, a estrutura de um conjunto de dados está implicitamente definida por pontos (que associam informação geométrica aos itens de dados) e células (que associam propriedades topológicas). Os dados propriamente ditos são atributos associados aos elementos (pontos e células) dessa estrutura. De acordo com a organização definida pela estrutura, pode-se tratar vários tipos de malhas, exemplificadas na Figura 2.3, segundo a nomenclatura de Elvins [Elv92].

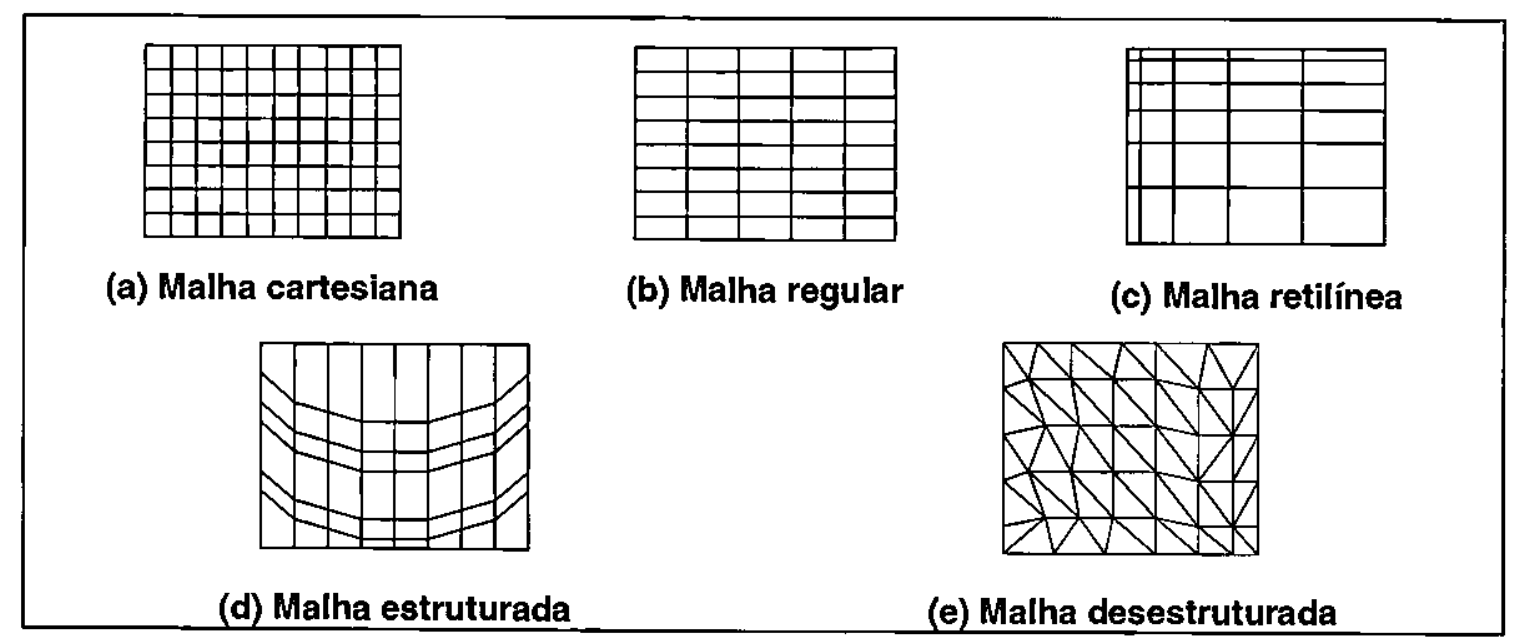

Figura 2.3 - Diferentes tipos de malhas

A principal distinção é que conjuntos de dados podem ser regulares (estruturados), ou irregulares (desestruturados). Um conjunto é regular se existe um relacionamento matemático regendo a disposição de pontos e células. Se a malha de dados apresenta regularidade, a sua natureza sugere a sua descrição em um sistema cartesiano, no qual pontos e células podem ser indexados facilmente. Uma malha completamente regular apresenta um relacionamento inerente entre os pontos aos quais estão associados os dados. Com isso, não é necessário armazenar explicitamente as posições de 
todos os pontos. Por outro lado, uma malha irregular deve ter seus pontos representados explicitamente, pois não apresenta um padrão que possa descrevê-la resumidamente. Entretanto, malhas irregulares têm a vantagem de serem mais flexíveis e de permitir representações adaptativas (com mais células nas regiões nas quais a informação é mais densa).

Desse modo, o problema fundamental na visualização de dados é encontrar uma representação gráfica para conjuntos de dados que reflita o seu conteúdo e significado. Tal tarefa possui aspectos que dependem da classe de aplicações para a qual uma técnica específica é utilizada. Na próxima Seção é apresentada a biblioteca VTK e nas Seções seguintes são apresentadas as principais técnicas de visualização de dados científicos, concentrando-se em Visualização Volumétrica.

\subsection{O Visualization Toolkit}

O VTK é uma biblioteca (orientada a objetos) de classes de objetos gráficos e de visualização, de baixo custo, e que tem a vantagem de ser extensível. Por ser uma biblioteca de classes, o software não inclui uma interface gráfica com o usuário. Ele foi escrito em $\mathrm{C}++$, e as suas classes podem ser acessadas por programas escritos em $\mathrm{C}++, \mathrm{Tcl} / \mathrm{Tk}$ ou Java [Sch98].

Usando o paradigma de orientação a objetos, o VTK define classes de entidades, às quais são atribuídos um significado, atributos e métodos. O significado representa o papel que a entidade desempenha no funcionamento do sistema; os atributos são propriedades ou parâmetros das entidades, e os métodos alteram os atributos e determinam a execução de ações. A biblioteca contém classes que permitem representar as principais organizações de conjuntos de dados e algoritmos de visualização discutidos nas Seções seguintes.

No contexto de visualização de dados, o VTK possui a capacidade de especificar um modelo funcional chamado de Pipeline de Visualização ou Rede de Visualização. O pipeline consiste de objetos para representar os dados, objetos para realizar operações sobre os dados e uma direção de indicação do fluxo de dados (conexões com setas entre os objetos), conforme ilustra a Figura 2.4. Os elementos de um pipeline incluem três tipos de objetos:

Fontes: fazem a leitura de conjuntos de dados, ou geram pontos a partir da amostragem de funções implícitas. Uma fonte é caracterizada por não ter nenhuma entrada e por produzir pelo menos uma saída; 
Filtros: extraem informações e geram dados a partir de outros dados. Um filtro é caracterizado por ter pelo menos uma entrada e por produzir pelo menos uma saída;

> Mapeadores: representam a parte final do fluxo de visualização, sendo usados para converter dados em primitivas gráficas ou escrever gráficos em arquivos. Um mapeador é caracterizado por ter pelo menos uma entrada e por não produzir nenhuma saída.

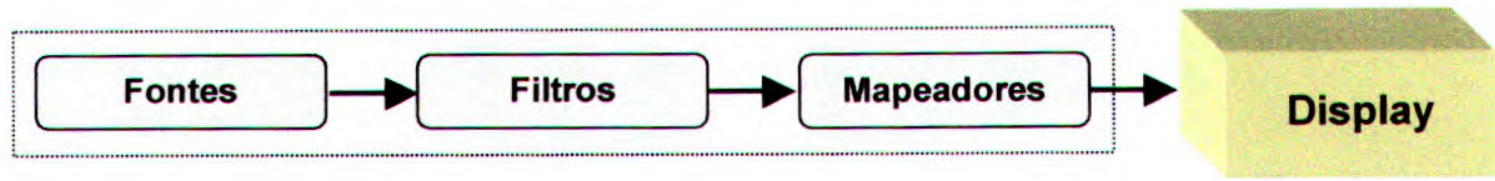

Figura 2.4 - Conexão entre Fontes, Filtros e Mapeadores

O trabalho de construção desses pipelines não é suportado por uma interface gráfica. Na verdade, o usuário deve ter em mente o pipeline de visualização que deseja usar, e programá-lo em alguma linguagem (C++, Tcl/Tk ou Java). No Apêndice são apresentados os pipelines de visualização do VTK, escritos em Java, implementados no VisWeb.

A escolha do VTK para implementar as técnicas de visualização oferecidas no VisWeb, deve-se ao fato de se tratar de um código aberto, de baixo custo, que interfaceia com Java e com versões para plataformas Windows e Linux.

\subsection{Técnicas de Visualização Volumétrica}

As técnicas de Visualização Volumétrica são, geralmente, classificadas como baseadas em superfícies ou em rendering volumétrico direto [Elv92, Kau93].

As técnicas baseadas em superfícies extraem isosuperfícies de valor constante dentro do volume. Essa abordagem consiste em aplicar um detector de superfícies ao volume de pontos amostrados e, em seguida, ajustar primitivas geométricas sobre superfícies detectadas, as quais são posteriormente renderizadas por técnicas tradicionais da CG. Um algoritmo clássico que se enquadra nessa classe é o marching cubes [Lor87]. Uma vantagem das isosuperfícies é a possibilidade de identificação de estruturas nos processos de medições ou simulações. Elas também permitem análise em tempo real pois, apesar do processo de extração das superfícies ser lento, o rendering das superfícies resultantes pode ser muito rápido se feito por hardware. Entre as desvantagens, tem-se a perda da informação relativa ao conteúdo do conjunto de dados fora dos valores selecionados para o traçado. Além disso, nem sempre os dados podem ser descritos em termos de superfícies, como é o caso dos objetos amorfos (nuvens, fumaça etc.). A técnica de extração de superfícies é implementada no 
VTK pela classe $v t k C o n t o u r F i l t e r$, sendo que o seu uso em um pipeline de visualização é ilustrado no Apêndice (ver Figura A.1), que também ilustra algumas visualizações geradas com essa técnica (ver Figura A.2).

As técnicas de DVR (Direct Volume Rendering) permitem o rendering direto de conjuntos de dados 3D sem a geração de primitivas geométricas intermediárias, pois não trabalham com superfícies, mas com os valores armazenados nos voxels do volume. Elas permitem ao usuário enxergar "dentro" (ou "através") do volume de dados, possibilitando a visualização de mais informações do que as técnicas de rendering de superfícies. Essas técnicas podem ser agrupadas em duas categorias: as que operam no espaço do objeto, ou seja, os voxels são projetados diretamente no plano da imagem; e as que operam no espaço da imagem, isto é, pixel a pixel. O rendering volumétrico tem por objetivo visualizar a estrutura intema do volume de dados, sendo que para isso, é necessário trabalhar com transparência. Para isso, o usuário define uma tabela que mapeia valores de dados em cores, e uma tabela de opacidades que mapeia valores de interesse em coeficientes opacos, e valores de menor interesse em coeficientes transparentes. Algoritmos típicos dessa categoria são o ray casting e o splatting [Elv92, Sch98]. A técnica de ray casting é implementada no VTK pelas classes $v t k V o l u m e R a y C a s t C o m p o s i t e F u n c t i o n$ e $v t k V o l u m e R a y C a s t M a p p e r$, cujo uso em um pipeline de visualização é ilustrado no Apêndice (ver Figura A.5). Algumas visualizações geradas com essa técnica são apresentadas na Figura A.6.

\subsection{Técnicas de Visualização Vetorial}

É comum, principalmente em aplicaçōes que envolvem fluxo, que os dados sejam vetores definidos sobre pontos geométricos. Esses campos vetoriais podem ter duas, três ou mais dimensões, e podem estar definidos sobre regiões planares ou volumétricas. A visualização de campos vetoriais em uma tela bidimensional não é trivial. Uma opção consiste em extrair uma quantidade escalar do campo vetorial, e usar alguma técnica aplicável a campos escalares. Mas isso implica em uma séria perda de informações, o que motiva intensa pesquisa em estratégias adequadas para a visualização de campos vetoriais.

No meio científico, a representação mais tradicional e intuitiva para vetores é por setas, isto é, segmentos de reta orientados segundo a direção e sentido do vetor e, em geral, de comprimento proporcional à magnitude do mesmo. Genericamente, a técnica computacional envolve a escolha de uma quantidade de pontos representativos do domínio e a atribuição, a cada um deles, de um ícone puntual orientado, ou glyph, que indique a direção do campo vetorial no ponto (por exemplo, a 
velocidade local). Um "glyph" é um "objeto" cuja aparência é afetada por atributos de um dado de entrada ao qual está associado. Esse objeto pode ser uma entidade geométrica, um conjunto de dados, ou uma imagem gráfica. Muitas formas de glyphs e ícones teoricamente adequados para esse tipo de representação vêm sendo estudadas nos últimos anos [Sch98].

Entretanto, esse tipo de representação não se mostra muito eficiente, no caso 3D, por uma série de motivos. Em particular, ocorre um congestionamento visual quando os ícones (glyphs) se sobrepõem desorganizadamente devido à projeção na imagem bidimensional final, tornando impossível extrair a estrutura intrínseca do campo vetorial. Outro problema ocorre devido à ambigüidade da projeção final dos glyphs, pois, em geral, um segmento de reta projetado num plano pode corresponder a várias posições da mesma linha no espaço, gerando problemas de orientação. Apesar desses problemas, acredita-se que o uso de ícones puntuais não deve ser dispensado como uma estratégia prática e de baixo custo, que permite interatividade em tempo real, principalmente para campos 2D ou secções projetadas de campos 3D [Mar97]. Essa técnica é implementada no VTK pelas classes vtkMaskPoints, vtkVectorNorm e vtkHedgeHog, sendo que o seu uso em um pipeline de visualização, bem como algumas visualizações geradas, são ilustradas no Apêndice (ver Figuras A.10 e A.11).

Uma outra forma de representação é usar linhas de escoamento, que são curvas que representam a trajetória de partículas ou objetos. Uma de suas variações é a streamline, que pode ser construída escolhendo-se um ponto inicial e, em seguida, construindo segmentos de reta fazendo uma média dos vetores mais próximos. Pode-se, também, usar cores para indicar a magnitude da velocidade da partícula a cada ponto da streamline.

As linhas de escoamento são muito mais eficientes do que ícones puntuais para transmitir características gerais do escoamento, pois geram representações com menor congestionamento visual. Entretanto, os esquemas de interpolação e de integração numérica adotados introduzem erros de visualização e elevam o custo da visualização consideravelmente em relação a ícones puntuais, principalmente no caso 3D. Uma dificuldade comum às setas e streamlines é a densidade de informações apresentada ao observador [Mar97].

Uma outra estratégia para a visualização de campos vetoriais são os mapas de deslocamento (displacement plots). Essa estratégia permite visualizar deslocamentos na superfície de um objeto resultantes da ação de campos vetoriais, ilustrando o movimento de um objeto (por exemplo, uma placa retangular) na direção perpendicular à sua superfície. O movimento do objeto é causado pela 
aplicação de um campo vetorial, tipicamente, um deslocamento ou um campo de força. Os mapas de descolamento usam a idéia de "geração de escalares a partir dos vetores". Nesse caso, os vetores são convertidos para escalares calculando o produto escalar entre a normal à superfície e o vetor a cada ponto. Se o valor resultado for positivo, o movimento no ponto é na direção normal à superfície (isto é, um deslocamento positivo) e, se for negativo, indica que o movimento é no sentido contrário a normal à superfície. Uma aplicação útil dessa técnica é no estudo de vibrações. No Capítulo 4, é apresentado um exemplo de uso dessa técnica, para exibir alguns modos de vibração de uma placa retangular (ver Figura 4.8).

\subsection{Mapeamento por Cores}

O mapeamento por cores é uma técnica de visualização bastante utilizada em Visualização Científica, que consiste em associar dados escalares a cores, exibindo-as como indicação de valores [Min97a, Sch98]. Esse mapeamento pode ser implementado indexando uma tabela de cores (Lookup Table), sendo que os valores escalares são usados como índices para a tabela. Essa tabela é um vetor de cores (descritas em termos de seus componentes RGB), e está associada a um intervalo de variação (scalar range) definido por um valor mínimo e um valor máximo, e os valores escalares são mapeados nesse intervalo.

O ponto chave para a utilização de mapas de cores na visualização de dados escalares é a escolha adequada das cores que compõem a tabela, sendo que o uso cuidadoso de cores pode realçar características importantes de um conjunto de dados. Entretanto, uma tabela de cores inadequada pode destacar detalhes irrelevantes, ou mesmo criar artefatos visuais devido a interações inesperadas entre as cores, à escolha inadequada de cores e/ou à própria limitação do sistema visual humano [Sch98]. Esse tema é discutido em vários trabalhos [Oli98, Tut98, Pau00]. A técnica é aplicável a dados escalares definidos em domínios 1D, 2D ou 3D.

A classe vtkLookupTable do VTK define um objeto gráfico que permite estabelecer um mapeamento de valores escalares para cores ou de cores para valores escalares, gerando uma tabela de cores pela criação de instâncias da classe. Essas tabelas são definidas pela especificação de um número de entradas e de parâmetros de variação das cores. Os parâmetros podem ser definidos usando modelos HSV (hue-matiz, saturation-saturação, value-luminância) ou RGB (red-vermelho, green-verde, blue-azul). Pode-se, também, especificar ainda um valor de transparência (alpha), que varia de 0 a 1. Para gerar uma tabela utilizando o modelo HSV deve-se especificar o intervalo de variação de cada parâmetro, que pode variar de 0 a 1 ao longo de toda a tabela. As cores da mesma 
são definidas por uma função linear aplicada aos valores iniciais e finais dos componentes HSV e de transparência especificados. A geração de uma tabela default do VTK, usando a linguagem Java, pode ser feita como mostra a Listagem 2.1.

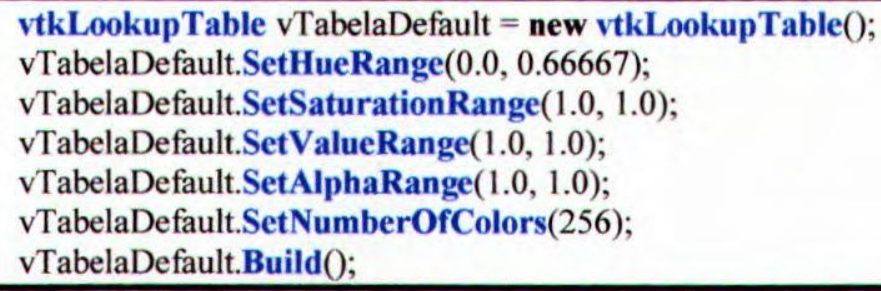

\section{Listagem 2.1 - Exemplo de uma tabela default no VTK utilizando o modelo HSV}

A geração de tabelas usando as primitivas do modelo RGB é feita especificando os componentes R, G, B de cada entrada da tabela individualmente. É necessário especificar o número de entradas da tabela, construí-la e, então, inserir os componentes R, G, B e a transparência de cada cor. Desse modo, é possível gerar tabelas personalizadas que não podem ser expressas como funções lineares de valores HSV. A Listagem 2.2 mostra a criação de uma tabela com três entradas, correspondendo às cores vermelha, verde e azul.

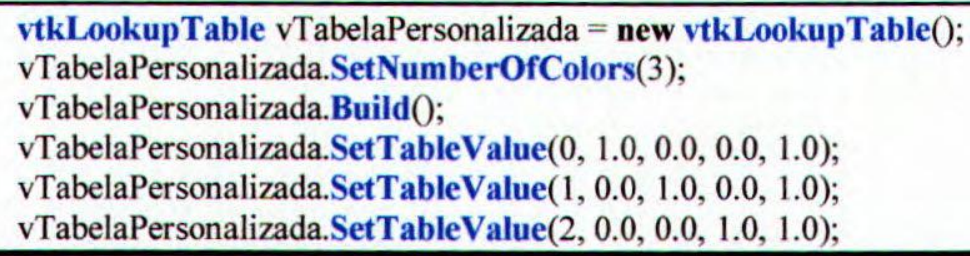

Listagem 2.2 - Exemplo de uma tabela personalizada no VTK utilizando o modelo RGB

Uma forma mais generalizada de tabela de cores é chamada de função de transferência, que é qualquer expressão que mapeia valores escalares em especificações de cores [Sch98]. Uma função de transferência é responsável por mapear intervalos de interesse dentro do conjunto de dados em cores, com a finalidade de produzir a imagem desejada. Funções utilizadas para mapeamento de cores e de opacidades, respectivamente, são representadas no VTK por instâncias das classes vtkColorTransferFunction e vtkPiecewiseFunction, conforme mostra a Listagem 2.3. 
vtkColorTransferFunction vFuncaoCores = new vtkColorTransferFunction();

vFuncaoCores.AddRGBSegment $(50,1.0,0.0,0.0,100,1.0,0.0,0.0)$;

vFuncaoCores.AddRGBSegment(120, 0.0, 0.0, 1.0, 210, 0.0, 0.0, 1.0);

vtkPiecewiseFunction vFuncaoOpacidades $=$ new vtkPiecewiseFunction();

vFuncaoOpacidades.AddSegment $(0,0.0,49,0.0)$;

vFuncaoOpacidades.AddSegment $(50,0.5,100,0.5)$;

vFuncaoOpacidades.AddSegment(101, 0.0, 119, 0.0);

vFuncaoOpacidades.AddSegment(120, 0.4, 210, 0.8);

vFuncaoOpacidades.AddSegment $(211,0.0,255,0.0)$;

Listagem 2.3 - Exemplo de um mapeamento de cores e opacidades utilizando funções de transferência

Esse código define dois intervalos de mapeamento em um conjunto de dados com escalares entre 0 e 255. O primeiro intervalo [50..100] é associado à cor vermelha e o segundo [120..210] é associado à cor azul. Em seguida, são definidos os intervalos de opacidade.

A técnica de mapeamento por cores pode ser utilizada tanto associada a técnicas de extração de superfícies quanto a técnicas de rendering volumétrico direto. Para extração de superfícies são utilizadas tabelas definidas com a classe vtkLookupTable (ver Listagens 2.1 e 2.2), e para o rendering volumétrico direto são utilizadas as classes vtkColorTransferFunction e vtkPiecewiseFunction (ver Listagem 2.3).

\subsection{Considerações finais}

A Visualização é uma área de pesquisa que tem evoluído muito rapidamente. No entanto, muitos problemas importantes ainda estão por ser resolvidos. Do ponto de vista dos conjuntos de dados, são necessárias estratégias para manipular conjuntos de dados cada vez maiores. Do ponto de vista de técnicas, é preciso desenvolver estratégias adequadas e efetivas para a visualização de informações altamente complexas e de natureza variada. Nesse contexto, foram apresentadas algumas abordagens clássicas para a visualização de dados escalares e vetoriais definidos em conjuntos volumétricos, as quais são relevantes para este trabalho. No próximo Capítulo são apresentados alguns recursos de programação disponíveis para a criação de aplicações distribuídas na $W e b$. 


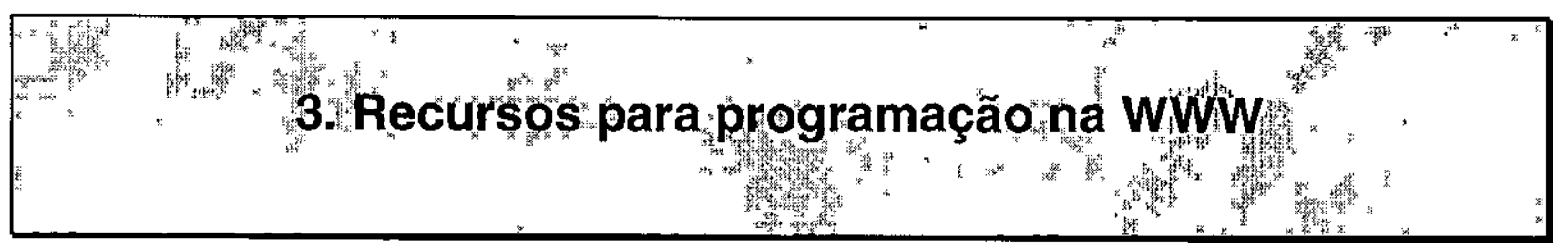

\subsection{Considerações iniciais}

A WWW, ao longo de sua existência, tem funcionado como um mecanismo passivo de divulgação de informações para uma população geograficamente distribuída. Mas, à medida que recursos de programação como bibliotecas multimídia e suporte interno de linguagens aos browsers tornam-se mais prontamente disponíveis aos usuários, estes passam a esperar mais de suas aplicações. Desde o surgimento da $W e b$, as expectativas dos usuários cresceram, e inúmeras ferramentas foram criadas para suportar a incorporação de recursos mais sofisticados aos sites.

Este Capítulo apresenta algumas dessas ferramentas, bem como os seus principais recursos, sendo que a escolha das tecnologias discutidas é baseada no seu interesse para o trabalho proposto neste projeto. Na Seção 3.2 é apresentado o CGI, que permite a criação de sites Web que incluem recursos de interação com o usuário. Na Seção 3.3 são apresentados os Servlets, um novo conjunto de aplicações escritas em Java. Na Seção 3.4 é apresentada a linguagem VRML, que tem obtido crescente aceitação como tecnologia padrão para a exibição de conteúdo gráfico tridimensional na Web. Na Seção 3.5 são comentadas as principais características da linguagem Java, principalmente em relação aos recursos para o desenvolvimento de applets para inserção em documentos HTML. Finalmente, na Seção 3.6 é apresentado o Java 3D, um complemento de Java que suporta a inclusão de recursos gráficos 3D em aplicações Java.

\section{2. $\mathrm{CGI}$}

O CGI, ou Common Gateway Interface, é um padrão que especifica o formato dos dados que browsers, servidores e programas usam para trocar informações [Jam97]. Existem alguns tipos de informações que não podem ser acessadas diretamente pelos browsers, como informações resultantes de acessos à base de dados e informações geradas dinamicamente. Tais informações não podem ser exibidas se não forem colocadas em um formato padrão reconhecível pelos browsers.

Os programas adicionais necessários para especificar ao servidor como acessar determinado tipo de informação solicitada pelo browser são denominados "scripts". E, por possibilitarem um caminho 
para a passagem de informação entre o browser e o servidor, são também chamados de "gateways". Desse modo, CGI é o padrão que possibilita a comunicação entre o servidor HTTP (HyperText Transfer Protocol) e os "scripts", sendo que o script CGI é um programa executado independentemente, escrito em qualquer linguagem aceita pelo servidor, seja ela compilada ou interpretada. As linguagens mais usadas são $\mathrm{C} / \mathrm{C}++$, Perl, Shell do Unix, Tcl/Tk, Visual Basic e Delphi [Gun96]. Um programa CGI é executado em tempo real, ou seja, no instante em que o cliente o solicita, através da sua URL (Uniform Resource Locator). Desse modo, o programa pode exibir informações dinâmicas (obtidas em tempo de execução), ao contrário de um documento puramente HTML, cujo conteúdo é estático.

\subsubsection{A ação de um programa CGI}

Um programa CGI não pode ser executado diretamente a partir do browser (cliente Web), é necessário localizar o script no servidor $W e b$. De forma resumida, a ação de um programa CGI ocorre da seguinte maneira, esquematizada na Figura 3.1.

1. o cliente solicita uma URL (que não é um documento HTML e sim um script) ao servidor;

2. o servidor, ao receber o formulário, utiliza a interface CGI para contatar o script e passar os dados fornecidos pelo cliente;

3. o programa CGI é executado no servidor com base nos valores de entrada do cliente (se houver). Essa execução pode envolver, por exemplo, pesquisa em um banco de dados através de outros programas;

4. o resultado da execução é enviado pelo script ao servidor via interface CGI;

5. o servidor envia o resultado do script ao cliente, acrescentando as informações de cabeçalho necessárias. 


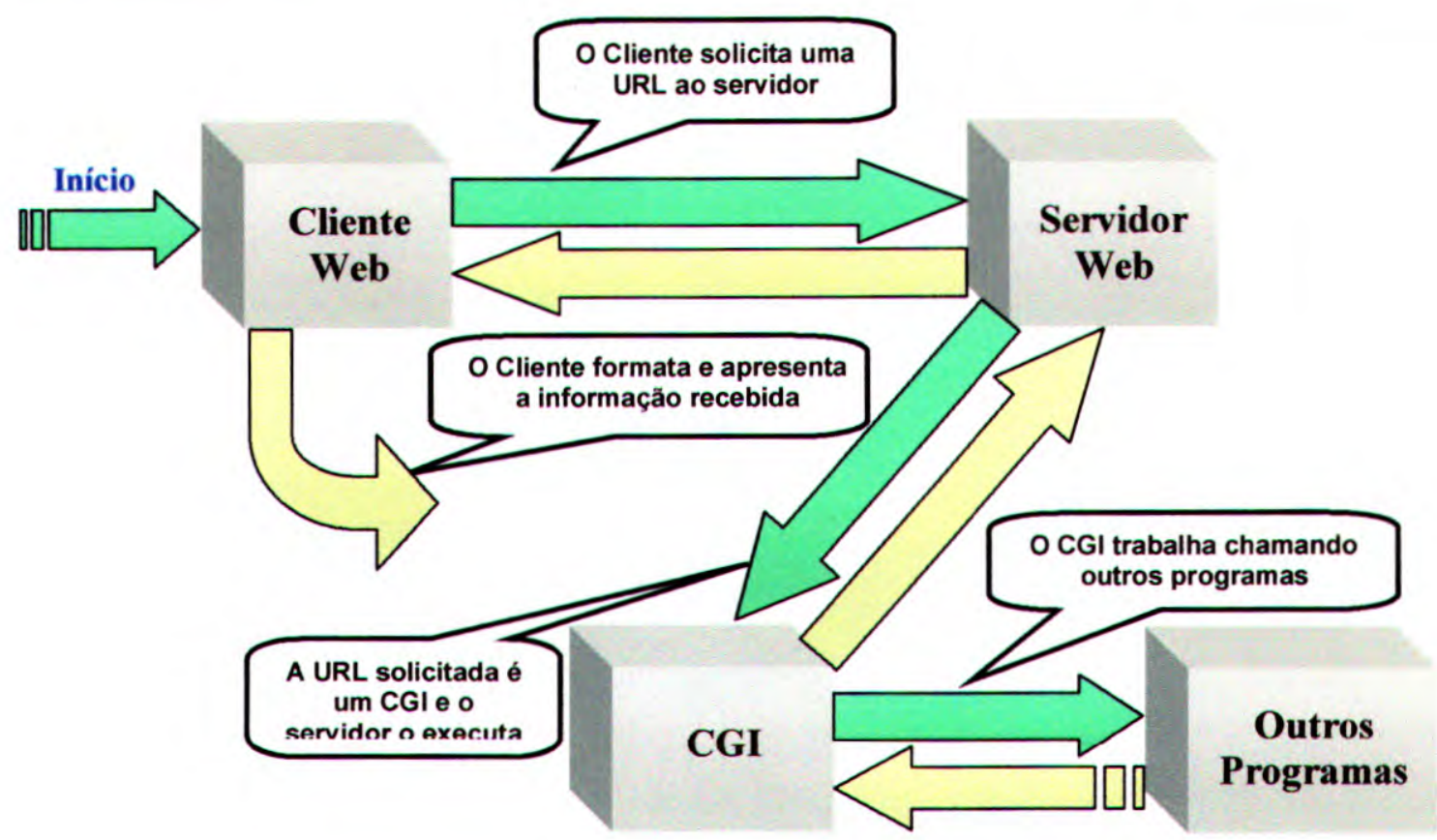

Figura 3.1 - Ação de um programa CGI

\subsubsection{A interface básica do CGI}

Quando um usuário da $W e b$ ativa uma ligação que faz o servidor carregar um script CGI, o servidor precisa configurar um conjunto de variáveis de ambiente utilizadas pelo script. Essas variáveis contêm informações sobre o browser que está fazendo a solicitação, sobre o servidor que está controlando a solicitação e sobre os dados (se houver) sendo passados ao script. A variável de ambiente CONTENT_LENGTH, por exemplo, determina o número exato de bytes contidos nos dados anexados [Blu96]. Quando o browser encaminha uma solicitação ao servidor (por exemplo, usando o método "POST" HTTP), as informações que o script CGI recebe vêm do descritor de arquivo stdin (standard input). Então, o valor da variável CONTENT_LENGTH determina a quantidade de dados a serem processados a partir de stdin. Além disso, o servidor fornece ao script CGI a variável de ambiente CONTENT_TYPE, que permite ao script decidir como controlar os dados a serem recebidos.

Os dados recebidos contêm uma seqüência de pares no formato name=value separados pelo caractere ' $\&$ '. A parte name contém o nome dos campos como definidos no documento HTML. A parte value contém os valores dos campos, ou seja, as informações entradas pelo usuário, fornecidas de forma codificada [Gun96]. A codificação é feita automaticamente pelo browser, e a decodificação deve ser feita pelo script CGI antes de utilizar os valores recebidos. 


\subsubsection{Formatando a saída do CGI}

A saída de um CGI tem, basicamente, duas partes: um cabeçalho e os dados de saída. O cabeçalho consiste em linhas de texto, no mesmo formato de um cabeçalho HTTP, e termina com uma linha em branco. É necessário enviar antes o cabeçalho para que o cliente conheça o tipo de informação a ser retornada pelo programa para tratá-la convenientemente. O cabeçalho não é visível ao usuário e serve para passar informações sobre a saída tanto ao servidor quanto ao cliente Web. Há três tipos de cabeçalhos [Jam97]:

$>$ Content-type

$>$ Location

$>$ Status

O campo Content-type identifica o tipo/subtipo MIME (Multipurpose Internet Mail Extensions) dos dados que o script está enviando de volta ao browser. Normalmente, os scripts CGI enviam um documento HTML. Nesse caso, o campo Content-type conteria o seguinte:

\section{Content-type: text/html}

O campo Location especifica um documento. Os scripts usam o campo Location para especificar ao servidor que chamou o script CGI que está retornando uma referência a um documento, e não o documento em si. Para especificar um documento remoto, por exemplo, o valor de Location poderia conter o seguinte:

\section{Location: http://www.jamsa.com/}

O campo Status contém um valor de HTTP que o servidor envia do script para o browser.

Os dados de saída são, realmente, a parte que será enviada ao cliente $W e b$, e seu conteúdo deve ser compatível com o tipo de conteúdo (Content-type) informado no cabeçalho.

\subsubsection{Vantagens e desvantagens}

A principal vantagem do uso de CGI é a sua simplicidade. Para o cliente, basta possuir um browser para, por exemplo, ter acesso a um banco de dados. Para o desenvolvedor, há a facilidade de escrever o código em qualquer linguagem, desde que esta possa ser compilada no servidor [Jam97]. Apesar de sua simplicidade, o CGI é inadequado para o desenvolvimento de sistemas complexos. 
Isso porque o script sempre é executado na máquina servidora, de modo que qualquer alteração nas aplicações requer uma intervenção do Webmaster, que precisa assegurar que o programa não vai causar danos ao sistema. Além disso, a execução do script no servidor pode representar uma grande sobrecarga para o sistema como um todo. Quanto mais trabalho puder ser distribuído nas máquinas clientes, maior será a eficiência da rede como um todo. Desse modo, conclui-se que o CGI deixa a desejar tanto em termos de desempenho, quanto em termos de segurança.

\subsection{Servlets}

A linguagem Java, devido às suas características (ver Seção 3.5), vem sendo cada vez mais utilizada para desenvolver aplicações a serem executadas stand-alone, independentes da Internet. Um novo conjunto de aplicação, os servlets, podem popularizar ainda mais a linguagem. Servlets são aplicativos escritos em Java que podem ser acoplados em diversos tipos de servidores para expandir as suas funcionalidades [Blo99]. Estes, ao contrário das applets, não possuem uma interface gráfica, e podem ser escritos para trabalhar com diversos tipos de protocolo de comunicação (por exemplo, HTTP).

\subsubsection{Funcionalidades}

Dentre algumas capacidades dos servlets que tornam esta tecnologia particularmente interessante, podemos citar [Col99]:

geração dinâmica de páginas HTML - os servlets podem ser instalados em servidores Web para processar informações transmitidas via HTTP a partir de formulários HTML, por exemplo. As aplicações podem incluir acesso a banco de dados ou comunicação com outros servlets;

balanceamento de carga entre servidores - para ilustrar como servlets podem ser usados para balancear carga, considere a infra-estrutura de um provedor de serviços via Internet composta de cinco servidores, dos quais quatro são capazes de executar as mesmas aplicações. O servidor restante poderia ficar responsável por monitorar as cargas dos demais e receber o acesso inicial de cada cliente às aplicações. Em seguida, poderia redirecionar os pedidos de acesso para um dos quatro servidores de aplicação, conforme a ocupação de cada um no momento em que o cliente tenta estabelecer uma conexão. Assim, o cliente passa a trocar informações somente com o servidor que foi alvo do redirecionamento; 
modularização do código: um servlet pode executar outro servlet, mesmo que remotamente, sendo possível executá-los em "corrente". Essa característica possibilita a modularização dos aplicativos, criando servlets com funções específicas. Suponha que, para acessar um conjunto de aplicativos, o cliente deva ser autenticado. Neste caso, uma configuração possível seria criar um servlet responsável apenas pela tarefa de autenticação. Uma vez autenticado o cliente, este servlet o redirecionaria para outro servlet, não necessariamente instalado no mesmo servidor, e que executaria o aplicativo. A vantagem deste tipo de arquitetura é que, se por alguma razão for necessário modificar o procedimento de autenticação, por exemplo pela mudança do banco de dados de usuários, não será necessário rescrever toda a aplicação, mas apenas o servlet responsável pelo processo de autenticação.

\subsubsection{Servlets versus CGIs}

Cada vez que um CGI é executado, é necessário carregá-lo na memória e iniciar um processo que será extinto com o término da execução do aplicativo [Co199]. Caso seja uma linguagem interpretada, como PERL, soma-se ainda o tempo necessário para interpretá-lo. Como esses são processos distintos, existe uma grande dificuldade no compartilhamento de recursos do sistema, por exemplo, conexão a um banco de dados e troca de informações entre os processos executados simultaneamente.

O servlet é carregado uma única vez na memória, aonde permanece até que seja necessário modificá-lo [Col99]. Normalmente, é necessário reiniciar o servidor toda vez que um servlet sofre alguma modificação. Entretanto, atualmente, alguns sistemas que executam servlets são capazes de recarregá-los sem a necessidade da reinicialização. Como os servlets permanecem na memória, é mais fácil desenvolver aplicações que exijam persistência entre conexões sucessivas de um mesmo cliente.

Uma vez inicializado, o servlet estará apto a lidar com centenas de acessos simultaneamente, disparando, para cada acesso, uma nova thread. As threads de um mesmo aplicativo utilizam um espaço de endereçamento de memória comum a todas, o que permite que elas compartilhem dados e recursos do sistema. Por exemplo, todas as threads de um servlet podem usar uma única conexão estabelecida com um banco de dados no momento da inicialização do servlet. Esta conexão permanece aberta até que o servlet seja desativado, saia da memória, ou seja recarregado. 
Como os CGIs são executados em processos distintos para cada acesso do usuário, esta persistência de estado é mais difícil de ser feita, pois ao final do processamento do CGI os seus dados são apagados da memória. Algumas alternativas seriam: utilizar arquivos temporários para armazenar o estado de cada cliente, ou mapeamento de memória compartilhada entre os CGIs. Entretanto, isso onera ainda mais o desempenho, pois exige operações explícitas de escrita e leitura em arquivos e acesso direto à memória, o que reduz a portabilidade entre sistemas operacionais, mesmo no caso de CGIs desenvolvidos em linguagens interpretadas.

Uma vez que os servlets são escritos em Java, uma linguagem projetada para ser independente de plataforma, é possível escrever um servlet para um servidor UNIX, que poderá ser instalado em um servidor Windows NT, sem a necessidade de rescrever o código, ou recompilá-lo. A orientação a objetos, uma das características de Java, favorece a modularização dos aplicativos, o que os torna mais escaláveis.

\subsection{VRML}

A Realidade Virtual pode ser considerada como um conjunto de técnicas e ferramentas gráficas 3D que permite aos usuários interagir dentro de um ambiente gerado por computador [Net98]. Da idéia de levar a "Realidade Virtual" para a Internet surgiu a VRML, que é a abreviação de Virtual Reality Modeling Language [Ame96]. A VRML é uma linguagem textual destinada à construção de ambientes virtuais nos quais pode-se passear, visualizar objetos sob ângulos diferentes e com os quais pode-se interagir. A primeira versão da linguagem lançada em 1995, a VRML 1.0, não possibilita muita interação do usuário com o mundo virtual. Em 1996 surgiu a VRML 2.0, que acrescentava características como animação, movimento de corpos e interação com e entre usuários. Em 1997 foi iniciado um esforço para apresentar a especificação à ISO (International Standards Organization), alguns pontos foram revistos e a especificação foi reescrita e denominada VRML 97 [Vac98].

O código VRML é um subconjunto do formato de arquivo ASCII do Open Inventor, da Silicon Graphics, com características adicionais para navegação na Web equivalentes às âncoras de HTML, ou seja, pode-se criar âncoras em um mundo virtual que levem a outros mundos virtuais. Para navegar nos mundos virtuais é preciso usar browsers que suportem VRML. Assim, ao invés de visitar homepages, pode-se pensar em visitar homeworlds. Existem browsers especiais que suportam diretamente a linguagem (como o WorldView, criado especificamente para exibir objetos 
3D na plataforma Windows, e que pode ser usado como browser independente ou como uma aplicação auxiliar para um browser normal exibir documentos VRML), e browsers tradicionais, que requerem software adicional (plug-ins). Arquivos VRML podem ser criados com um editor de textos, e gravados em formato ASCII com a extensão .wrl, não precisando ser compilados nem executados [Jam97]. Na verdade, a linguagem apenas descreve como os ambientes 3D serão representados pelo browser.

\subsubsection{Características básicas}

A VRML permite a descrição de mundos 3D por meio de grafos de cena seguindo uma sintaxe e estrutura bem definidas. Um grafo de cena é um conjunto ordenado de nós que definem os elementos que compõem um mundo 3D. Os nós são organizados de maneira hierárquica, determinada pela posição que ocupam no documento VRML, ou seja, a localização de um nó no documento determina a ordem na qual o browser irá exibi-lo. Desse modo, todo objeto de um grafo de cena VRML é um nó que descreve um tipo específico de objeto, conforme ilustra a Figura 3.2.

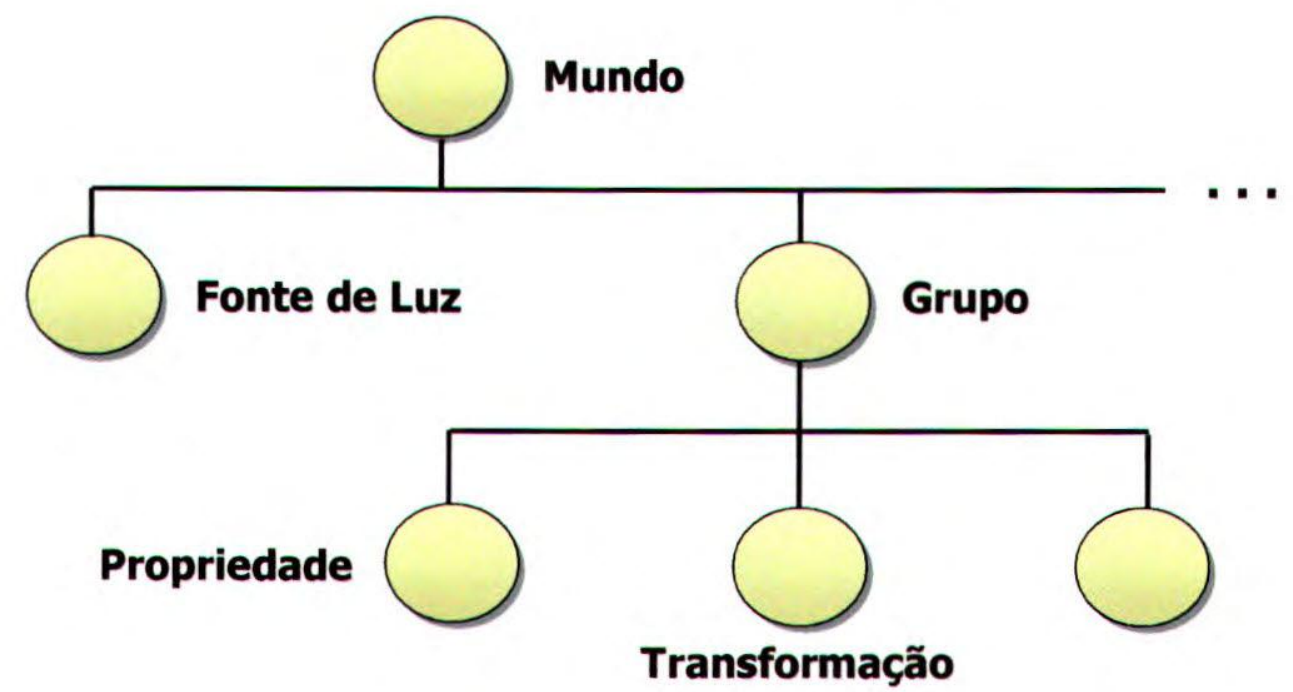

Figura 3.2 - Representação do grafo de cena em VRML

A descrição adota o sistema de coordenadas cartesiano 3D, a unidade de medida para distâncias é metros, e para ângulos é radianos. Para fins de identificação, todo arquivo VRML deve ter um cabeçalho [Jam97]. 


\subsubsection{VRML 2.0}

A versão 1.0 de VRML permite a modelagem de mundos virtuais com características e interatividade simples, nos quais os objetos são estáticos, sendo permitida ao usuário a navegação pelo mundo apenas através de alterações do ponto de observação [Nic97]. Muitos documentos VRML encontrados hoje na Web têm como base a versão 1.0. Entretanto, com os avanços oferecidos pela versão 2.0 , os projetistas e programadores estão sendo obrigados a atualizar seus documentos, uma vez que a sintaxe de definição de um objeto na versão 2.0 é totalmente diferente da versão 1.0 .

Com o uso de VRML 2.0 os objetos do mundo virtual podem mover-se e responder a eventos temporais ou do usuário, sendo essa uma das principais características associadas à nova versão. É a partir destes eventos que se obtém uma dinâmica para os objetos, sendo que cada objeto possui, além dos campos tradicionais, os campos que são o fundamento para interações [Cas97]. VRML 2.0 permite, também, a utilização de objetos multimídia, como sons e vídeos, em uma cena 3D. De forma resumida, suas características podem ser agrupadas em quatro grupos: elementos para a descrição de mundos estáticos; capacidade de interação; animação e comportamento baseado em scripts; e prototipação de novos objetos. Além disso, é possível alterar os valores e a topologia do grafo de cena durante a navegação.

A VRML inclui vários recursos para melhorar o desempenho da navegação [Cas97], como os nós de agrupamento LOD (Level of Detail); a redução do tamanho de arquivos; e a simplificação da cena. O nó de agrupamento LOD cria um grupo de representações que descreve diferentes versões de um mesmo objeto, permitindo ao browser escolher a versão apropriada do objeto de acordo com a distância entre este e o observador. Nós com menor nível de detalhe apresentam geometria simples, pouca textura e nenhum texto [Vac98]. Para reduzir o tamanho de arquivos, se um objeto é usado mais de uma vez é conveniente dar um nome ao objeto com DEF, e depois referenciá-lo com USE, ao invés de replicar a descrição. Também é conveniente eliminar os espaços em branco e usar poucas casas decimais para representar os números reais. Para simplificar a cena modelos com apelo visual podem ser criados com o uso de poucos polígonos e de texturas apropriadas, pois adicionar uma textura a um polígono é mais barato do que criar vários polígonos. Uma outra observação importante é quanto ao uso cuidadoso de recursos de iluminação, que também afetam o desempenho do mundo VRML. 
A VRML pode ser considerada uma boa altemativa para fomecer aos clientes recursos 3D na Web. Uma das suas vantagens é que a interação com os modelos 3D (mundos virtuais) ocorre no cliente, o que garante um bom desempenho para a navegação. Entretanto, esses modelos vão "prontos" para o cliente, que fica limitado apenas à interação com o modelo, não sendo possível redefinir os modelos gerados de forma integrada ao processo de navegação. Outra limitação atual é que a interação em mundos virtuais VRML nem sempre é "natural".

\subsection{Java}

Java é uma linguagem de programação desenvolvida pela Sun Microsystems em meados de 1990, quando o objetivo principal era o desenvolvimento de uma linguagem que permitisse a integração total de sistemas de computação com equipamentos eletrodomésticos [Lem96]. A linguagem permite a construção otimizada de aplicações distribuídas, ou seja, permite que múltiplos computadores sejam acessados através de uma rede e por múltiplos usuários simultaneamente. A sintaxe de Java é derivada da sintaxe da linguagem $\mathrm{C}++$, o que permite que programadores familiarizados com $\mathrm{C}++$ se adaptem facilmente à Java [Sun96].

\subsubsection{Características da linguagem}

Java é uma linguagem multiplataforma [Lem96, Lem98], o que é possível devido à estrutura interpretada que a caracteriza e o processo de compilação do código-fonte (identificado pela extensão .java), ilustrado na Figura 3.3.

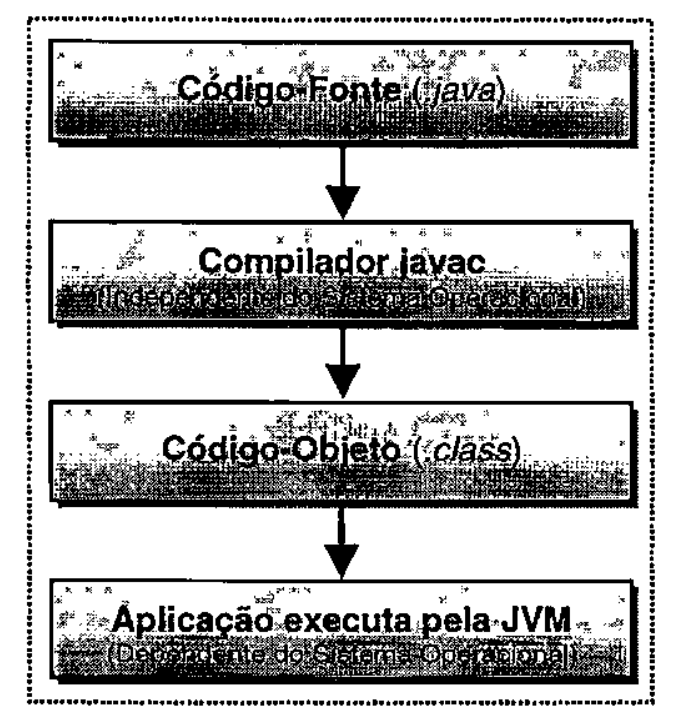

Figura 3.3 - Processo de compilação e execução em Java 
O compilador Java traduz o código-fonte em um código intermediário e independente de plataforma chamado bytecode, que é interpretado pela JVM (Java Virtual Machine), também conhecida como interpretador Java ou runtime Java. Desse modo, é possível que um programa Java seja executado em qualquer plataforma sem a necessidade de alteração no código-fonte. Outras características da linguagem são:

$>$ é dotada de recursos multithreaded, permitindo a implementação de aplicações multitarefa;

$>$ possui um vasto conjunto de componentes para a implementação de Interfaces Gráficas com o Usuário (GUI - Graphics User's Interface), por meio das classes da biblioteca AWT (Abstract Window Toolkit);

$>$ devido à sua natureza gráfica, inclui recursos de manipulação de elementos gráficos independentemente do dispositivo grafico e da plataforma operacional;

$>$ permite a manipulação de recursos de texto e características das fontes de texto;

$>$ permite o controle dos eventos de mouse e teclado sobre os objetos "encapsulados" dd interface grafica, bem como sobre eventos definidos pelo programador;

$>$ possui recursos para processamento e análise de imagens na maioria dos formatd gráficos padrões, como, por exemplo, arquivos GIF e JPEG;

$>$ permite a inclusão de bibliotecas de propósito específico pela definição de interface denominadas packages (como exemplo, pode-se citar bibliotecas para Computaçă Gráfica, Hipermídia, Programação Concorrente, Banco de Dados e outras).

Essas características fazem parte de todas as versões da linguagem Java. A partir da versão 1. também chamada de Java 2, foram inseridos recursos avançados para a construção de interfac非 com o usuário. O Java Swing, que faz parte da biblioteca JFC (Java Foundation Classes), é un extensão do AWT que foi integrada à linguagem. O Swing oferece uma funcionalidade bastant| aprimorada em relação em relação ao seu predecessor, sendo pode-se destacar [Lem98]:

$>$ a adição de novos componentes de interface (widgets);

$>$ a expansão dos recursos dos componentes existentes;

$>$ um melhor tratamento de eventos;

$>$ permite selecionar a aparência e o comportamento do ambiente (plataforma);

$>$ os componentes são implementados inteiramente em Java. 
Em uma rede heterogênea como a Internet, formada por milhões de máquinas diferentes ligadas entre si, as características de Java a colocam em posição confortável como a linguagem ideal para este ambiente. $O$ seu uso pode reduzir o custo de aplicativos que devem executar em várias plataformas, pois não é mais necessário portar e compilar o código-fonte para cada plataforma diferente, e tratar os bugs em cada uma delas individualmente, nem gerar documentação e fornecer suporte para cada plataforma. Só há uma compilação, uma documentação e um produto comercial [Tho96].

\subsubsection{Applets e aplicações stand-alone}

Um programa Java pode tomar dois rumos com relação à sua filosofia de execução: pode ser uma applet ou uma aplicação stand-alone, ou ambos, dependendo de como o programa é escrito e dos recursos que usa [Lem96]. Uma applet é definida como um "pequeno programa" Java que necessita de uma página Web e um browser (tal como Netscape Navigator, Microsoft Internet Explorer ou outros) para ser executada. Por outro lado, uma aplicação stand-alone é um programa Java que pode ser executado por um comando vindo do usuário. Como o interesse maior para esse trabalho e analisar os recursos para programação na $W e b$, a seguir trataremos especificamente de applets, pois o uso de aplicações não se encaixa nesse contexto.

Como as applets são projetadas para serem descarregadas a partir de um site remoto e depois executadas localmente, a segurança torna-se importante. Assim, as applets (ao contrário das aplicações), são restritas pelos browsers quanto ao que podem fazer [Cor97]. No momento, as applets "não assinadas" (ver Capítulo 5) não podem:

executar um programa que está na máquina local;

comunicar-se com qualquer host além do servidor a partir do qual foram transferidas;

ler ou gravar no sistema de arquivos do computador local (isso se aplica aos browsers Netscape Navigator e Internet Explorer. Outros browsers podem implementar restrições de segurança menos rígidas);

$>$ obter quaisquer informações sobre o computador local, exceto a versão de Java em uso, o nome e a versão do sistema operacional, bem como os caracteres usados para separar arquivos (por exemplo, ‘' ou ' $\gamma$ ') ou caminhos (como ':' ou ';') e linhas (como 'In' ou 'Irın'). Em particular, as applets não podem descobrir o nome do usuário, endereço do correio eletrônico etc. 
Atualmente, a versão 1.2 de Java permite que as applets façam tudo o que uma aplicação Java pode fazer, utilizando assinaturas digitais, que fomecem um mecanismo para relaxar as restrições de segurança impostas as applets. Essa questão da segurança em Java merece atenção, e será discutida no Capítulo 5, pois foi de extrema importância na implementação do VisWeb.

As applets são executadas na máquina do cliente, o que representa uma grande inovação na programação para a $W e b$, sendo que elas podem ser embutidas em documentos HTML que, assim, tornam-se interativos. Como Java é uma linguagem de programação, é muito mais fácil tornar uma applet interativa do que fazer o mesmo diretamente com uma página Web. Sem Java, criar uma página $W e b$ interativa requer o envio de dados para um script CGI no servidor. O script CGI precisa processar os dados e retomar os resultados em um formato adequado ao browser. Com as applets, o processamento é passado para o sistema do usuário que, presume-se, trabalhará mais rápido do que um servidor que esteja lidando com milhares de pedidos naquele momento. Além do mais, se muitos dados tiverem que ser calculados, não é preciso se preocupar com a velocidade de transmissão da máquina servidora, pois isso será feito localmente.

\subsubsection{Estágios do ciclo de vida de uma applet}

Toda applet Java herda um conjunto de comportamentos padrão da classe Applet. Na maioria dos casos, esses comportamentos não estão associados a qualquer ação específica visível ao usuário, a menos que se sobregrave algum dos métodos de modo a estender a funcionalidade básica da applet. Embora uma applet simples não pareça fazer muito, vários fatos estão acontecendo na retaguarda em relação à execução do ciclo de vida da mesma. Há cinco estágios neste ciclo, cada qual possuindo um método correspondente que pode ser sobregravado [Nau96]:

estágio de inicialização: o objeto applet é criado e carregado para execução, o que ocorre apenas uma vez no ciclo de vida. Nesse ponto, é apropriado criar os objetos necessários à applet, e inicializar os valores necessários a sua execução. Este estágio é executado pela sobregravação do método init 0 .

$>$ estágio de partida: ocorre quando o sistema começa a executar a applet, podendo ocorrer após o estágio de inicialização ou quando a applet é reinicializada. Este estágio é executado pela sobregravação do método start 0 .

estágio de desenho: ocorre sempre que a tela da applet precisa ser desenhada na tela do browser. Isso acontece logo após o estágio de partida e sempre que a tela da applet precise ser restaurada. Este estágio é executado pela sobregravação do método paint 0 . 
estágio de parada: o próprio browser executa o estágio de parada quando a applet não estiver visível na tela devido a um processo de navegação efetuado pelo usuário. Pode-se, ainda, atingir este estágio através da sobregravação do método stop () .

estágio de destruição: destrói a applet no final da execução. $\mathrm{O}$ browser executa este processo automaticamente. Porém, se for necessário remover recursos que a applet tenha usado durante a execução é melhor não deixar por conta do browser e sobregravar o método destroy 0 .

\subsection{Java 3D}

A API (Application Program Interface) Java 3D é uma interface de programação voltada para a criação de aplicações gráficas e applets que manipulam componentes tridimensionais [Sow97]. Ela possui mecanismos de alto nível para criar e manipular geometrias 3D, e para construir estruturas usadas no rendering dessas geometrias, permitindo a descrição de mundos virtuais complexos. Java 3D também é multiplataforma, sendo parte da suite de APIs denominada JavaMedia. É bem adaptada à Internet, justamente porque as aplicações e applets escritas com a API Java 3D têm acesso a todo o conjunto de classes de Java.

A definição da API Java 3D tomou por base as APIs gráficas existentes e, também, as novas tecnologias. Em Java 3D, as construções gráficas de nível baixo resultam de uma síntese das melhores idéias encontradas em APIs como Direct3D, OpenGL, QuickDraw3D e XGL. Da mesma forma, suas construções em alto nível sintetizam as melhores idéias encontradas em vários sistemas baseados em grafos de cena. Java 3D introduz alguns conceitos que, comumente, não são considerados como parte do ambiente gráfico, tal como o som espacial 3D. A capacidade sônica de Java $3 \mathrm{D}$ pode contribuir para oferecer ao usuário uma experiência de imersão em ambientes virtuais mais acentuada.

Um dos principais requisitos da API era o bom desempenho. Muitas decisões de projeto foram tomadas para que implementações Java 3D pudessem explorar ao máximo o hardware disponível. Outros requisitos importantes são:

fornecer um conjunto adequado de recursos para a criação de mundos 3D;

estabelecer um paradigma de programação orientada a objetos de alto nível que possibilite aos programadores o desenvolvimento rápido de aplicações e de applets sofisticadas; 
dar suporte aos carregadores em runtime. Isso faz com que Java 3D acomode uma grande variedade de formatos de arquivo, como formatos CAD específicos de fabricante, formatos de intercâmbio, VRML 1.0 e VRML 2.0.

\subsubsection{O paradigma de programação}

Os elementos gráficos em Java 3D são construídos com objetos, denominados nós, os quais podem ser tratados tanto individualmente quanto em grupo. Em função disso, objetos são interligados em uma estrutura denominada grafo de cena, que é uma estrutura simples e flexível para a representação e rendering de cenas. $O$ grafo de cena contém, ainda, uma descrição completa de toda a cena, ou universo virtual, incluindo dados geométricos, atributos e o modo de rendering a ser adotado na visualização [Nad97].

Os métodos que manipulam objetos Java 3D possibilitam acesso, alteração e interligação de nós, sendo que as ligações individuais entre nós sempre representam um relacionamento direcionado: de pai para filho. O grafo de cena é um grafo direcionado e acíclico [Sow97]. Um grafo de cena para uma aplicação simples é ilustrado na Figura 3.4. Esse grafo organiza e controla o rendering dos objetos que o compóem. O renderizador Java 3D percorre o grafo de uma maneira consistente, permitindo operações concorrentes, como o rendering simultâneo de múltiplos objetos. Isso é possível porque os grafos de cena não podem compartilhar estados entre os ramos de uma árvore.

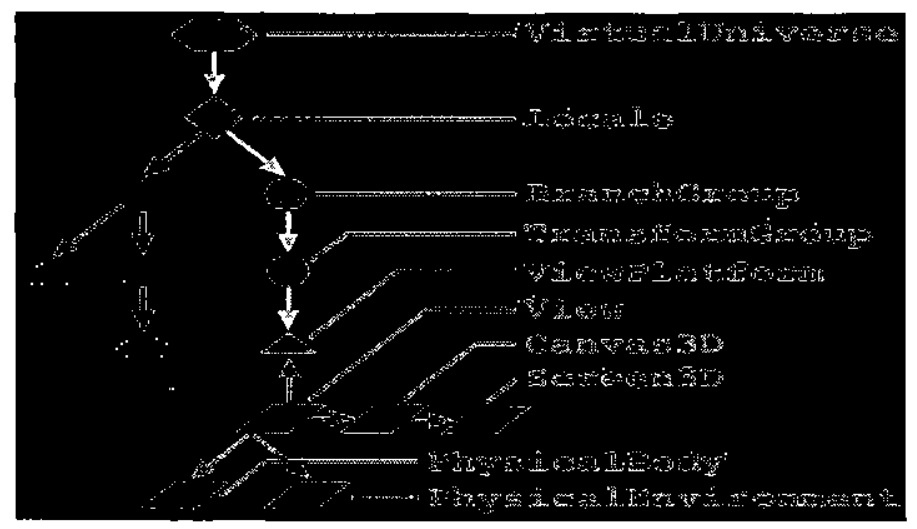

Figura 3.4 - Exemplo de um grafo de cena em Java 3D [Sow97]

O futuro de Java 3D promete ser muito promissor, pois uma de suas principais vantagens é justamente o fato de utilizar todos os recursos disponíveis em Java, adicionando recursos gráficos 3D. Uma outra vantagem é a definição de recursos de interação na própria linguagem, ao contrário de VRML. 


\subsection{Considerações finais}

As ferramentas apresentadas neste Capítulo são fundamentais para o desenvolvimento de aplicações voltadas para a WWW. Nesse contexto, foram apresentadas algumas ferramentas disponíveis, mostrando as suas características e os principais recursos de programação. No próximo Capítulo discute-se as opções para disponibilizar recursos de Visualização na WWW, mostrando os recursos existentes atualmente oferecidos pelas ferramentas apresentadas neste Capítulo, e as limitações e problemas relacionados ao uso da WWW para a visualização de dados. 


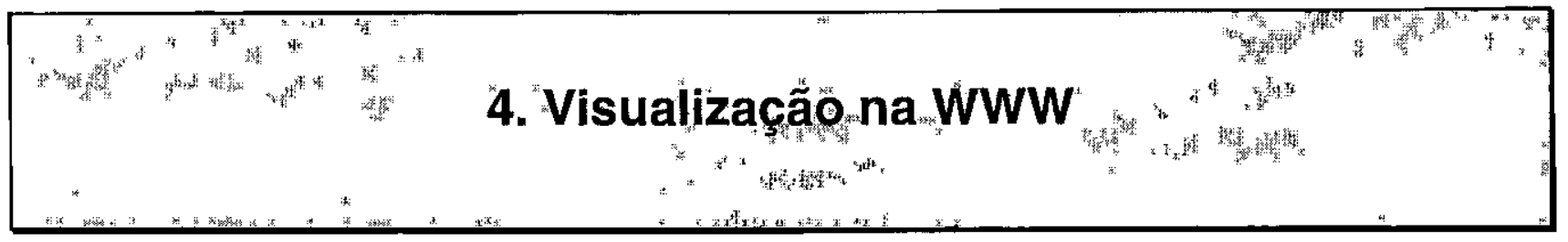

\subsection{Considerações iniciais}

A WWW tem revolucionado a maneira pela qual acessamos informação. Fontes de dados podem ser mantidas por quem os gerou, o editor; e o receptor, ou o observador dos dados, pode acessá-las convenientemente pela Internet usando um browser Web. Esse modelo de trabalho permite ao editor manter a informação continuamente atualizada, garantindo que o observador receba os dados atualizados em tempo de consulta [Woo96]. Com isso, a Web está se tornando uma nova mídia para a Visualização, mudando a maneira como as aplicações de visualização são desenvolvidas, distribuídas e usadas. Além disso, a Web oferece uma mídia rica e flexível para estabelecer a ligação entre aplicações, dados, informações e usuários [Roh97].

Este Capítulo discute como os recursos de programação para a Web podem ser utilizados para disponibilizar recursos de visualização na WWW. Na Seção 4.2 são apresentadas algumas considerações relativas à geração de visualizações estar concentrada no cliente ou no servidor Web. Na Seção 4.3 é apresentado um modelo de referência para a Visualização distribuída, mostrando alguns dos cenários existentes descritivos do processo de geração de visualizações, bem como as vantagens e desvantagens de cada um. Na Seção 4.4 são apresentadas algumas formas de se disponibilizar visualização na $W e b$, usando os recursos discutidos no Capítulo anterior, bem como as limitações associadas a essas soluções.

\subsection{Visualização no cliente versus no servidor}

Jern [Jer98] define dois tipos de clientes Web no contexto de aplicações de visualização. Um cliente "thin" exige o mínimo de software e funciona como uma interface para uma aplicação disponibilizada na $W e b$. Nesse caso, o cliente $W e b$ não é capaz de executar um programa, a menos que os executáveis sejam descarregados no próprio cliente, do mesmo modo que plug-ins ou componentes. Por outro lado, um cliente " $f a t$ " suporta interfaces gráficas com o usuário altamente interativas, cujo conforto de uso é, freqüentemente, o fator principal para considerar uma solução baseada na $W e b$. 
Entretanto, o conceito de um cliente "thin" levanta a questão do rendering da visualização no cliente versus no servidor. Os browsers Web padrões são "estáticos" e não permitem que qualquer manipulação visual seja executada no cliente. A interação do usuário com a aplicação é altamente dependente da taxa de transmissão da rede, sendo que a divisão do processo de visualização entre o cliente e o servidor seria uma maneira eficaz de distribuir os recursos computacionais.

A linguagem Java está sendo usada para superar algumas dessas limitações. Java permite a criação de applets que são automaticamente descarregadas e executadas no cliente, o que pode aumentar significativamente a interação entre a aplicação cliente e o usuário. Entretanto, as applets Java ainda são dependentes da taxa de transmissão da rede pois, dependendo do escopo e da aplicação, applets e seu conjunto de dados devem ser descarregados toda vez que estiverem sendo usados [Jer98]. Portanto, a necessidade de interação sofisticada com o usuário, manipulação de dados e alto desempenho gráfico, são as maiores razões do uso de um cliente " $f a t$ ".

\subsection{Um modelo de referência para a Visualização}

Um modelo de referência para a ViSC é proposto por Upson et al. [Ups89]. Este modelo vê o processo de visualização como um pipeline, no qual uma fonte de dados é alimentada, filtrada, mapeada e renderizada para criar uma imagem final. O processo de filtragem seleciona os dados de interesse (por exemplo, um corte); o processo de mapeamento cria uma representação geométrica abstrata dos dados (por exemplo, um mapa de contorno); e o processo de rendering, a partir da geometria 3D gerada pelo processo de mapeamento, aplica modelos de iluminação, tonalização e projeção para criar uma imagem. Esse pipeline é ilustrado na Figura 4.1.

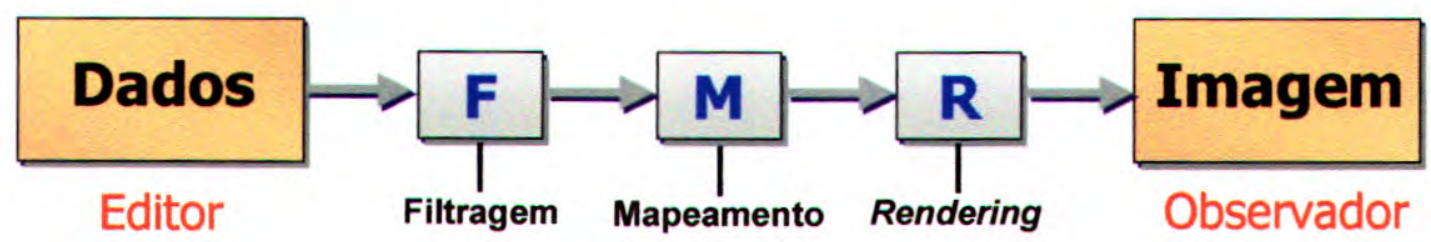

Figura 4.1 - Pipeline de Visualização

Esse modelo pode ajudar a entender a visualização na $W e b$ : os dados são gerados por alguém (o editor); a imagem é apresentada ao observador; mas cenários diferentes do processo de geração podem ser identificados quando consideramos quem tem a responsabilidade pela aplicação dos processos intermediários. Nas Subseções seguintes são discutidos alguns cenários propostos por Wood et al. [Woo96], baseados nesse modelo de referência para a visualização na Web. 


\subsubsection{Cenário 1}

Neste cenário, que é o mais usual quando se considera a Web no estágio atual, o editor cria a visualização como uma imagem. Em geral, as imagens gráficas ainda são exibidas em formatos gráficos padrão (por exemplo, GIF ou JPEG), e não necessariamente no formato originalmente usado quando de sua geração. $\mathrm{O}$ mesmo pode ser dito das animações, que são geradas anteriormente e colocadas em um formato padrão (por exemplo, MPEG) para depois serem exibidas, não permitindo nenhuma interação por parte do observador, que fica limitado a ver o resultado [Rhy95]. Esse cenário é ilustrado na Figura 4.2, interpretado em termos do modelo de referência anterior.
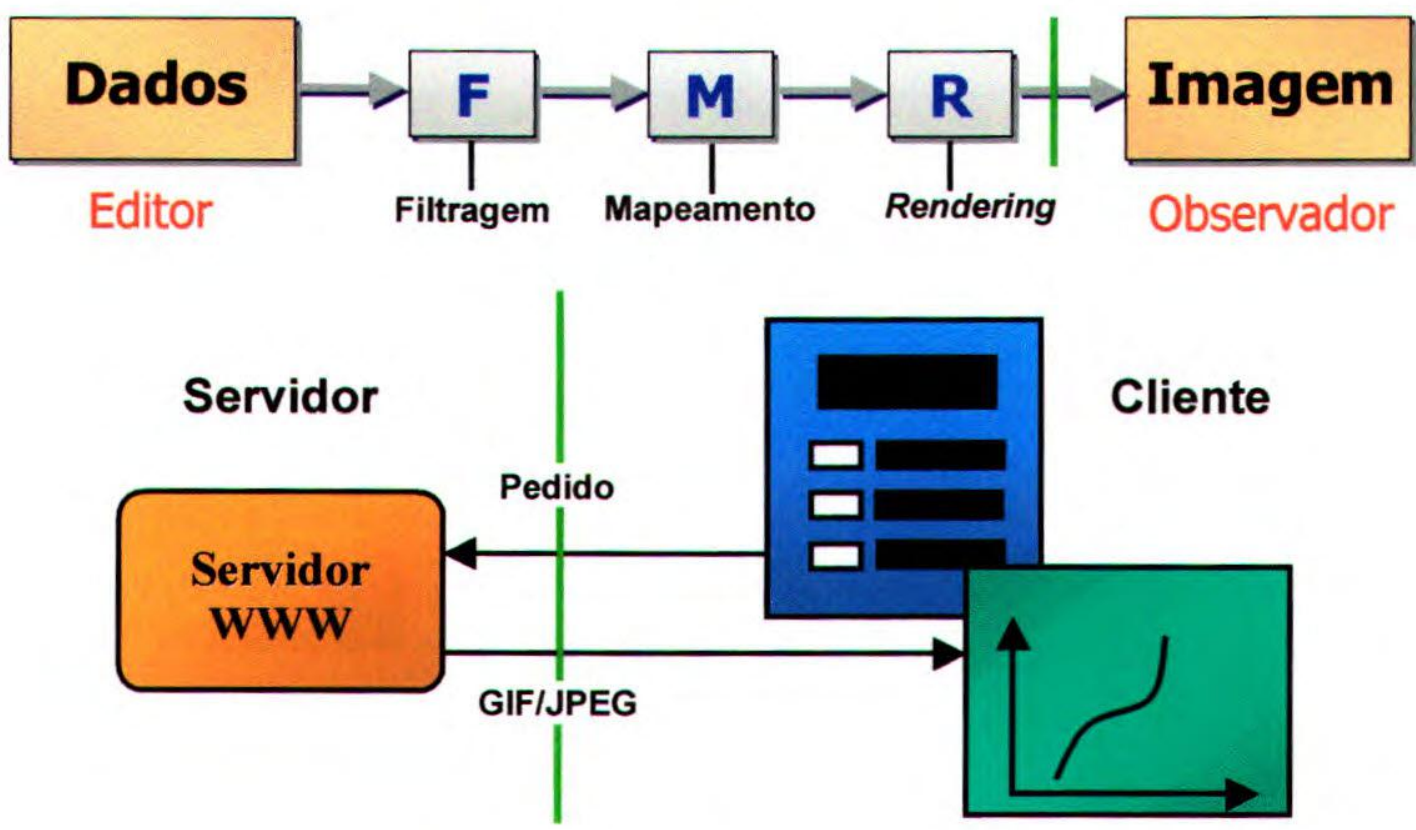

Figura 4.2 - Cenário 1: exibindo imagens na Web

As limitações dessa abordagem são: as imagens são, freqüentemente, grandes, demoram para ser transferidas e, quando chegam, estão "mortas", ou seja, o observador tem pouca oportunidade de manipulá-las.

\subsubsection{Cenário 2}

Neste cenário, o editor cria a visualização como um modelo $3 \mathrm{D}$, o que representa um avanço significativo em relação ao anterior, que usa imagens ou animações pré-gravadas. Isso é conseguido usando VRML, que permite ao observador renderizar o modelo como desejar, com a possibilidade de passear através de um espaço 3D. Esse cenário é ilustrado na Figura 4.3, sendo que o editor produz o modelo VRML e o observador interage com o mesmo usando um browser adequado. 

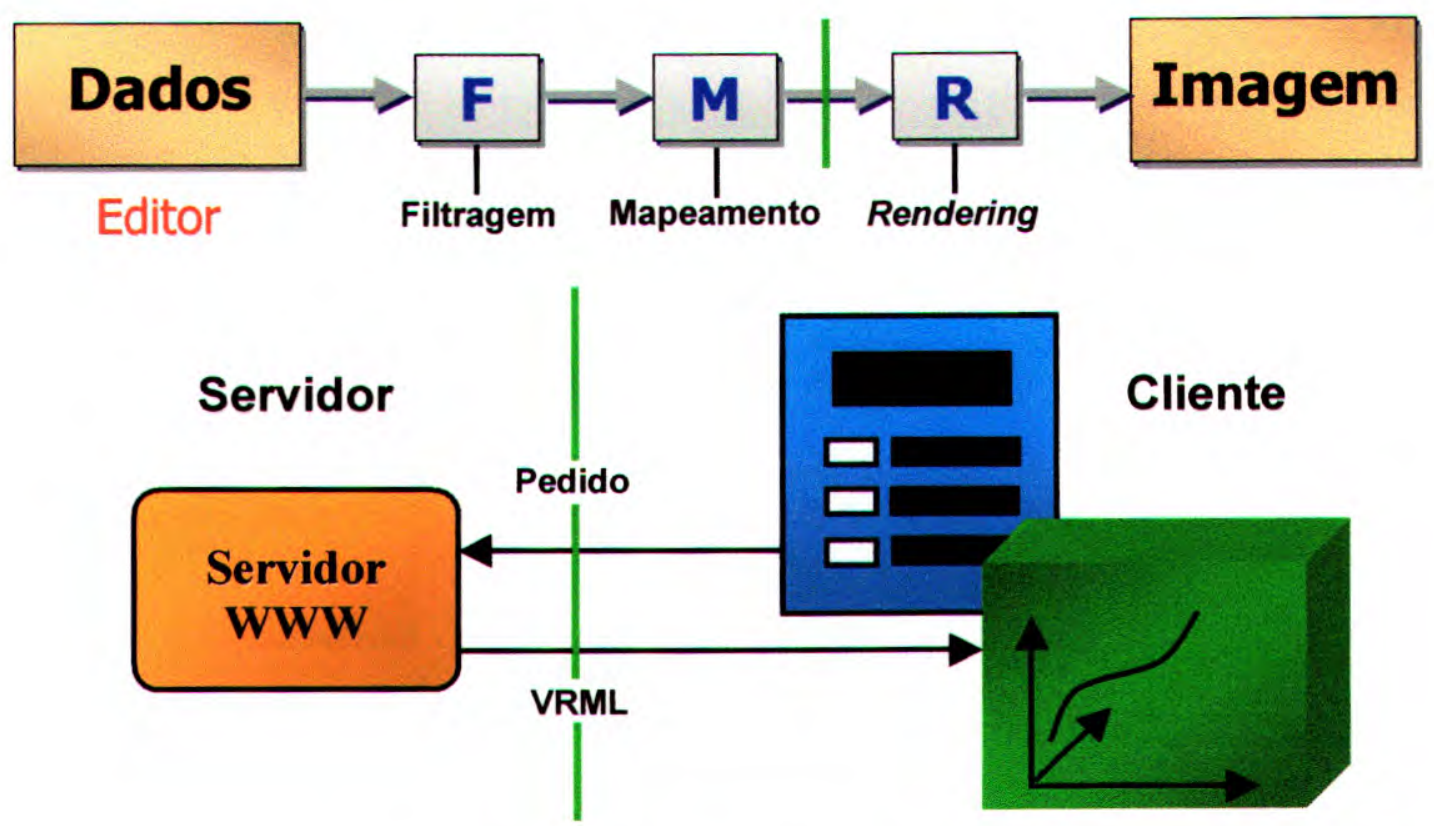

Figura 4.3 - Cenário 2: interagindo com mundos 3D na $\mathrm{Web}$

Os cenários descritos até o momento permitem ao observador ver os resultados, essencialmente, da mesma forma em que foram produzidos pelo editor, ou seja, o observador não manipula os parâmetros da visualização. Evidentemente, no caso de VRML, o observador tem muito mais liberdade para explorar o modelo, mas o modelo abstrato dos dados foi fixado, em ambos os casos, pelo gerador da informação, ou seja, pelo editor.

\subsubsection{Cenário 3}

Um cenário diferente ocorre quando o observador tem a responsabilidade pela geração da visualização, como ilustrado na Figura 4.4. Neste cenário, o editor coloca dados não tratados na $W e b$, sendo que o observador acessa esses dados e usa um sistema de visualização ou uma aplicação auxiliar para examiná-los. Em termos do modelo de referência para visualização, todo o pipeline é passado ao observador. 

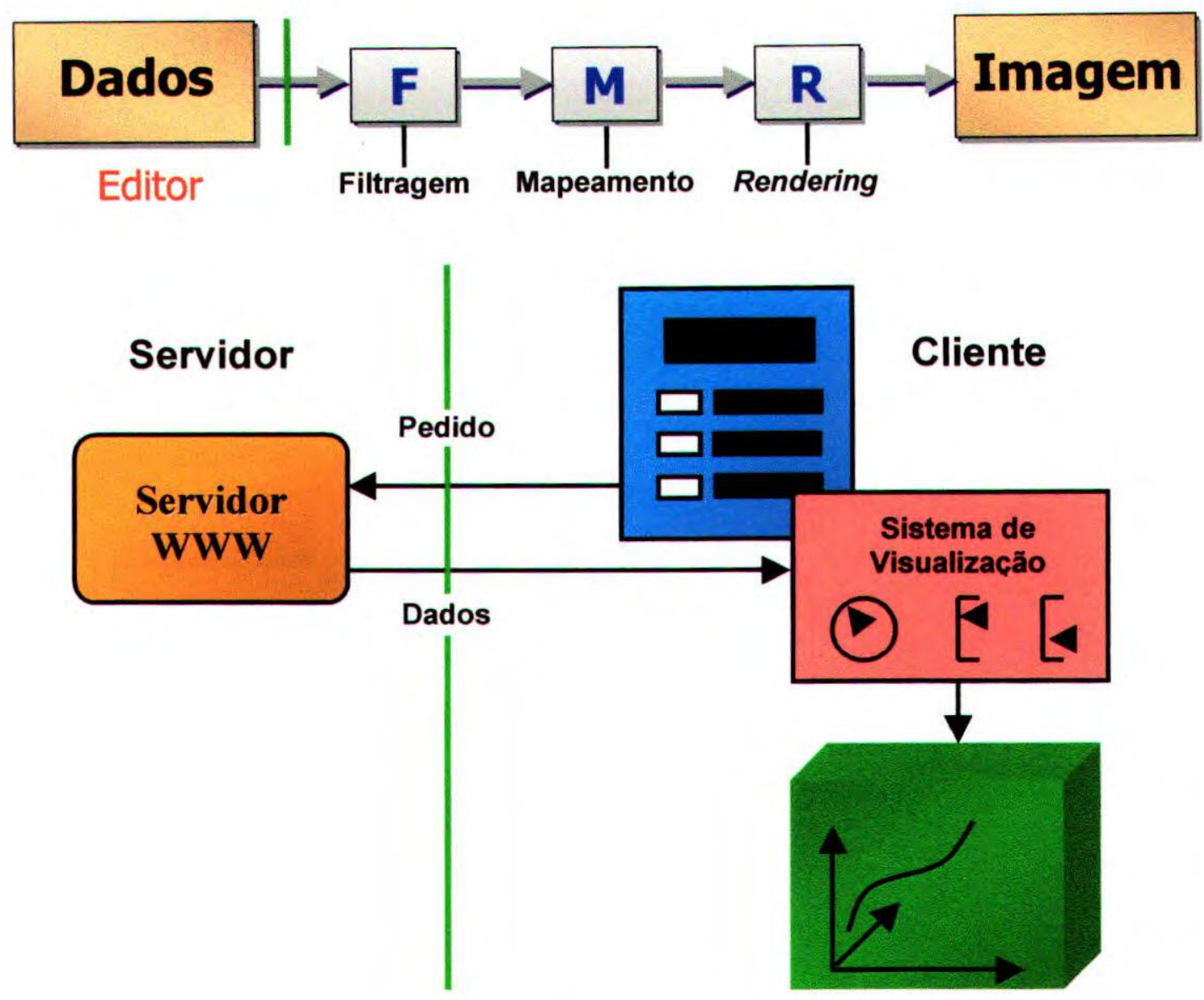

Figura 4.4 - Cenário 3: visualizando dados pela $\mathrm{Web}$

sta abordagem tem algumas vantagens: o observador tem completa liberdade para explorar os dados; estes podem não apenas ser visualizados, mas também submetidos a análises estatísticas. Por outro lado, há também algumas desvantagens: o observador deve ter um software de visualização adequado e saber usá-lo, e deve ter capacidade de processamento disponível para executar o sistema de visualização. Além disso, não existe até hoje um padrão para visualização, ou seja, sistemas diferentes usam modelos de dados diferentes, o que dificulta o processo.

\subsubsection{Cenário 4}

Os cenários anteriores atribuem toda a responsabilidade de criar as visualizações ao editor (Cenários 1 e 2) ou então ao observador (Cenário 3). Em ambos os casos, há dificuldades: deixar o processo a cargo do editor é muito inflexível, e impede que o observador interaja de forma a controlar o processo de geração das visualizações; por outro lado, deixar toda responsabilidade com o observador impõe sérios requisitos quanto à capacidade computacional. Claramente, essa é apenas uma faceta de um outro debate em andamento, que discute se o processamento computacional deve 
ser centralizado e os resultados transmitidos como um serviço de rede, ou se o poder de processamento deve ser distribuído entre os usuários finais.

Há uma solução que representa um meio termo, oferecendo em certo sentido o melhor de ambos os mundos, na qual o editor e o observador compartilham a responsabilidade. Esse cenário é ilustrado na Figura 4.5, no qual o editor oferece o poder de processamento e a estrutura de visualização básica apropriada para os dados relacionados, e o observador tem um conjunto de opções (por exemplo, um formulário HTML) para definir os parâmetros da visualização. Isso pode ser feito por uma interface com o usuário, que pode ser um formulário simples no qual opções são selecionadas e passadas ao servidor. Nesse esquema, o pipeline é executado em um servidor associado ao editor, mas o controle desse pipeline fica com o observador, que tem, assim, total responsabilidade pelo rendering (como no Cenário 2), com o modelo resultante sendo gerado e transmitido pelo editor (por exemplo, na forma de um documento VRML).
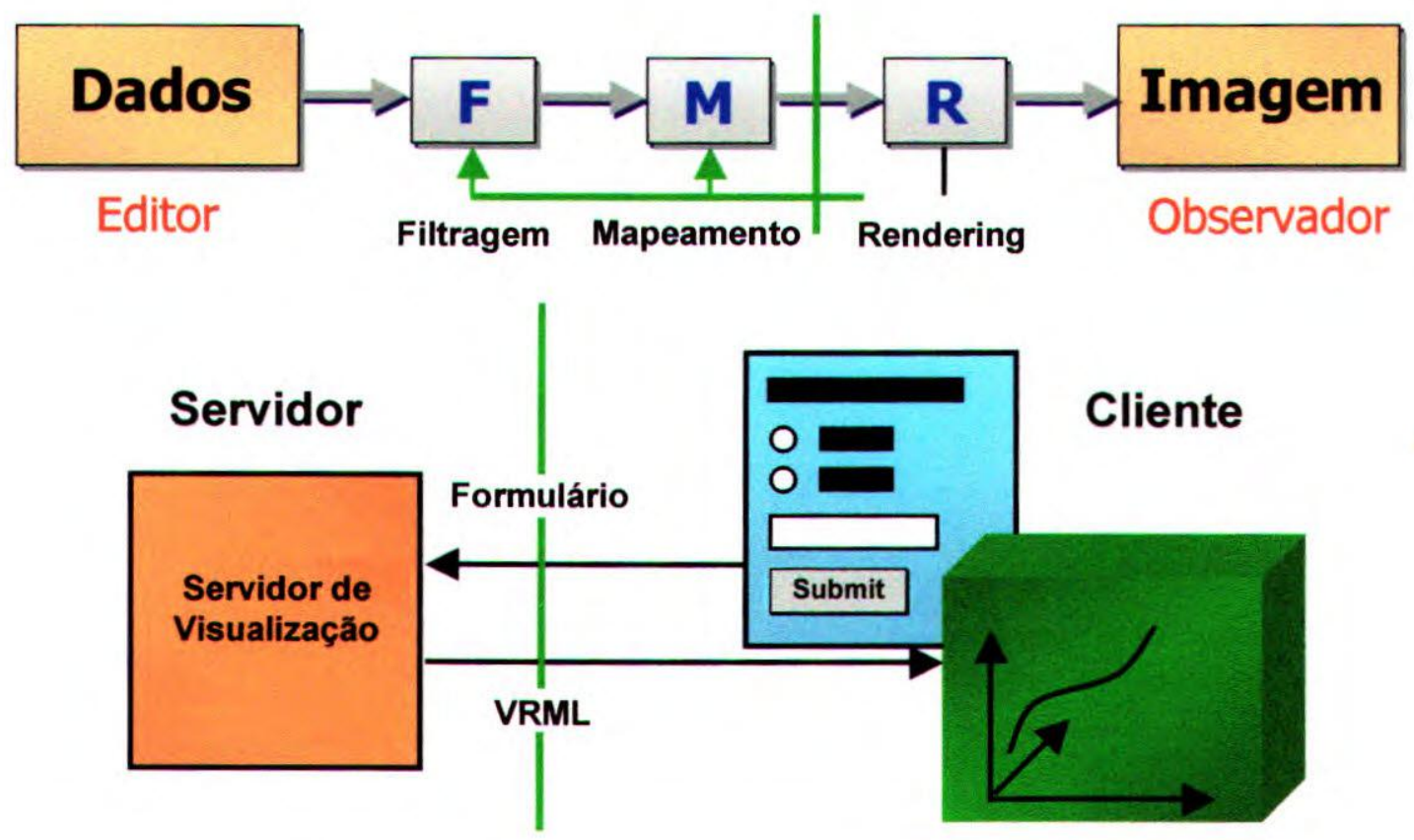

Figura 4.5 - Cenário 4: requisitando a visualização pela Web

\subsection{Recursos para visualização de dados na WWW}

Desde o surgimento da WWW houve uma evolução significativa nos recursos de visualização disponíveis para a $W e b$. Os efeitos dessas transformações têm sido significativos, permitindo a criação de páginas $W e b$ de alta qualidade que incluem animações e mundos virtuais. A melhor 
interação com o usuário é, sem dúvida, a maior motivação para essas transformações, mas no que se refere à praticidade, a interação ainda deixa muito a desejar.

Nas Subseções seguintes são discutidas algumas dessas mudanças e ilustra-se como a Web pode ser usada para tornar a visualização de dados mais acessível, interativa e poderosa. Além disso, são discutidas as vantagens e desvantagens de se criar visualizações tanto no cliente quanto no servidor, mostrando algumas alternativas possíveis utilizando as ferramentas apresentadas no Capítulo 3.

\subsubsection{Primórdios da Visualização}

Embora a WWW tenha passado a receber muita atenção a partir dos anos 90 , suas fundações remontam a décadas anteriores, quando foram criadas a Internet e a ARPanet. O que tornou os anos 90 tão significativos foi o desenvolvimento de algumas ferramentas visuais padronizadas para troca de informação, entre as quais os browsers Web como Mosaic, Netscape Navigator e Microsoft Explorer, os quais oferecem uma interface unificada que suporta muitos tipos de dados (ou conteúdos).

O primeiro tipo de conteúdo a ganhar aceitação na Web foi a linguagem HTML, que fornece uma maneira de formatar textos e imagens em um documento que pode ser compartilhado na Web, permitindo também incluir links ativos que levam o leitor (observador) a outros documentos. No caso da visualização de dados, o uso de documentos HTML com imagens ajuda a solucionar problemas de compartilhamento de resultados, mas ainda limita o usuário a observar imagens estáticas [Sch98]. Essa abordagem, segundo os cenários apresentados na Seção anterior, estaria enquadrada no Cenário 1 (ver Figura 4.2).

A limitação ao uso de imagens estáticas foi rapidamente resolvida com o advento de browsers Web capazes de suportar outros tipos de conteúdo, incluindo formatos de animação como MPEG, AVI e QuickTime. Com esses recursos, um link em um documento HTML pode carregar uma animação, que o usuário pode observar. Por exemplo, há várias maneiras de realizar a extração de isosuperfícies em um conjunto de dados volumétricos e gerar uma pequena animação. Uma delas é criar um arquivo MPEG, o qual pode ser embutido em um documento HTML. A Figura 4.6 mostra um exemplo desse tipo de visualização, gerado com o código HTML ilustrado na Listagem 4.1. Esse exemplo, assim como os demais ilustrados neste Capítulo, foi extraído de Schroeder et al. [Sch98]. 
$<$ HEAD $><$ TITLE $>$ Sample MPEG Animation Page $<$ TITLE $><$ HEAD $>$

In this page we show an MPEG animation of a visualization of the visible woman dataset. The MPEG is stored in a file tissue.mpg. We also have taken one frame from the animation and stored it as a static JPEG image tissue.jpg. We display the JPEG image so that someone visiting the site will have an idea of what the mpeg animation will contain.

$<$ BR $><$ A HREF="tissue.mpg" $><$ IMG SCR="tissue.jpg" $>$

$<\mathbf{B R}>$ Click here for an MPEG Animation $</ \mathrm{A}>$

Listagem 4.1 - Exemplo de um documento HTML referenciando uma animação MPEG

O exemplo mostra uma animação MPEG criada para exibir informações extraídas do conjunto de dados da "mulher visível". Ainda assim, a animação é pré-gravada, e o usuário não interage com ela, de forma que continuamos no Cenário 1.

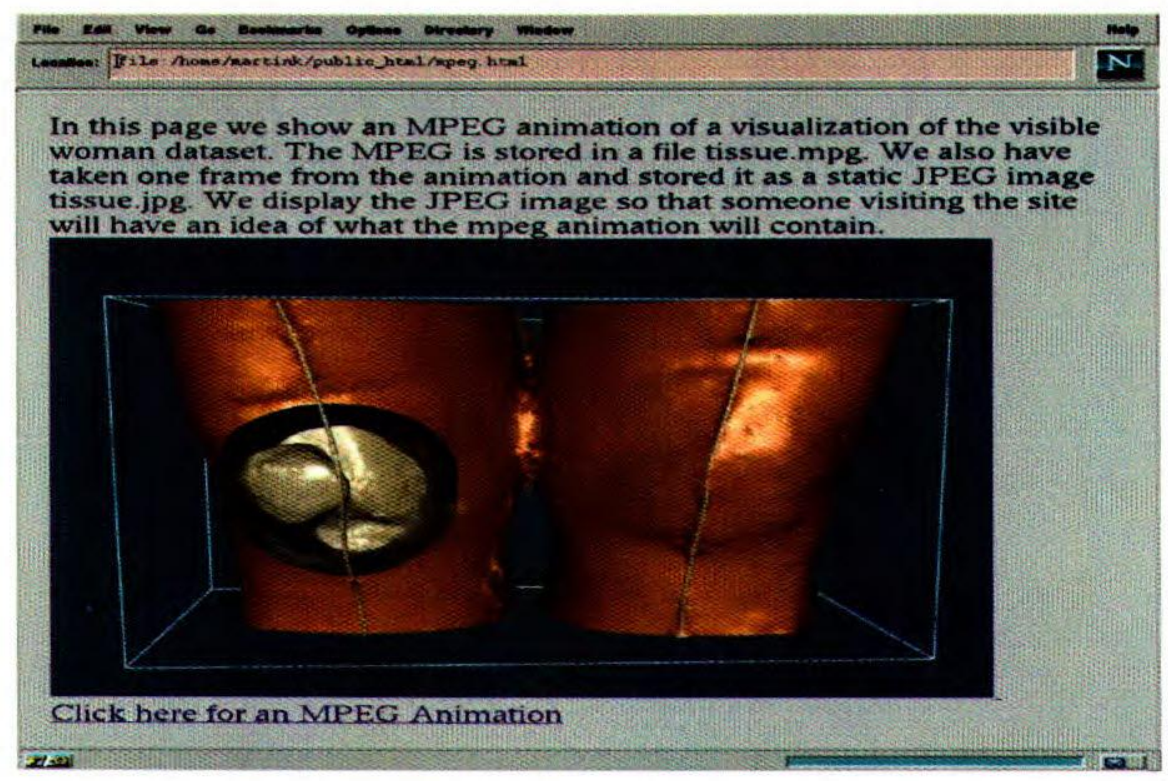

Figura 4.6 - Exemplo de visualização usando MPEG [Sch98]

O próximo passo na evolução dos recursos foi dar ao cliente o controle sobre a seqüência de geração da animação no servidor. Para facilitar esse processo, foi introduzido um mecanismo para permitir ao cliente o envio de informações genéricas para o servidor. O CGI, juntamente com formulários HTML, atendem esta proposta. Nesta abordagem, um formulário HTML coleta informações do cliente, transmite-as ao servidor que executa um script CGI e, finalmente, produz um resultado para o cliente observar.

A Figura 4.7 ilustra o uso de CGI com um formulário HTML, permitindo que o cliente mude o valor da isosuperfície. O formulário foi gerado com o código HTML ilustrado na Listagem 4.2. 


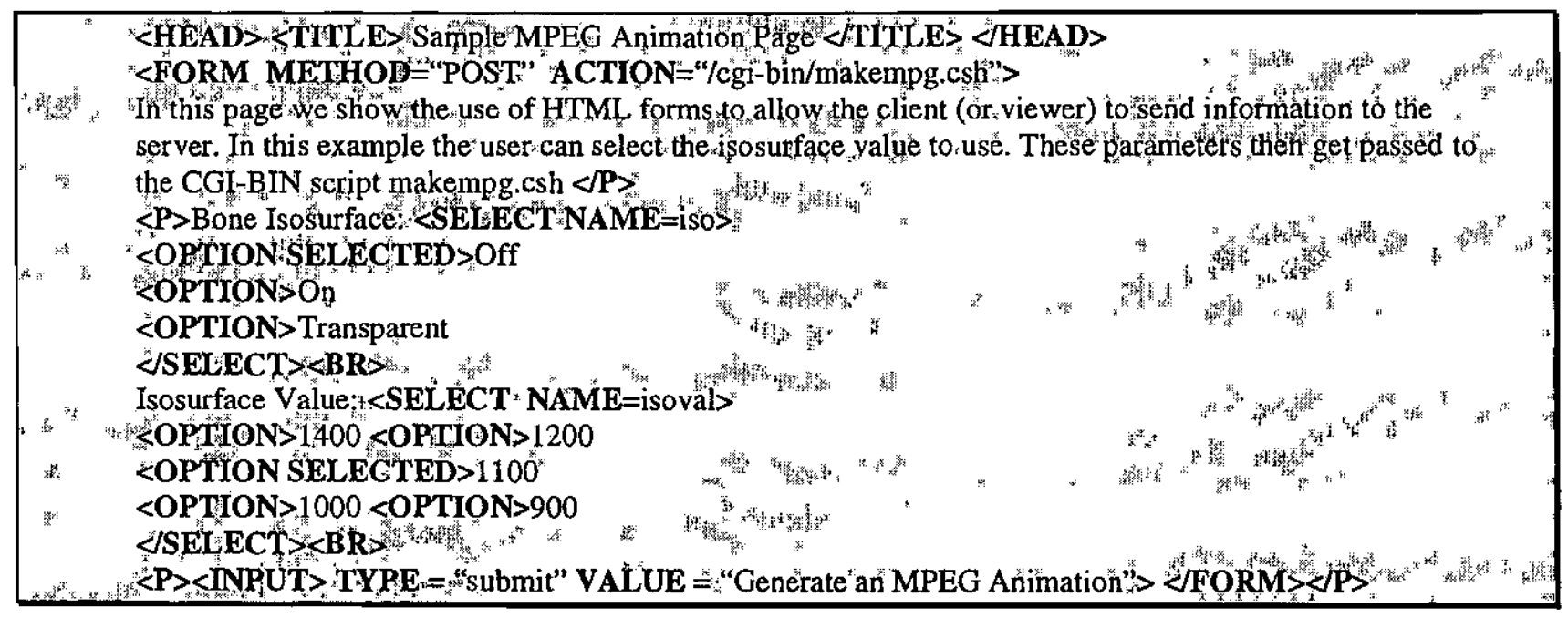

Listagem 4.2 - Exemplo de um documento HTML contendo um formulário

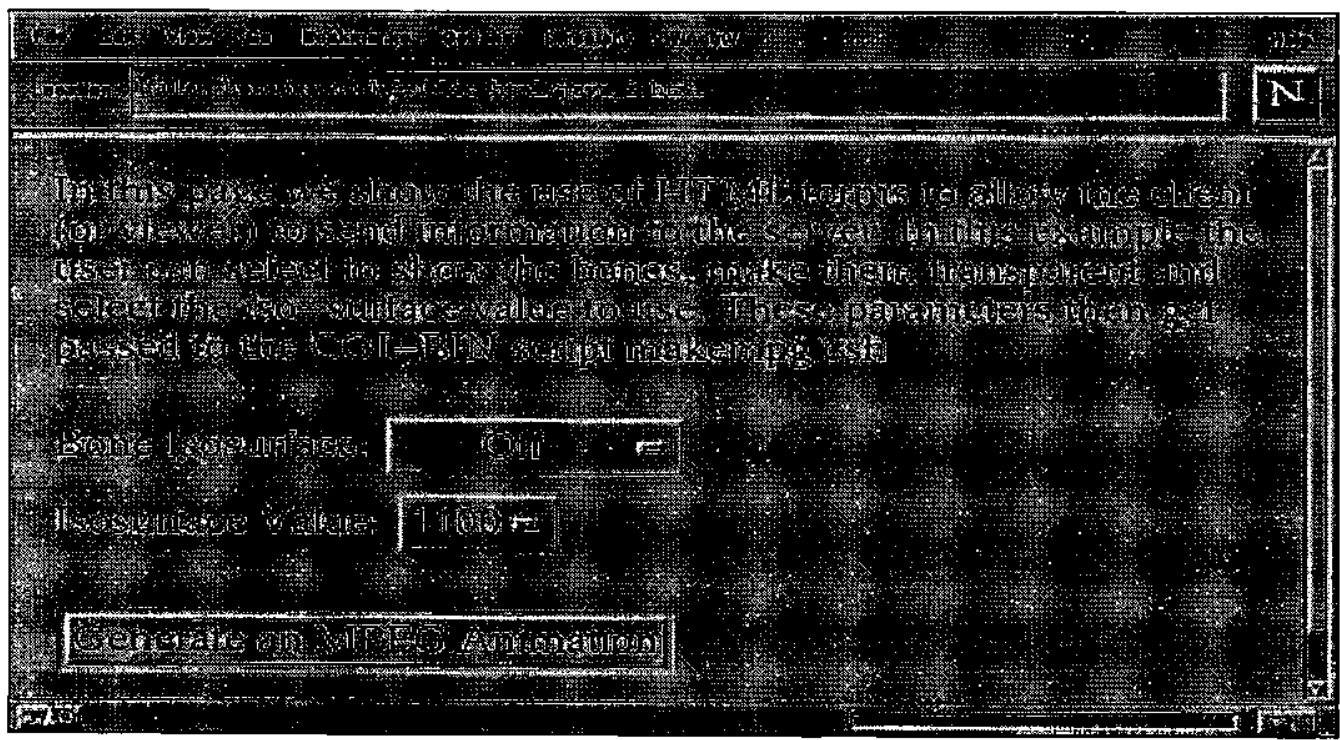

Figura 4.7 - Exemplo de um formulário HTML [Sch98]

Assim que o cliente submete o formulário, o servidor chama o script CGI e passa as informações fornecidas. O script gera uma nova animação MPEG baseada nessas informações, retornando-a ao cliente. Esse exemplo caracteriza um cenário no qual o usuário pode definir parâmetros para a geração da visualização, mas não interage diretamente com os modelos gerados na mesma.

Nesses exemplos, existe um laço fechado de interação entre cliente e servidor, mas dois problemas permanecem. Primeiro, essas abordagens colocam toda a carga computacional no servidor. Ainda que isso possa ser viável para algumas aplicações, alguns servidores podem literalmente receber milhões de pedidos por dia, sobrecarregando seriamente os seus recursos. Segundo, embora o 
processo seja interativo, o tempo de espera entre fazer uma mudança e ver os resultados pode ser considerável, dependendo do tamanho da animação e da largura de banda da comunicação.

\subsubsection{Visualização usando VRML}

Apesar de ser uma ferramenta poderosa para a criação de documentos hipertexto, a HTML não suporta conteúdo tridimensional. Essa limitação pode ser grave se estivermos interessados em explorar dados 3D e não sabemos exatamente o que desejamos ver ou apresentar para um usuário. Como consequiência, um desenvolvimento importante foi a possibilidade de criar modelos de mundos 3D nos quais o usuário pudesse navegar livremente. Como resultado dessa necessidade de maior interatividade, surgiu a VRML, já apresentada no Capítulo anterior.

A idéia básica por trás de VRML foi criar um padrão de definição para a transmissão de conteúdo 3D na Web. Esse conteúdo é descarregado do servidor, e a interação ocorre no cliente. Isso ajuda a solucionar tanto o problema de carga excessiva no servidor, quanto o alto tempo de interação associado à abordagem anterior de gerar animações MPEG no servidor. Muitos sistemas de visualização, incluindo o VTK, permitem a exportação de cenas para arquivos VRML. Na próxima Subseção, é exemplificado um servidor de visualização que faz uso de VRML e do VTK.

\subsubsection{Um servidor de visualização VRML}

O exemplo anterior, do servidor de visualização MPEG, pode ser melhorado criando um servidor de visualização VRML. No exemplo melhorado, a idéia básica é a mesma de antes, ou seja, é usado um formulário HTML para definir os parâmetros para a visualização, que então dispara um script CGI. A diferença é que, neste exemplo, o servidor vai gerar um documento VRML, que será retornado ao cliente. O cliente poderá, então, controlar o ponto de observação e o rendering do modelo VRML. Os dados e o sistema de visualização ainda residem no servidor, sendo que o cliente precisa apenas ter um browser Web compatível com VRML. Essa abordagem se enquadra no Cenário 4 da Seção anterior (ver Figura 4.5).

Neste exemplo, o formulário HTML é, essencialmente, o mesmo usado no exemplo anterior, ilustrado na Figura 4.7. O que muda é que o script CGI produz um documento VRML, ao invés de um MPEG. Para isso, o script precisa extrair os valores informados no formulário, que são passados pelo browser ao servidor de forma codificada. A Listagem 4.3 mostra como extrair esses valores em $\mathrm{C}++$. 


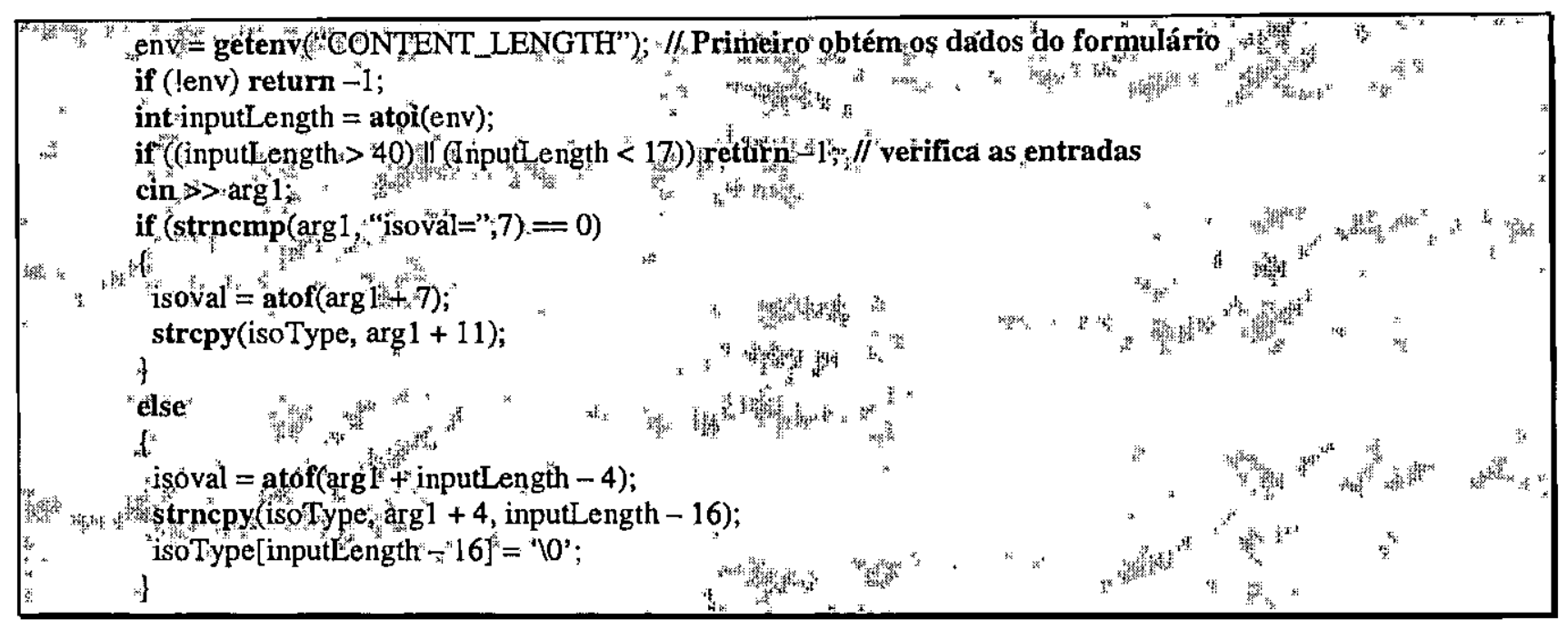

\section{Listagem 4.3 - Exemplo de um script CGI usando C++ e VTK}

Uma vez obtidos os dados do formulário, eles podem ser usados para definir o pipeline de visualização, como usual. Na Listagem 4.4, uma isosuperfície é adicionada ao renderer baseado na entrada de "isoType" do formulário.

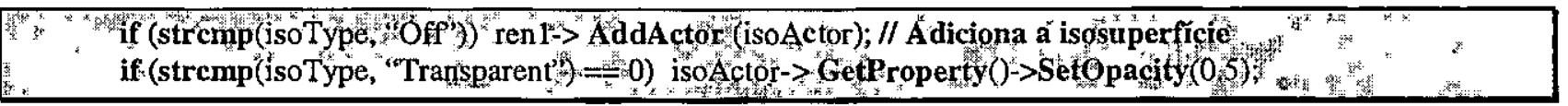

Listagem 4.4 - Exemplo de um script CGI usando C++ e VTK (Continuação)

Uma vez que o pipeline foi definido, o último passo é gerar um cabeçalho próprio e uma saída VRML. A Listagem 4.5 mostra como fazer isso, usando a classe do VTK que exporta VRML.

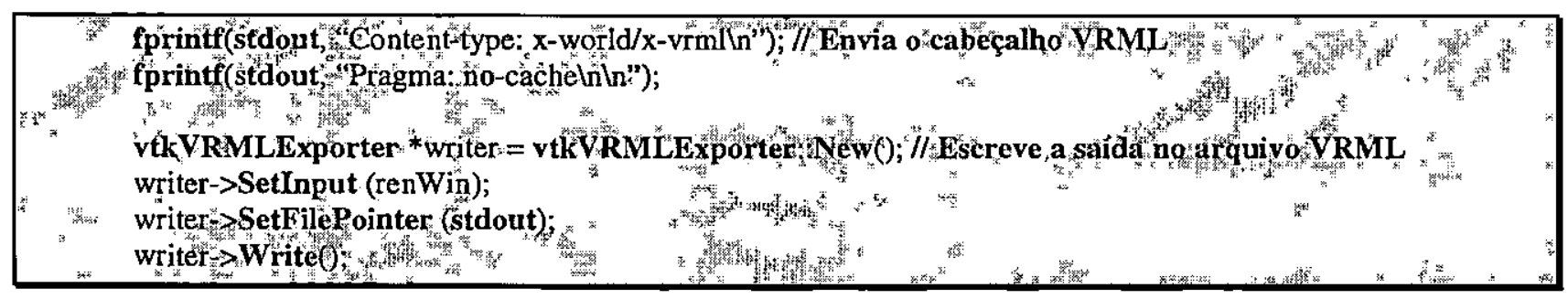

Listagem 4.5 - Exemplo de um script CGI usando C++ e VTK (Continuação)

Uma instância de vtkVRMLExporter é criada, associada a uma instância de vtkRenderWindow como entrada, e sua saída é redirecionada para a saída padrão. Quando o método Write é aplicado, - "exportador" atualiza o pipeline de visualização e produz uma saída VRML. O objeto vtkRenderWindow nunca será renderizado e a janela associada não aparecerá no servidor. A interação fica por conta do browser VRML do cliente, não havendo necessidade de um objeto interactor do VTK. 


\subsubsection{Visualização usando Java}

Os exemplos discutidos até agora ilustram várias maneiras de gerar visualizaçōes baseadas na Web. Cada estratégia tem seus benefícios, mas falta a flexibilidade encontrada em programas desenvolvidos para esse fim, e é nisso que Java se destaca. A linguagem foi projetada para trabalhar em uma ampla variedade de hardware sem a necessidade de recompilação e com alta confiabilidade. Essas mesmas qualidades são valiosas para programação na $W e b$, onde programas simples devem executar em diferentes tipos de máquina sem falhas [Sch98].

Como Java é uma linguagem de programação completa, qualquer aplicação de visualização escrita nessa linguagem executará em qualquer sistema compatível. Além disso, Java permite gerar a visualização no servidor, no cliente ou em ambos. Vários programas Java têm sưrgido que são capazes de renderizar geometrias simples ou exibir seqüências de imagens, mas o desafio atual é executar visualizações "reais". Até pouco tempo atrás, Java tinha desempenho ruim em relação a $\mathrm{C}++$ e não dispunha de uma conexão direta para explorar hardware gráfico 3D (se disponível). Com a introdução de Java 3D, esses problemas podem desaparecer, restando apenas um problema: a falta de uma API de visualização para a linguagem.

Embora Java seja uma linguagem interpretada e portátil, seus projetistas perceberam a importância de ter um mecanismo para que desenvolvedores fizessem chamadas a rotinas escritas em $\mathrm{C}$ ou $\mathrm{C}++$. Esse mecanismo é chamado de JNI (Java Native Interface), e oferece uma maneira clara e bem definida para que o código nativo em $\mathrm{C} \mathrm{e} \mathrm{C}++$ opere dentro do ambiente Java. Isso permite o uso de um sistema de visualização como o VTK, o que por sua vez garante um mecanismo para acessar hardware gráfico 3D. O código nativo também permite que funçōes cujo desempenho é crítico sejam implementadas em código $\mathrm{C}$ ou $\mathrm{C}++$ otimizado, ao invés de em Java, com suas atuais limitações de desempenho.

A desvantagem de usar JNI e código nativo é que isso sacrifica um pouco a portabilidade. Enquanto que um programa Java puro pode ser interpretado e executado em qualquer máquina que suporte a linguagem, um programa que usa código nativo de outra linguagem requer que o compilador dessa linguagem esteja instalado no cliente, sendo que para cada tipo de máquina que se deseja suportar é necessário ter uma versão compilada do código nativo. Para um toolkit como o VTK, é preciso que o cliente descarregue o suporte nativo antes de começar a executar aplicações que usam Java com VTK. Dependendo das necessidades da aplicação, os dados ficam no servidor e apenas os 
resultados são enviados para o cliente, ou os dados podem ser enviados para o cliente tanto para o processamento quanto para a observação.

O próximo exemplo mostra como usar Java e VTK para exibir alguns modos de vibração de uma placa retangular. Esses modos de vibração são mapas de deslocamento que ilustram o movimento de um objeto, no caso a placa. Nesse exemplo não é necessário usar um formulário HTML como nos anteriores, pois Java permite construir uma interface com o usuário para obter as informações requeridas. A Listagem 4.6 mostra o primeiro passo, que é criar um documento HTML que irá disparar a applet Java.

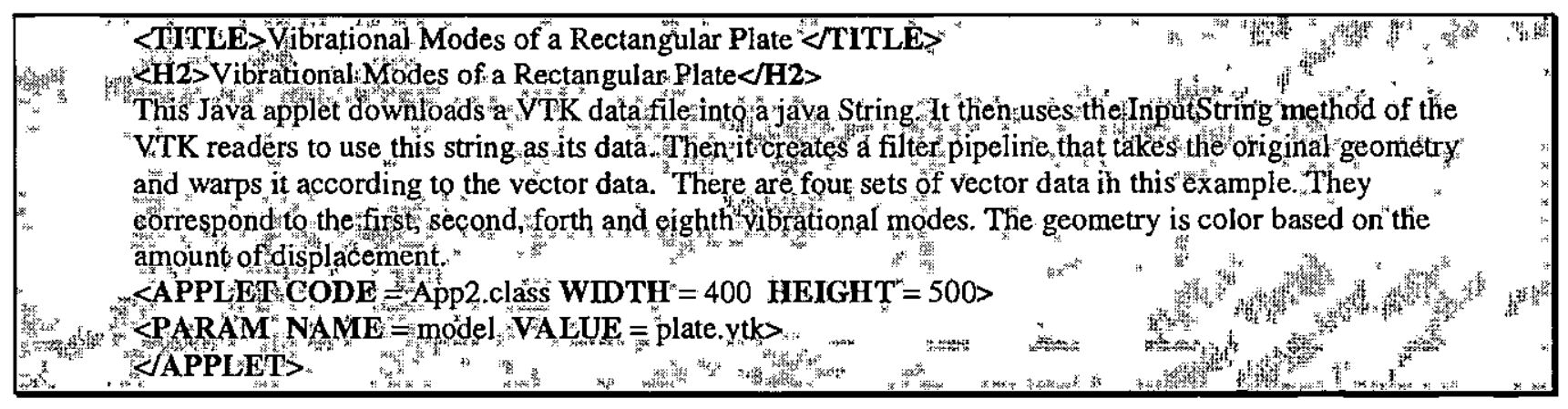

Listagem 4.6 - Exemplo de um documento HTML referenciando uma applet que faz uso do VTK

Quando o cliente encontra a palavra-chave APPLET, ele pede a applet Java especificada ao servidor e inicia sua execução. As primeiras linhas da applet, ilustradas na Listagem 4.7, importam outras classes que serão usadas. Java usa a classe VTKModel para ler arquivos de dados do VTK através da Web. A linha import vtk.* fornece acesso a todos os objetos nativos do VTK.

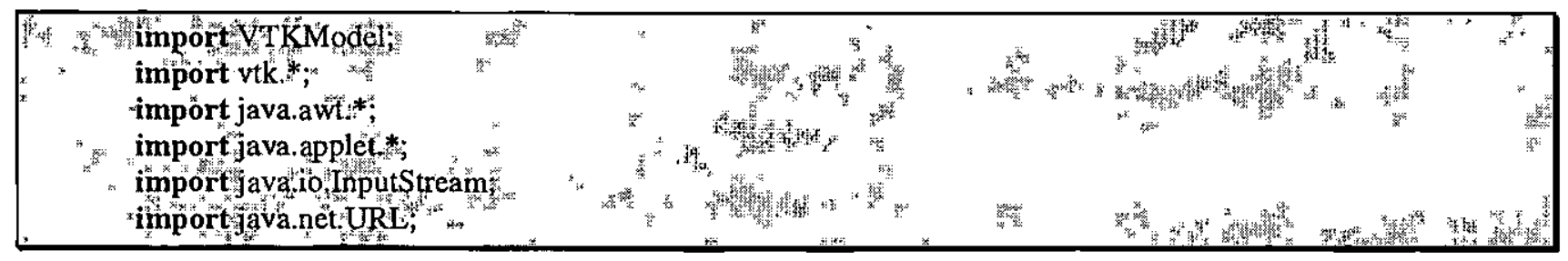

Listagem 4.7 - Exemplo de uma applet Java com VTK

Em seguida aparece a definição de uma classe App2, como ilustrado na Listagem 4.8. Como na maioria das applets Java, esta classe estende a classe Applet. Ela tem algumas variáveis de instância, incluindo alguns objetos VTK que serão usados para montar o pipeline de visualização. 


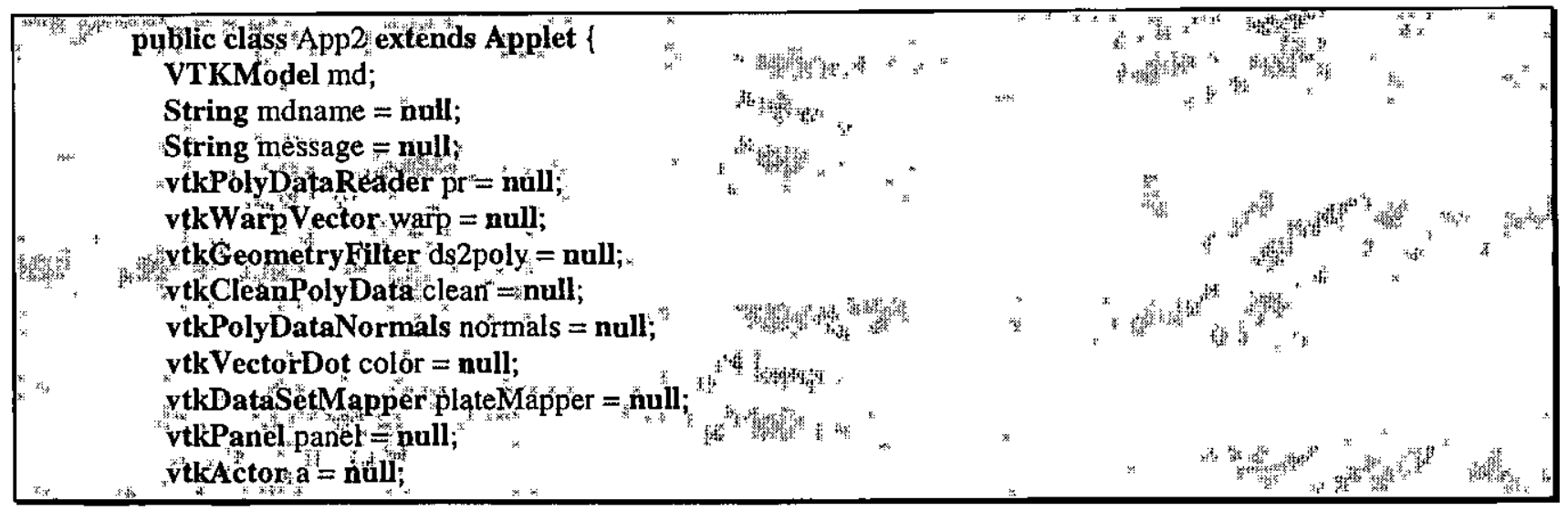

Listagem 4.8 - Exemplo de uma applet Java com VTK (Continuação)

O método init(), ilustrado na Listagem 4.9, lida com a inicialização da applet. É nele que os parâmetros do documento HTML serão processados, e o pipeline de visualização e a interface com o usuário serão montados. Para colocar a janela de rendering dentro da interface do usuário foi utilizada a classe vtkPanel, que é uma subclasse da classe Canvas de Java. Desse modo, a janela de rendering pode ser tratada como se fosse exatamente uma outra componente da interface com o usuário.

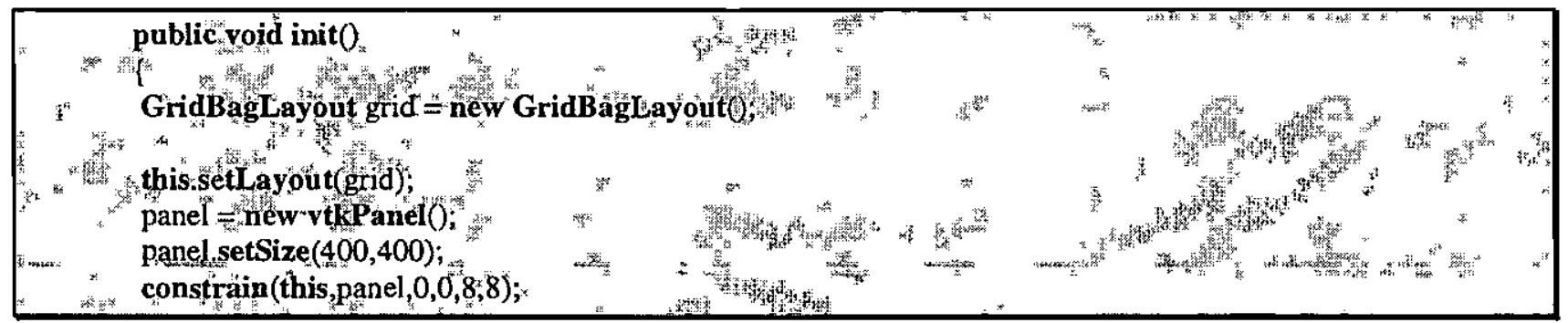

\section{Listagem 4.9 - Exemplo de uma applet Java com VTK (Continuação)}

No trecho de código exibido na Listagem 4.10 é verificado se o parâmetro "model" foi fixado, e é aberta uma conexão stream com o servidor para que a classe VTKModel a use para descarregar o arquivo de dados em uma string Java. Esta é, então, passada para o vtkPolyDataReader, para disponibilizar os dados para o código nativo no cliente.

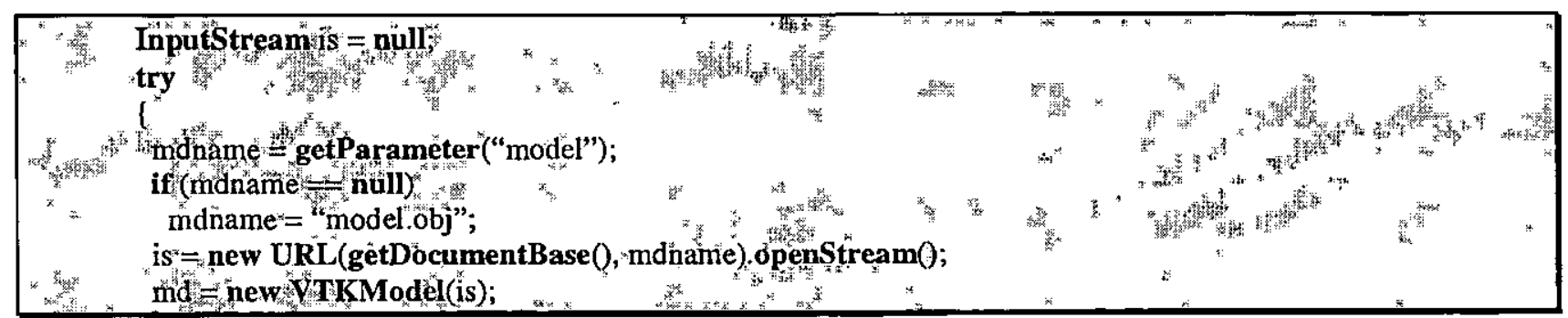




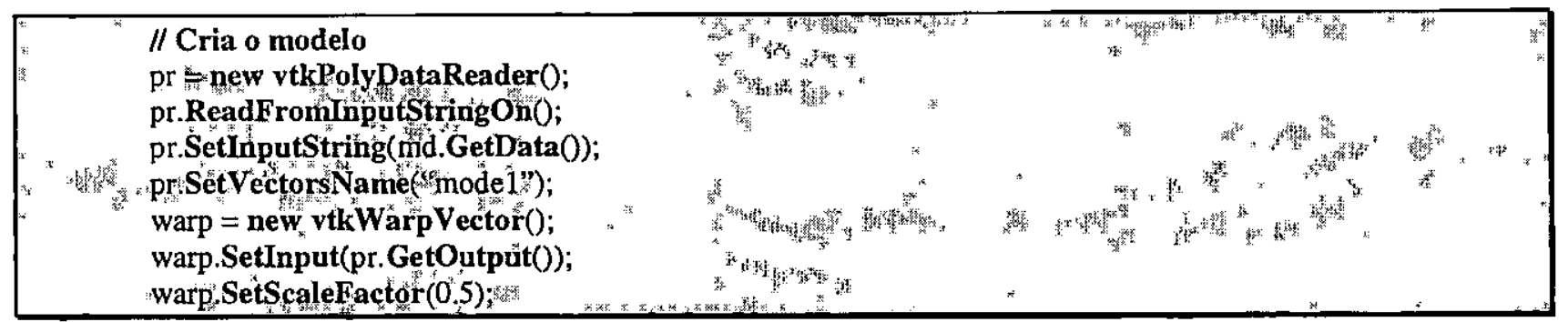

Listagem 4.10 - Exemplo de uma applet Java com VTK (Continuação)

O restante do pipeline é montado da mesma maneira que em $\mathrm{C}++$ ou $\mathrm{Tcl}$, com a exceção de que a sintaxe de Java está sendo usada. O resultado da execução dessa applet é ilustrado na Figura 4.8.

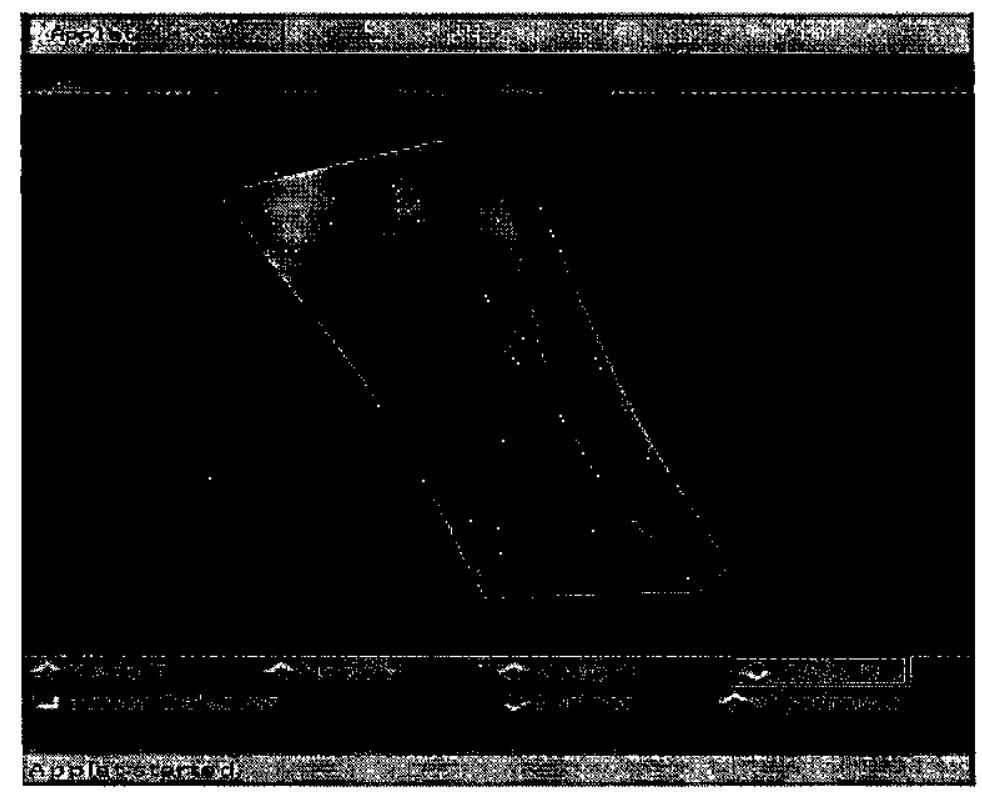

Figura 4.8 - Exemplo de uma visualização usando Java e VTK [Sch98]

Esse exemplo demonstra uma das vantagens de usar Java para visualização na Web, numa abordagem que pode ser enquadrada como um meio termo entre os Cenários 3 e 4 (ver Figuras 4.4 e 4.5). O pipeline é executado no cliente, mas é disponibilizado no servidor. Uma solução usando VRML exigiria que a geometria de cada modo de vibração da placa fosse enviada ao cliente para observação. Com Java e VTK a geometria pode ser enviada uma única vez junto com um conjunto de deslocamentos escalares para cada modo de vibração. Então, o cliente pode "alternar" entre os modos vibracionais oferecidos (ver Figura 4.8), sendo que a geometria pode ser modificada rapidamente pelo cliente sem qualquer tráfego adicional na rede. Além disso, o cliente poderia combinar os modos vibracionais ou realizar uma animação mostrando a vibração da placa sem precisar voltar ao servidor, e sem requerer muito mais dados do que um único modelo VRML da placa. Entretanto, se o cliente decidir examinar uma outra geometria, é possível retornar ao servidor 
para acessar novos dados. É pela flexibilidade oferecida que Java tem se tornado um mecanismo popular para implementar interação no cliente em aplicações Web [Roh97].

\subsubsection{Visualização usando Java 3D}

Embora o uso de código nativo (por exemplo, uma implementação do VTK) em um ambiente Java forneça um mecanismo para explorar a aceleração oferecida por hardware gráfico, o Java 3D é uma tentativa de produzir tal suporte como parte da API padrão de Java. A API Java 3D ainda não está consolidada, mas grande parte de sua estrutura básica já foi finalizada [Sow97, Sch98]. Java 3D oferece tanto rendering baseado no grafo de cena, de forma similar à VRML, quanto um modo de rendering imediato de alto nível. $\mathrm{O}$ suporte ao modo de rendering imediato não é tão completo quanto em bibliotecas como a OpenGL, mas oferece um bom subconjunto dessa funcionalidade. A Listagem 4.11 mostra o código de uma applet em Java 3D, ilustrando a sintaxe de um programa para construir um cubo simples e estático. O resultado desse exemplo é ilustrado na Figura 4.9.

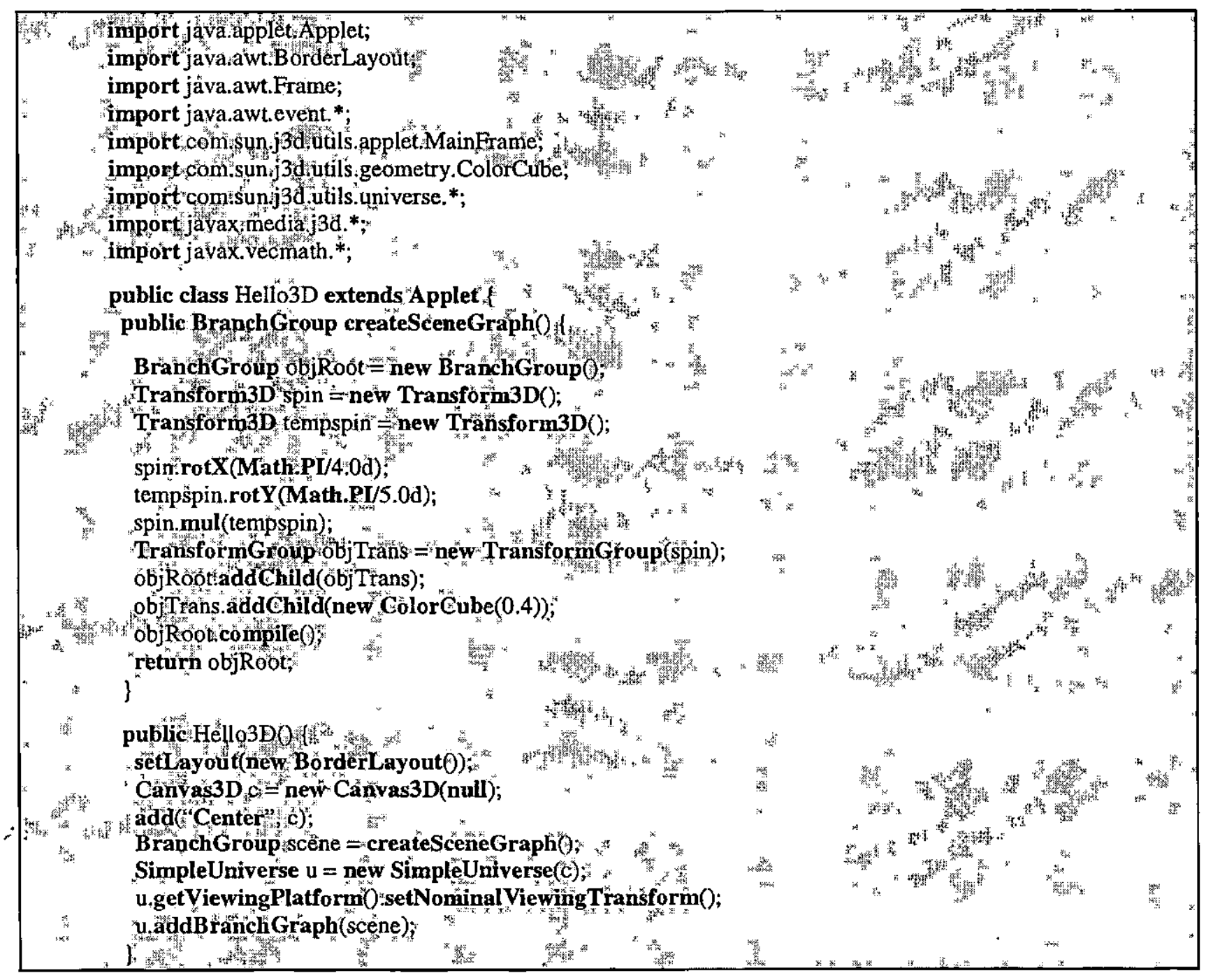




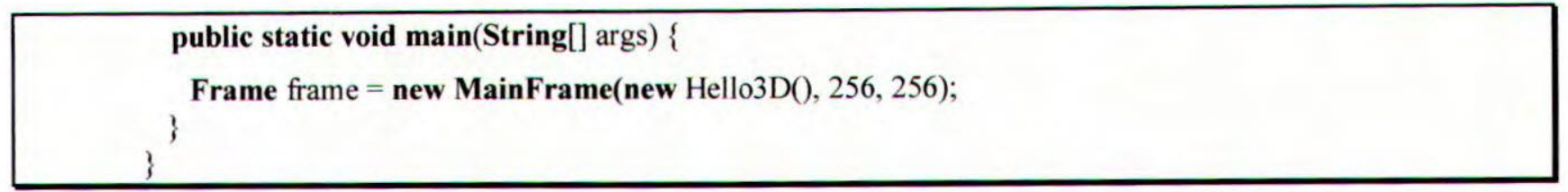

Listagem 4.11 - Exemplo de uma applet que utiliza Java 3D

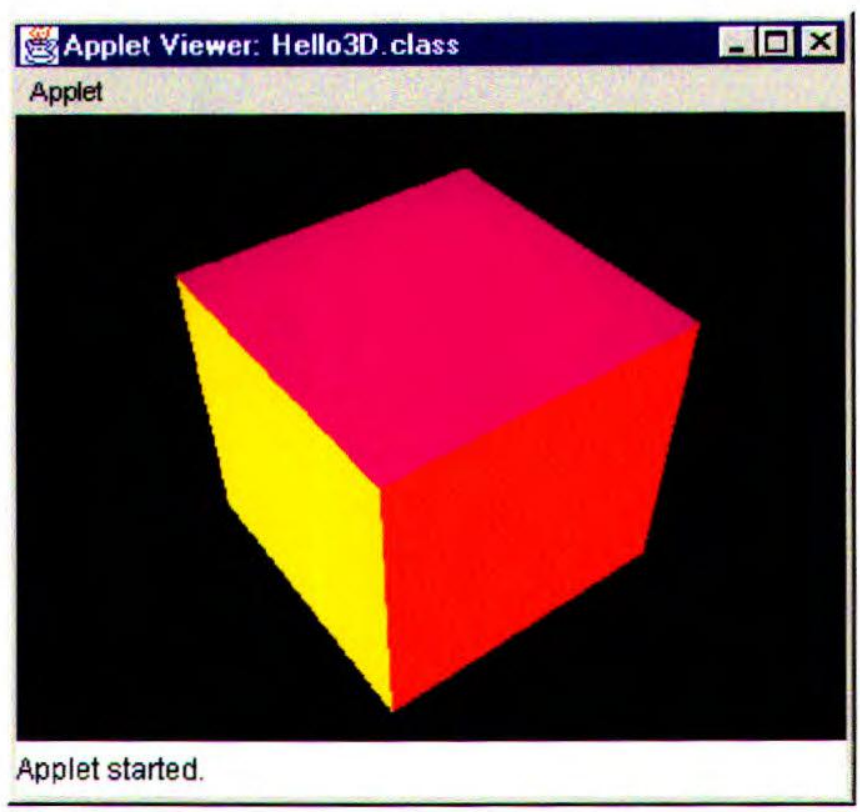

Figura 4.9 - Exemplo de uma visualização usando Java 3D

Uma vantagem significativa de usar Java 3D ao invés de JNI é que as applets de visualização podem ser escritas puramente em Java, sem necessidade de código nativo. Apesar da versão atual do VTK não suportar uma implementação puramente em Java de seus algoritmos de visualização, tal solução será viável se o prometido aumento de desempenho de Java de fato ocorrer. Essa abordagem, como no exemplo anterior, também pode ser enquadrada como um meio termo entre os Cenários 3 e 4 (ver Figura 4.4 e 4.5).

\subsubsection{Visualização usando VRML, Java e a EAI}

A EAI (External Authoring Interface) oferece à VRML a mesma combinação de poder e flexibilidade de Java 3D, por meio de uma interface de comunicação que permite à Java e VRML interagirem entre si [Sch98]. Isso é particularmente útil porque uma applet pode criar um mundo VRML, adicionar e remover nós do grafo de cena e, alternativamente, um grafo de cena VRML pode invocar código Java ou JavaScript em resposta a um evento. De alguma forma, essa solução é similar à que usa Java 3D, com a exceção de que VRML está sendo usada para o rendering, ao invés do mecanismo de rendering de Java 3D. Ambas as soluções têm as vantagens de Java como 
uma linguagem de propósito geral para lidar com a programação e a construção de interfaces com o usuário.

Há várias maneiras de organizar uma visualização utilizando a EAI. O método mais comum é usar uma página HTML que carrega, de forma tradicional, tanto um mundo VRML quanto uma applet Java. Esse cenário é ilustrado na Figura 4.10, sendo que a listagem que descreve a implementação desse exemplo pode ser encontrada em Schroeder et al. [Sch98].

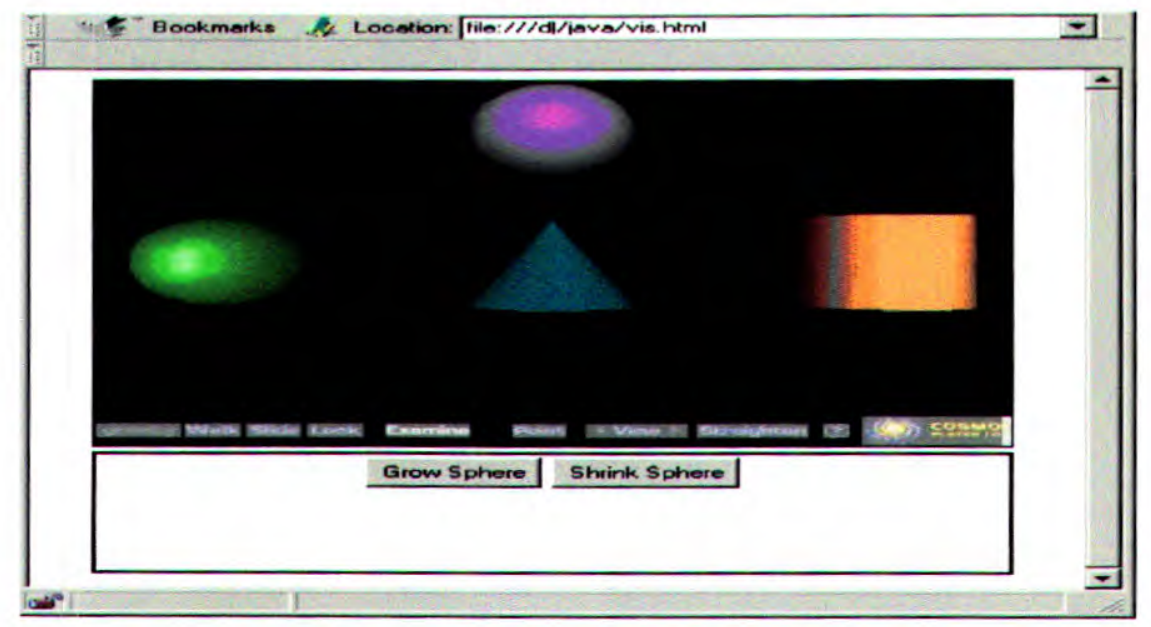

Figura 4.10 - Exemplo de uma visualização usando VRML, Java e EAI [Sch98]

\subsection{Considerações finais}

Neste Capítulo foram apresentados os principais recursos existentes para gerar e disponibilizar recursos de visualização na $W e b$. Há algumas dificuldades, entre as quais o limite de taxa de transmissão pela $W e b$, a falta de familiaridade e dificuldade de interação com modelos 3D, além das limitações de hardware e software existentes atualmente. O sistema VisWeb foi implementado usando applets Java, e é descrito no Capítulo 6, bem como a motivação para a escolha desta tecnologia. No próximo Capítulo é apresentado um estudo sobre a segurança em Java, um fator crítico na implementação de applets de visualização. 


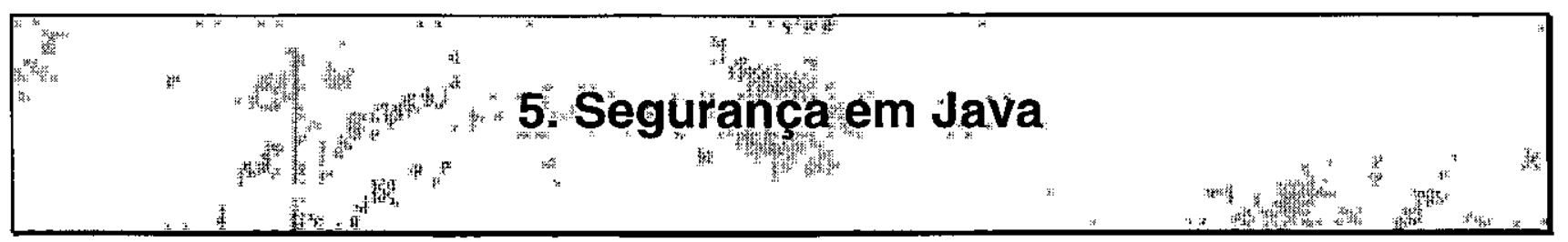

\subsection{Considerações iniciais}

A linguagem Java 1.2 permite que as applets façam tudo o que uma aplicação Java pode fazer, desde que sejam provenientes de um provedor de applets confiável e tenham assinatura digital que permita verificar a sua autenticidade. O sistema VisWeb é composto por três módulos, sendo que cada um é uma applet que implementa uma técnica de visualização. Para implementar os recursos de visualização foi utilizado o VTK, que é um código nativo que deve estar no cliente, exigindo assim que as applets fossem assinadas. Essa foi a principal razão do estudo de segurança em Java.

A segurança em Java é construída sobre três componentes fundamentais do ambiente de execução JRE (Java Run-Tïme Environment): a verificação de bytecodes, a classe ClassLoader e a classe Security Manager [Kov98]. A verificação de bytecodes ocorre quando uma classe Java é carregada; antes de mais nada a JVM verifica a validade dos bytecodes do arquivo que foi carregado. A verificação de bytecodes também controla o acesso aos membros, a checagem de super classes e de argumentos passados como parâmetros aos métodos. Após os bytecodes serem verificados, a classe ClassLoader procura e carrega os bytecodes, a partir da definição das classes. Além disso, ela impede que classes da API de Java sejam carregadas via rede, o que garante que a JVM não estará utilizando falsas representações das bibliotecas de Java.

Provavelmente, a verificação de segurança mais importante é de responsabilidade da classe Security Manager. Sempre que uma aplicação (ou applet) tenta realizar uma operação que pode ser prejudicial ao sistema (por exemplo, escrever no sistema de arquivos), a Security Manager verifica se aquela operação é permitida para a aplicação em questão. No modelo de segurança do JDK 1.2 a Security Manager permite que se estabeleça uma política de segurança, podendo restringir ou liberar recursos para uma aplicação Java. Esse modelo de segurança é apresentado na Seção 5.2 deste Capítulo. Na Seção 5.3 são apresentados alguns conceitos relacionados à segurança de documentos e códigos. Na Seção 5.4 são apresentadas as ferramentas de Java, que permitem criar uma assinatura digital. Na Seção 5.5 é apresentado todo o processo de assinatura de uma applet, e finalmente, na Seção 5.6 é apresentado o processo de execução de uma applet assinada. 


\subsection{A evolução do modelo de segurança de Java}

A linguagem Java tem evoluído muito, em particular visando maior confiabilidade, principalmente, no que se refere ao controle de acesso. O modelo de segurança original oferecido pela linguagem, conhecido como sandbox [Dag99, Gon99, McG99], fornece um ambiente muito restrito para executar um código não confiável obtido da rede. Nesse modelo, ilustrado na Figura 5.1, o código local tem acesso completo aos recursos básicos do sistema (por exemplo, o sistema de arquivos), mas o código remoto que foi descarregado (uma applet) não é confiável e pode acessar somente os recursos limitados disponíveis dentro do sandbox. Esse modelo foi proposto pelo Java Development Kit (JDK) 1.0 e foi amplamente adotado por aplicações construídas com o JDK 1.0, o que inclui browsers com suporte à Java.

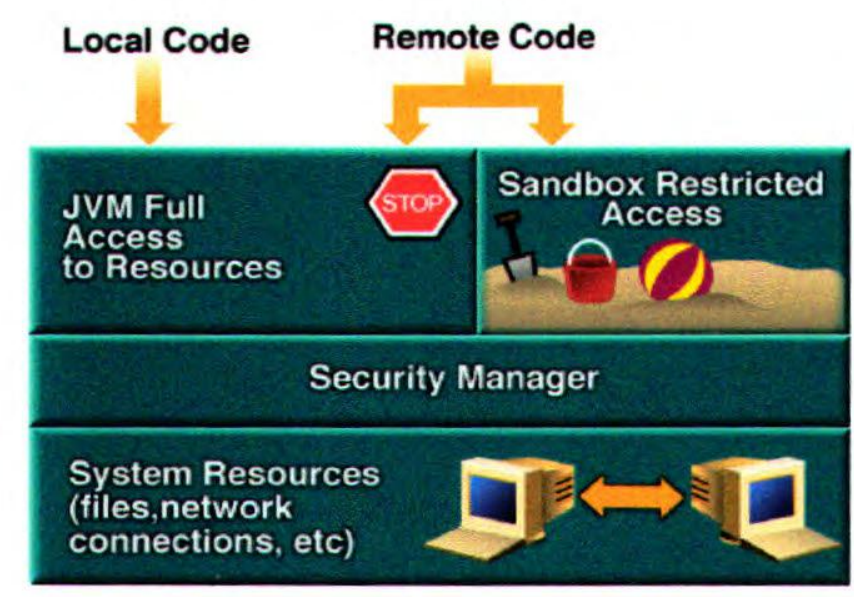

Figura 5.1 - Modelo de segurança do JDK 1.0

O modelo de segurança do JDK 1.1 [Gon97] introduziu o conceito de uma "applet assinada", conforme ilustra a Figura 5.2. Nesse modelo, uma applet assinada digitalmente era considerada como código local, tendo acesso completo aos recursos, desde que a chave pública usada para verificar a assinatura fosse confiável. Por outro lado, as applets não assinadas ainda eram executadas no sandbox. Portanto, esse modelo resolveu parcialmente o problema, pois não existia um meio termo, ou seja, a execução de uma applet era feita sob dois extremos. Se uma aplicação ou applet desejasse adotar uma política de segurança diferente, teria que criar subclasses das classes ClassLoader e Security Manager, e personalizá-las de acordo com sua necessidade. Entretanto, tal prática requer um profundo conhecimento de segurança e pode tornar-se perigosa [Gon99]. 


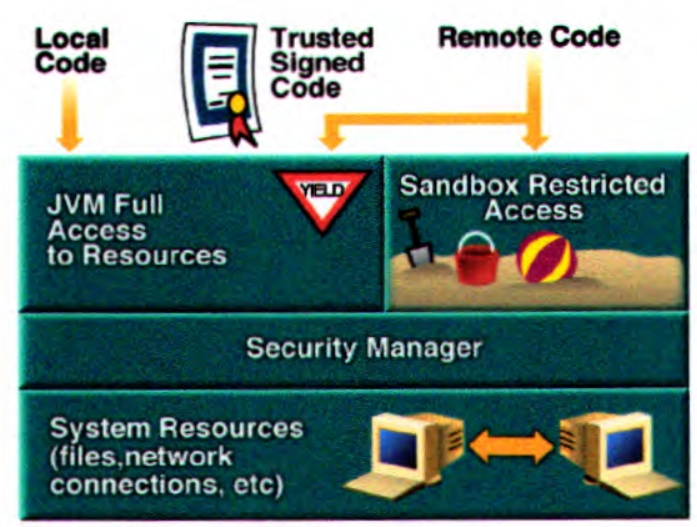

Figura 5.2 - Modelo de segurança do JDK 1.1

A solução veio com o modelo de segurança do JDK 1.2 [Kov98, McG99], que introduziu algumas melhorias em relação à versão 1.1. Primeiramente, todo código, local ou remoto, pode agora estar sujeito a uma política de segurança. Essa política de segurança define um conjunto de permissões, sendo que cada permissão especifica um acesso permitido para um recurso particular como, por exemplo, acesso de leitura para um arquivo.

O sistema runtime organiza os códigos em domínios individuais, em que cada um inclui um conjunto de classes cujas instâncias recebem o mesmo conjunto de permissões. Um domínio pode, por exemplo, ser configurado de maneira equivalente ao sandbox, de forma que as applets sejam executadas em um ambiente restrito, se o usuário ou administrador assim o escolher.

Esse modelo, ilustrado na Figura 5.3, permite definir as restrições de acesso sem necessidade de escrever uma nova classe Security Manager, ou de modificar a plataforma embutida [Kov98]. Assim, as applets descarregadas pelo browser podem adicionar recursos de controle de acesso à JVM sem ter que fazer nenhuma modificação na implementação.

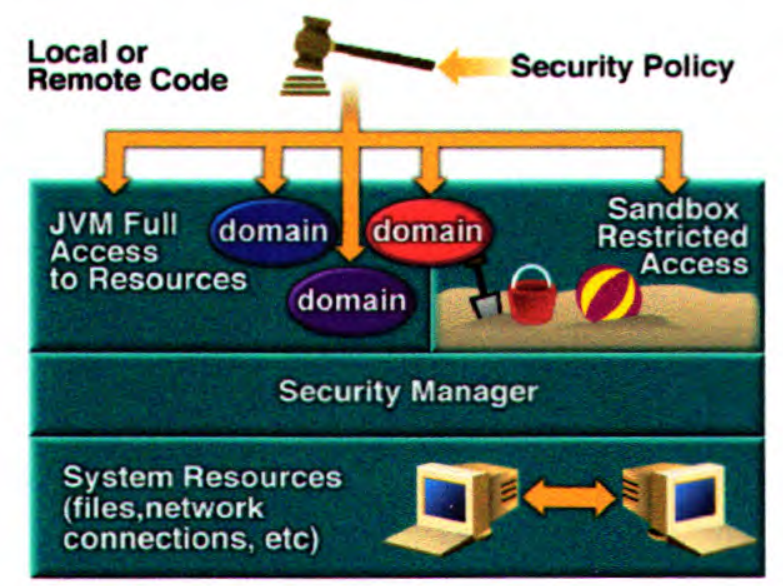

Figura 5.3 - Modelo de segurança do JDK 1.2 
$\mathrm{Na}$ implementação do VisWeb foi utilizado o modelo de segurança do JDK 1.2, devido à sua maior flexibilidade. As Seções seguintes apresentam os recursos de Java 1.2 para o desenvolvimento de aplicações que fazem uso de assinaturas digitais e mecanismos de autorização, os quais foram utilizados no VisWeb.

\subsection{A segurança de documentos e códigos}

A linguagem Java 1.2 permite que um documento (ou documentos), ou uma applet, ou uma aplicação, seja assinado digitalmente e enviado a outras pessoas. Essas pessoas precisam verificar se o documento não foi alterado durante a transmissão (por exemplo, pela interceptação por usuários mal intencionados). Assinaturas digitais e certificados ajudam a garantir a segurança dos arquivos enviados [Dag99].

\subsubsection{Assinaturas digitais}

Para gerar uma assinatura digital, é preciso ter um par de chaves (pública e privada). A chave privada é um número que, supostamente, deve ser conhecido apenas pelo seu possuidor. Ela é sempre associada a uma chave pública, que é um número que pode ser utilizado por uma outra entidade para verificar a assinatura digital gerada com a chave privada.

A função das assinaturas digitais no mundo eletrônico é a mesma das assinaturas no papel do mundo real. Desde que uma chave privada seja conhecida apenas pelo seu possuidor, o uso dessa chave é visto como uma evidência de identidade. Desse modo, se uma mensagem for criptografada com a chave privada de um usuário, pode se deduzir que ela foi "assinada" diretamente por ele.

A seqüência de passos associados ao uso de assinaturas digitais é a seguinte [Dag99]:

1. Assinar o documento, ou código, utilizando uma chave privada, que pode ser gerada pela ferramenta Keytool. Feito isso, deve-se gerar uma assinatura para o documento, utilizando a ferramenta jarsigner. Essas ferramentas são apresentadas na Seção 5.4.

2. Enviar ao receptor o documento e a respectiva assinatura.

3. Fornecer ao receptor a chave pública correspondente à chave privada utilizada para gerar a assinatura, caso o receptor ainda não a tenha.

4. O receptor, por sua vez, deve utilizar a chave pública para verificar a autenticidade da assinatura e a integridade do documento. 
O receptor precisa garantir que a chave pública é autêntica antes de utilizá-la para checar a autenticidade da assinatura. Portanto, é melhor fornecer um certificado (também chamado de certificado de chave pública) contendo a chave pública do que fornecer apenas a chave pública propriamente dita, como discutido na Subseção 5.3.2.

\subsubsection{Certificados}

Os certificados documentam a associação entre chaves públicas e entidades (pessoas, empresas, e assim por diante). São declarações assinadas digitalmente pelo dono autorizado de uma chave privada, dizendo que a chave pública de uma determinada entidade é autêntica. Um certificado inclui, também, informações sobre o dono da chave pública. Um certificado contém, normalmente [Dag99]:

$>$ a chave pública;

$>$ informações sobre a entidade à qual o certificado está associado. Tais informações incluem os seguintes atributos: o nome da entidade, unidade organizacional, organização, localidade, estado ou província, e o código do país.

$>$ a assinatura digital. O certificado é assinado por uma entidade, o emissor, assegurando o fato de que a chave pública inclusa é a verdadeira chave pública de outra entidade, o dono.

$>$ informações distintas sobre o assinante (emissor).

Uma maneira do receptor checar a validade do certificado é pela verificação da assinatura digital do mesmo, utilizando a chave pública do emissor do certificado que pode, por sua vez, estar armazenada em outro certificado emitido por outra entidade, e assim por diante. O processo de verificação poderia parar quando o receptor obtém uma chave pública que ele já considera confiável.

\subsection{Ferramentas para assinatura digital}

Java 1.2 fornece algumas ferramentas para fazer uma assinatura digital, o que possibilita assinar aplicações, applets e qualquer outro tipo de arquivo, até mesmo documentos [Dag99, Kov98, Paw99a]. A ferramenta keytool manipula chaves e certificados, enquanto que a ferramenta jarsigner gera e verifica as assinaturas, que devem ser geradas a partir de uma entrada em um arquivo JAR (Java Archive) que pode, por sua vez, ser gerado com a ferramenta jar. A ferramenta policytool 
permite criar e modificar os arquivos de políticas que definem as suas próprias permissões de acesso aos recursos. Nas Subseções seguintes são apresentadas essas ferramentas.

\subsubsection{A ferramenta jar}

Um repositório de arquivos, ou um arquivo JAR [Som99], é um conjunto de classes Java e de outros arquivos empacotados em um único arquivo. A ferramenta jar permite empacotar e desempacotar arquivos em um arquivo JAR. As entradas de um arquivo JAR podem ser assinadas digitalmente pelo autor de uma applet, ou aplicação. A principal motivação para a criação de arquivos JAR é que as applets e seus componentes, tais como arquivos de imagem e áudio, podem ser descarregados em uma única conexão com o servidor. Isso melhora muito o desempenho, pois não é necessário abrir uma nova conexão para cada arquivo.

Os arquivos JAR podem ser compactados utilizando o formato ZIP, tornando o tamanho do arquivo global menor e, portanto, mais rápido de ser descarregado, embora demore algum tempo, no lado do cliente, para que os arquivos sejam descompactados antes de serem executados. As versões 4.0 e superiores dos browsers Netscape Navigator e Internet Explorer incluem suporte a esse tipo de arquivo. A Listagem 5.1 mostra como criar um arquivo JAR, chamado "Exemplo.jar", empacotando todos os arquivos de classe (.class) e de imagem (.gif) contidos em uma pasta.

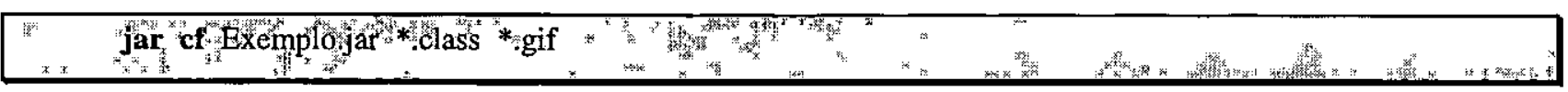

Listagem 5.1 - Exemplo de criação de um arquivo JAR

$\mathrm{O}$ argumento cf especifica duas possíveis opções de linha de comando: a opção c indica que um arquivo JAR deve ser criado, e $\mathbf{f}$ indica que o nome do arquivo JAR acompanhará um dos argumentos seguintes.

\subsubsection{A ferramenta keytool}

A ferramenta keytool [Dag99, Paw99a] é utilizada para gerenciar chaves e certificados. Ela armazena as chaves e os certificados em um keystore, que é um arquivo no qual a chave privada é protegida por uma senha. Ela também permite que usuários administrem seus próprios pares de chaves (pública e privada) e os certificados associados a eles. Existem dois tipos diferentes de entrada em um keystore: 
1. para as chaves: cada entrada armazena a chave privada e o certificado da chave pública correspondente em um formato protegido, para prevenir o acesso não autorizado.

2. para os certificados confiáveis: cada entrada contém um certificado de chave pública pertencente a uma outra entidade. O certificado é dito confiável porque o dono do keystore confia que a chave pública no certificado realmente pertence à entidade identificada pelo certificado.

Todas as entradas do keystore (para chaves ou certificados confiáveis) são acessadas por um único alias. É o alias que identifica o dono das chaves e certificados, sendo que o dono do keystore pode ter várias chaves no mesmo keystore, acessando-as por meio de aliases diferentes.

A ferramenta keytool também pode ser utilizada para [Dag99]:

$>$ criar chaves privadas e seus certificados de chave pública associados;

$>$ emitir pedidos de certificados, os quais devem ser enviados para Autoridades de Certificação apropriadas;

$>$ importar cópias de certificado obtidas da Autoridade de Certificação contatada;

$>$ importar certificados de chaves públicas pertencentes a outras entidades como certificados confiáveis;

$>$ gerenciar o keystore.

A ferramenta também permite gerar certificados self-signed, ou seja, o próprio dono da chave privada garante a autenticidade do certificado contendo a chave pública. Esse tipo de certificado requer que o receptor do JAR conheça e confie na identidade de quem o assinou. Caso contrário, é melhor assinar o certificado por meio de uma Autoridade de Certificação.

\subsubsection{A ferramenta jarsigner}

A ferramenta jarsigner [Dag99, Paw99a] é utilizada para assinar arquivos JAR e para verificar as assinaturas e a integridade dos arquivos JAR assinados.

Para que uma assinatura possa ser gerada devem existir uma chave privada e o certificado da chave pública correspondente. A ferramenta jarsigner utiliza informações sobre as chaves e certificados armazenadas em um keystore para gerar a assinatura. Um JAR assinado contém, entre outras coisas, uma cópia do certificado, extraído do keystore, autenticando a chave pública correspondente à chave privada que foi utilizada para assiná-lo. 
A verificação do arquivo JAR é feita com sucesso se a assinatura for válida e se nenhum dos seus arquivos componentes foi alterado depois da assinatura ter sido gerada. Esse processo não inclui a verificação do certificado da chave pública. Para isso, uma cópia do certificado já deve ter sido importada e comparada ao certificado que chegou com o JAR. É importante ressaltar que a assinatura de um arquivo JAR não garante sua confidencialidade, pois ele pode ser capturado em trânsito e o conteúdo de seus arquivos pode ser lido, ainda que não modificado.

\subsubsection{A ferramenta policytool}

Um arquivo de políticas [Kov98] pode ser criado em um editor de textos simples ou com a ferramenta gráfica policytool [Dag99, Paw99a], ilustrada na Figura 5.4. Com essa ferramenta não é necessário conhecer a sintaxe utilizada nos arquivos de políticas, somente que permissões serão concedidas e a quais entidades, o que reduz sensivelmente a probabilidade de erros.

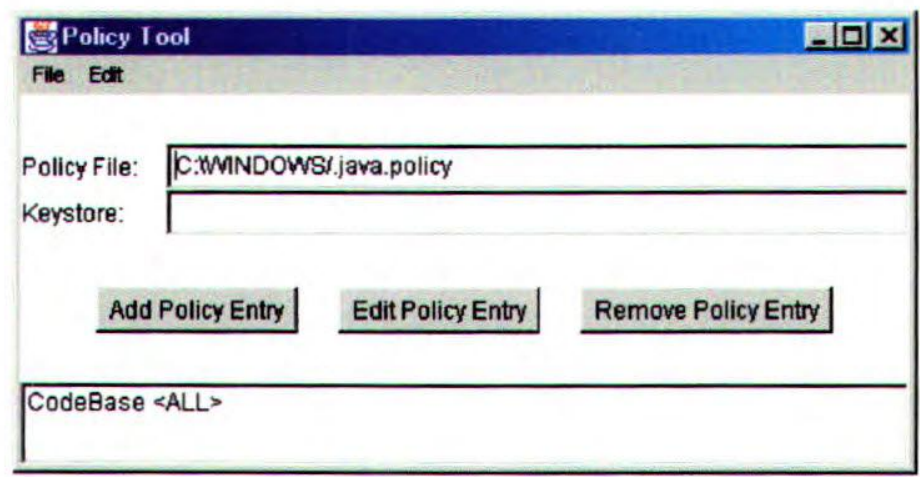

Figura 5.4 - Janela principal da ferramenta gráfica policytool

Um arquivo de políticas pode conter várias entradas, cada uma com duas partes: um CodeSource e uma lista de permissões. O CodeSource também compreende duas partes:

um codeBase indicando a URL do código a ser executado. Se a entrada estiver associada a um CodeBase, as permissões serão concedidas apenas ao código que veio daquela URL.

um signedBy indicando o alias do keystore onde está armazenado o certificado da chave pública correspondente à chave privada que assinou o código a ser executado. É por isso que um arquivo de políticas, geralmente, está associado a um keystore, por exemplo ".keystore". Se a entrada estiver associada ao campo signedBy, serão concedidas as permissões apenas ao código assinado pelo alias correspondente. 
As permissões consistem de uma ou mais entradas, cada qual composta por quatro partes:

$>$ o nome completo da classe de permissão (incluindo o nome do pacote), por exemplo, java.util.PropertyPermission.

$>$ o primeiro argumento para o construtor da permissão, por exemplo, "java.version".

$>$ o segundo argumento é um modificador opcional, por exemplo, "read".

$>$ o último argumento é um nome opcional (o alias) que foi associado ao certificado digital para a classe de permissão.

A Listagem 5.2 mostra um arquivo de políticas, composto de apenas uma entrada, que define algumas permissões de acesso aos recursos do sistema. A primeira permite ler a versão do JDK utilizada, e a segunda permite escrever no diretório que foi especificado, no caso "c://temp" (ambiente Windows). Para referenciar um diretório na definição de uma permissão deve-se usar "II" para ambientes Windows e "P" para ambientes Unix/Linux. Nesse arquivo de políticas, por exemplo, para incluir a mesma permissão de escrita para ambientes Unix/Linux, o diretório especificado seria "/temp".

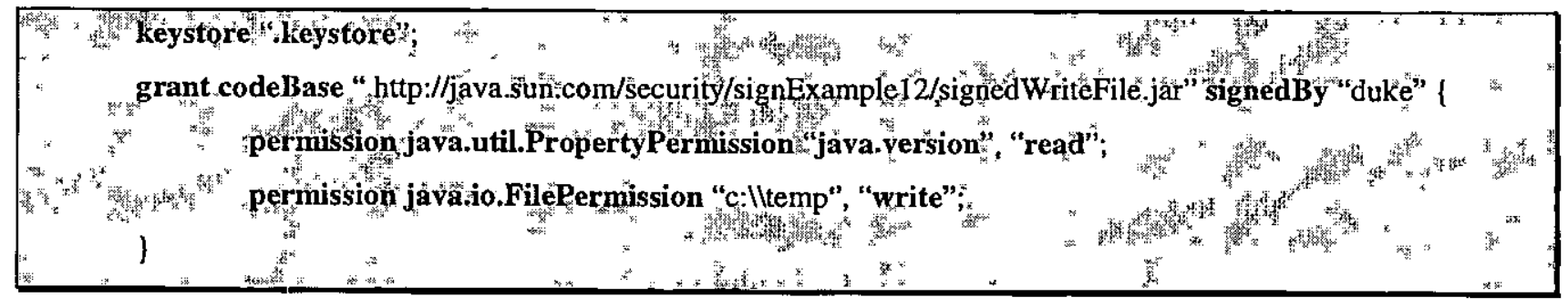

Listagem 5.2 - Exemplo de um arquivo de políticas

Normalmente, um arquivo de políticas é criado com o nome ".java.policy”, e sua localização é especificada no arquivo de propriedades de segurança "java.security", alocado em "java.homelliblsecurityljava.security" no ambiente Windows, e em “java.home/lib/security/java.security" em ambientes Unix/Linux, onde "java.home" indica o diretório em que o JDK foi instalado. É possível criar um arquivo de políticas com outro nome, desde que a sua localização seja especificada no arquivo de propriedades de segurança [Gon99]. Embora possível, isso forçaria o cliente a também especificar a localização quando este fosse executar uma applet assinada que necessite desse arquivo de políticas, tornando a tarefa de execução um pouco mais trabalhosa. 
Com as ferramentas que foram apresentadas é possível assinar uma applet, permitindo que esta tenha acesso a recursos que, normalmente, não teria. Na Seção 5.5 é apresentado todo o processo de assinatura de uma applet [Con99, McG99, Paw99b].

\subsection{Assinatura de applets}

Em virtude das applets serem descarregadas de um site remoto, diversas restrições são impostas, sendo que as assinaturas digitais fornecem um mecanismo para relaxar essas restrições. A Microsoft, a Netscape e a Sun desenvolveram, cada uma, um sistema próprio para a assinatura de códigos Java.

A Microsoft tem ferramentas específicas, e o seu mecanismo permite que as applets assinadas sejam executadas apenas no seu próprio browser, o Internet Explorer. A Netscape também adota um mecanismo que permite que as applets assinadas sejam executadas apenas no seu próprio browser, o Netscape Navigator. Tanto o mecanismo da Microsoft [Bri99, Gri99a, McG99, Vie99a] quanto o da Netscape [Bri99, Gri99b, McG99, Vie99b], requerem um certificado emitido por uma Autoridade de Certificação. Atualmente, as empresas que oferecem esse tipo de serviço cobram uma taxa por essa certificação, que varia de acordo com o tempo de validade da mesma e com as permissões desejadas.

A Sun, na linguagem Java 1,2, oferece algumas ferramentas (apresentadas na Seção 5.4) que permitem estabelecer diferentes níveis de segurança para uma applet, definindo exatamente o que é permitido fazer, além de permitir a criação dos certificados próprios, não havendo a necessidade de se obter um certificado de uma Autoridade de Certificação.

Neste projeto, foi feita a opção pela última maneira, que faz uso da linguagem Java 1.2. Embora, atualmente, a linguagem Java 1.2 não seja suportada diretamente pelos browsers da Microsoft ou da Netscape, o Java Plug-in [And99, Fri99, Sei99, Sun99b] da Sun permite que os projetistas especifiquem uma JVM externa ao browser que suporte applets Java escritas nesta versão da linguagem. Esse processo será melhor explicado na Subseção 5.5.3.

Nas Subseções seguintes será apresentado o processo de assinatura de uma applet usando as ferramentas da linguagem Java 1.2, processo que envolve várias etapas. Primeiro, é necessário criar um certificado (caso ainda não o tenha) com a ferramenta keytool. Feito isso, é possível assinar uma applet Java com a ferramenta jarsigner, e disponibilizá-la para acesso na rede. 


\subsubsection{Criando um certificado}

A ferramenta keytool, entre as suas várias utilidades, permite a criação de certificados self-signed. Na verdade, ela permite criar um keystore que, por sua vez armazena as chaves (pública e privada) e os certificados. A Listagem $\mathbf{5 . 3}$ mostra a sintaxe básica do comando de execução da ferramenta Keytool.

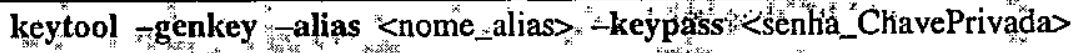

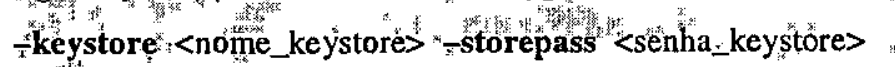

Listagem 5.3 - Exemplo da sintaxe básica da ferramenta keytool

O comando requer algumas informaçōes, como: nome, unidade organizacional, organização, localidade, estado ou província, o código do país referente a essa unidade e, finalmente, é pedida a confirmação para esses dados. Caso algum dado tenha sido fornecido erradamente, basta não confirmar e as informações serão pedidas novamente. Feito isso, será criado um keystore com o nome fornecido em <nome_keystore> no diretório corrente. Se esse nome não for fornecido será criado um keystore com o nome default ".keystore", o qual é alocado no diretório "user.home" que, na plataforma Windows 95'98, pode ser o diretório "c:lwindows", no Windows NT, o diretório "c:lwinntlprofilesWOME_USUARIO" e, no Unix/Linux, o diretório “\$HOME”.

O comando gera um par de chaves (pública e privada) para a entidade fornecida e cria um certificado self-signed que inclui a chave pública e as informações referentes a essa entidade. Esse certificado será válido por 90 dias, que é a validade default, ou pelo período especificado na opção -validity <numero_dias>. O certificado é associado à chave privada na entrada do keystore referenciado pelo alias. A chave privada é associada à senha <senha_ChavePrivada $>$ fornecida na opção -keypass [Dag99].

Uma fragilidade da ferramenta keytool é que o usuário pode aceitar todos os valores default para as informações pessoais pedidas antes da geração do certificado. Nenhuma validação é feita pela ferramenta, que permite, por exemplo, que se crie um certificado para uma entidade qualquer, como Thomas Jefferson. Entretanto, há um conjunto de opções que permite exportar os certificados em um formato adequado para submissão a uma Autoridade de Certificação que pode, então, autenticar esses certificados, caso sejam verdadeiros e confiáveis [Con99]. 


\subsubsection{Assinando uma applet Java}

Para assinar uma applet Java é necessário que duas etapas sejam cumpridas: a primeira consiste em compilar o código fonte (gerar o class), e a segunda, em gerar um arquivo JAR a partir dos arquivos .class gerados.

A compilação de um código fonte Java é feita com a ferramenta javac, que também faz parte do JDK 1.2. A Listagem 5.4 mostra a sintaxe do comando de linha para a execução dessa ferramenta.

Listagem 5.4 - Exemplo da sintaxe da ferramenta javac

O nome do <arquivo_CodigoFonte> fornecido deve ser exatamente igual ao nome utilizado no código, ou seja, é feita a distinção entre caracteres maiúsculos e minúsculos. Feito isso, são gerados todos os .class referentes a este arquivo, que devem ser alocados em um arquivo JAR. A Listagem 5.5 mostra a sintaxe para criar um arquivo JAR.

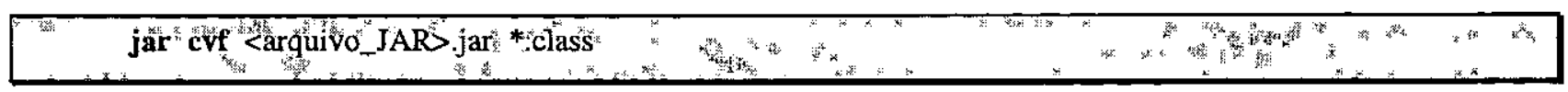

Listagem 5.5 - Exemplo da sintaxe da ferramenta jar

Agora é possível assinar esse arquivo JAR utilizando a ferramenta jarsigner. A Listagem 5.6 mostra a sintaxe de linha de comando para essa ferramenta.

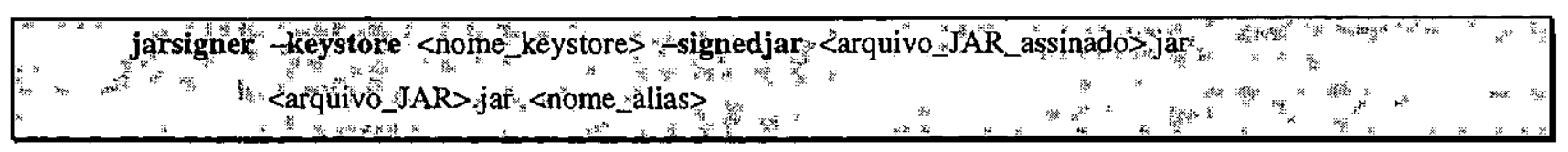

\section{Listagem 5.6 - Exemplo da sintaxe da ferramenta jarsigner}

Esse comando requer a senha <senha_keystore> e a senha <senha_ChavePrivada>, respectivamente e, em seguida, cria o arquivo <arquivo_JAR_assinado>.jar contendo o certificado da chave pública, a partir do arquivo <arquivo_JAR>.jar. Caso o keystore tenha sido criado com o nome default ".keystore", não é necessário informar a opção -keystore. Pode-se, também, informar apenas o arquivo <arquivo_JAR>.jar, sendo que nesse caso esse proprio arquivo será assinado. Para isso não é necessário informar a opção -signedjar. 


\subsubsection{Disponibilizando uma applet Java assinada}

Para disponibilizar uma applet Java assinada é necessário fornecer uma cópia do certificado utilizado para assiná-la, para que o usuário que a acesse possa verificar a autenticidade da assinatura no arquivo JAR. Isso é feito com a ferramenta keytool, que permite exportar uma cópia do certificado contido no keystore utilizado, conforme mostra a Listagem 5.7.

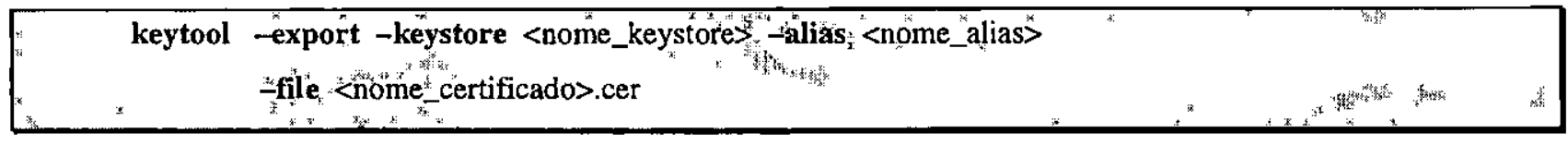

Listagem 5.7 - Exemplo da sintaxe da ferramenta keytool para exportar um certificado

Esse comando requer a senha <senha_keystore>, para que seja criado 0 arquivo $<$ nome_certificado>.cer, contendo o certificado de chave pública. A extensão .cer não é obrigatória, mas ajuda a estabelecer a relação com o arquivo criado. Do mesmo modo que no exemplo anterior, se o keystore foi criado com o nome default ".keystore", não é necessário informar a opção -keystore.

É necessário, também, disponibilizar um arquivo de políticas contendo as permissões necessárias para o acesso a recursos pela applet assinada. Esse arquivo pode ser criado pela ferramenta gráfica policytool (ver Figura 5.4), conforme mostra a Listagem 5.2. Além disso, é necessário criar um documento HTML que inclua a applet assinada para ser acessada por um browser, conforme mostra a Listagem 5.8.

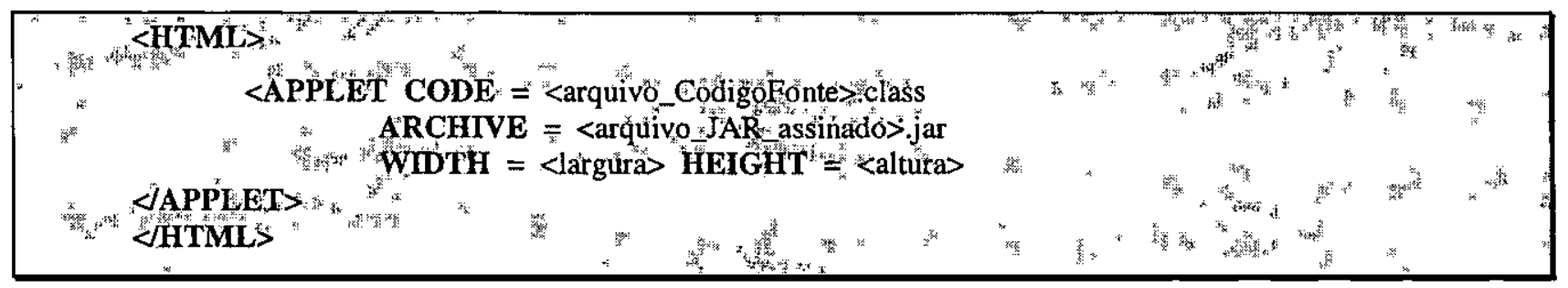

Listagem 5.8 - Exemplo de um documento HTML

Normalmente, isso seria feito da maneira ilustrada na Listagem 5.8. Entretanto, como não existe um browser que suporte a linguagem Java 1.2 e os arquivos JAR assinados por suas ferramentas, é preciso converter os documentos HTML que acessam applets assinadas. Isso pode ser feito em um editor de textos simples, ou com a ferramenta gráfica HTMLConverter [Sch99], conforme ilustra a Figura 5.5. Essa ferramenta, é na verdade, uma aplicação Java. Ela não é fornecida com o JDK 1.2, mas pode ser obtida no site da Sun [Sun96]. 


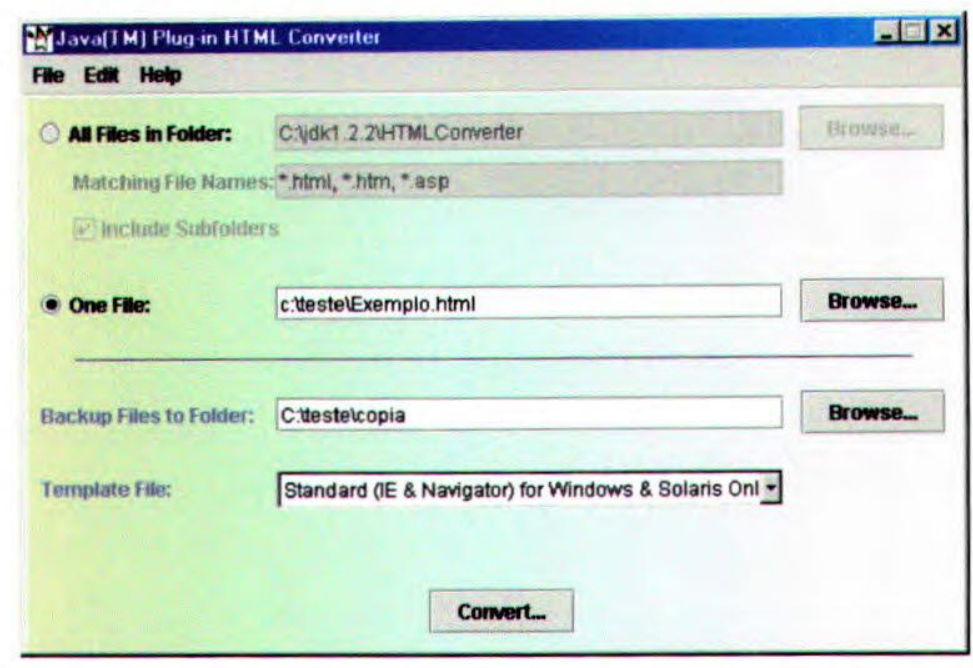

Figura 5.5 - Janela principal da ferramenta gráfica HTMLConverter

Com essa ferramenta é possível especificar um ou mais documentos HTML para serem convertidos, um diretório no qual será feita uma cópia do documentos HTML antes de serem alterados, e também em quais plataformas e browsers os documentos HTML contendo as applets assinadas serão suportados. Feito isso, os documentos HTML convertidos poderão ser acessados pelos browsers especificados na conversão, e as applets assinadas serão suportadas, desde que o Java Plug-in esteja instalado. A Listagem 5.9 mostra um documento HTML convertido, que poderá ser acessado somente pelo browser Netscape na plataforma Windows.

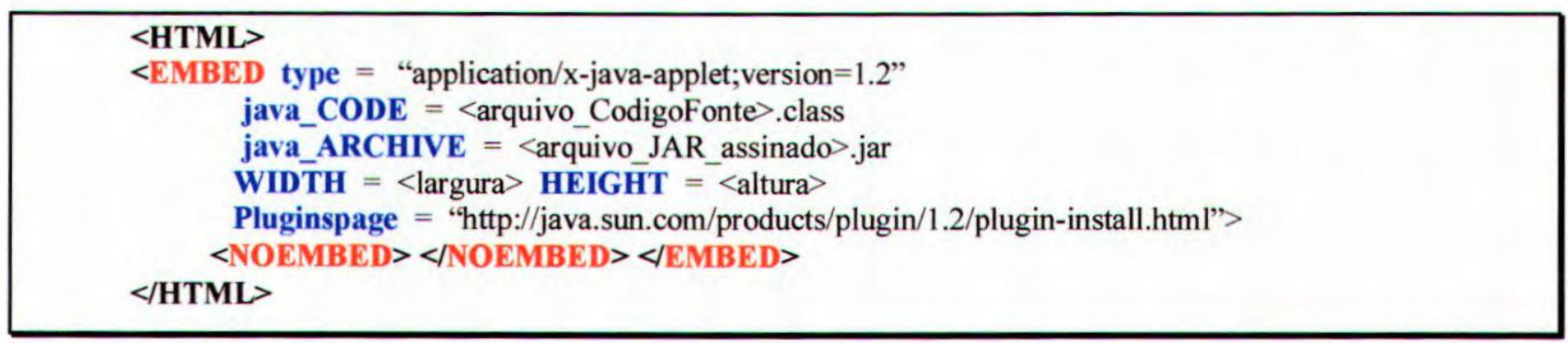

Listagem 5.9 - Exemplo de um documento HTML convertido

Após essas etapas, a applet assinada está acessível a qualquer usuário da $W e b$, desde que seja disponibilizada em um servidor Web. Na Seção 5.6 é apresentado o processo de execução pelo cliente de uma applet assinada [Con99, McG99, Paw99b, Sun99a].

\subsection{Execução de applets assinadas}

Para executar uma applet Java assinada é necessário que o receptor importe o certificado disponibilizado como um certificado confiável em um keystore. O keystore do receptor deve ter a 
chave pública correspondente à chave privada utilizada para gerar a assinatura, de forma que o sistema runtime possa autenticar a assinatura quando a applet for executada. Isso pode ser feito com a ferramenta keytool, conforme mostra a Listagem 5.10.

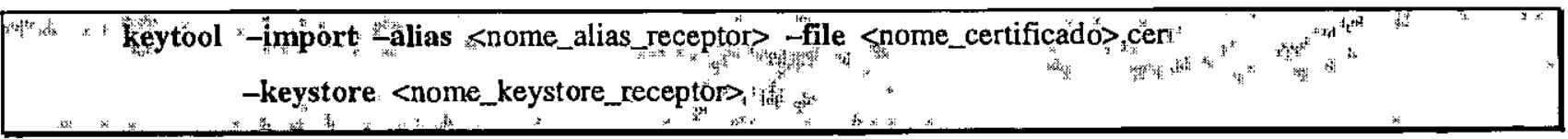

Listagem 5.10 - Exemplo da sintaxe da ferramenta keytool para importar um certificado

Esse comando requer uma senha para o keystore <nome_keystore_receptor>, que pode ser qualquer uma. Também é possível criar o keystore com o nome default ".keystore", não sendo necessário informar a opção -keystore. Se o keystore especificado já existir, o alias <nome_alias_receptor> não deve existir ainda no keystore e deve ser informada a senha usada para criá-lo. Caso isso ocorra, é exibida uma mensagem informando que o certificado <nome_certificado>.cer já existe no keystore especificado sob o alias usado quando o keystore foi criado pela primeira vez e pedida a confirmação para adicioná-lo (é criada uma cópia do certificado no keystore). Caso contrário, são apresentadas as informações do certificado <nome_certificado>.cer, e é pedido para verificá-lo, por exemplo, comparando os fingerprints do certificado recebido com os obtidos de uma outra fonte (confiável) de informação. Cada fingerprint é número relativamente pequeno que realmente identifica o certificado de forma única. Por exemplo, o receptor pode entrar em contato com o dono do certificado e solicitar o fingerprint. Este pode ser obtido, tanto do certificado original, quanto do certificado recebido, executando o comando exibido na Listagem 5.11.

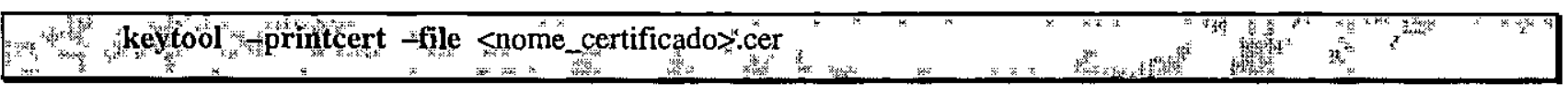

Listagem 5.11 - Exemplo da sintaxe da ferramenta keytool para exibir informações de um certificado

Se os fingerprints do certificado recebido e do original forem iguais, significa que o certificado não foi modificado, e que o receptor pode adicioná-lo a um keystore como um certificado confiável. Um dos problemas de importar o certificado é que o receptor, além de gerar um keystore, deve tomar o cuidado de criá-lo com o mesmo nome especificado no arquivo de políticas a ser descarregado. Uma vantagem é que o receptor tem acesso a informações sobre o dono do certificado, mas elas podem ser falsas, forçando o receptor a checá-las. Entretanto, nada impede que seja disponibilizado o keystore diretamente, já devidamente especificado no arquivo de políticas, facilitando o trabalho do receptor. Essa alternativa também permite obter as mesmas informações do certificado, conforme mostra a Listagem 5.12. Desse modo, pode-se também conferi-los adotando o mesmo 
procedimento usado nos certificados. O VisWeb adota essa política, sendo que assume-se que os seus clientes sabem que se trata de um sistema confiável.

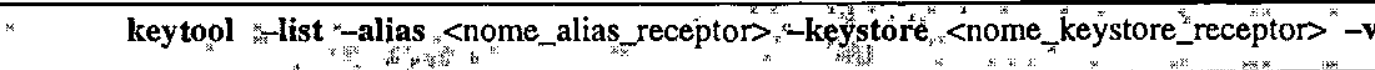

Listagem 5.12 - Exemplo da sintaxe da ferramenta keytool para exibir informaçōes do keystore

Esse comando requer a senha para o keystore <nome_keystore_receptor> que usada para importar o certificado <nome_certificado>.cer, ou a senha usada para criar o keystore. Caso existam vários certificados no keystore, é possível acessá-los por meio do alias correspondente, pela opção -alias. Nesse caso, as informações exibidas, tanto do emissor, quanto do dono do certificado, serão as mesmas para todos os certificados. A diferença será apenas a data e hora em que foram criados, informações que também são exibidas. Essa é uma vantagem de disponibilizar o keystore ao invés do certificado, pois o certificado exibe apenas as suas próprias informações. Se a opção -keystore não for especificada, é necessário que o keystore default ".keystore" esteja no diretório "user.home".

O receptor também deve ter o arquivo de políticas, que contém as permissões necessárias para o acesso a recursos locais pela applet assinada. Caso o receptor tenha gerado um keystore com o nome diferente do que foi especificado no arquivo de políticas, é necessário atualizar o arquivo de políticas. Pode-se, também, informar vários alias no arquivo de políticas, sendo que cada um referese a um certificado adicionado no mesmo keystore, o qual também está especificado no arquivo de políticas. Tanto o keystore criado, quanto o arquivo de políticas obtido, devem ser alocados no diretório "user.home". E, finalmente, para que o receptor consiga executar uma applet assinada, é preciso ter o Java Plug-in instalado para acessá-la por um browser.

Caso, ao invés de uma applet, o receptor estivesse acessando um documento ou uma aplicação Java, ele também deveria ter o arquivo JAR assinado. No caso de uma applet, esse arquivo está embutido no documento HTML criado, e o receptor não tem acesso direto ao mesmo. No caso de um documento ou uma aplicação Java, o receptor pode usar a ferramenta jarsigner para verificar se a assinatura é válida e se o arquivo JAR assinado não foi alterado, como mostra a Listagem 5.13.

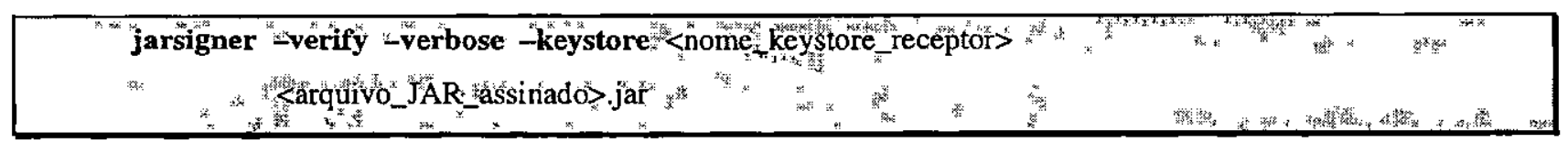

Listagem 5.13 - Exemplo da sintaxe da ferramenta jarsigner para verificar a assinatura de um JAR 
Esse comando exibirá algumas informações relativas ao processo de verificação, tais como o status de cada arquivo contido no arquivo JAR, e se o certificado é ou não conhecido no keystore. Também é possível usar esse comando sem informar a opção -keystore, desde que o keystore default ".keystore" esteja alocado no diretório "user.home".

\subsection{Considerações finais}

O VisWeb é composto por três módulos, sendo que cada um é uma applet que interfaceia com o VTK para implementar as técnicas de visualização. O VTK é um código nativo, ou seja, ele foi desenvolvido em uma outra linguagem, no caso C++. Como o acesso a código nativo é uma das restrições de applets, foi necessário assiná-las para que elas possam fazer uso das bibliotecas do VTK instaladas no cliente. Uma outra razão para assiná-las é que as applets acessam os conjuntos de dados no sistema de arquivos local, sendo que essa é uma outra restrição para applets em geral. No próximo Capítulo é apresentado o VisWeb, ilustrando todas as suas funcionalidades. 


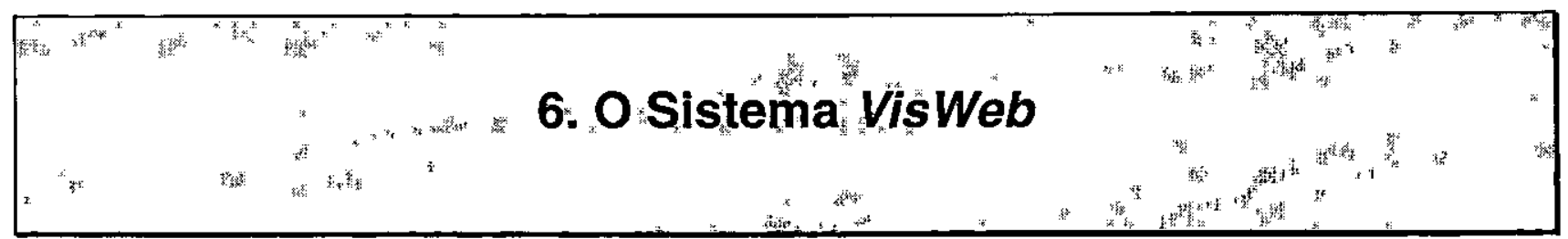

\subsection{Considerações iniciais}

Como uma nova linha de atuação em pesquisa científica, a ViSC ainda está engatinhando, mas o fato é que ferramentas de visualização de dados estão começando a ser tornar acessíveis para instituições acadêmicas, empresas de pequeno porte e mesmo indivíduos, graças à rápida evolução da tecnologia computacional. É nesse contexto que foi desenvolvido o VisWeb, um ambiente de visualização acessível na Web e que utiliza o VTK, uma biblioteca de visualização multiplataforma e de baixo custo.

Este Capítulo descreve a implementação do VisWeb, sendo que na Seção 6.2 são descritas as funcionalidades dos módulos do VisWeb. Na Seção 6.3 descreve-se o procedimento e os recursos necessários para acessar o VisWeb e, finalmente, na Seção 6.4 é apresentada a estrutura organizacional do ambiente, enfatizando alguns detalhes da implementação.

\subsection{Funcionalidade do VisWeb}

O servidor de visualização desenvolvido, denominado VisWeb, interfaceia com o VTK (versão 2.4) para implementar as técnicas de visualização, e oferece uma interface gráfica em Java (versão 1.2.2, sendo totalmente portável para a versão 1.3) para o usuário executar as visualizações desejadas. $\mathrm{O}$ VisWeb é composto por três módulos: um módulo de extração de superfícies, um módulo de rendering volumétrico direto e um módulo de visualização de campos vetoriais, sendo que cada módulo é uma applet Java totalmente independente das demais. Tanto o módulo de extração de superfícies quanto o módulo de rendering volumétrico direto lidam com dados volumétricos escalares, e o módulo de visualização de vetores manipula campos volumétricos vetoriais. Os conjuntos de dados atualmente suportados são malhas estruturadas (structured grids) com geometria e topologia regular, representadas por instâncias da classe vtkStructuredPoints do VTK.

A Figura 6.1 ilustra a estrutura modular do VisWeb, sendo que os nós representam documentos HTML (páginas) que possuem funções específicas, as quais serão discutidas a seguir. 


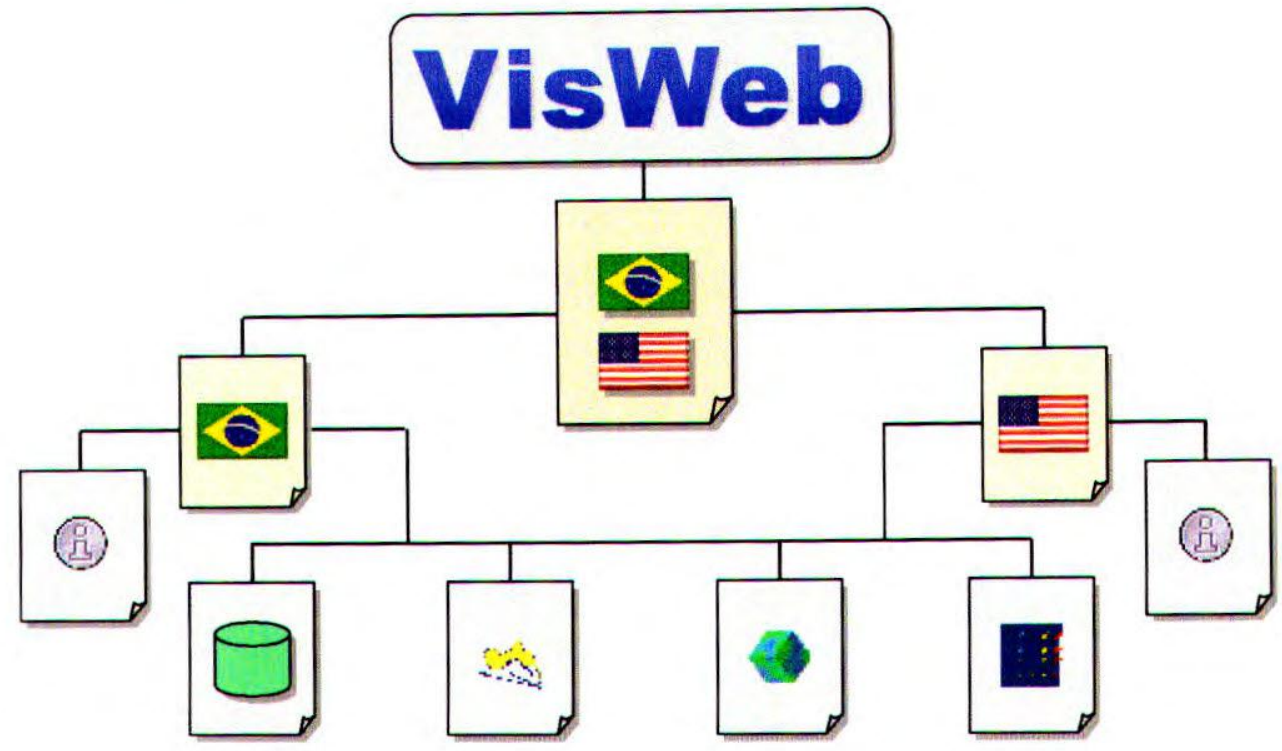

Figura 6.1 - Estrutura do VisWeb

A Figura 6.2 ilustra a janela da página principal exibida quando o VisWeb é invocado. Nessa página é apresentada ao usuário uma janela que permite selecionar o idioma (Português ou Inglês), e a resolução de vídeo é setada automaticamente. Feito isso, o usuário deve clicar no botão "Start VisWeb", para invocar a página seguinte, ilustrada na Figura 6.3, que fornece um conjunto de opções. Na figura, a tela apresentada corresponde à que é exibida se o usuário selecionar o idioma Português.

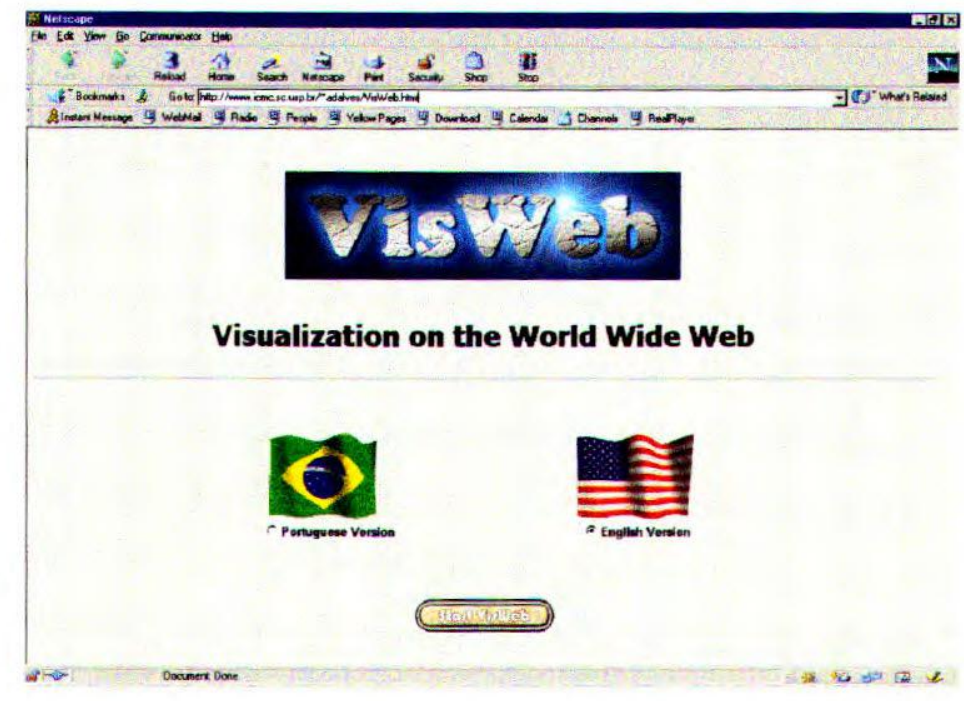

Figura 6.2 - Janela da página principal do VisWeb

A primeira dessas opções, "Informações" ou "Information", oferece ao usuário uma página com informações iniciais para o acesso aos módulos do VisWeb. Na mesma página são disponibilizados os arquivos necessários à execução dos mesmos, que podem ser descarregados pelo usuário (caso 
ainda não os tenha) e instalados na sua máquina. O procedimento será melhor explicado na Seção 6.3. A segunda opção, “Arquivo de Dados" ou "Data File”, permite ao usuário descarregar arquivos de dados disponíveis no servidor. As outras opções dão acesso a cada um dos módulos de visualização já mencionados.

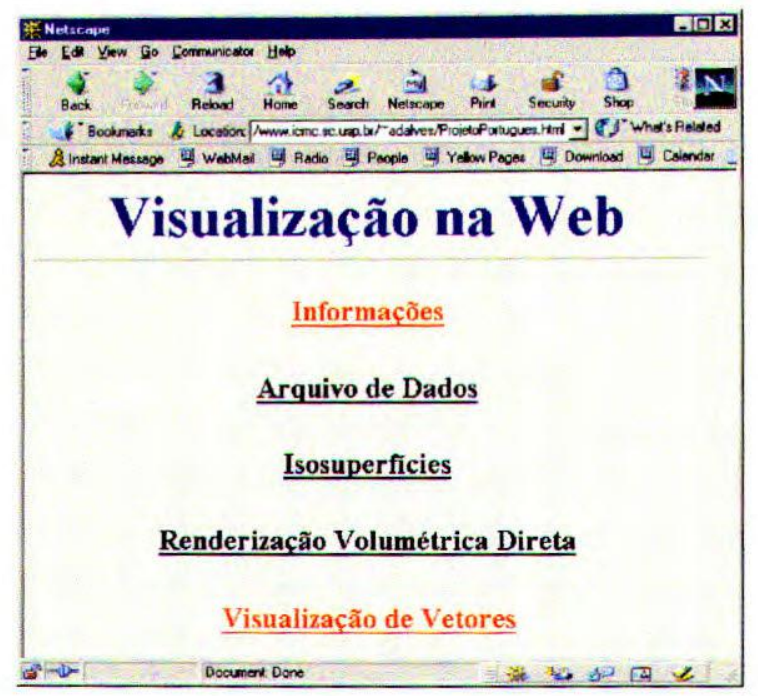

Figura 6.3 - Janela da página para acesso aos módulos do VisWeb

Nas Subseções seguintes são apresentadas as funcionalidades dos módulos do VisWeb.

\subsubsection{Módulo de extração de superfícies}

Este módulo é uma applet Java que interfaceia com o VTK para implementar a técnica de extração de superfícies. As isosuperfícies são extraídas de dados escalares usando a técnica Marching Cubes [Lor87], implementada no VTK pela classe vtkContourFilter. O pipeline VTK completo para extração de isosuperfícies é ilustrado no Apêndice, Figura A.1. No Apêndice também é mostrado o código-fonte de uma applet Java que implementa esse pipeline (ver Listagem A.1). A Figura 6.4 ilustra a estrutura deste módulo mostrando as funções disponíveis em nível de interface com o usuário.

Inicialmente, o usuário deve abrir um arquivo de dados (local). Em seguida, é exibida uma visualização gerada a partir de valores default, os quais são inicializados nas cinco janelas deste módulos, representadas na Figura 6.4 pela cor verde. Opções dessas janelas permitem ao usuário os parâmetros e acionar os botões de rendering correspondentes, representados na figura pela cor cinza. Essas ações vão gerar uma visualização, que é sempre exibida na área principal. 


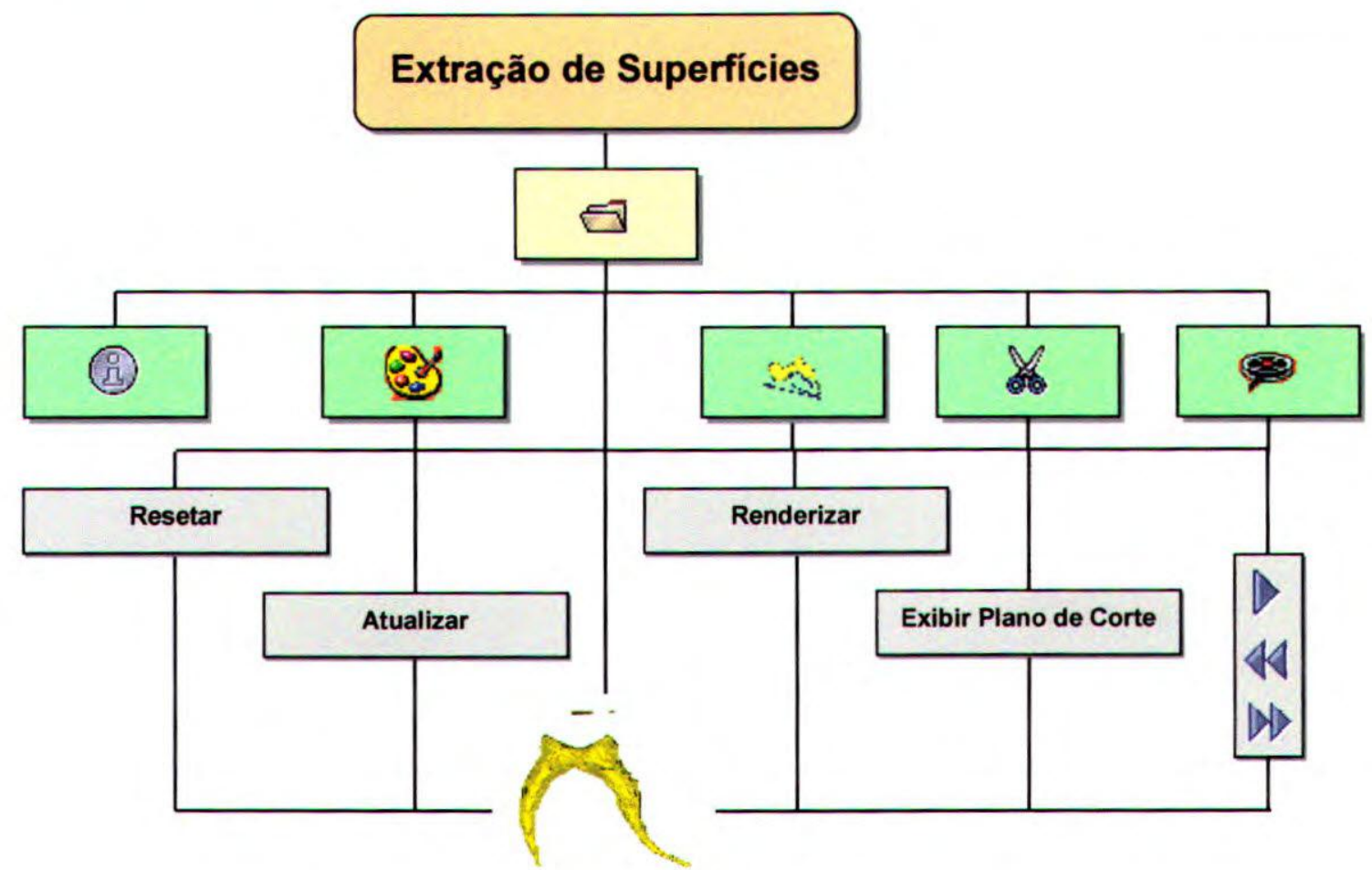

Figura 6.4 - Estrutura da applet de extração de superfícies

A Figura 6.5 ilustra a primeira janela da interface deste módulo, exibida no browser Netscape Navigator. A área de visualização na janela principal, ilustra duas isosuperfícies, uma externa (de cor branca) e uma interna (cor amarela), extraídas de um conjunto de dados escalares que descreve o modelo de um dente. Esse conjunto de dados foi gerado no âmbito do projeto "Visualização no Suporte à Atividades Odontológicas", em desenvolvimento no ICMC (Fapesp proc. 98/12644-8). O processo de definição das isosuperfícies é descrito ao longo dessa Seção.

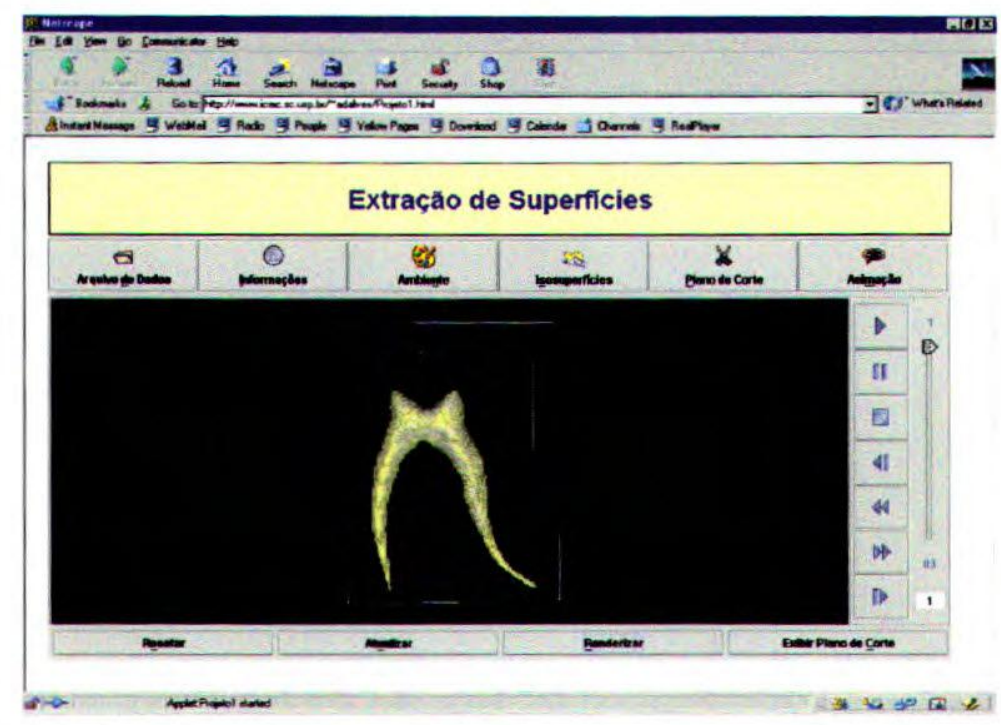

Figura 6.5 - Janela principal da applet de Extração de Superfícies 
Os recursos de todos os módulos podem ser acionados tanto pelo teclado quanto pelo mouse. O botão "Arquivo de Dados" ou "Data File" permite selecionar um conjunto de dados, que deve estar disponível localmente. Quando essa opção é ativada é apresentada uma janela que permite entrar diretamente, via teclado, o nome do arquivo de dados, informando o seu caminho completo, conforme ilustra a Figura 6.6. Feito isso, basta pressionar a tecla $<$ Enter $>$. Caso não seja possível encontrar o arquivo informado será exibida uma janela com uma mensagem de erro, ilustrada na Figura 6.7.

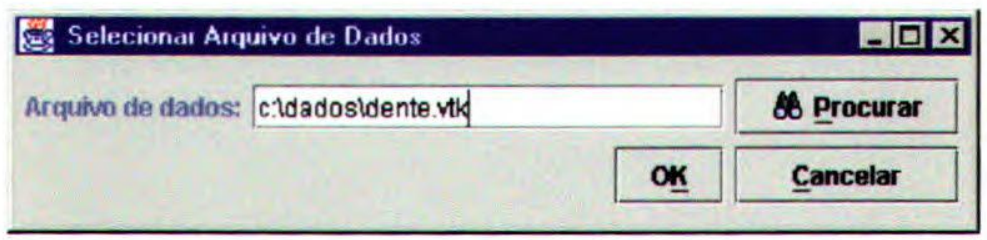

Figura 6.6 - Janela de definição do arquivo de dados

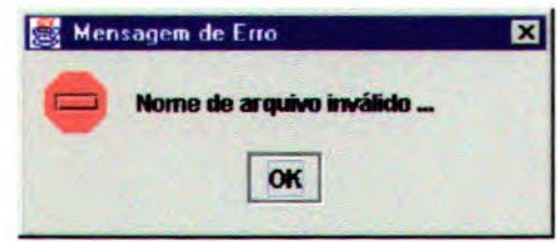

Figura 6.7 - Janela de exibição de mensagens de erro

Pode-se, também, acionar o botão "Procurar" ou "Search" na janela de definição do arquivo, que apresenta uma janela que permite procurar e selecionar um arquivo de dados, conforme ilustra a Figura 6.8.

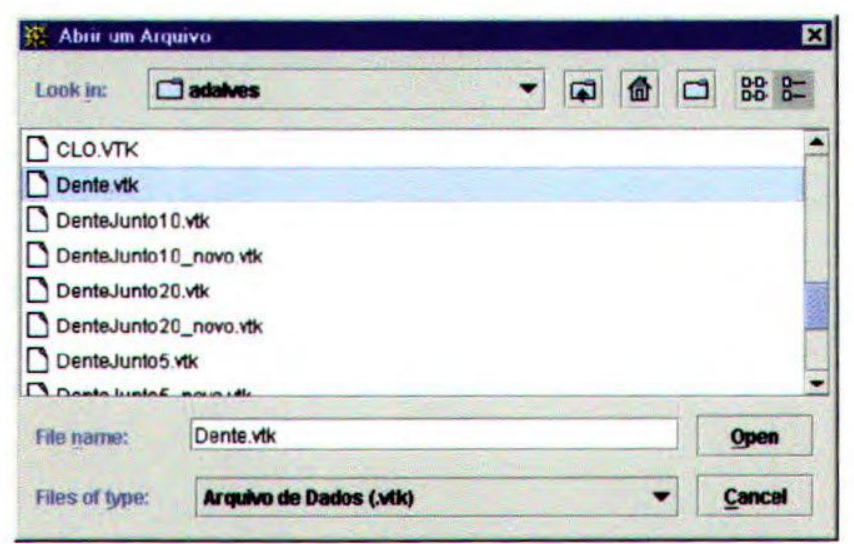

Figura 6.8 - Janela para busca e seleção do arquivo de dados

Somente após a definção de um arquivo de dados que, normalmente, tem a extensão .vtk, é que as demais opções tornam-se ativas. O botão "Informações" ou "Information" exibe uma janela 
contendo informações referentes ao arquivo de dados selecionado, como ilustra a Figura 6.9. Essas informações podem ser necessárias para definir parâmetros em outras janelas deste módulo.

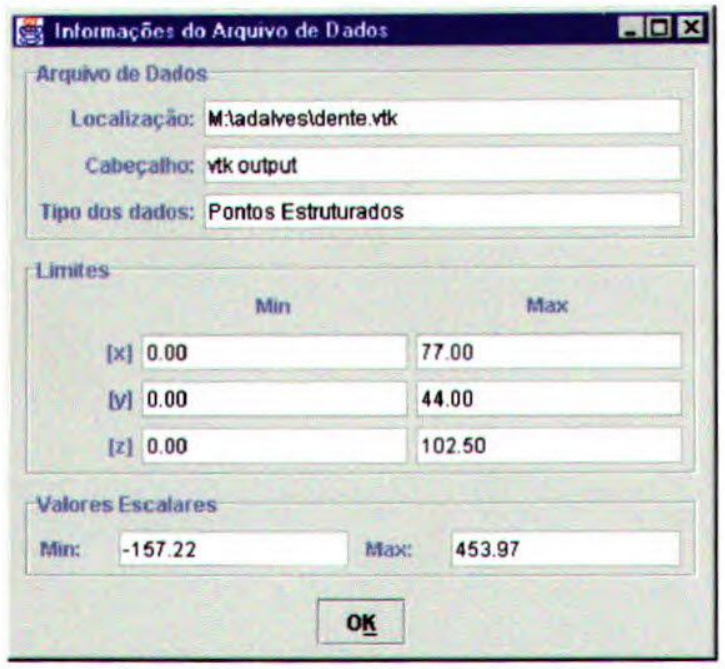

Figura 6.9 - Janela de exibição das informações do arquivo de dados

O botão "Ambiente" ou "Scene" exibe uma janela que permite configurar o ambiente, selecionando o idioma, a cor de fundo da área de visualização (que, por default, é preta), a cor da "borda" exibida em torno do conjunto de dados visualizados, definir se a "borda" deve ser exibida ou não, a cor do texto e de fundo do título na janela principal do módulo. Essas opções são ilustradas na Figura 6.10.

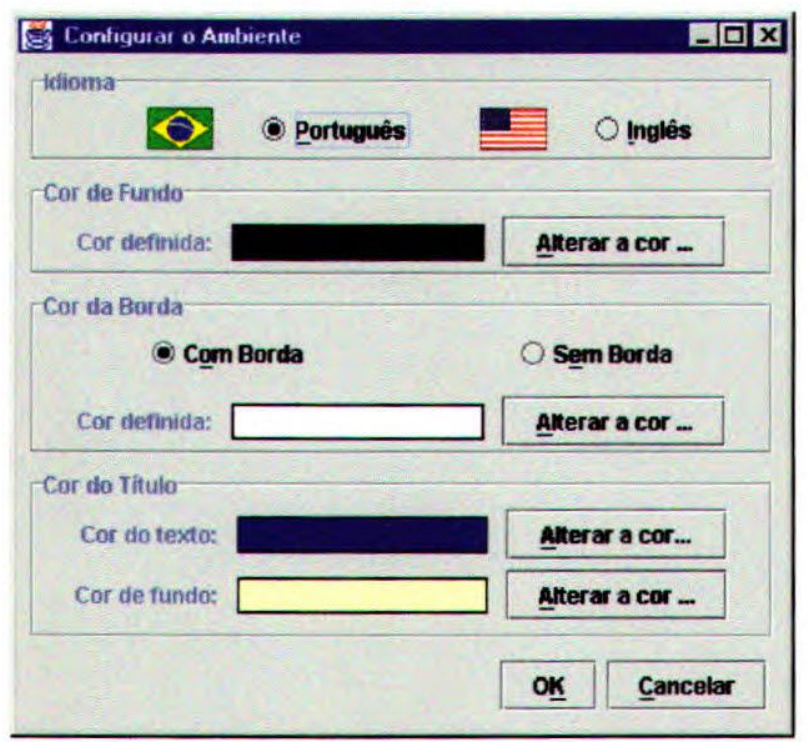

Figura 6.10 - Janela de configuração do ambiente

Para definir uma cor, basta acionar o botão "Alterar a cor ..." ou "Change Color ..." relacionado. Essa opção oferece três formas diferentes para a definição de uma cor, como ilustrado na Figura 
6.11. Dessa forma, o usuário pode escolher a cor segundo o modelo com o qual está mais familiarizado.
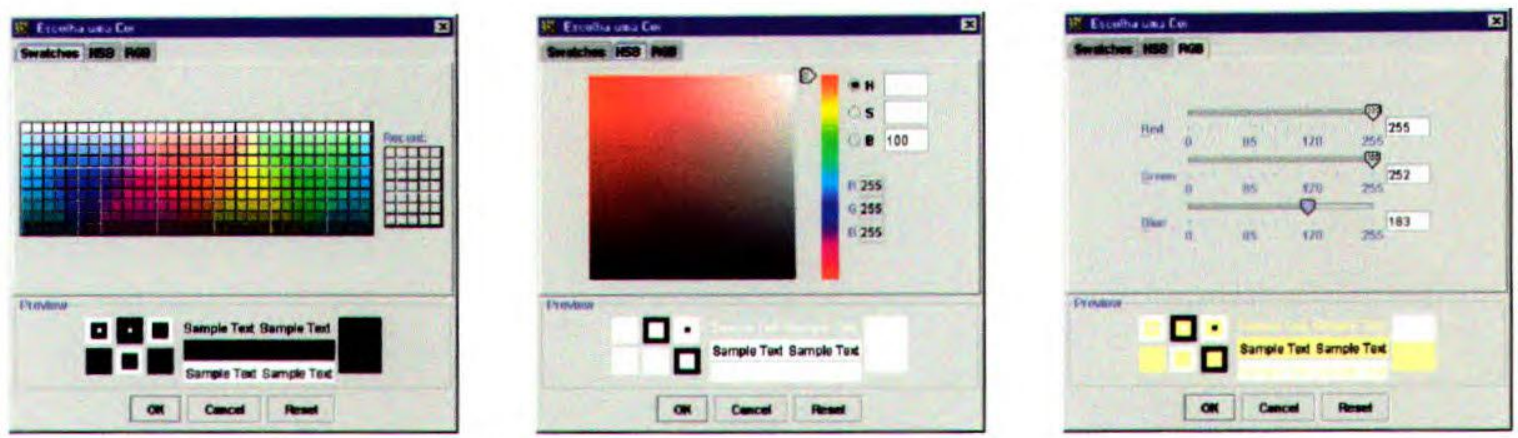

Figura 6.11 - Janelas de definição de cores

O botão "Isosuperfícies" ou "Isosurfaces" exibe uma janela que permite especificar os valores das isosuperfícies e associar uma cor e uma opacidade a cada superfície, conforme ilustra a Figura 6.12. A precisão das barras de rolagem é de duas casas decimais, mas pode-se definir um valor mais preciso diretamente no campo de entrada correspondente. Após selecionar esses valores, basta clicar no botão "Adicionar" ou "Add" para adicionar um valor à tabela de valores definidos, sendo que é possível definir, no máximo, doze valores distintos. Pode-se, também, alterar os valores fornecidos, bastando clicar na célula correspondente da tabela de valores. Também é possível excluir um valor definido, bastando selecionar a linha correspondente na tabela, e acionar o botão "Excluir" ou "Remove", que exibirá uma janela para a confirmação. Para excluir todos os valores definidos, basta acionar o botão "Excluir Tudo" ou "Remove AlI', sendo que também será pedida a confirmação. Caso o usuário deseje cancelar todas as suas entradas ele deve acionar o botão "Cancelar" ou “Cancel' ou, caso contrário, acionar o botão "OK” para confirmá-las. Isso também é válido para as demais janelas deste módulo. Na Figura 6.12 estão definidos os valores de contorno, cores e opacidades usados para gerar a visualização do dente exibida na Figura 6.5. 


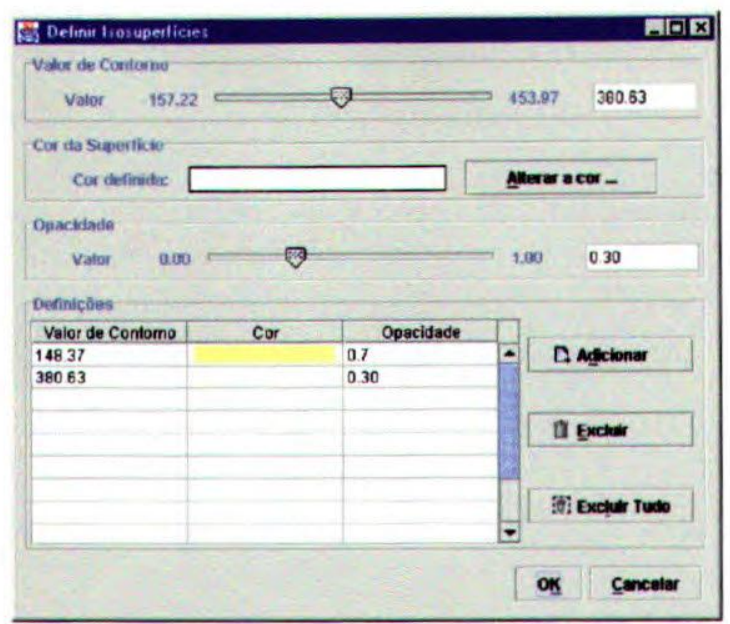

Figura 6.12 - Janela de definição de isosuperficies

O botão "Plano de Corte" ou "Cutting Plane" exibe uma janela que permite definir um plano de corte sobre as isosuperfícies definidas, conforme ilustra a Figura 6.13. Essa opção permite especificar o plano de corte, que pode ser paralelo a XY, $\mathrm{XZ}$ ou YZ, bem como a sua posição no volume de dados.

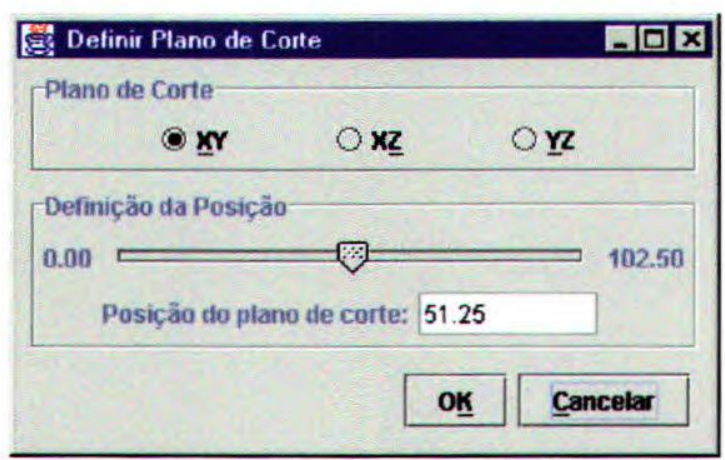

Figura 6.13 - Janela de definição de um plano de corte

O botão "Animação" ou "Animation" exibe uma janela que permite definir uma animação do movimento de um plano de corte sobre as isosuperfícies definidas, ilustrada na Figura 6.14. Essa opção permite especificar o plano de corte, o número de posições do plano de corte a serem exibidos na animação, e a velocidade de apresentação da animação. 


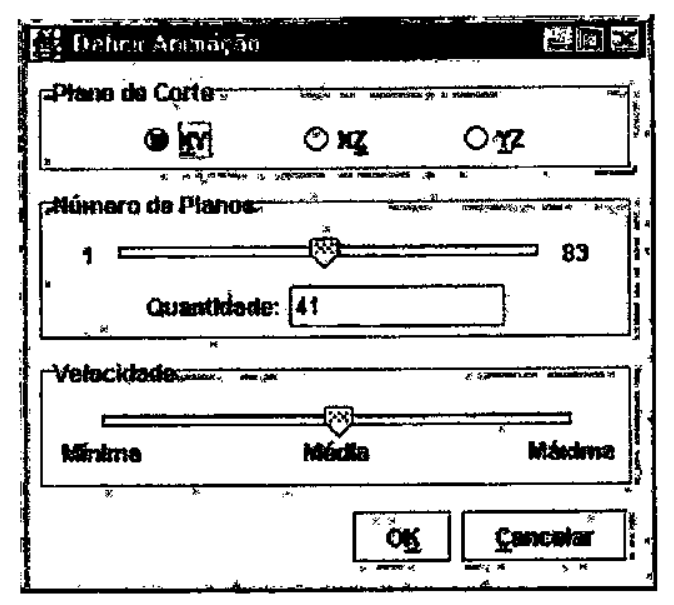

Figura 6.14 - Janela de definição de uma animação

O botão "Resetar" ou "Resef" permite "resetar" o viewpoint, ou seja, a câmera voltará à sua posição inicial. O botão "Atualizar" ou "Update" permite atualizar a exibição do conteúdo atual da janela principal de acordo com os parâmetros especificados na janela de configuração do ambiente (ver Figura 6.10). O botão "Renderizar" ou "Render" causa o rendering de todas as isosuperfícies definidas na janela de definição de isosuperfícies (ver Figura 6.12). Basicamente, essa opção executa o pipeline ilustrado na Figura A.1 do Apêndice. O botão "Exibir Plano de Corte" ou "Show Cutting Plane" ativa o "rendering" do plano de corte definido na janela de definição correspondente (ver Figura 6.13). Essa opção, por sua vez, executa o pipeline ilustrado na Figura A.3 do Apêndice.

Finalmente, os botões (play, pause, stop, stepback, rewind, fastforward e stepforward), localizados à direita da applet, causam a exibição da animação de uma seqüência de planos de corte sobre as isosuperfícies, segundo os parâmetros especificados na janela de definição de animação (ver Figura 6.14). Por meio desses botões, é possível fazer uma pausa (botão pause) na apresentação da animação, alterar qualquer parâmetro e continuar (botão play) a apresentação, sendo que a visualização é atualizada com os novos valores. Também é possível visualizar a animação plano a plano, bem como controlar a exibição pela barra de rolagem localizada à direita da applet (ver Figura 6.5).

Esses são os recursos disponíveis no módulo de isosuperfícies. É válido lembrar que todas as entradas do usuário são verificadas e, quando é encontrado algum erro ou informação inválida, é exibida uma janela com mensagem de erro específica (ver Figura 6.7). Uma outra observação, válida também para os demais módulos, é que a maioria das opções de interação permitidas em uma janela convencional do VTK permanecem operacionais na área de visualização da applet. Isso 
inclui controles para o usuário fazer rotação, zoom e translação nos modelos com o mouse, além de "resetar" o viewpoint, usando os mesmos controles empregados no VTK. A Figura 6.15 ilustra as funções de interação do VTK que estão ativas em Java.

\begin{tabular}{|c|c|}
\hline U. & Descriçấo \\
\hline Tecla ' $r$ ' ou ' $R$ ' & $\begin{array}{l}\text { "reseta" o viewpoint, ou seja, a câmera } \\
\text { volta à sua posição inicial em relação ao } \\
\text { início do último "rendering". }\end{array}$ \\
\hline Tecla 's' ou 'S' & $\begin{array}{l}\text { exibe todos os atores como "surface", ou } \\
\text { seja, eles são tonalizados. }\end{array}$ \\
\hline Tecla 'w' ou 'W' & $\begin{array}{l}\text { exibe todos os atores como "wireframe", } \\
\text { ou seja, eles são tonalizados como "fios } \\
\text { de arame" }\end{array}$ \\
\hline Botões do mouse & $\begin{array}{l}\text { permitem rotacionar (botão esquerdo), } \\
\text { transladar (botão do meio ou <shift>- } \\
\text { botão esquerdo) e fazer zoom nos } \\
\text { modelos (botão direito). }\end{array}$ \\
\hline
\end{tabular}

Figura 6.15 - Funções de interação do VTK operacionais em Java

\subsubsection{Módulo de rendering volumétrico direto}

Este módulo é uma applet Java que interfaceia com o VTK para implementar a técnica de rendering volumétrico direto, permitindo a visualização de dados escalares pelo algoritmo de Ray Casting, implementado no VTK pelas classes vtkVolumeRayCastCompositeFunction e vtkVolumeRayCastMapper. O pipeline VTK completo para rendering volumétrico direto é ilustrado no Apêndice, Figura A.5. No Apêndice também é mostrado o código-fonte de uma applet Java que implementa esse pipeline (ver Listagem A.3). A Figura 6.16 ilustra a estrutura deste módulo mostrando as funções disponíveis em nível de interface com o usuário.

Inicialmente, o usuário deve abrir um arquivo de dados (local). Em seguida, é exibida uma visualização gerada a partir de valores default, os quais são inicializados nas cinco janelas deste módulos, representadas na Figura 6.16 pela cor verde. Nessas janelas, o usuário pode alterar os valores default e acionar os botões de rendering correspondentes, representados na figura pela cor 
cinza. Essas ações vão alterar o modelo exibido na área de visualização. Pode-se, também, especificar um sub-volume, uma tabela de cores e intervalos de intensidade de variação de cor e opacidade. Essas opções são representadas na figura pela cor azul.

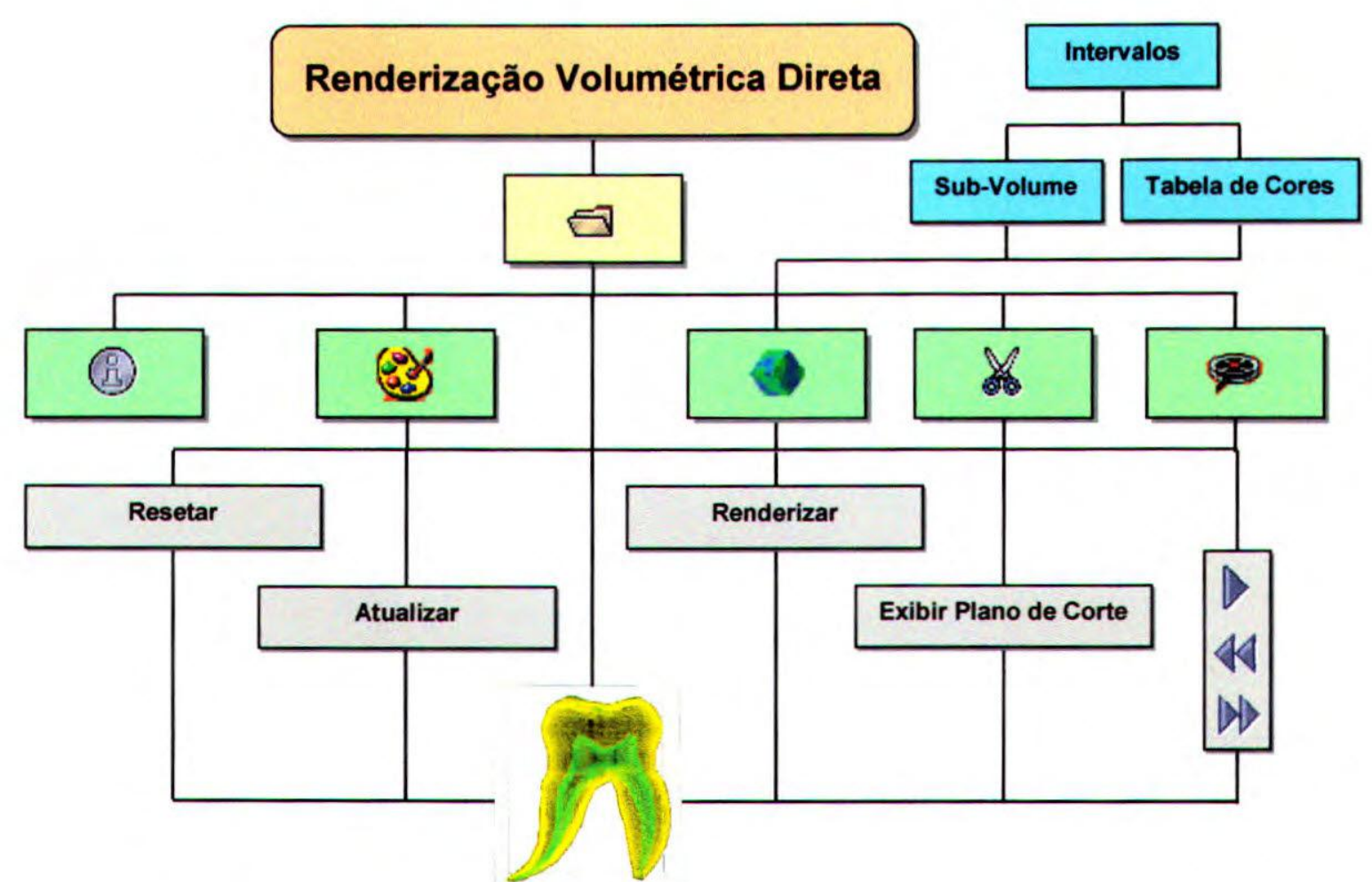

Figura 6.16 - Estrutura da applet de rendering volumétrico direto

A Figura 6.17 ilustra a janela principal da interface deste módulo, exibida no browser Netscape Navigator. A área de visualização na janela principal ilustra um modelo dos dados do dente para o qual foram definidos dois intervalos de variação de intensidade e opacidade. Esses intervalos foram definidos utilizando uma função de mapeamento personalizada, pela qual foi definido um intervalo de cor amarela com uma certa transparência, e outro de cor verde. Esse processo é descrito ao longo dessa Seção. 


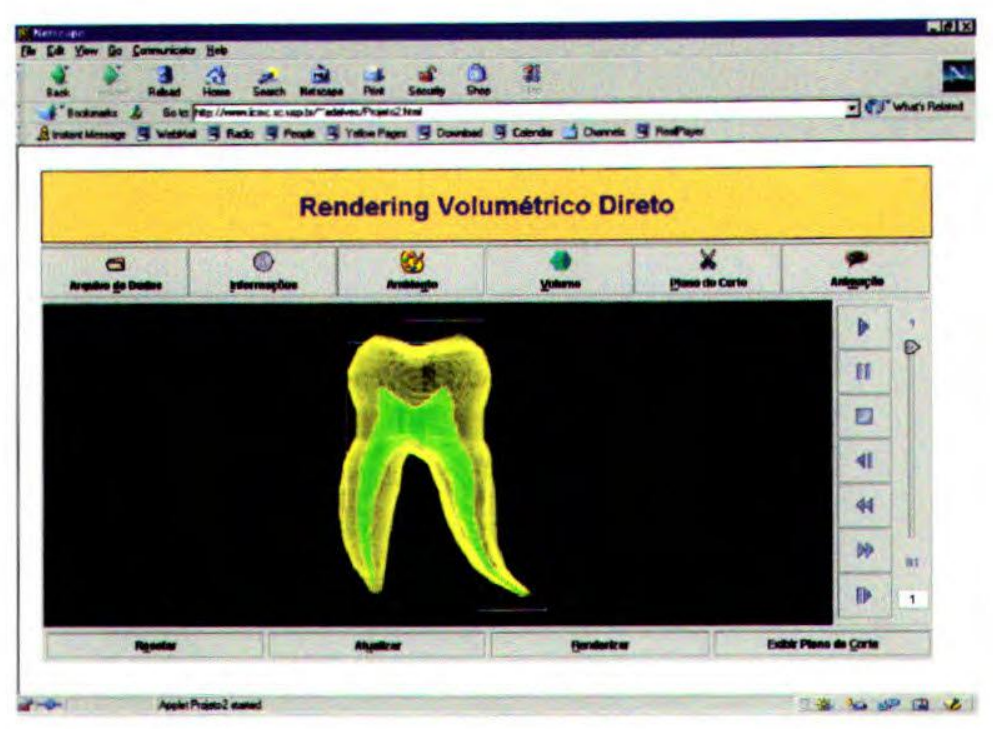

Figura 6.17 - Janela principal da applet de Rendering Volumétrico Direto

Alguns recursos dessa applet são os mesmos utilizados no módulo de extração de superfícies, de forma que os botões “Arquivo de Dados", "Informações", "Ambiente", "Resetar" e "Atualizar", oferecem exatamente as mesmas opções já comentadas. Os botões "Plano de Corte" e "Animação" funcionam de maneira análoga à do módulo de isosuperfícies, exceto pelo fato de que os valores (mínimo e máximo) para a definição da posição do plano de corte, e do número de posições do plano de corte, respectivamente, são alterados de acordo com a região especificada, "Volume Inteiro" ou "Sub Volume". Nesta Subseção são discutidos somente os recursos diferenciados em relação ao módulo de extração de superfícies.

O botão "Volume" exibe uma janela que permite escolher entre visualizar todo o volume de dados ou, alternativamente, um sub-volume do mesmo, sendo que os campos de entrada para definição de um sub-volume somente ficam ativos quando essa opção está selecionada. Isso é ilustrado na Figura 6.18. Para o DVR, é necessário classificar o material contido no volume mapeando intervalos de valores de dados em cores e opacidades. Nessa mesma janela são definidos os parâmetros iniciais para esse mapeamento. 


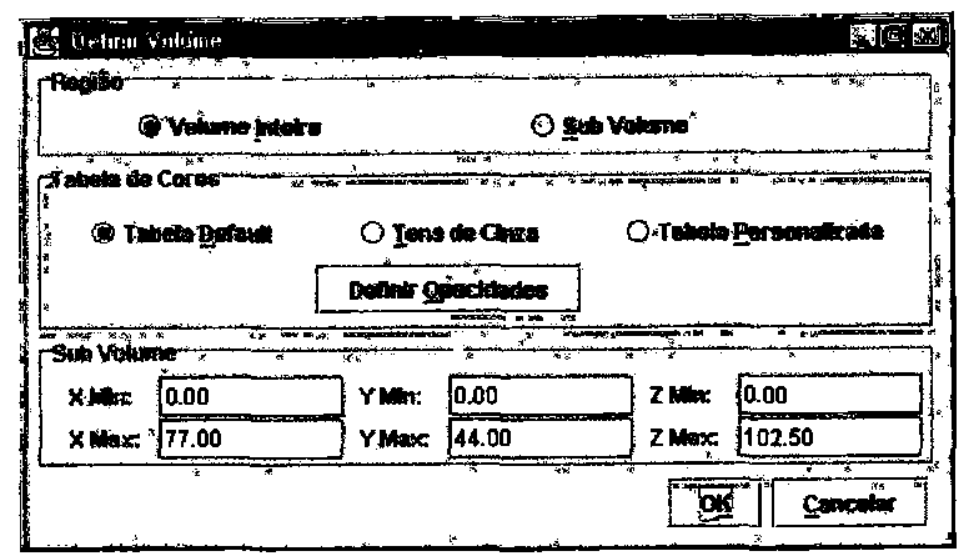

Figura 6.18 - Janela de definição de um volume

Para definir a "tabela de cores" a ser usada na classificação dos dados do volume o usuário deve selecionar uma das opções disponíveis (Default, Tons de Cinza ou Personalizada) e acionar o botão "Definir Opacidades" ou "Define Opacities". Caso sejam escolhidas a tabela default, ou a tabela de tons de cinza, o usuário só precisa definir as opacidades, pois a função de mapeamento de cor é criada mapeando linearmente o intervalo dos dados segundo a escala de cores do arco-íris (default) ou segundo a escala de tons de cinza. Para a definição de opacidades é apresentada a janela ilustrada na Figura 6.19, que permite definir os valores iniciais e finaîs de um intervalo de valores de dados e as opacidades inicial e final para esse intervalo. A opacidade no intervalo varia linearmente a partir do valor inicial definido até o valor final definido.

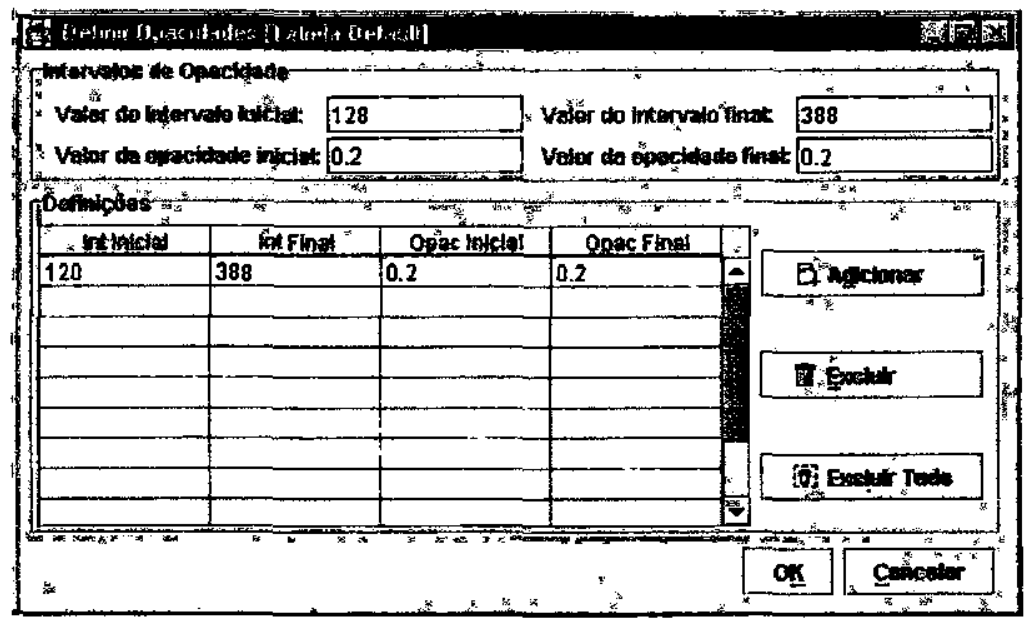

Figura 6.19 - Janela de definição de intervalos de opacídade utilizando uma tabela default

Essa janela permite especificar no máximo doze intervalos disjuntos de variação de intensidade e opacidade. Os botões "Adicionar", "Excluir" e "Excluir Tudo" oferecem os mesmos recursos já descritos na Subseção 6.2.1. 
A Figura 6.20 ilustra a janela para definição de uma tabela de cores personalizada. Essa tabela permite ao usuário definir funções de transferência de cor e de opacidade arbitrárias para a classificação do material contido no volume. Para cada intervalo, são especificados valores de cor e de opacidade inicial e final, e a variação é linear dentro do intervalo. Esses intervalos são associados a uma função de transferência de cor e opacidade que, se definida de forma adequada, isto é, se a classificação de dados for apropriada, o rendering volumétrico direto permitirá visualizar detalhes no interior do volume que seriam difíceis de observar utilizando extração de superfícies.

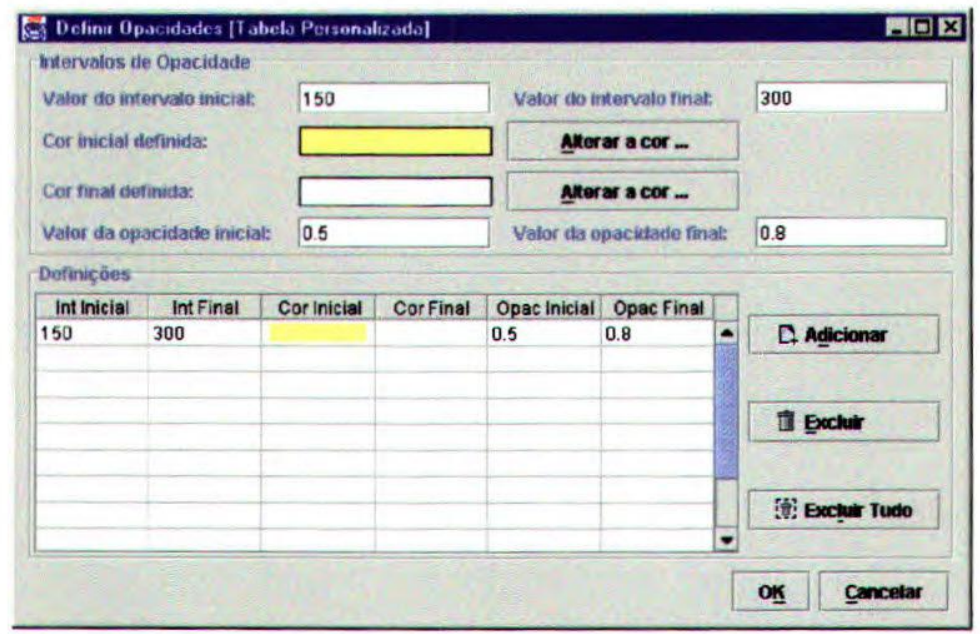

Figura 6.20 - Janela de definição de intervalos de opacidade utilizando uma tabela personalizada

O botão "Renderizar" (ver Figura 6.17) causa o rendering do volume ou sub-volume segundo a tabela definida, dependendo do que foi especificado. Essa opção executa o pipeline ilustrado na Figura A.5 do Apêndice para o volume, ou o pipeline ilustrado na Figura A.7 caso tenha sido especificado um sub-volume. O botão "Exibir Plano de Corte" ativa o "rendering" do plano de corte definido na janela de definição correspondente. O plano de corte exibido é, na verdade, um sub-volume do volume original com as mesmas dimensões do volume original em duas das direções, e com espessura igual a uma fatia na terceira direção. Essa solução é uma aproximação para a implementação do conceito de plano de corte aplicado às superfícies. Esse conceito não foi usado diretamente porque o mapeamento de cores em volumes é feito pela definição de uma função de transferência, enquanto que para planos de corte ele é feito pela definição de uma tabela de cores (lookup table), e não foi possível gerar uma tabela de cores compatível com a função de transferência aplicada no volume. O botão "Animação" e os controles correspondentes de animação causam a exibição da animação de uma seqüência de "planos de corte" sobre o volume ou sub-volume definido. 


\subsubsection{Módulo de visualização de vetores}

Este módulo é uma applet Java que interfaceia com o VTK para implementar a técnica de visualização de vetores. A applet recebe como entrada um arquivo de dados estruturado que descreve um campo vetorial tridimensional, e produz uma visualização baseada em glyphs usando segmentos de reta. Essa técnica é implementada no VTK pelas classes vtkMaskPoints, vtkVectorNorm e vtkHedgeHog, e o pipeline VTK completo é ilustrado no Apêndice, Figura A.10. No Apêndice também é mostrado o código-fonte de uma applet Java que implementa esse pipeline (ver Listagem A.6). A Figura 6.21 ilustra a estrutura deste módulo mostrando as funções disponíveis em nível de interface com o usuário.

Inicialmente, o usuário deve abrir um arquivo de dados (local). Em seguida, é exibida uma visualização gerada a partir de valores default, os quais são inicializados nas três janelas deste módulos, representadas na Figura 6.21 pela cor verde. Nessas janelas, o usuário pode alterar os valores default e acionar os botões de rendering correspondentes, representados na figura pela cor cinza. Essas ações vão atualizar a visualização exibida na área de visualização.

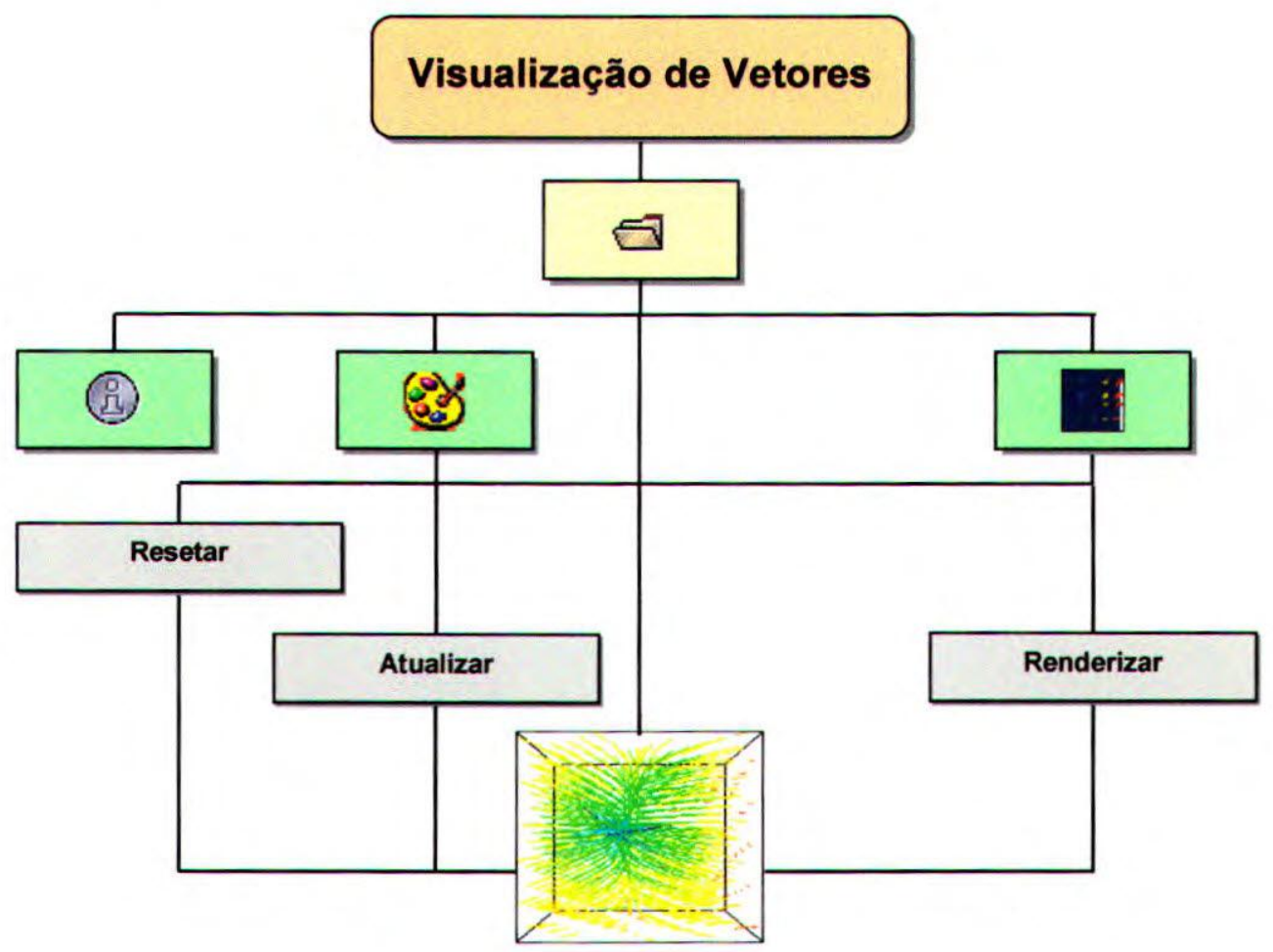

Figura 6.21 - Estrutura da applet de visualização de vetores

A Figura 6.22 ilustra a janela principal da interface deste módulo, exibida no browser Internet Explorer. A área de visualização ilustra uma visão dos dados vetoriais de um campo magnético em 
torno de um modelo de célula neuronal artificial criado pelo Grupo de Visão Cibernética do IFSC [Cos00].

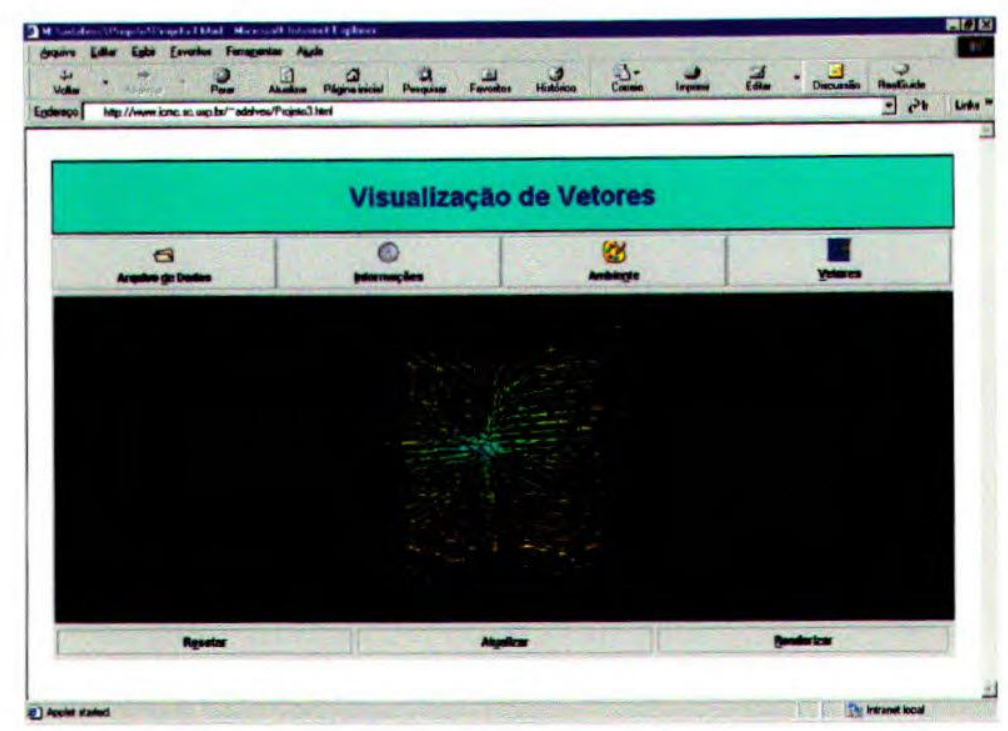

Figura 6.22 - Janela principal da applet de Visualização de Vetores

Alguns recursos dessa applet são os mesmos utilizados nos módulos anteriores, de forma que os botões “Arquivo de Dados", "Informações", “Ambiente”, "Resetar" e "Atualizar" oferecem as mesmas opções já comentadas. O botão "Vetores" ou "Vectors" exibe uma janela que permite especificar parâmetros tais como a taxa de amostragem para controlar o número de glyphs exibidos, o número máximo de pontos do volume a serem exibidos e um ponto inicial. Pode-se, também, definir o modo de seleção dos pontos que, por default é o "Modo Normal". Caso seja definido o "Modo Aleatório" deve-se informar a taxa de amostragem para o modo aleatório, de forma que, toda vez que o botão "Renderizar" for acionado, é exibida uma visualização diferente. O mapeamento das magnitudes dos vetores em cores é feita segundo uma tabela de cores default (ver Listagem 2.1). Todas essas opções são ilustradas na Figura 6.23. O botão "Renderizar" causa o rendering dos vetores segundo as opções feitas na janela de definição correspondente. 


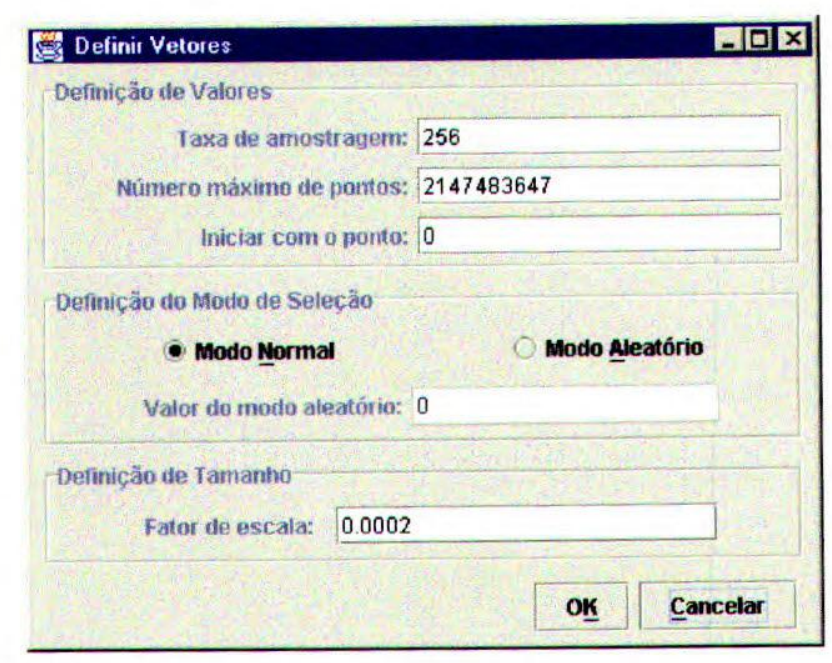

Figura 6.23 - Janela de definição de vetores

\section{j.3. Informações para acesso}

'ara que as applets funcionem adequadamente no cliente, alguns arquivos e bibliotecas devem estar disponíveis localmente. Esses arquivos podem ser descarregados a partir da segunda página de acesso ao VisWeb (ver Figura 6.3) ativada quando é acionada a opção "Informações" ou "Information". A página que exibe as informações e disponibiliza os arquivos necessários é ilustrada na Figura 6.24.

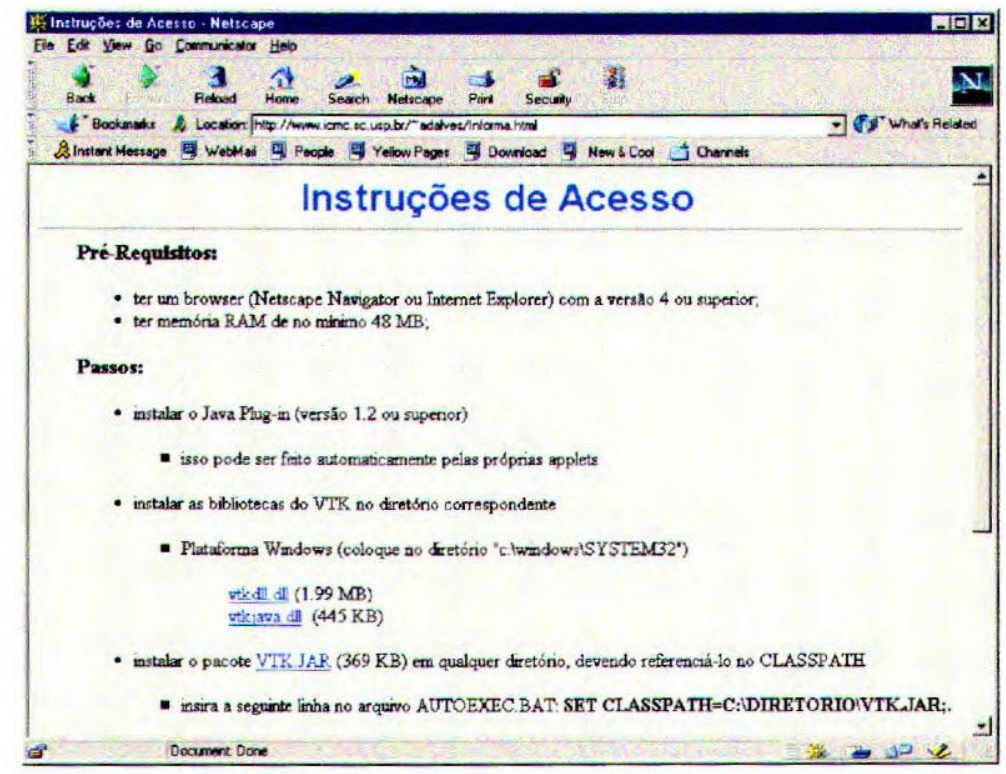

Figura 6.24 - Janela da página para acesso às informações iniciais

Os clientes devem ter o Java Plug-in instalado (versão 1.2 ou superior) para executar os módulos do VisWeb. Isso porque esses módulos utilizam recursos que ainda não são oferecidos por browsers 
que suportam a linguagem Java. Dessa forma, é a JVM do Java Plug-in que suporta os módulos do VisWeb. Nessa página há um link para o site da Sun, que permite descarregar o Plug-in, sendo que isso é feito automaticamente pelo VisWeb quando o Plug-in não é encontrado. Ele está disponível para várias plataformas, mas, atualmente, a versão para Linux é fomecida por uma organização chamada Blackdown, sendo que no site da Sun há um link para essa organização (acessível em http://www.blackdown.org/).

Deve-se, também, ter disponíveis as bibliotecas do VTK apropriadas, especificamente os arquivos "vtkdll.dll" e "vtkjava.dll", devidamente instalados no diretório apropriado que, no caso do ambiente Windows, pode ser o "c:IwindowsISYSTEM32". No Windows, as classes do VTK para Java (as quais estão no pacote "vtk.jar") acessam as bibliotecas "vtkdll.dll" e "vtkjava.dll". No Unix/Linux devem existir as bibliotecas correspondentes, no caso "libVTKdll.so" e "libVTKJava.so". Entretanto, o processo de compilação do VTK (versão 2.4) para Linux gera vários so's distintos (libVTKCommonJava.so, libVTKGraphicsJava.so, libVTKImagingJava.so, libVTKContribJava.so e libVTKPatentedJava.so). Possivelmente, será necessário alterar as chamadas das classes do VTK para Java, gerando um novo pacote para o Linux, ou estudar uma forma de alterar o processo de compilação do VTK para gerar apenas as duas bibliotecas correspondentes. Por essas razões, atualmente, somente as $d l l$ 's estão disponíveis para download na página do VisWeb, mas em breve também estarão os so's. Nessa página, as dll's correspondem às da versão 2.4 do VTK, que foi usado no VisWeb. Versões atualizadas do VTK podem ser encontradas na página da Kitware, Inc. http://www.kitware.com, mas não é possível garantir compatibilidade com o VisWeb. Os arquivos dll estão compactados, e devem ser descompactados antes da sua instalação. O tamanho dos arquivos compactados é $1.99 \mathrm{MB}$ e $445 \mathrm{~KB}$, respectivamente.

Também é necessário ter o pacote "vtk.jar" (versão 2.4 do VTK), que contém as classes do VTK implementadas em Java. Esse arquivo pode ser instalado em qualquer diretório na máquina do cliente, devendo ser referenciado na variável de ambiente CLASSPATH, o que é feito inserindo uma linha de comando no arquivo "autoexec.bat", no caso para o ambiente Windows, conforme mostra a Listagem 6.1. O tamanho desse arquivo, também compactado, é $369 \mathrm{~KB}$.

"SET CLASSPATH=C:WOME_DIRETORIOWTKSIJAR;.

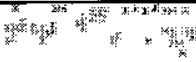

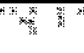

Listagem 6.1 - Exemplo de configuração da variável de ambiente CLASSPATH 
$\mathrm{O}$ arquivo de políticas “.java.policy”, no qual estão especificadas as permissões para que os módulos acessem os recursos necessários, também deve estar presente. Esse arquivo deve ser instalado no diretório "user.home" que, no ambiente Windows 95'98, pode ser o diretório "c:lwindows", no Windows NT, o diretório "c:lwinntlprofilesWNOME_USUARIO" e nos ambientes Unix/Linux, o diretório “\$HOME". Finalmente, deve-se ter o keystore “.keystore", referenciado no arquivo de políticas e associado a um alias, o qual também está especificado no arquivo de políticas. Isso garante a autenticação da assinatura quando um dos módulos for executado, pois o keystore têm a chave pública correspondente à chave privada utilizada para gerar a assinatura. $\mathrm{O}$ keystore também deve ser instalado no diretório "user.home". O tamanho desses dois arquivos não chega a $2 \mathrm{~KB}$.

Esses downloads, que devem ser feitos pelo cliente, podem ser um pouco demorados, pois dependem da taxa de transmissão da rede. Entretanto, isso é feito somente uma vez.

\subsection{Organização do código do VisWeb}

Cada módulo do VisWeb é uma applet Java executada a partir de uma página e, portanto, possui regras especiais que definem o seu comportamento. Essas applets são subclasses da classe JApplet, que faz parte do pacote "javax.swing", da qual herdam todo o comportamento e os atributos que permitem a sua execução como parte de uma página. A cláusula extends permite declarar que uma classe é subclasse de outra. A Listagem 6.2 mostra o código-fonte de uma applet Java que ilustra o procedimento de definição de um objeto pertencente a um dos módulos do VisWeb. Nesse exemplo é definida uma classe denominada "Demo", que é uma subclasse da classe JApplet. A classe é definida como pública (cláusula public), de forma que pode ser acessada por outras classes. A cláusula implements permite definir uma interface para tratar os eventos. Essa interface é um receptor de evento, que trata de um tipo específico de evento que, nesse caso, é o ActionListener, que trata de eventos ação, como o clique do mouse em um botão.

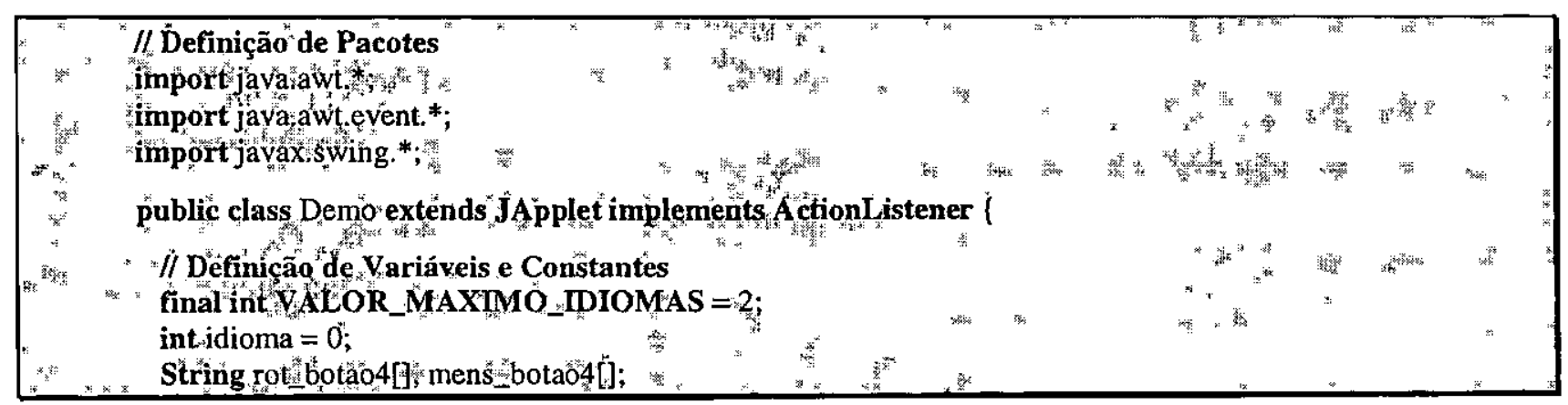




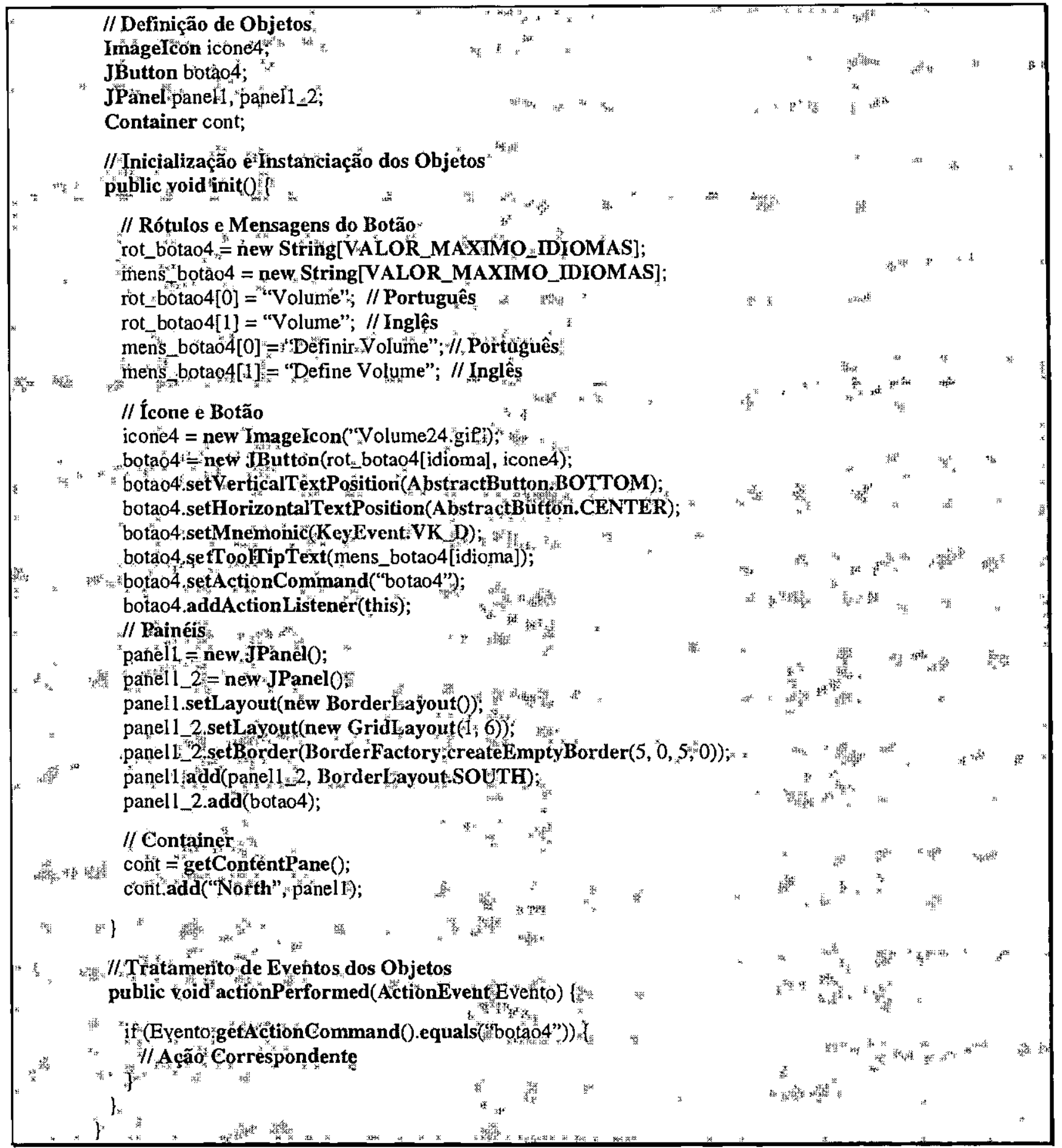

Listagem 6.2 - Exemplo de uma applet Java

Esse exemplo é útil para ilustrar como os módulos foram implementados. Inicialmente, são definidos todos os pacotes necessários, por meio da cláusula import. Em seguida, são definidos todas as variáveis, constantes e objetos utilizados. A ordem de definição dos objetos é de acordo com a sua disposição na janela, sendo que os nomes dados aos objetos também seguem essa ordem. A organização do código é ilustrada usando o módulo de rendering volumétrico direto. A Figura 
6.25 indica a organização hierárquica dos objetos que compõem a interface interna desse módulo (ver Figura 6.17).

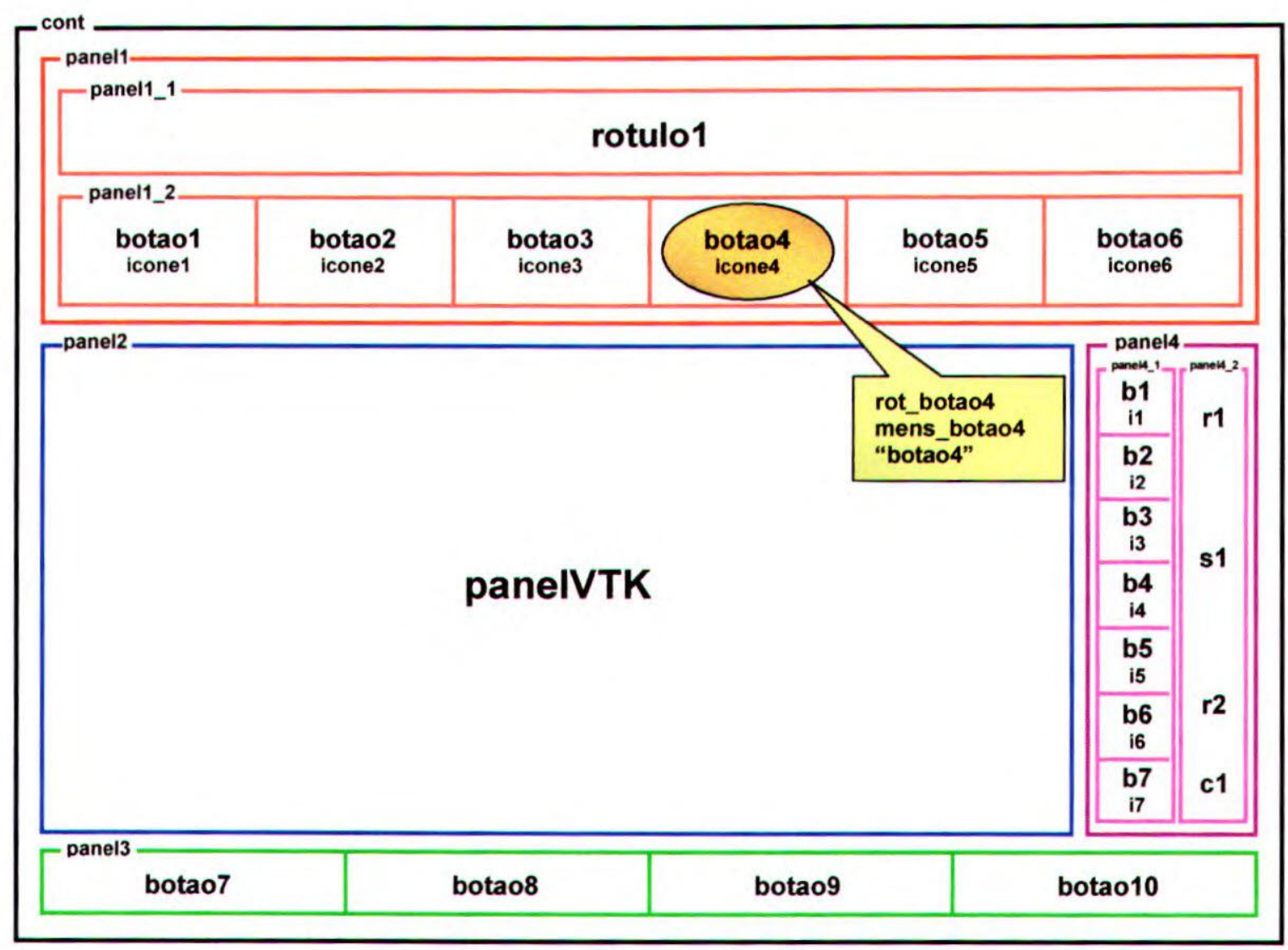

Figura 6.25 - Interface interna da janela principal da applet de rendering volumétrico direto

Após definir todos os objetos, eles são inicializados e instanciados no método init $($ ). Esse exemplo mostra a definição do objeto "botao4", que tem um objeto "icone4" associado, os quais estão destacados na Figura 6.25. Basicamente, a cada objeto estão associadas uma string como rótulo (em português e inglês), uma string para a descrição (mensagem que aparece quando o usuário passa o mouse sobre o objeto, em português e inglês) e um rótulo para o tratamento da ação do objeto, também destacados na Figura 6.25. Todos os objetos são associados a um objeto criado a partir da classe JPanel, que possui o seu próprio layout definido pelo método setLayout(). Os objetos criados a partir da classe JPanel são chamados de painéis, que são containers menores utilizados para agrupar objetos, podendo inclusive, agrupar outros painéis, como nesse exemplo. Isso é útil para conseguir uma melhor disposição dos objetos e, no final, esses painéis são associados a um objeto criado a partir da classe Container, que é um container maior. As classes JApplet e JPanel são subclasses da classe Container, da qual herdam o comportamento associado 
ao gerenciamento de layout. Finalmente, é feito o tratamento de eventos para todos os objetos aos quais foi associado um receptor de evento.

A Figura 6.26 ilustra a interface interna da janela de definição de um volume (ver Figura 6.18), que é apresentada quando o botão destacado na Figura 6.25 é acionado. O primeiro botão dessa janela recebe o nome de "b4Botao1", sendo que "b4" refere-se ao objeto "botao4", que é o objeto responsável por acionar essa janela. Todos os objetos no código-fonte de cada módulo são nomeados segundo este mesmo procedimento.

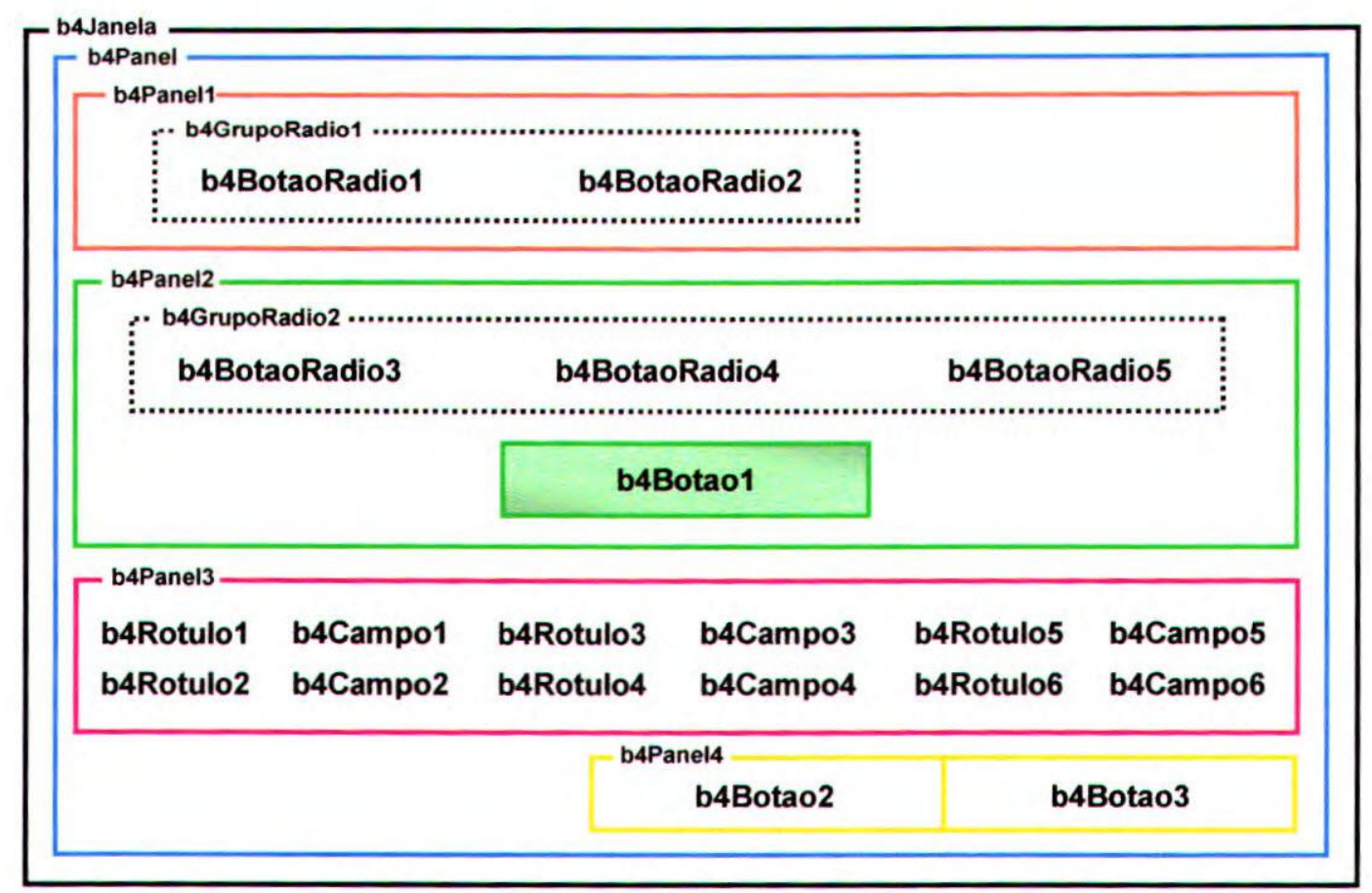

Figura 6.26 - Interface interna da janela de definição de volume

Para finalizar, é ilustrada na Figura 6.27 a interface da janela de definição de intervalos de opacidade utilizando uma tabela default, apresentada quando o botão em destaque na Figura 6.26 é acionado. Essa figura ilustra a disposição dos objetos e a definição dos seus nomes. 


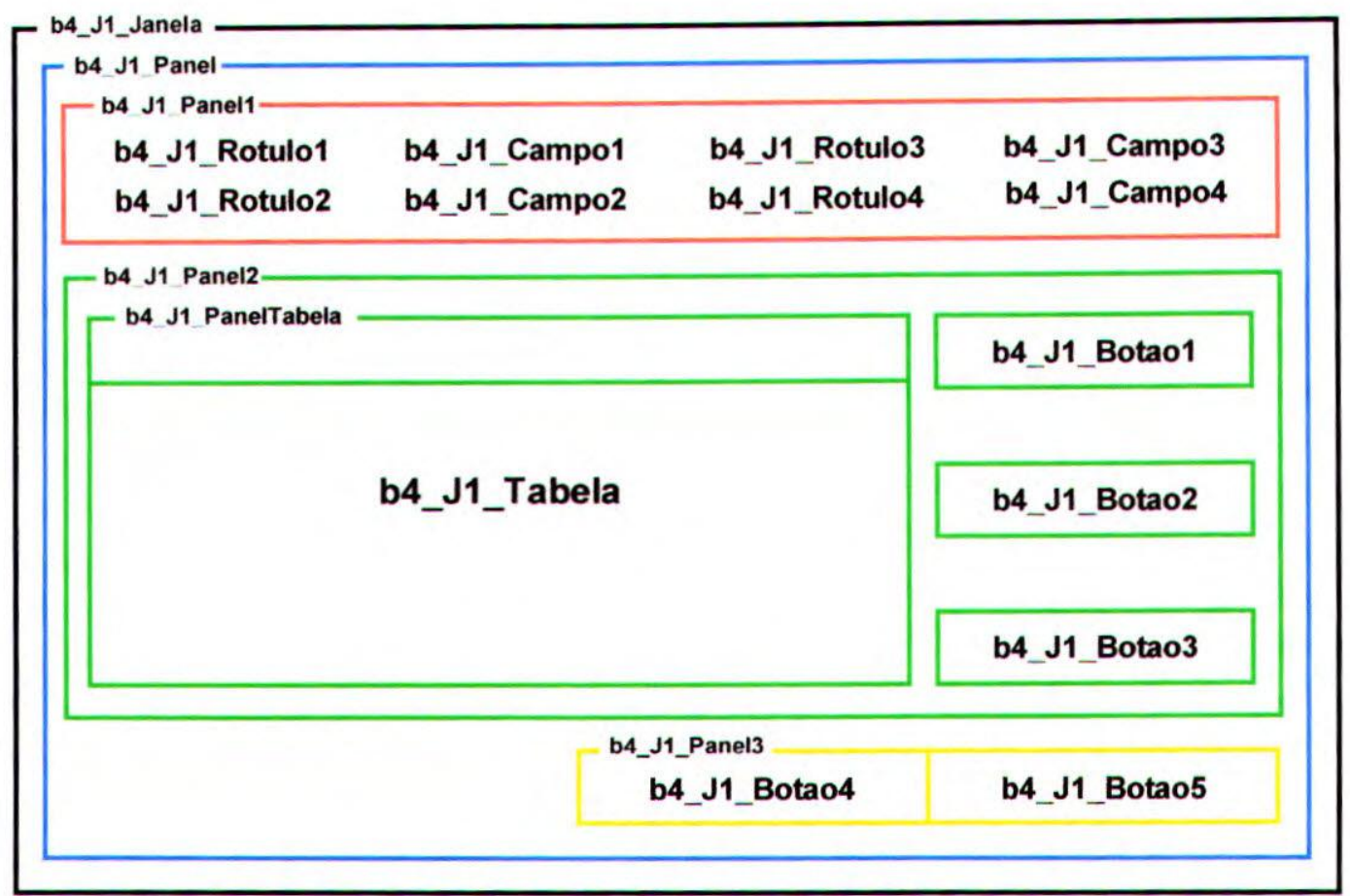

Figura 6.27 - Interface interna da janela de definição de intervalos utilizando uma tabela default

\subsection{Considerações finais}

Este Capítulo teve como objetivo apresentar a funcionalidade completa do VisWeb. Também foi discutida a estrutura interna de um módulo do VisWeb, sendo que os demais módulos adotam a mesma estrutura geral. O VisWeb é um sistema flexível e de fácil expansão, sendo que funções adicionais podem ser incorporadas de uma maneira bem simples. A interação no VisWeb é rápida,

pois é feita localmente e depende apenas da máquina do cliente. É oferecido ao cliente um conjunto de opções que permitem alterar os parâmetros da visualização de forma interativa. No próximo Capítulo são apresentadas outras ferramentas de visualização de dados na Web. 
visualização volumétrica distribuída para hardware de propósito geral, e a integraram ao browser Mosaic como um serviço de visualização. A ferramenta, denominada VIS, utiliza um pool de estações gráficas para gerar modelos $3 \mathrm{D}$ de conjuntos de dados volumétricos, distribuindo a tarefa entre as estações disponíveis. Para possibilitar a distribuição da informação gerada para clientes remotos, os autores estenderam o ambiente Mosaic para suportar dados volumétricos, e definiram um protocolo de comunicação para a troca de informações entre o VIS e o Mosaic para permitir a execução de tarefas de visualização volumétrica. Dessa forma, é possível a inclusão de visualização volumétrica interativa em documentos HTML. A partir do browser, clientes remotos podem solicitar a execução de tarefas de visualização que são repassadas ao ambiente VIS, e o resultado é retomado no próprio documento HTML.

Um outro exemplo foi desenvolvido por Liu et al. [Liu96], que implementaram um sistema de visualização distribuído e interativo, chamado Discover (Distributed Interactive Scientific Computing and Visualization Environment). Esse sistema adota uma arquitetura cliente/servidor, sendo composto por um host virtual, que inclui um ou mais PC's, e um pool de processadores que fomecem o poder computacional para o host virtual. O sistema oferece funções tanto para os clientes quanto para os servidores, sendo que os serviços no cliente incluem apenas operações simples de manipulação. Atualmente, o ambiente é voltado para aplicações clínicas, mas o arcabouço adotado para a sua implementação é, em princípio, adequado para outras áreas. $\mathrm{O}$ ambiente suporta visualizações cooperativas, e usuários posicionados em diferentes clientes podem compartilhar uma mesma janela de visualização.

Ferramentas distribuídas também são discutidas em outros trabalhos [Bro00c, Coy99]. Nas Seções seguintes são apresentadas algumas ferramentas que incorporam recursos de visualização na $W e b$.

\subsection{Ferramentas de visualização no cliente}

A visualização no lado do cliente significa que todos os passos da visualização são executados no cliente. Atualmente, há duas maneiras de fazer isso. A primeira é disponibilizar o software de visualização para o cliente ou, altemativamente, pode-se usar applets Java [Bro00c, Coy99]. Essas alternativas serão discutidas nas Subseções seguintes, destacando algumas das ferramentas existentes que adotam uma dessas abordagens. 


\subsubsection{Software pré-instalado}

As ferramentas apresentadas nesta Subseção se enquadram no Cenário 3 (ver Figura 4.4), em que todo o processo de visualização é executado no cliente. Nessa abordagem assume-se que o software de visualização está instalado no cliente. A idéia básica é a seguinte: o usuário pode selecionar um arquivo de dados para ser visualizado, sendo que isso pode ser feito, por exemplo, a partir de uma página $W e b$. O arquivo de dados é recuperado usando um tipo MIME, que invoca o software de visualização pré-instalado no cliente como uma aplicação auxiliar ou como um plug-in do browser [Bro00c, Coy99].

Essa foi a abordagem original da ferramenta VIS, descrita na Seção 7.2, que recuperava os dados no formato HDF, identificado como um tipo MIME hdf/volume. Essa abordagem também foi adotada por Hibbard [Hib00], que implementou um software de visualização chamado Vis5D. Dados meteorológicos são descarregados por meio de um browser Web como um tipo MIME application/vis5d e, então, o Vis5D é invocado para a visualização de previsão do tempo [Bro00c, Coy99]. O tamanho desse software, que inclui também algumas dll's e exemplos de arquivos de dados, é de 4.97 MB. A Figura 7.1 ilustra a janela principal dessa ferramenta.

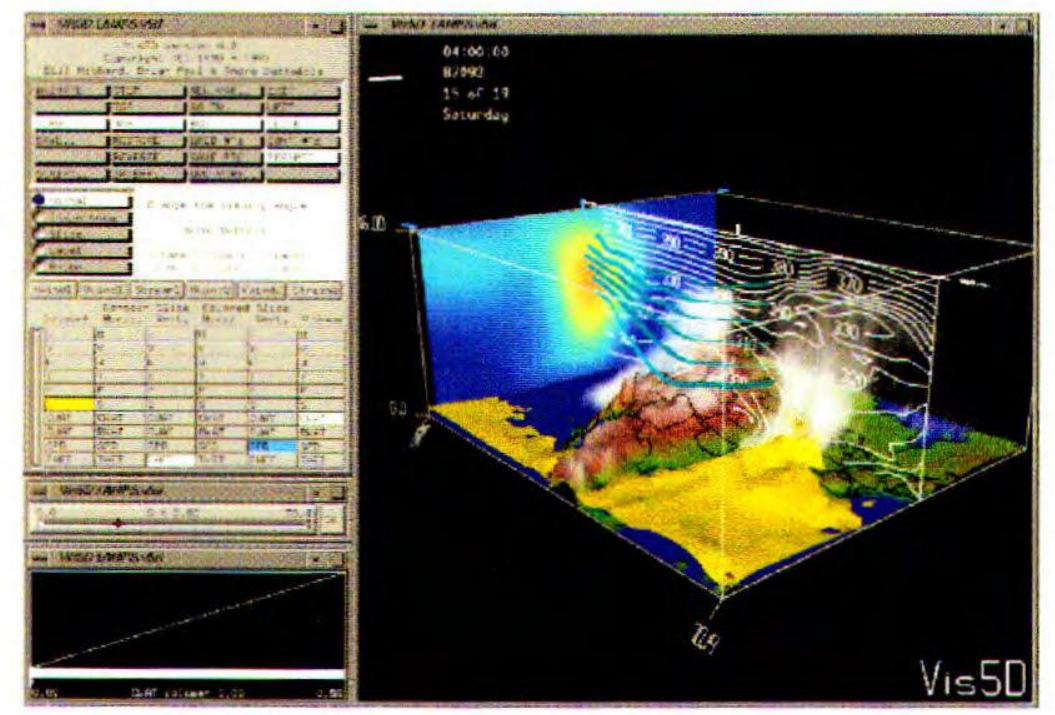

Figura 7.1 - Janela principal da ferramenta Vis5D [Hib00]

Um outro exemplo é o VisAD [Hib97, Hib98], também desenvolvido por Hibbard, cuja janela principal é ilustrada na Figura 7.2. O VisAD é uma aplicação Java para visualização interativa e colaborativa e análise de dados numéricos. Essa aplicação, que faz uso da API de Java 3D e Java RMI, deve ser descarregada no cliente, que precisa ter o JDK instalado e as APIs necessárias. Dessa 
forma, o VisAD é executado na máquina do cliente, usando arquivos de dados locais. $\mathrm{O}$ tamanho dessa aplicação, que é um arquivo JAR, é de $2.07 \mathrm{MB}$.

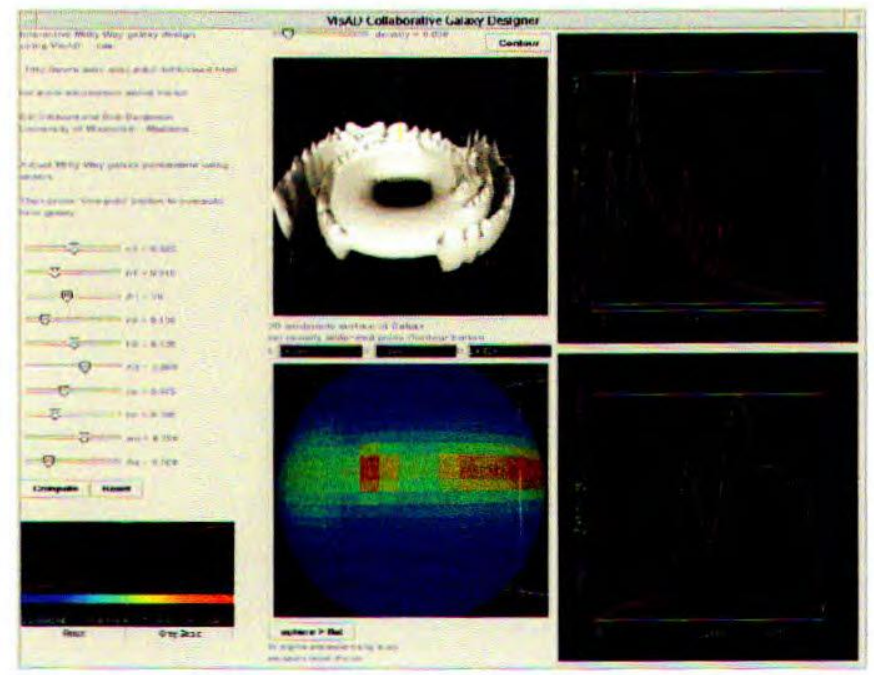

Figura 7.2 - Janela principal da ferramenta VisAD [Hib98]

Brodlie et al. [Bro00c] e Coyle [Coy99] descrevem outras ferramentas que se enquadram nessa abordagem. As ferramentas apresentadas nesta Seção apresentam as vantagens e limitações típicas do Cenário 3, discutido na Seção 4.3.3.

\subsubsection{Applets Java}

Essa abordagem na qual se enquadra o VisWeb, pode ser descrita como um meio termo entre os Cenários 3 e 4, pois todo o pipeline é executado no cliente, embora o conjunto de funcionalidades disponíveis esteja definido no servidor que disponibiliza as applets.

Michaels e Bailey [Mic97] descrevem uma ferramenta para visualização científica implementada como uma applet Java que usa somente a API AWT [Gos96] para a construção de gráficos 3D. Essa ferramenta, denominada VisWiz, foi desenvolvida com os objetivos de ser completamente independente de plataforma, ser fácil de usar, oferecer um conjunto básico de funcionalidades de visualização $3 \mathrm{D}$ para os usuários analisarem os seus próprios conjuntos de dados, e fornecer uma boa interatividade. Os usuários têm que fazer upload dos seus conjuntos de dados para o servidor e, em seguida, podem aplicar técnicas básicas de visualização volumétrica, tais como extração de superfícies, planos de corte, nuvens de pontos (point clouds), e mapas de elevação. Eles podem, também, interagir com os modelos de visualização resultantes a taxas razoáveis. Isso é possível devido a uma implementação cuidadosa, a simplificações introduzidas em alguns algoritmos de visualização, e a um conjunto limitado de opções de rendering. Por exemplo, somente tonalização 
flat é utilizada no modelo de iluminação. A janela principal dessa ferramenta é ilustrada na Figura 7.3 .

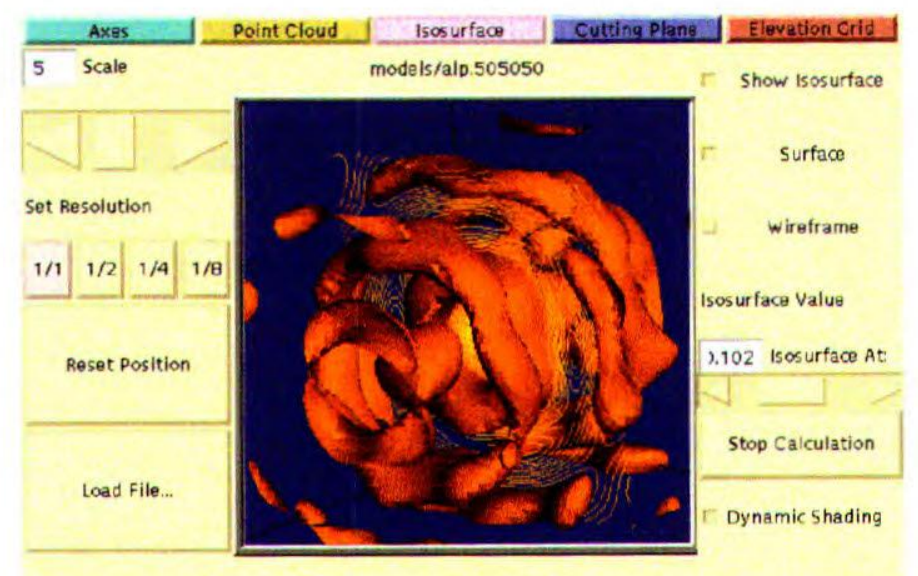

Figura 7.3 - Janela principal da ferramenta VisWiz [Mic97]

Acessar o sistema de arquivos do cliente era impossível há alguns anos atrás, e Michaels e Bailey, na sua implementação do VizWiz, contornaram o problema fazendo com que os clientes carregassem os seus arquivos de dados no servidor para acesso pela applet de visualização. Entretanto, essa não é uma solução viável em um contexto real de produção, pois coloca uma carga enorme no servidor. Além disso, usuários em potencial irão, freqüentemente, se deparar com problemas de transmissão da rede e com atrasos inaceitáveis. Adicionalmente, o VizWiz tem um conjunto de técnicas de visualização muito restrito, uma vez que todas as técnicas disponibilizadas tiveram que ser totalmente implementadas usando a API AWT, cujos recursos gráficos são limitados. Além disso, essa API não permite disponibilizar recursos avançados de interface com o usuário, pois é limitada a poucos widgets. No VisWeb, nenhum desses problemas ocorre, pois é permitido acessar o sistema de arquivos do cliente, é fornecido um conjunto de técnicas mais amplo e não é usada a API AWT, e sim a sua extensão, o Java Swing, que fornece recursos avançados de interface com o usuário.

Brodlie e Wood [Bro00c] mencionam que uma das maiores dificuldades encontradas no uso de applets Java para visualização é a questão das restrições de segurança, que não permitem, por exemplo, ler um arquivo de dados na máquina do cliente. Mencionam ainda que existem soluções, porém elas são caras. Isso já não é mais verdade, pois o mecanismo de segurança de Java 1.2 permite resolver esse problema sem nenhum custo, como foi feito no VisWeb. Eles sugerem duas alternativas: a primeira é a que foi usada pelo VisWiz, ou seja, fazer upload do arquivo de dados 
para o servidor. A outra é uma abordagem mais genérica, em que os dados podem estar em qualquer lugar e o acesso é feito por meio de uma URL.

Um outro exemplo de ferramenta de visualização que é executada no cliente é descrito por Chang, Coddington e Hutchenso [Cha98]. Eles descrevem o projeto e a implementação de um viewer para os dados (imagens digitalizadas) do Visible Human baseado na Web, implementado como uma applet Java que oferece uma interface para o usuário selecionar o tipo de dado e o corte desejado. A Figura 7.4 ilustra a página principal dessa ferramenta.

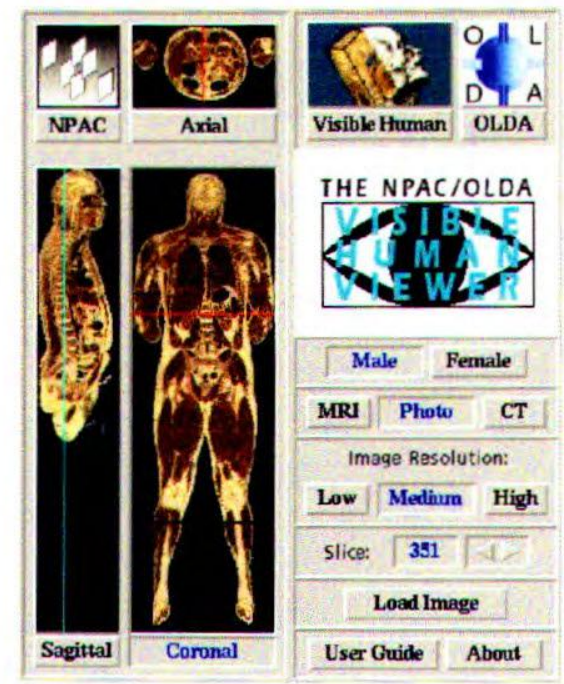

Figura 7.4 - Janela principal da applet Visible Human Viewer [Cha98]

Essa alternativa adota a solução de disponibilizar as imagens por meio de uma URL, também para contornar as restrições associadas a applets Java. Uma das vantagens de disponibilizar as imagens por meio de uma URL é que o usuário pode salvar a imagem na sua máquina.

\subsection{Ferramentas de visualização no servidor}

Nessa abordagem, a visualização é gerada no servidor e o resultado é disponibilizado para os clientes. Por meio de uma interface com o usuário baseada na $W e b$, que pode ser um formulário HTML ou uma applet Java, o usuário seleciona o arquivo de dados a ser visualizado, e alguns parâmetros que indicam como a visualização deve ser gerada. Esses dados são passados ao servidor, que executa um software para criar a visualização requerida. O resultado é transmitido de volta para o cliente, como um documento VRML ou como uma imagem [Bro00c, Coy99], dependendo do modelo da visualização (3D ou 2D). Se retornar um documento VRML, esse tipo de solução se enquadra no Cenário 4 (ver Figura 4.5), em que só o rendering é feito no cliente e, se retornar um 
uma imagem, tudo foi feito no servidor, e aí é o Cenário 1 (ver Figura 4.2). Nas Subseções seguintes são apresentadas algumas ferramentas que se encaixam nessa categoria.

\subsubsection{Retornando VRML}

Esse tipo de visualização no servidor é possível pelo fato de VRML ser um padrão ISO para distribuição de ambientes 3D sobre a $W e b$, sendo que existem atualmente vários plug-ins disponíveis para a maioria das plataformas.

Um exemplo que se encaixa nessa abordagem é descrito por Wood, Brodlie e Wright [Woo96 ], que descrevem um sistema para monitorar informações sobre a qualidade do ar. Por meio de um formulário HTML, ilustrado na Figura 7.5, o usuário seleciona os dados (localização, período de tempo e poluente) e o estilo de plot (diagrama de blocos ou superfície). Um CGI gera visualização e o resultado é retornado ao usuário como um documento VRML.

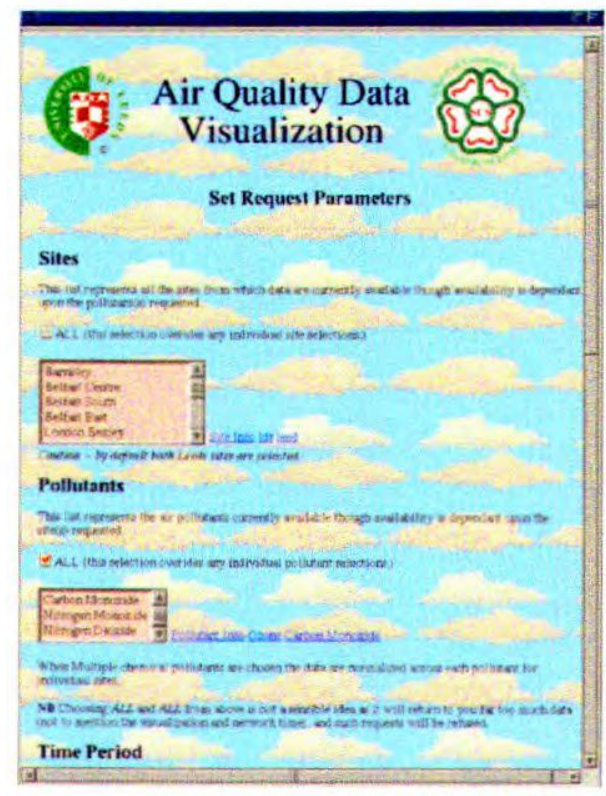

Figura 7.5 - Página principal do Serviço de Visualização da Qualidade do Ar [Woo96]

Embora a abordagem implementada use extração de superfícies, ela é genérica e pode ser aplicada a qualquer tipo de visualização [Bro00c]. A página do VTK (http://www.kitware.com/vtk.html) inclui um exemplo de um servidor de visualização, já apresentado no Capítulo 4, com objetivo de ilustrar aos usuários do VTK como construir o seu próprio servidor. A Figura 7.6 ilustra uma página deste servidor, que fornece um formulário HTML para o usuário selecionar os parâmetros da visualização. 


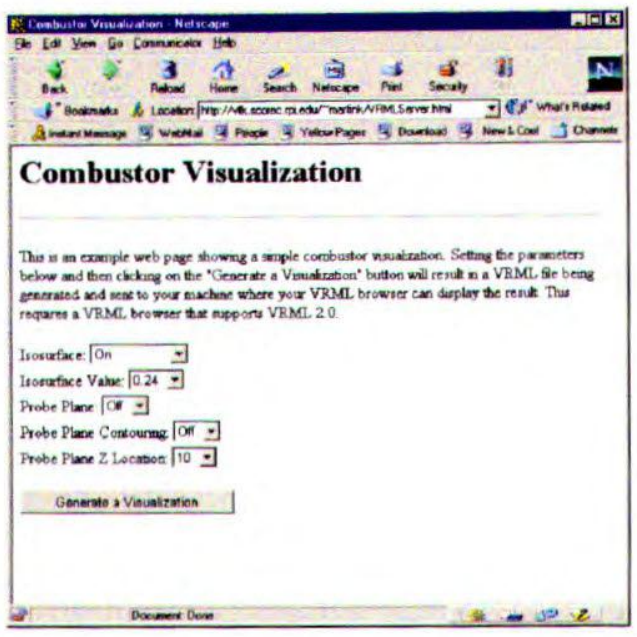

Figura 7.6 - Página do VTK para definição de parâmetros de uma visualização

O resultado é retornado em um documento VRML que exibe o modelo de visualização gerado segundo os parâmetros definidos pelo usuário, comon ilustra a Figura 7.7.

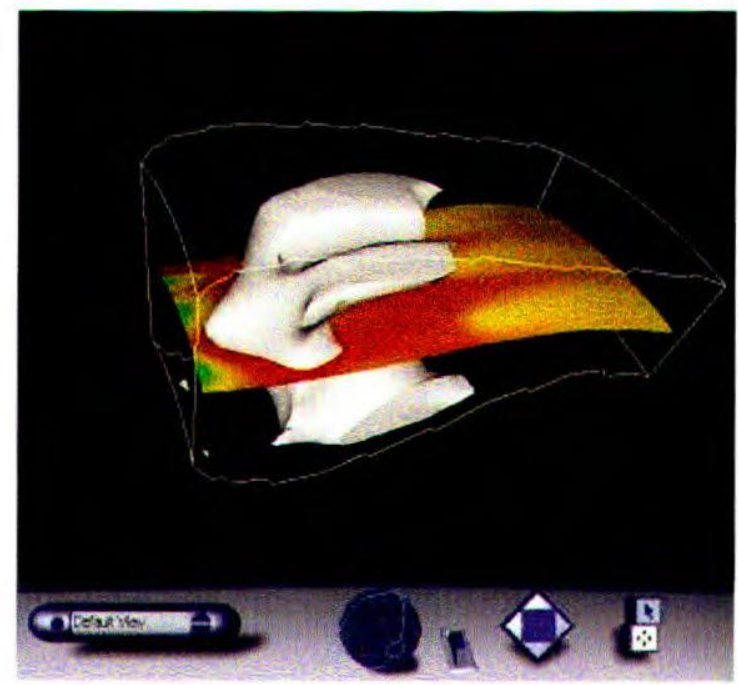

Figura 7.7 - Exemplo de uma visualização com VRML

Uma outra forma de oferecer uma interface com o usuário é por meio de applets Java, ao invés de formulários HTML, o que garante uma maior flexibilidade e uma interface visualmente mais atrativa. Um exemplo interessante que usa essa abordagem foi desenvolvido por Engel, Grosso e Ertl [Eng98]. Eles implementaram um algoritmo progressivo de extração de superfícies proposto por Ertl como uma aplicação baseada no paradigma cliente/servidor. O servidor gera isosuperfícies de múltipla resolução a partir de um conjunto de dados volumétricos, e as envia progressivamente ao cliente, o qual está acessando uma applet Java por meio de um browser. Por meio da EAI, essa applet é capaz de acessar o plug-in VRML, que é usado para criar a geometria dinamicamente. A Figura 7.8 ilustra a página principal dessa ferramenta, denominada Prolet. 


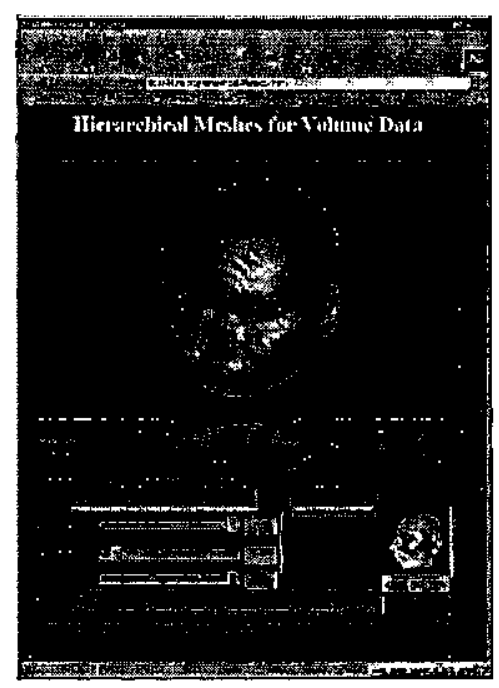

Figura 7.8 - Página principal da ferramenta Prolet

O usuário pode definir os parâmetros por meio de uma interface em Java, ilustrada na Figura 7.9.

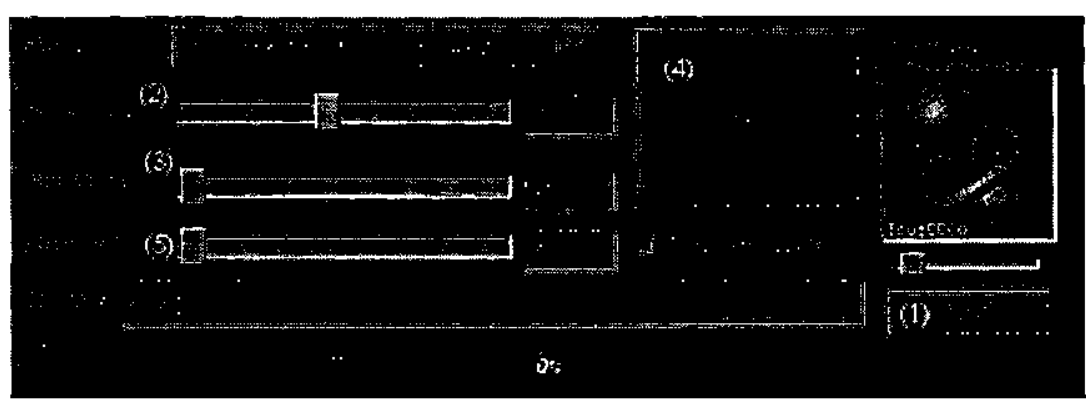

Figura 7.9 - Interface com o usuário da ferramenta Prolet [Eng98]

Outras ferramentas que adotam abordagem semelhante são discutidas em diversos trabalhos [Bro00b, Bro00c, Coy99, Eng99, Kha97, Kha98, Li00]

\subsubsection{Retornando imagem}

Como uma alternativa para VRML, é possível gerar a projeção de modelos 3D em um plano de imagem no servidor, e transferir a imagem resultante para o browser [Bro00c, Coy99]. Essa abordagem pode ser útil para clientes que têm capacidade limitada de rendering 3D, ou que não têm o plug-in VRML.

Uma ferramenta que usa essa abordagem, denominada CurVis, foi desenvolvida por Thiesel [Thi99], e permite exibir visualizações de fluxos de fluidos 2D. Um formulário HTML permite ao usuário definir vários parâmetros, como ilustrado na Figura 7.10. 


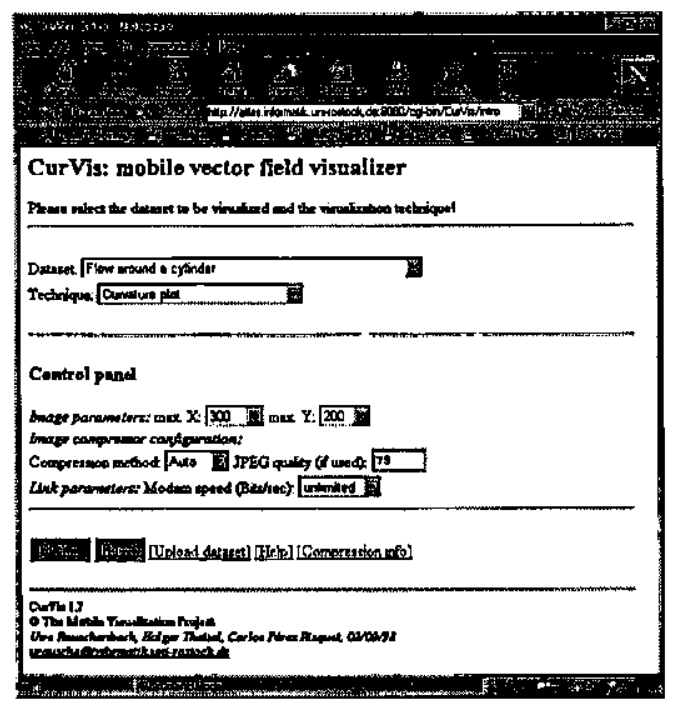

Figura 7.10 - Página principal da ferramenta CurVis

Esses parâmetros são passados ao servidor, que executa um CGI, retornando uma imagem em uma página Web, ilustrada na Figura 7.11.

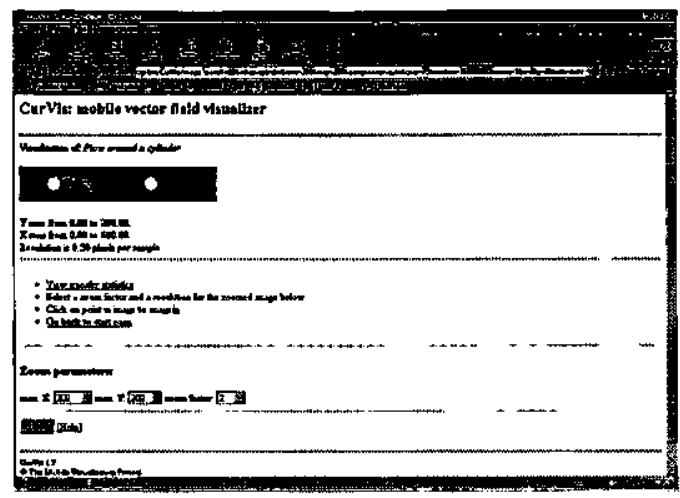

Figura 7.11 - Página da ferramenta CurVis que exibe a visualização definida na Figura 7.10

\subsection{Considerações finais}

Neste Capítulo foram apresentadas várias ferramentas, classificadas segundo o local em que são geradas as visualizações: no cliente ou no servidor. Cada abordagem possui vantagens e limitaçōes, sendo que algumas são feitas em Brodlie e Wood [Bro00c]. Para aplicações interativas, um aspecto atraente das abordagens que geram a visualização no cliente é o forte acoplamento entre a interface com o usuário, os dados e o software de visualização. Nesse contexto, applets Java são soluções atrativas se o processamento é simples e os arquivos de dados são pequenos. A outra solução (software pré-instalado no cliente) é mais atrativa quando os conjuntos de dados são grandes, pois a necessidade de transferir os dados para o servidor se torna um fator crítico. Por outro lado, as abordagens no lado do servidor têm como vantagem o fato de todo o processamento pesado ser feito 
no servidor que, assume-se, será mais rápido do que a máquina do cliente. Essa é a motivação clara na solução que usa extração progressiva de isosuperfícies. Uma outra vantagem dessa abordagem é que ela permite que interfaces com o usuário simples, feitas sob medida, sejam usadas como frontends por sistemas de visualização mais complexos, como no serviço de qualidade do ar. A escolha entre VRML ou imagens 2D depende, tipicamente, da natureza dos dados. O VisWeb pode, por um lado, ser considerado como uma interface gráfica que é um front-end para um subconjunto do VTK. Na nossa visão, o sistema se enquadra como um meio termo entre visualização no lado do cliente e no lado do servidor. Todos os pipelines de visualização estão definidos no servidor, e por meio das applets, todo o processo de visualização é executado no cliente. No próximo Capítulo são apresentadas as conclusões deste trabalho e sugestões de trabalhos futuros. 


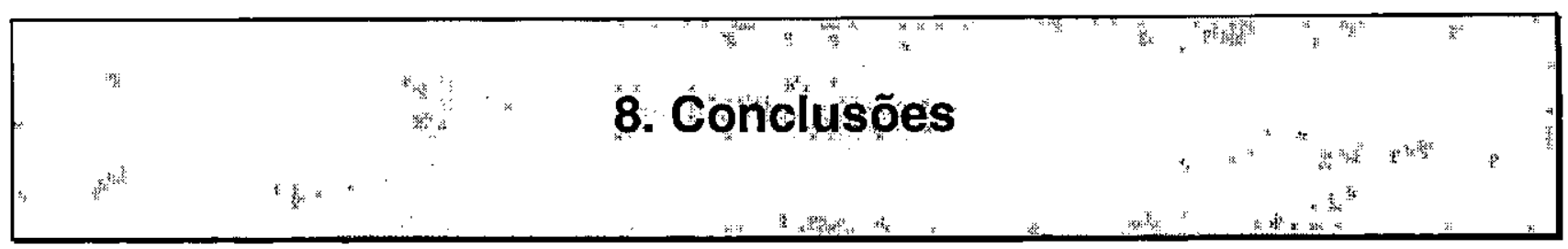

\subsection{Considerações iniciais}

A disponibilização de recursos de visualização na Web abre um número de possibilidades para cooperação, ensino e treinamento, pela garantia de acessibilidade de alcance mundial a um custo muito baixo. Uma solução baseada em applets Java pode reduzir consideravelmente o esforço de manutenção requerido por desenvolvedores de softwares de visualização, uma vez que não existem executáveis a serem distribuídos. A principal contribuição deste trabalho foi o desenvolvimento do ambiente VisWeb, indicando claramente que as tecnologias disponíveis atualmente podem ser exploradas para criar ambientes de visualização interativos sofisticados para serem acessados na Web. Tais ambientes podem ir muito além da manipulação de mundos VRML, nos quais o realismo é muito sacrificado.

Foi submetido um artigo [Alv00] ao SIBGRAPI'2000 referente a este trabalho. Espera-se, com ele, contribuir para a discussão sobre visualização na Web, principalmente porque a solução adotada na implementação do VisWeb parece não ter sido adotada por nenhuma outra ferramenta de visualização de dados na Web. Nenhum dos trabalhos discutidos no Capítulo 7 exploram a política de segurança de Java para interfacear com código nativo e acessar o sistema de arquivos do cliente, garantindo um ambiente genérico. Neste Capítulo, na Seção 8.2 são comentadas as vantagens e limitações do VisWeb, e na Seção 8.3 são apresentadas sugestões para trabalhos futuros.

\subsection{VisWeb: vantagens e limitações}

O VisWeb oferece recursos de visualização embutidos em applets Java que acessam o VTK, solução que apresenta tanto vantagens quanto limitações. Uma vantagem óbvia é que a estrutura de visualização fornecida pelo VTK fica disponível diretamente. O VisWeb pode ser facilmente estendido para incorporar técnicas de visualização adicionais suportadas pelo VTK, desde que uma interface adequada para a definição de parârnetros seja fornecida. Alternativamente, a mesma estrutura pode ser empregada para fornecer soluções voltadas para domínios de aplicação específicos. 
A interação no VisWeb é rápida, pois é feita localmente no cliente. O usuário tem um conjunto de opções que permite alterar os parâmetros da visualização de forma simples e interativa. Essas opçōes foram implementadas usando o Java Swing, uma extensão da API AWT que oferece recursos avançados de interface com o usuário. O Swing é inteiramente implementado em Java, ao contrário da AWT, que possui alguns problemas de portabilidade e não oferece um conjunto tão "rico" de recursos.

O VisWeb estimula uma maior interação com usuários de visualização, pois é possível a qualquer usuário, em qualquer lugar, gerar visualizações de diferentes conjuntos de dados. Nesse contexto, a idéia inicial deste trabalho era disponibilizar um servidor para os pesquisadores do Grupo de Visão Cibernética do IFSC, que já vem interagindo com o Grupo de CG \& PI. Entretanto, a estrutura genérica do VisWeb o torna uma ferramenta de divulgação da ViSC para uma classe mais ampla de usuários em potencial.

Este foi o primeiro trabalho sobre visualização na Web realizado no âmbito do grupo de CG \& PI e, por essa razão, algumas considerações são apropriadas. No início do desenvolvimento do VisWeb, praticamente não se encontrava trabalhos relacionados descritos na literatura. Hoje em dia, como pôde-se notar no Capítulo 7, já existem várias ferramentas para visualização de dados na Web. Uma das maiores dificuldades encontradas foi como garantir às applets o acesso a recursos locais, pois não havia muita informação a respeito. Esse acesso era necessário porque o VTK é um código nativo e, a princípio, as applets não podem fazer esse tipo de acesso. Também era necessário garantir acesso aos conjuntos de dados alocados na máquina do cliente. Por essas razões, foi feito um estudo sobre mecanismos de segurança em Java, o que permitiu escolher o mecanismo que melhor se adapta às nossas circunstâncias. Foi, então, escolhido e estudado detalhadamente o mecanismo de segurança de Java (versão 1.2), devido à sua flexibilidade. Esse mecanismo permite resolver o problema de forma que garante ao usuário maior comodidade. Acreditamos que, do ponto de vista do grupo, este trabalho proporcionou um avanço importante na compreensão de como recursos de visualização podem ser disponibilizados na $W e b$, pois foram estudadas várias abordagens diferentes. Existem trabalhos relacionados em desenvolvimento no grupo, na área de visualização distribuída, que certamente usarão este trabalho como ponto de partida.

Nenhuma das ferramentas apresentadas no Capítulo 7 adota a solução usada no VisWeb. Algumas das descrições citam, inclusive, problemas que no VisWeb foram resolvidos. O principal, sem dúvida, é o fato de applets Java, a princípio, não acessarem recursos locais do cliente, o que impede, por exemplo, a leitura de um arquivo de dados. Dessa forma, uma das soluções descritas na 
literatura consiste em fazer um upload dos arquivos de dados para o servidor em que a applet está armazenada. Assim, quando a applet for acessada, pode-se descarregar o arquivo de dados. Nessa solução o usuário tem que, primeiro, esperar o arquivo de dados ser carregado para o servidor e, depois, esperar novamente que este seja descarregado pela applet. O VisWeb resolve isso com o uso de applets assinadas.

Um outro problema de applets Java é o desempenho. Isso pelo fato do compilador Java traduzir o código-fonte em bytecodes interpretados pela JVM do browser ou do Java Plug-in. Com o VisWeb, esse problema é minimizado, pois toda a visualização é feita pelo VTK, em código C++, de forma, que as operações de visualização são executadas com um bom desempenho. Entretanto, o usuário deve ter as bibliotecas do VTK instaladas localmente. Uma possível alternativa seria construir todas as técnicas de visualização em Java, enquanto a linguagem não disponibiliza uma API de visualização, mas isso sacrificaria o desempenho. Entretanto, recentemente, a Sun lançou a versão 1.3 de Java, afirmando que a grande diferença em relação às versões anteriores é o melhor desempenho.

Outra limitação do VisWeb é o fato de applets criadas com a versão 1.2 de Java ainda não serem suportadas pelos browsers, forçando o cliente a ter instalado na sua máquina o Java Plug-in. Essa limitação, a princípio, não será resolvida rapidamente, pois os browsers estão demorando cada vez mais para incluir os recursos das novas versões de Java, e alguns recursos são disponibilizados de forma diferenciada. Por exemplo, tanto a Netscape quanto a Microsoft adotam mecanismos de segurança para applets diferentes dos que são oferecidos em Java.

\subsection{Sugestões para trabalhos futuros}

O ambiente pode ser estendido para suportar uma gama mais ampla de técnicas de visualização genéricas. Por outro lado, pode-se adaptá-lo para domínios específicos, o que deve ser feito no contexto do projeto "Visualização no Suporte à Atividades Odontológicas" (Fapesp proc. 98/126448). O objetivo é criar uma versão do VisWeb que integre um conjunto de recursos para a manipulação de modelos dentários na Web.

Facilidades adicionais poderiam ser incorporadas no ambiente que vão além de apenas aumentar as funcionalidades de visualização. Por exemplo, os parâmetros de visualização definidos durante uma sessão do usuário poderiam ser salvos para serem posteriormente usados pelo mesmo usuário, ou por outros. No primeiro caso, tais informações poderiam ser salvas no cliente, evitando o tráfego da 
rede e, no segundo, poderiam ficar no servidor, sendo associadas ao arquivo de dados correspondente. Tal facilidade poderia servir de base para a cooperação entre usuários de visualização distribuída, e outras funcionalidades poderiam ser adicionadas com esse objetivo em mente. A habilidade de salvar os parâmetros de configuração usados em uma sessão de visualização poderia, também, fornecer um feedback precioso para projetistas de visualização sobre as dificuldades enfrentadas pelos usuários de visualização.

Uma outra melhoria no sistema seria permitir ao usuário uma configuração mais flexível do ambiente. No VisWeb, já é possível definir alguns parâmetros, tais com o idioma e a cor da área de visualização, na janela principal de cada módulo. O sistema poderia permitir a definição interativa de opçōes como o posicionamento da área de visualização, entre outras.

O VisWeb foi implementado usando a versão 1.2.2 de Java e a versão 2.4 do VTK. Entretanto, já existem a versão 1.3 de Java e a versão 3.1 do VTK. O sistema já foi testado com a versão 1.3 de Java e não foi necessário fazer nenhuma modificação. Ainda é necessário estudar as possíveis modificações da versão 3.1 do VTK para que o VisWeb venha a ser disponibilizado com as atuais versões de Java e do VTK.

Alguns testes de acesso ao VisWeb de diferentes localidades foram feitos em ambientes Windows $(95,98,2000$ e NT) e foram bem sucedidos. O VisWeb pode ser acessado tanto pelo browser Netscape Navigator quanto pelo Internet Explorer, nas versões 4.x ou superior. Pretende-se tornar o sistema disponível para acesso público na $W e b$ em breve.

O VisWeb também oferece um ponto de partida interessante para o estudo de visualização colaborativa, e o sistema pode ser estendido para fornecer um ambiente colaborativo no qual vários usuários compartilhassem a mesma visualização. Por meio de um mecanismo adequado tudo o que fosse feito, por exemplo, em uma applet, de acordo com as configurações definidas, seria passado ao servidor que, por sua vez, se encarregaria de repassar o resultado às outras applets. Isso seria interessante na área de educação a distância. Por exemplo, um professor localizado em qualquer lugar poderia apresentar a sua aula por meio de uma applet Java. Essa applet passaria todas as açōes do professor para o servidor, que as repassaria para as demais applets sendo acessadas pelos alunos, que poderiam acompanhar o que o professor está fazendo. Se o professor, por exemplo, interage com uma visualização, os alunos vêem essa mesma interação. O contrário também poderia ser feito, ou seja, o professor acompanha como os alunos estão executando uma determinada tarefa, permitindo assim identificar as dificuldades encontradas. Essas são apenas algumas das possíveis 
utilizações de visualização colaborativa, sendo que outras sugestões nessa linha podem ser encontradas em vários trabalhos na literatura [Bro96, Bro00a, Bro00c, Cha98, Eng99, Hib97, Hib98, Joh98, Woo95]. 


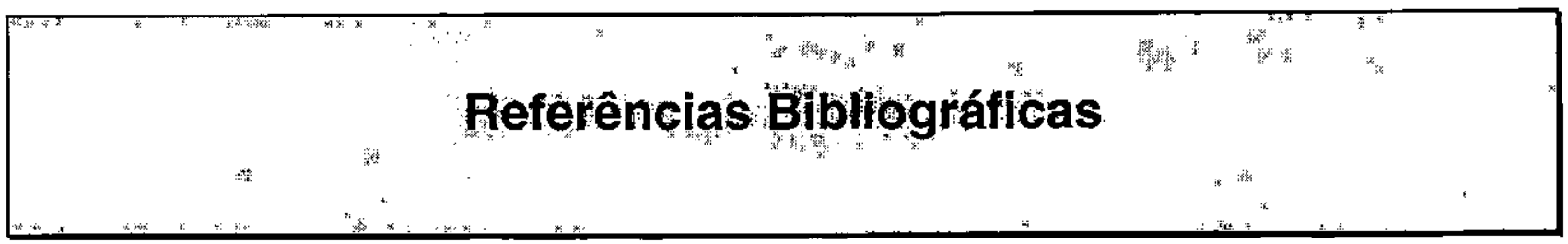

[Alv00] Alves, A.D.; Oliveira, M.C.F.; Minghim, R.; Nonato, L.G. - "Interactive Visualization over the WWW", artigo submetido ao SIBGRAPI'2000.

[Ame96] Ames, A.; Nadeau D.; Moreland, J. - The VRML Sourcebook, John Wiley \& Sons, 1996.

[And99] Andrews, M. - "Plugging into Swing". Disponível on-line em:

http://java.sun.com/products/jfc/tsc/web/java plug-in/java_plug-in.html. Visitado em 08 de setembro de 1999.

[Ang94] Ang, C. S.; Martin, D. C.; Doyle, M. D. - "Integrated Control of Distributed Volume Visualization Through The World Wide Web", Proceedings IEEE Visualization'94, pp. 13-20, 1994.

[Blo99] Block, C. - "Servlets". Disponível on-line em:

http:/liava.sun.com/docs/books/tutorial/servlets/index.html. Visitado em 03 de maio de 1999.

[Blu96] Blum, A. - Building Business Web Sites, MIS:Press, 1996.

[Bri99] Brigner, P. - "Creating Signed, Persistent Java Applets", Dr. Dobb's Journal, pp. 82-88, fevereiro, 1999.

[Bro92] Brodlie, K. W.; Carpenter, L. A.; Earnshaw, R. A.; Gallop, J. P.; Hubbold, R. J.; Mumford, A. M.; Osland, C. D.; Quarendon, P. - Scientific Visualization - Techniques and Application, SpringerVerlag, 1992.

[Bro96] Brodlie, K; Wood, J.; Wright, H. - "Scientific Visualization - Some Novel Approaches to Learnig, ACM SIGCSE Bulletin, no. 28, pp. 28-32, 1996.

[Bro00a] Brodlie, K.; Lovegrove, S.; Wood, J. - "Harnessing the Web for Scientific Visualization", ACM SIGGRAPH Computer Graphics, vol. 34, no. 1, pp. 10-12, 2000.

[Bro00b] Brodlie, K.; El-Khalili, N.; Li, Y. - "Using Web-based Computer Graphics to Teach Surgery", Computer \& Graphics, vol. 24, no.I, pp. 157-161, 2000.

[Bro00c] Brodlie, K.; Wood, J. - "Volume Graphics and the Internet", Volume Graphics, Springer, pp. 317-331, ISBN $1852331925,2000$.

[Cas97] Castier, B.; Reis, L. P.; Cohen, M. - "Tutorial de VRML". Disponível on-line em: http://brahma.incc.br/sibgrapi97/cursos/vrml/top.htm. Visitado em 11 de dezembro de 1998. 
[Ces97] Cesar Jr., R. M.; Costa, L. F. - "Semi-Automated Dendogram Generation for Neural Shape Analysis", Proceedings SIBGRAPI'97, Campos do Jordão, São Paulo, pp. 147-154, 1997.

[Cha98] Chang, Y.; Coddington, P.; Hutchens, K. - "Viewing the Visible Human using Java and the Web", Proceedings of Asia Pacific Web (APWeb)’98, Beijing, International Academic Publisers, 1998.

[Coe94] Coelho, R. C.; Costa, L. F. - "Gramáticas para Sínteses de Estruturas Neurais", Anais do Workshop sobre Visão Cibernética, São Carlos, IFSC-USP, pp. 74-79, 1994.

[Coe95] Coelho, R. C.; Costa, L. F. - "The Box-Couting Fractal Dimension: Does it Provide an Accurate Subsidy for Experimental Shape Characterization? If So, How to Use It?", Anais do SIBGRAPI'95, São Carlos, pp. 183-191, 1995.

[Co199] Colla, E.C. - "Servlet, java do lado do servidor". Disponível on-line em: http://www.insite.com.br/docs/develop-servlet95.html. Visitado em 03 de maio de 1999.

[Con99] O'Connor, T.; Viega, J. - "Signing Code with JDK 1.2". Disponivel on-line em: http://developer.earthweb.com/journal/techworkshop/101598 jsig.html. Visitado em 08 de agosto de 1999.

[Cor97] Cornell, G.; Horstmann, C. S. - Core Java, Makron Books, 1997.

[Cos00] Costa, L.F.; Oliveira, M.C.F.; Minghim, R. - "Visualizando as Formas do Pensamento", Ciência Hoje, 2000 , a ser publicado.

[Coy99] Coyle, A. - "Web-based Visualization". Disponível on-line em: http://www.scs.leeds.ac.uk/vis/webvis.html, agosto, 1999.

[Dag99] Dageforde, M. - "Security in Java 2 SDK 1.2". Disponível on-line em: http://jaya.sun.com/docs/books/tutorial/security1.2/index.html. Visitado em 30 de abril de 1999.

[Elv92] Elvins, T. T. - "A Survey of Algorithms for Volume Visualization", ACM SIGGRAPH Computer Graphics, vol. 26, no. 3, pp. 194-201, 1992.

[Eng98] Engel, K.; Grosso, R.; Ertl, T. - "Progressive Iso-surfaces on the Web", in Late Breaking Hot Topics, IEEE Visualization, 1998.

[Eng99] Engel, K.; Ertl, T. - "Texture-based Volume Visualization for Multiple Users on the World Wide Web", $5^{\text {th }}$ Eurographics Workshop on Virtual Environment, 1999.

[Fri99] Friesen, G - "Plug into Java with Java Plug-in". Disponível on-line em: http://www.javaworld.com/javaworld/jw-06-1999/jw-06-plugin p.html. Visitado em 30 de maio de 2000. (junho de 1999). 
[Gon97] Gong, L. - “Java Security:Present and Near Future”, IEEE Micro, vol.17, no.3, pp. 14-19, maio/junho, 1997.

[Gon99] Gong, L. - "Java Security Architecture". Disponível on-line em: http://java.sun.com/products/jdk/1.2/docs/guide/security/spec/security-spec.doc.html. Visitado em $25 \mathrm{de}$ junho de 1999.

[Gos96] Gosling, J; Yellin, F. - "Java API Documentation", Sun Microsystems. Disponível on-line em: http://java.sun.com/products/jdk/1.0.2/api/, 1996.

[Gri99a] Griscom, D. - "Signing code for Microsoft Internet Explorer". Disponível on-line em: http://www.suitable.com/CodeSigningSignExp.shtml. Visitado em 17 de julho de 1999.

[Gri99b] Griscom, D. - "Signing code for Netscape Navigator". Disponível on-line em: http://www.suitable.com/CodeSigningSignNav.shtml. Visitado em 17 de julho de 1999.

[Gun96] Gundavaran, S. - CGI Programming on the World Wide Web, O'Reilly \& Associates, Inc., 1996.

[Hib97] Hibbard, W.; Anderson, J.; Paul, B. - "A Java and World Wide Web Implementation of VisAD", Preprints of Conf. Interactive Information and Processing Systems for Meteorology, Oceanography, and Hydrology, pp. 174-177, 1997.

[Hib98] Hibbard, B.; - "VisAD: Connecting People to Computations and People to People", ACM SIGGRAPH Computer Graphics, vol. 32, no. 3, pp. 10-12, 1998.

[Hib00] Hibbard, B. - "Vis-5D Web Site". Disponível on-line em: http://www.ssec.wisc.edu/ billh/view5d.html. Visitado em 03 de junho de 2000.

[Jam97] Jamsa, K.; Lalani, S.; Weakley, S. - Web Programming, Jamsa Press, 1997.

[Jer98] Jern, M. - "Information Visualization on the Web", Proceedings IEEE Int. Conf. On Information Visualization, 29 a 31 de julho, Londres, pp. 2-7, 1998.

[Joh98] Johnson, G. - "Introduction to Collaborative Visualization", ACM SIGGRAPH Computer Graphics, vol. 32 , no. 2,1998 .

[Kau93] Kaufman, A.; Cohen, D.; Yagel, R. - "Volume Graphics", IEEE Computer, pp. 51-64, 1993.

[Kha97] El-khalili, N.H; Brodlie, K. W. - "Distributed V.R. Training System for Endovascular Procedures", Proceedings of Fourth UK VRSIG Conference, pp. 110-119, 1997.

[Kha98] El-Khalili, N.H.; Brodlie, K.W. - "Architectural Design Issues for Web-based Virtual Reality Training Systems", Proceedings of the 1998 International Conference on Web-based Modeling and Simulation, pp. 153-158, 1998. 
[Kov98] Koved, L.; Nadalin, A.J.; Neal, D.; Lawson, T. - "The evolution of Java security", IBM System Journal, vol. 37 , no. 3, pp. 349-364, 1998 .

[Lem96] Lemay, L.; Perkins, C. L. - Teach Yourself Java in 21 days, Sams Net Publishing, 1996.

[Lem98] Lemay, L.; Cadenhead, R. - Teach Yourself Java 1.2 in 21 days, Sams Net Publishing, 1998.

[Li00] Li, Ying; Brodlie, K; Phillips, N. - "Web-based VR Training Simulator for Percutaneous Rhizotomy", Medicine Meets Virtual Reality 2000, IOS Press, pp. 175-181, 2000.

[Liu96] Liu, P. W.; Chen, L. S.; Chen, S. C.; Chen, J. P.; Lin, F. Y.; Hwang, S. S.; - "Distributed Computing: New Power for Scientific Visualization", IEEE Computer Graphics and Applications, vol. 16, no. 3, pp. 42-51, 1996.

[Lor87] Lorensen, W. E. - "Marching Cubes: A High Resolution 3D Surface Construction Algorithm", ACM SIGGRAPH Computer Graphics, vol. 21, pp. 163-169, 1987.

[Mar97] Martins, A. L.; Oliveira, M. C. F.; Minghim, R. - "Visualização Científica em Mecânica dos Fluidos", Notas do ICMC/Série Computação, no. 034/97, 44p., março de 1997.

[McC87] McCormick, B. H.; De Fanti, T. A.; Brown, M. D. - "Visualization in Scientific Computing: A Synopsis", IEEE Computer Graphics and Applications, vol. 7, no. 7, pp. 61-70, 1987.

[McG99] McGraw, G.; Felten, E. - Securing Java, John Wiley \& Sons, Inc., 1999.

[Mic97] Michaels, C.; Bailey, M. - "VisWiz: A Java Applet for Interactive 3D Scientific Visualization on the Web", Proceedings IEEE Visualization'97, 19 a 24 de outubro, Phoenix, AZ, pp. 261-267, 1997.

[Min97a] Minghim, R.; Oliveira, M. C. F. - "PowerVis: Empowering the User with a Multi-Modal Visualization System", Proceedings II Workshop on Cybernetic Vision, dezembro de 1996, IEEE CS Press, pp. 106$111,1997$.

[Min97b] Minghim, R.; Oliveira, M. C. F. - "Uma Introdução à Visualização Computacional", XVI JAI Jornadas de Atualização em Informática, XVII Congresso da Sociedade Brasileira de Computação, pp. 85-I31, 1997.

[Min98] Minghim, R.; Oliveira, M. C. F. - "Visualization Experiences in the Light of Visualization Effectiveness", Proceedings Int. Symposium on Advances on Signal, Image Processing, Computer Vision and Graphics of the World Multiconference on Systemics, Cybernetics and Informatics (SCI-98), 12 a 16 de julho, Orlando, USA, pp. 529-536, 1998.

[Nad97] Nadeau, D.; Grantham, B.; McCartney, C.; Mitra; Sowizral, H. - "What 3D API for Java should I use and why?", Proceedings SIGGRAPH 97, 3 a 8 de agosto, Los Angeles, California, pp. 452-453, 1997.

[Nau96] Naughton, P. - The Java Handbook, McGraw-Hill, 1996. 
[Net98] Netto, A. V. - "Prototipaçāo de um torno CNC utilizando Realidade Virtual", Dissertação (Mestrado), Escola de Engenharia de São Carlos - USP, São Carlos, 1998.

[Nic97] Nicholas, C. K.; Mayfield, J. - "Intelligent Hypertext: Advanced Techniques for the WWW", Lecture Notes in Computer Science, Berlin, Springer, New York, 1997.

[Oli98] Oliveira, M.C.F.; Minghim, R.; Tutida, S.M.; Salvador, V.C.L. - "Towards Perception Driven Visualization", Proceedings SIBGRAPI'98, 20 a 23 de outubro, Rio de Janeiro, Brasil, pp. 127-134, 1998.

[Pau00] Paula, C.E. - "Interface Gráfica Interativa para Definiçăo de Tabelas de Cores em Visualização", Dissertação (Mestrado), ICMC-USP, São Carlos, 2000.

[Paw99a] Pawlan, M. - "Is the Only Really Secure Computer is Disconnected Computer?". Disponível on-line em: http://developer.java.sun.com/developer/technicalArticles/Security/ReallySecure/index.html. Visitado em 03 de agosto de 1999.

[Paw99b] Pawlan, M.; Dodda, S. - "Signed Applets, Browsers, and File Acess". Disponível on-line em: http://developer.java.sun.com/developer/technicalArticles/Security/Signed/index.html. Visitado em 03 de agosto de 1999.

[Rhy95] Rhyne, T. M.; Martin, L. - "A WWW Viewpoint on Scientific Visualization: An EPA Case Study for Technology Transfer", Proceedings IEEE Visualization'95, pp. 112-114, 1995.

[Roh97] Rohrer, R. M.; Swing, E. - "Web-Based Information Visualization", IEEE Computer Graphics and Applications, vol. 17, no. 4, pp. 52-59, 1997.

[Sch98] Schroeder, W. J.; Martin, K.; Lorensen, B. - The Visualization Toolkit - An Object-Oriented Approach to 3D Graphics, $2^{2}$ Edição, Prentice-Hall, 1998.

[Sch99] Schorr, N. - "Using the Java Plug-in Converter". Disponível on-line em: http://java.sun.com/products/jfc/tsc/web/converter/converter.html. Visitado em 08 de setembro de 1999.

[Sch00] Schroeder, W.J.; Martin, K.M.; Avila, L.S.; Law, C.C. - The VTK User's Guide, Kitware, Inc., 2000.

[Sei99] Seidman, G. - "The Java Plug-in: using the newest versions of Java with your old browser". Disponivel on-line em: http://developer.earthweb.com/journal/techfocus/051198 javaplugin.html. Visitado em $08 \mathrm{de}$ agosto de 1999.

[Som99] Sommerer, A. - "JAR Files". Disponível on-line em:

http://java.sun.com/docs/books/tutorial/jar/index.html. Visitado em 30 de abril de 1999.

[Sow97] Sowizral, H.; Rushforth, K.; Deering, M. - The Java 3D API Specification, Addison-Wesley, 1997.

[Sun96] The Java Tutorial. Disponível on-line em: http://java.sun.com. Visitado em 11 de dezembro de 1998. 
[Sun99a] "JDK 1.2 - Signed Applet Example". Disponível on-line em: http://java.sun.com/security/signExample12/. Visitado em 08 de agosto de 1999.

[Sun99b] "Java Plug-in 1.2.2 Overview". Disponível on-line em: http://java.sun.com/products/plugin/1.2/overview.html. Visitado em 03 de agosto de 1999.

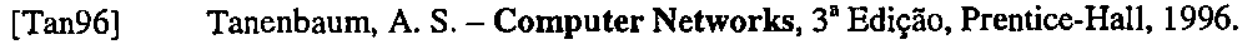

[Thi99] Thiesel, H. - "CurVis Mobile Curvature Visualizer". Disponível on-line em: http://www.informatik.uni-rostock.de/Projekte/movi/proto.htmI\#CURVIS, agosto, 1999.

[Tho96] Thomas, M. D.; Patel, P. R.; Hudson, A. D.; Ball Jr., D. A. - Java Programming for the Internet: A Guide to Creating Dynamic, Interactive Internet Applications, Ventana Comunications Group, 1996.

[Tut98] Tutida, S.M. - "Mapeamento por Cores Baseado em Aspectos de Percepção Visual", Dissertação (Mestrado), ICMC-USP, São Carlos, 1998.

[Ups89] Upson, C.; Faulhaber Jr., T. A.; Kamins, D.; Laidlaw, D.; Schlegel, D.; Vroom, J.; Gurwitz, R.; Dam, A. V. - "The Application Visualization System: A Computational Environment for Scientific Visualization", IEEE Computer Graphics and Applications, vol. 9, no. 4, pp. 30-42, 1989.

[Vac98] Vacca, J. R. - VRML Clearly Explained, 2' edição, Academic Press, 1998.

[Vie99a] Viega, J.; O'Connor, T. - "Signing Java with Microsoft's Authenticode". Disponível on-line em: http://developer.earthweb.com/journal/techworkshop/102098 authenticode.html. Visitado em 16 de agosto de 1999.

[Vie99b] Viega, J.; O'Connor, T. - "Using the Netscape Object Signing Tool". Disponível on-line em: http://developer.earthweb.com/journal/techworkshop/100898 sig.html. Visitado em 16 de agosto de 1999.

[Wo095] Wood, J.; Wright, H.; Brodlie, K. - "CSCV - Computer Supported Collaborative Visualization", Proceedings of BCS Displays Group International Conference on Visualization and Modeling, 1995.

[Wo096] Wood, J.; Brodlie, K.; Wright, H. - "Visualization Over The World Wide Web And Its Application To Environmental Data”, Proceedings IEEE Visualization'96, 27 de outubro a 1 de novembro, São Francisco, California, pp. 81-86, 1996. 


\section{Apêndice}

Neste Apêndice são apresentados todos os pipelines de visualização implementados no VisWeb, mostrando também o código Java que implementa cada um desses pipelines. A título de ilustração, são apresentados exemplos de visualizações geradas por cada um deles. Esses pipelines foram usados nas applets de extração de superfícies, rendering volumétrico direto e visualização de vetores, que são os três módulos do VisWeb.

A Figura A.1 ilustra o pipeline para extração e exibição de uma isosuperfície, juntamente com um outline, que coloca uma "borda" em torno do conjunto de dados visualizado.

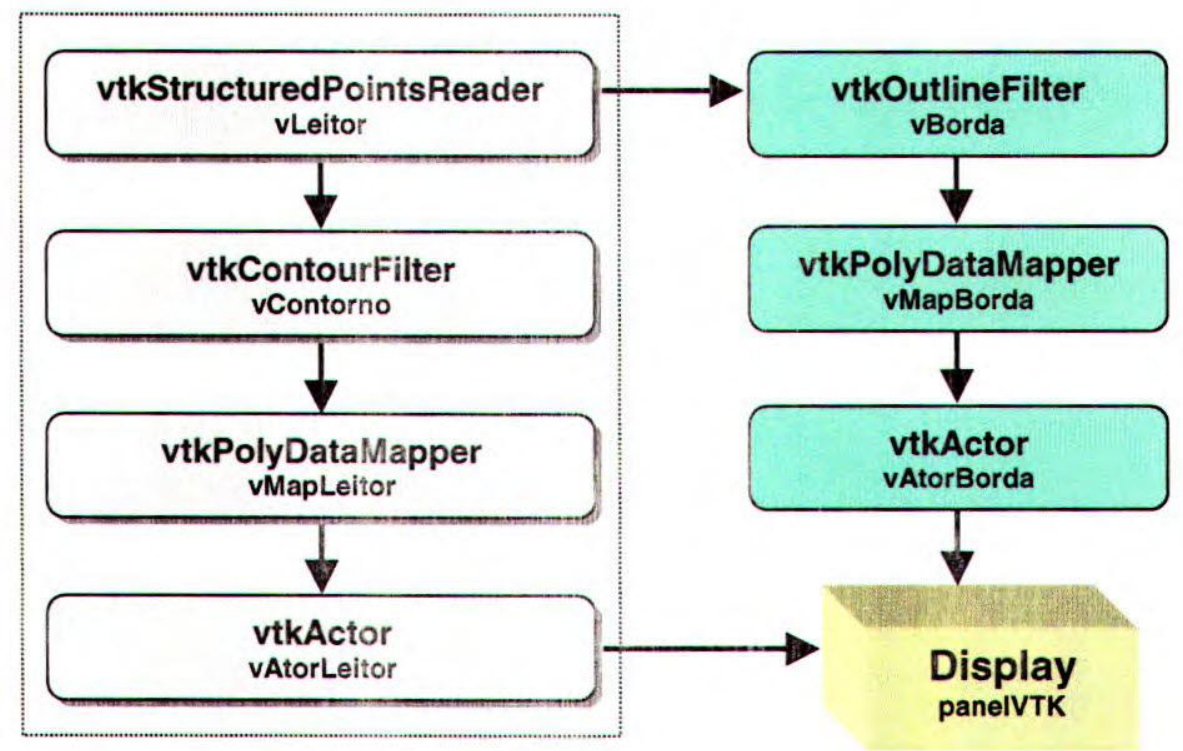

Figura A.1 - Pipeline para extração e exibição de isosuperfícies

A Listagem A.1 mostra o código-fonte de uma applet Java que interfaceia com o VTK para implementar o pipeline ilustrado na Figura A.1. Esse código está acessando o conjunto de dados "dente.vtk", que descreve o modelo de um dente, mas o pipeline opera sobre qualquer conjunto de dados escalares organizados em uma malha estruturada, que é o tipo de malha aceita pelo vtkContourFilter. O código para a inclusão do outline é incluído apenas nesse exemplo, apesar de fazer parte de todos os pipelines. 


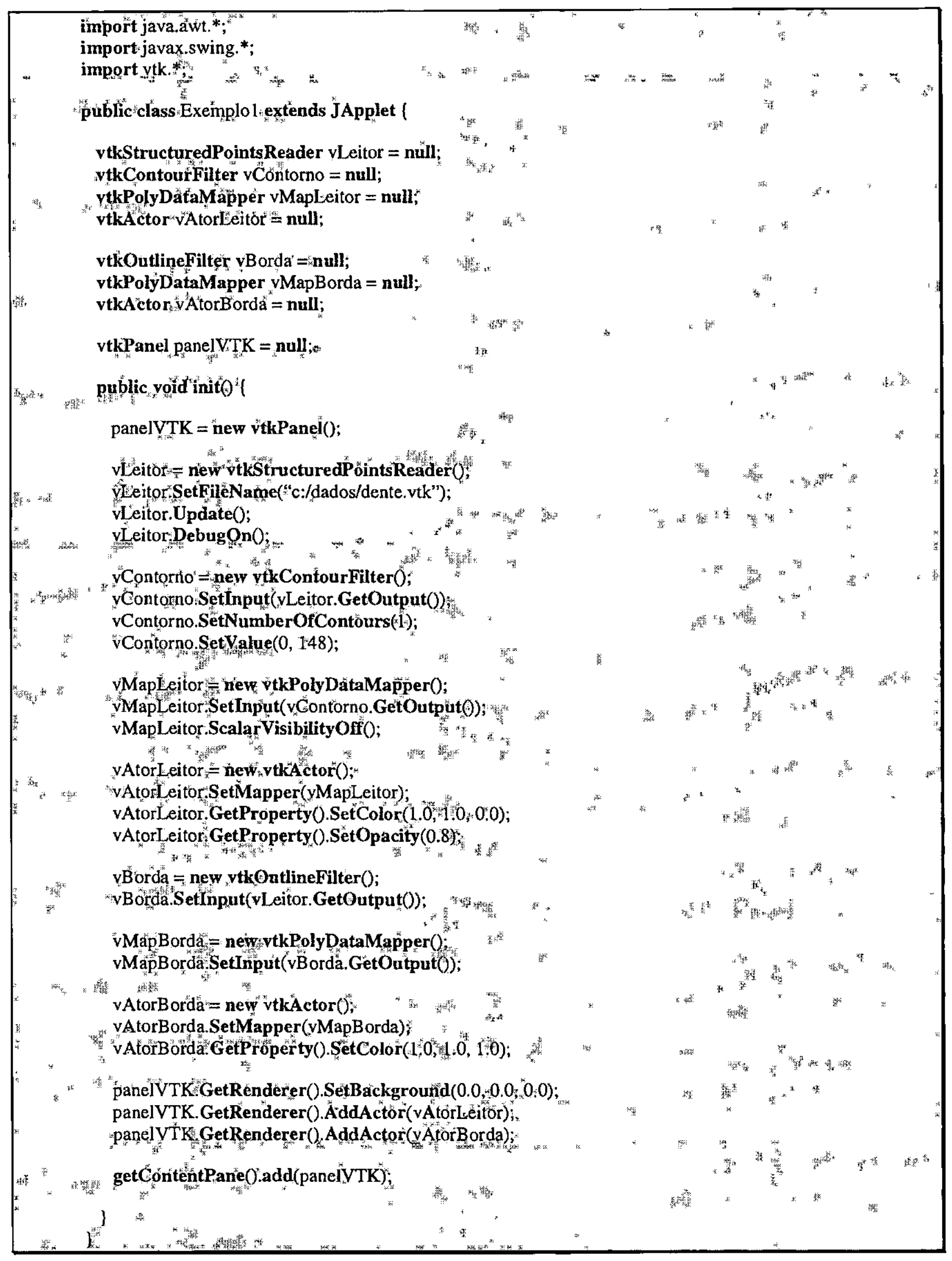

Listagem A.1 - Exemplo de uma applet Java para visualização de isosuperfícies 
A Figura A.2 ilustra duas visualizações geradas a partir do código na Listagem A.1. A Figura A.2 (a) ilustra uma visualização obtida por extração de uma isosuperfície de um conjunto de dados que descreve o modelo de um dente, e a isosuperfície na Figura A.2 (b) foi extraída de um conjunto de dados que descreve um neurônio (exibido sem o outline).

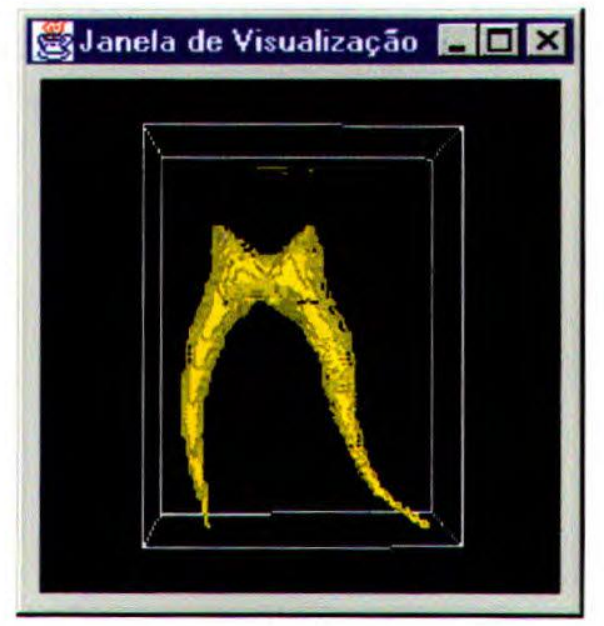

(a)

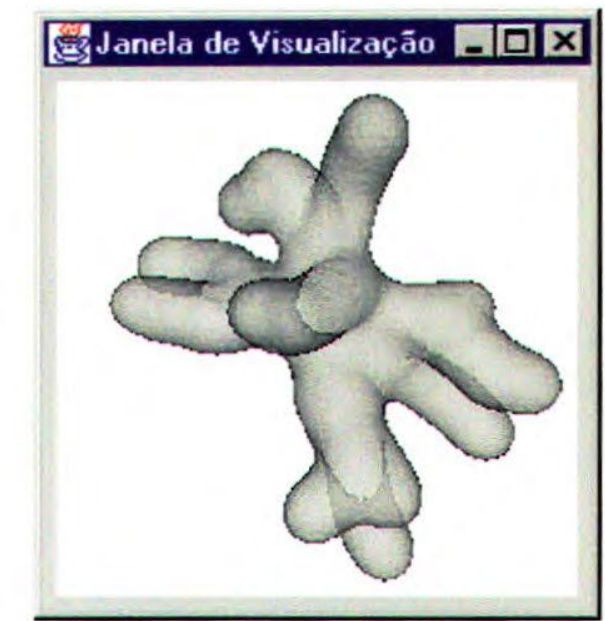

(b)

Figura A.2 - Exemplos de isosuperficies

É possível aplicar planos de corte sobre as superficies, como ilustrado no pipeline da Figura A.3.

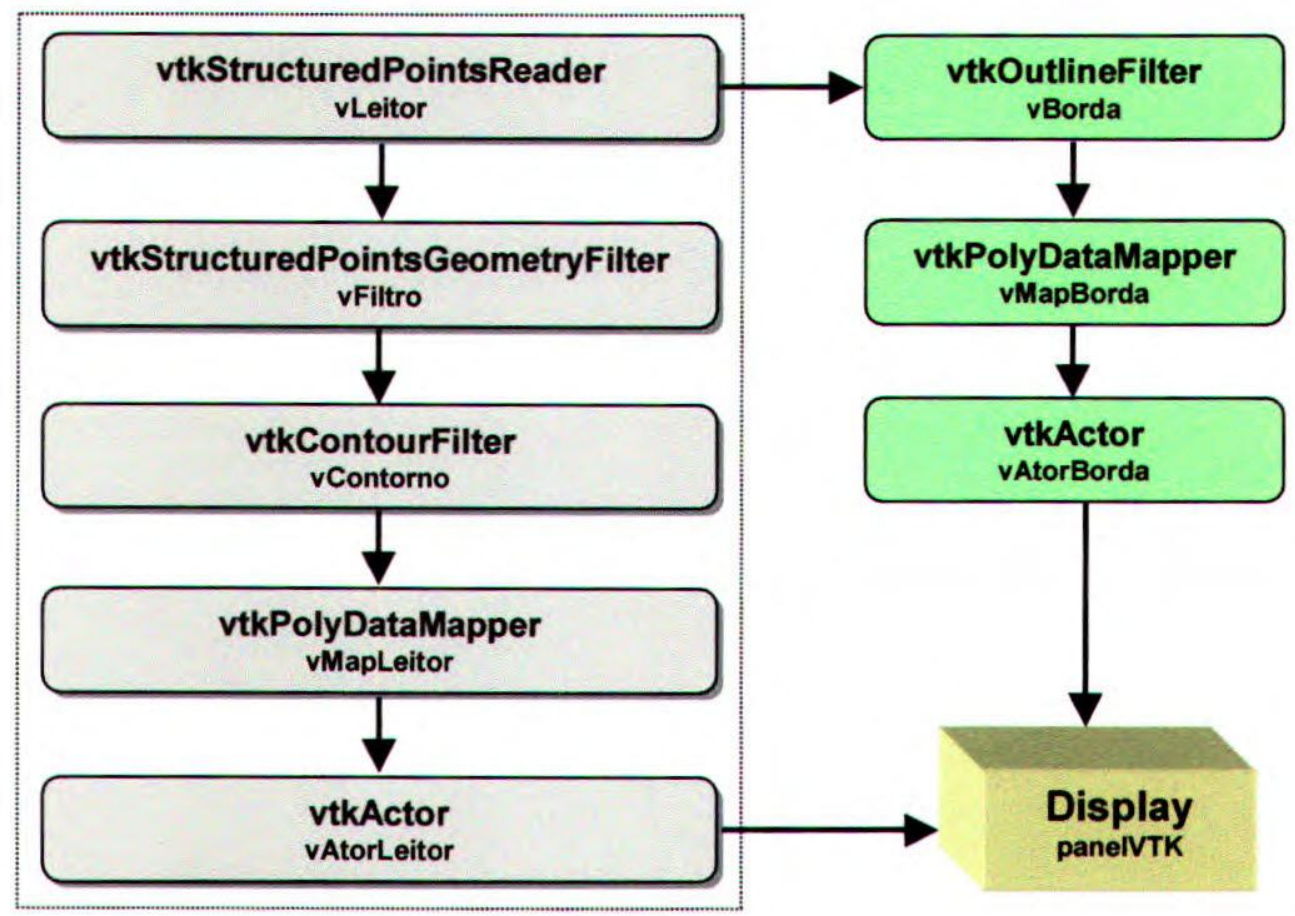

Figura A.3 - Pipeline para visualização de planos de cortes em isosuperfícies 
A Listagem A.2 mostra o código-fonte de uma applet que implementa o pipeline ilustrado na Figura A.3.

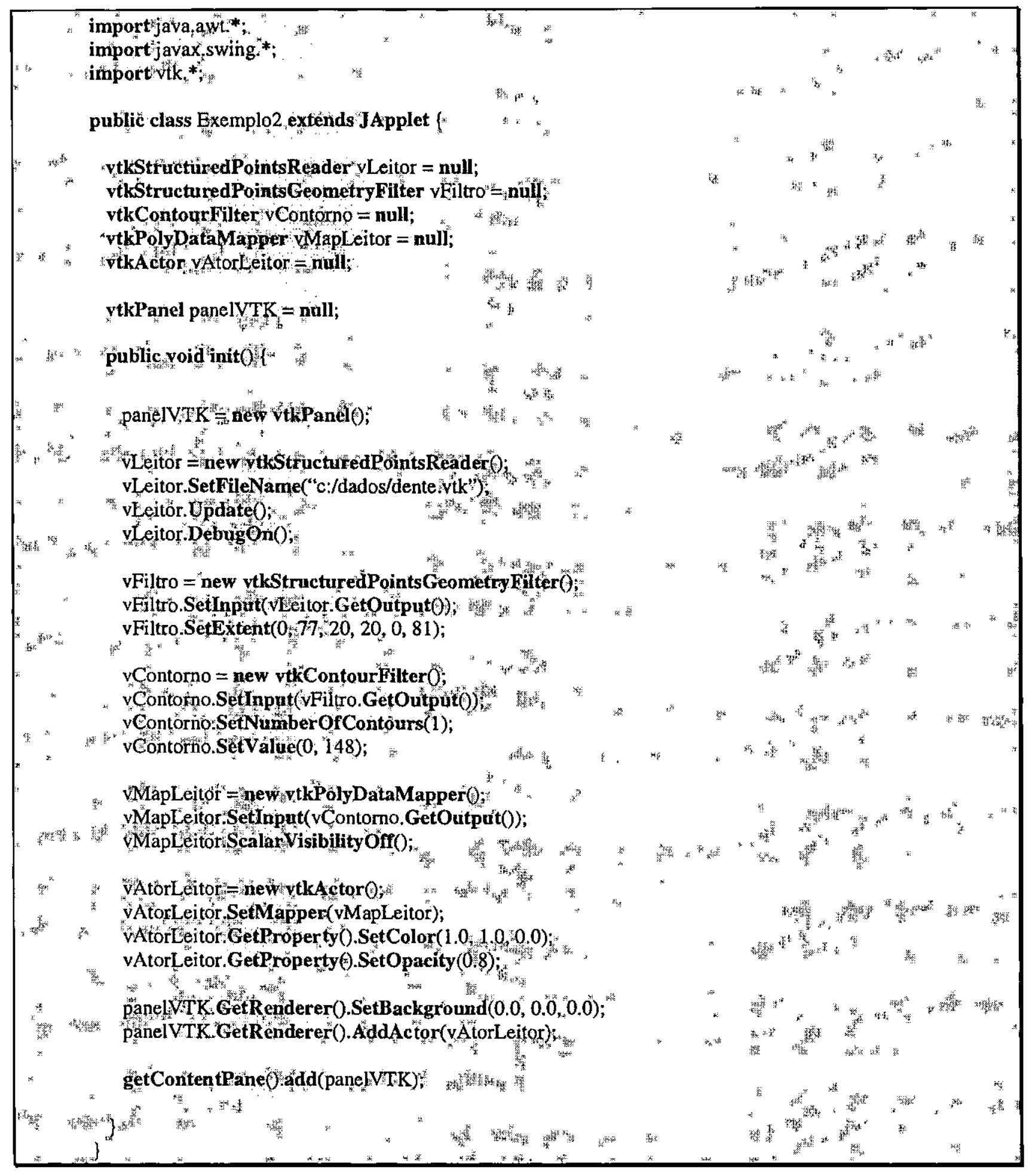

Listagem A.2 - Exemplo de uma applet Java que aplica um corte sobre uma isosuperficie 
A Figura A.4 ilustra planos de corte aplicados às isosuperfícies da Figura A.2
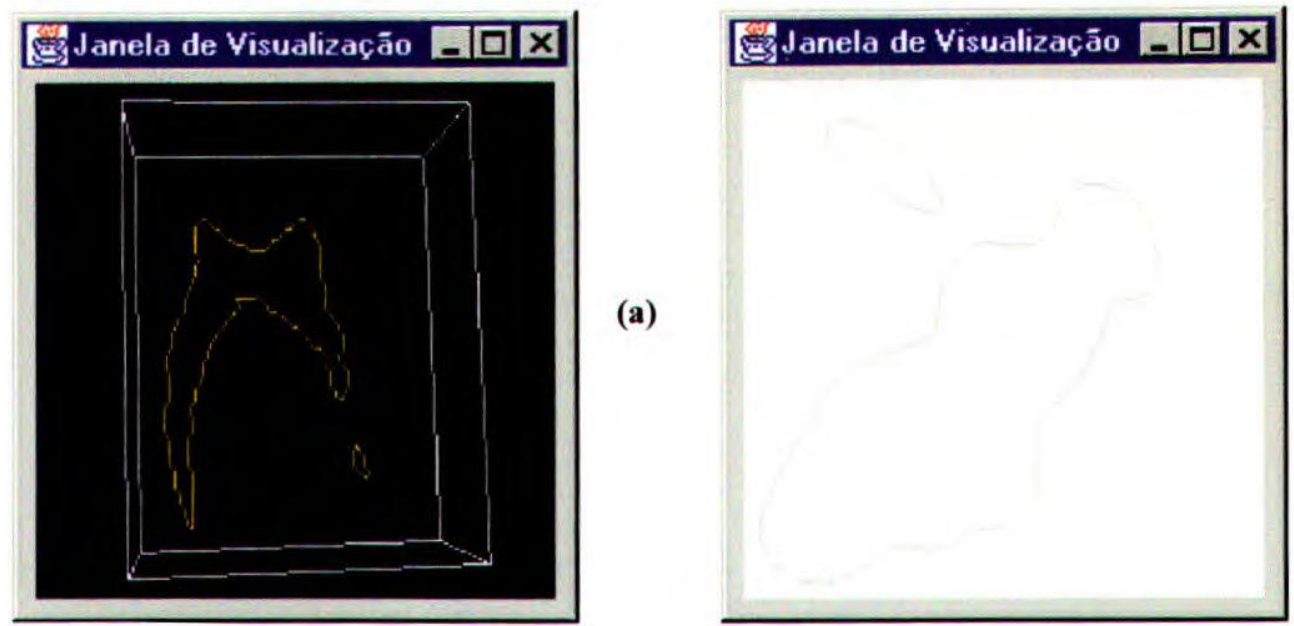

(b)

Figura A.4 - Exemplos de planos de corte aplicados às isosuperfícies ilustradas na Figura A.2

A Figura A.5 ilustra o pipeline para visualização de volumes utilizando a técnica de rendering volumétrico direto, com a classe do VTK que implementa o algoritmo de Ray Casting.

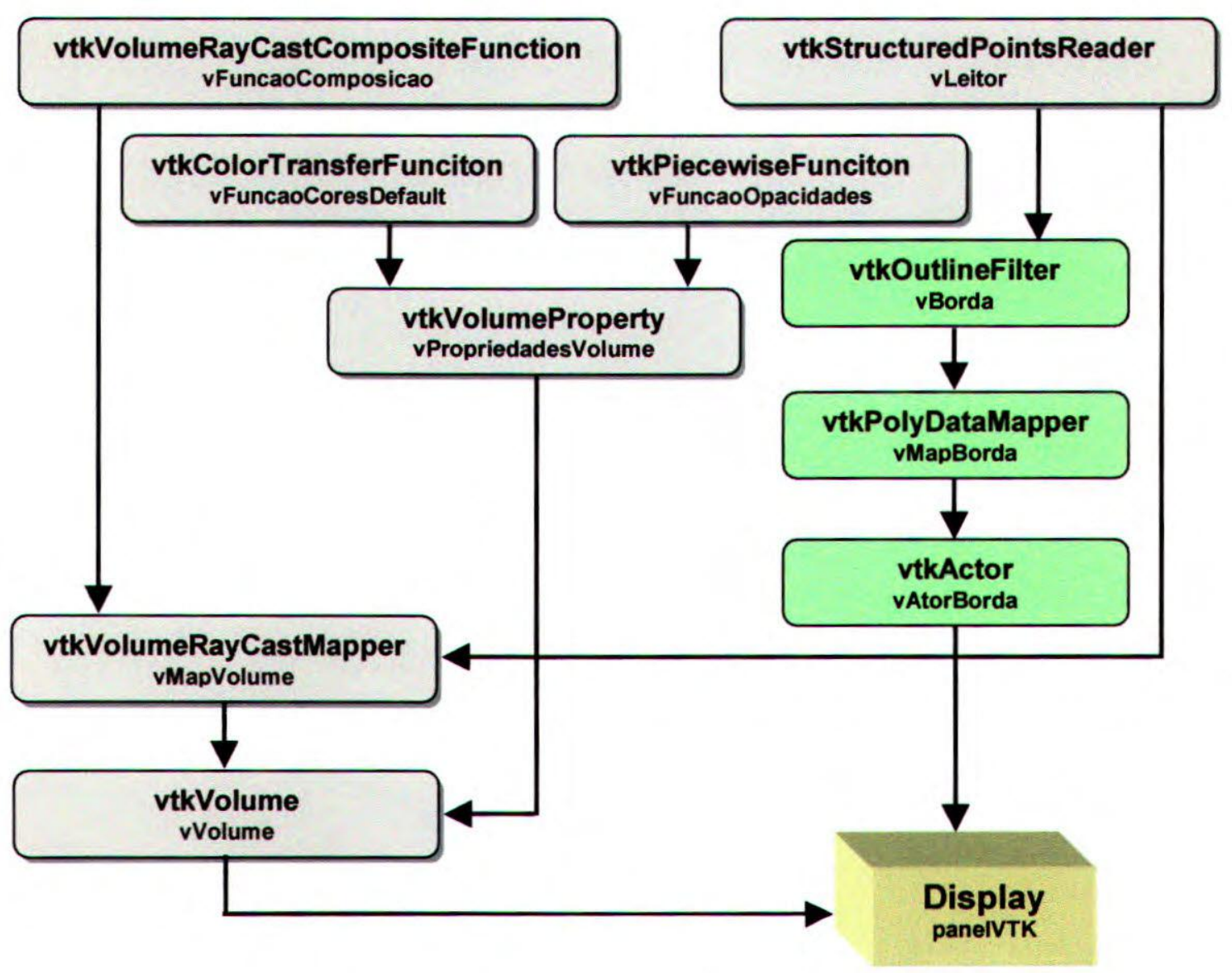

Figura A.5 - Pipeline para visualização de volumes 
A Listagem A.3 mostra o código-fonte de uma applet que implementa o pipeline ilustrado na Figura A.5.

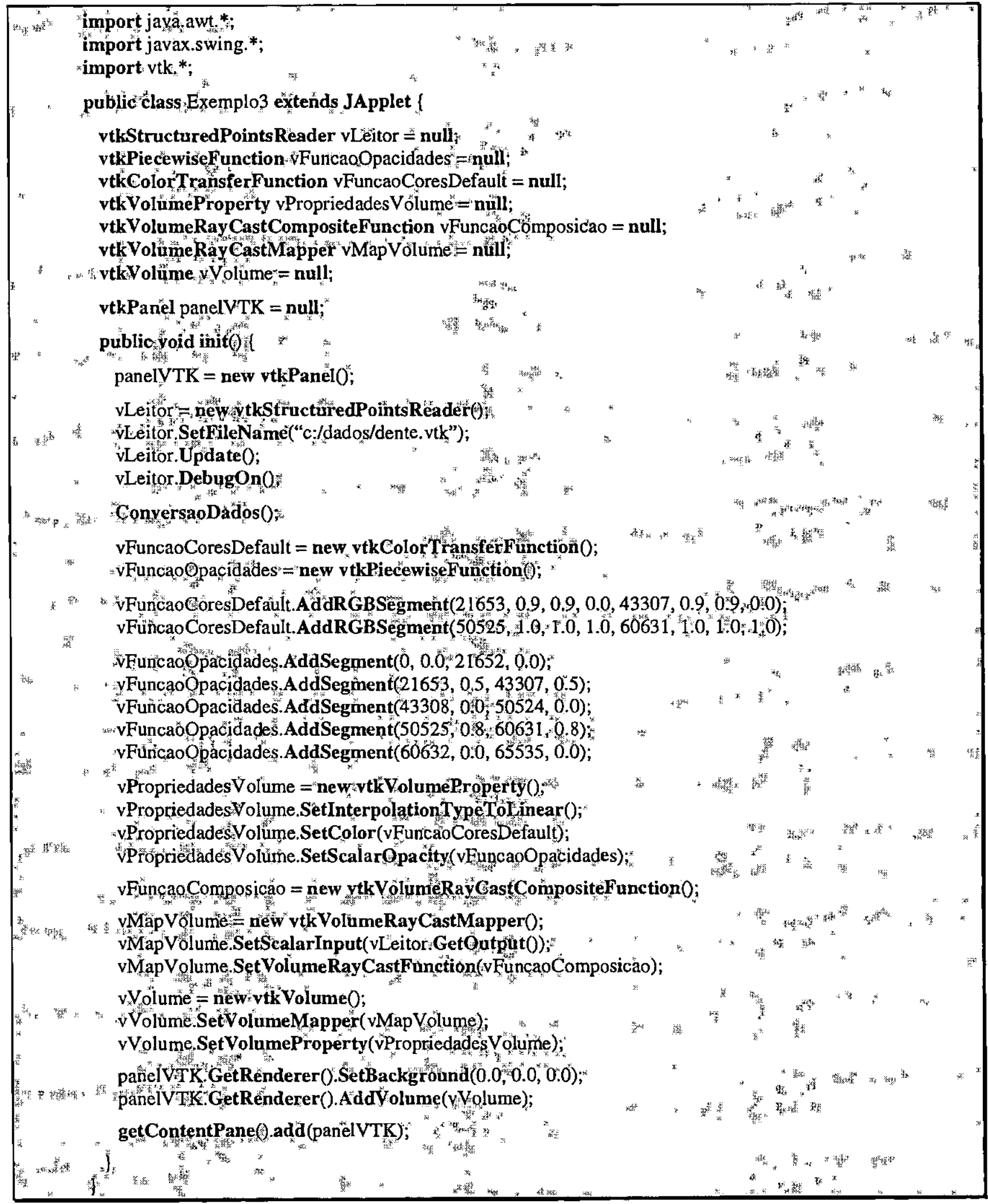

Listagem A.3 - Exemplo de uma applet Java para visualização de volumes 
A Listagem A.3 utiliza o método "ConversaoDados", que permite converter os dados escalares, que são do tipo float, em valores char, no intervalo [0..65535]. Essa conversão é necessária porque a classe $v t k$ VolumeRayCastMapper do VTK trabalha com valores inteiros (unsigned int). Os valores foram convertidos para char porque em Java não existe o tipo unsigned int, e char é o tipo cujo domínio de valores é dado pelo intervalo acima. A Listagem A.4 mostra a implementação desse método.

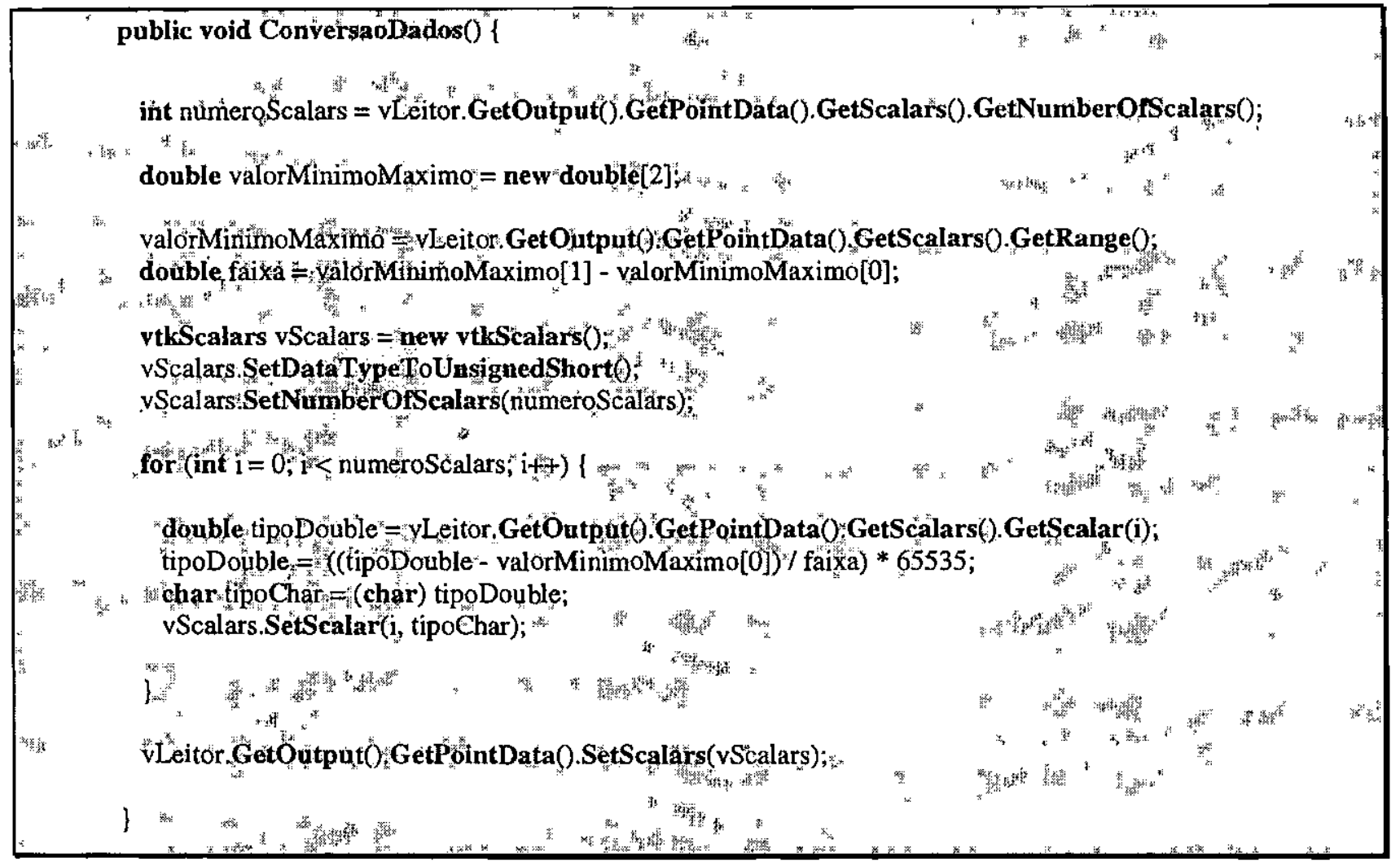

Listagem A.4 - Exemplo de um método em Java para conversão de dados escalares

A Figura A.6 ilustra visualizações volumétricas dos mesmos conjuntos de dados anteriores, usando o pipeline da Figura A.5. 

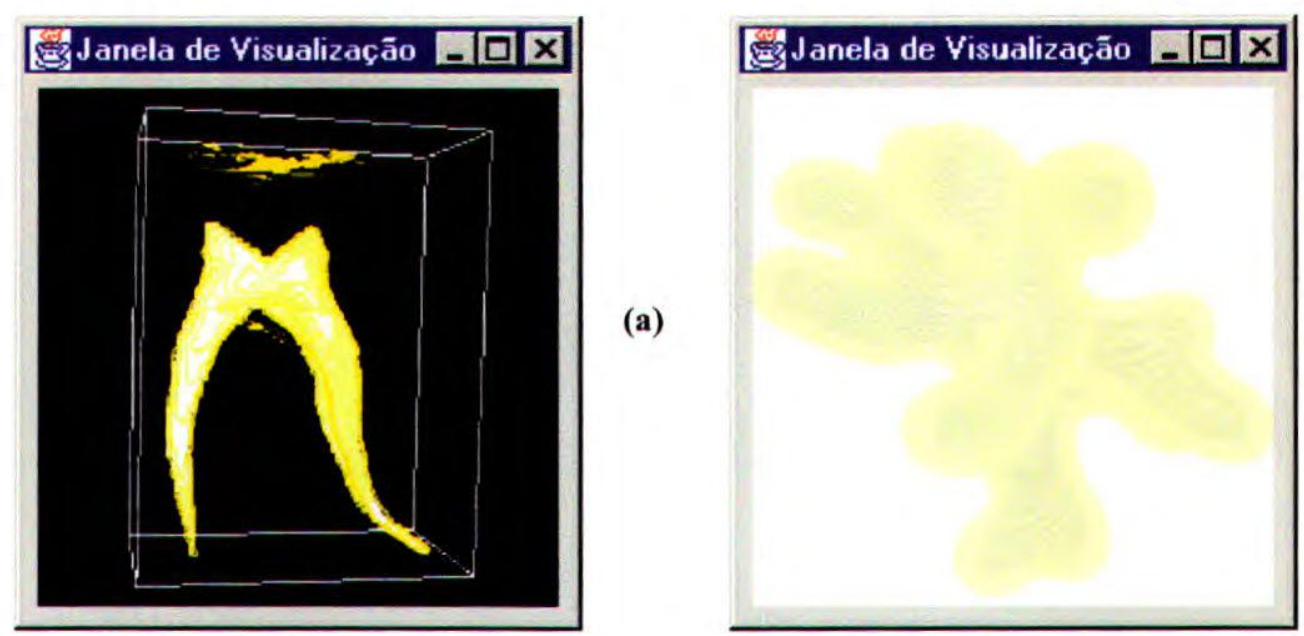

(b)

Figura A.6 - Exemplos de volumes

A Figura A.7 ilustra o pipeline para definição de sub-volumes, que permite especificar uma subregião do conjunto de dados. No caso, o sub-volume também está sendo visualizado por DVR, usando as classes vtkVolumeRayCastCompositeFunction e vtkVolumeRayCastMapper.

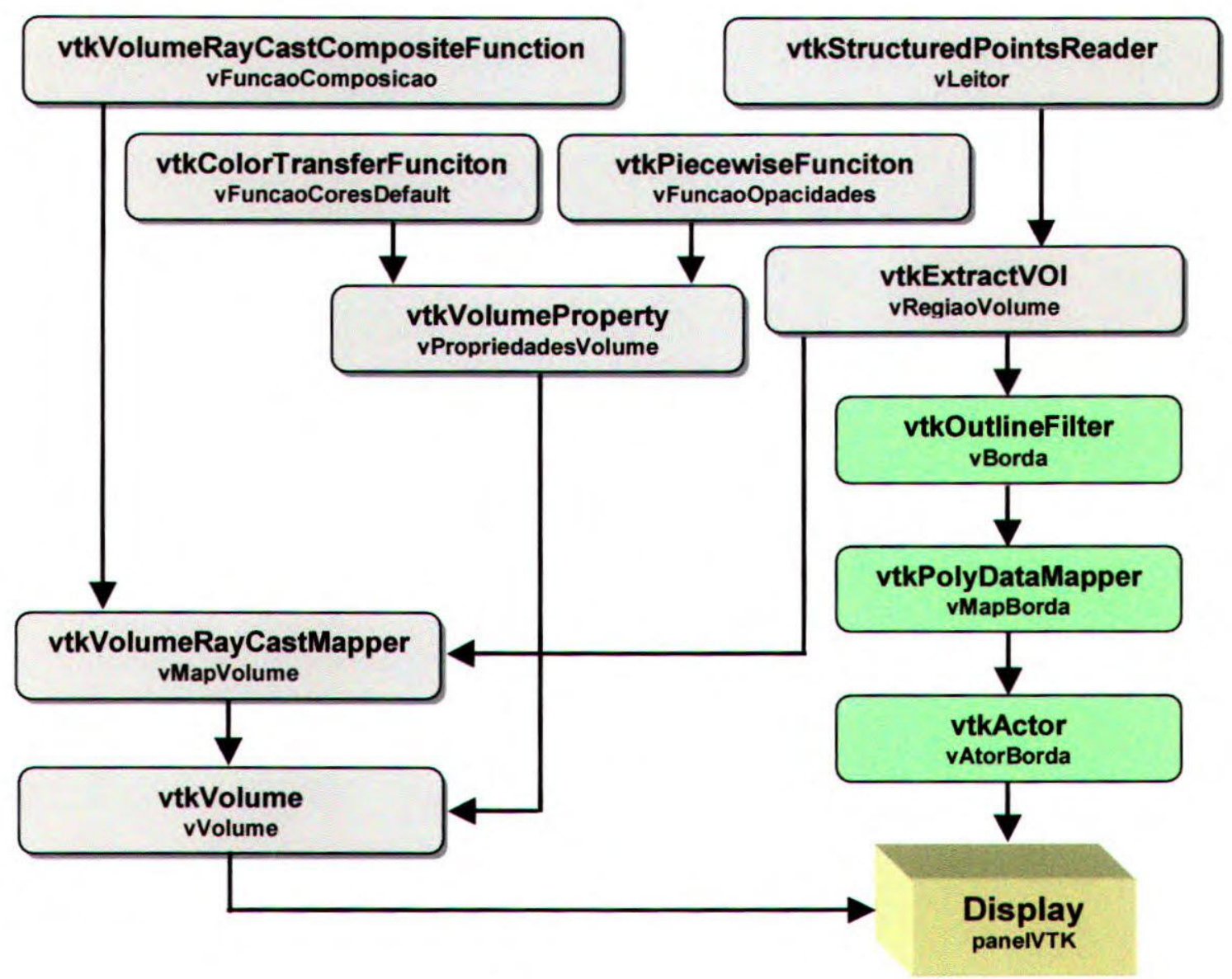

Figura A.7 - Pipeline para visualização de de sub-volumes 
A Listagem A.5 mostra o código-fonte de uma applet que implementa o pipeline ilustrado na Figura A.7.

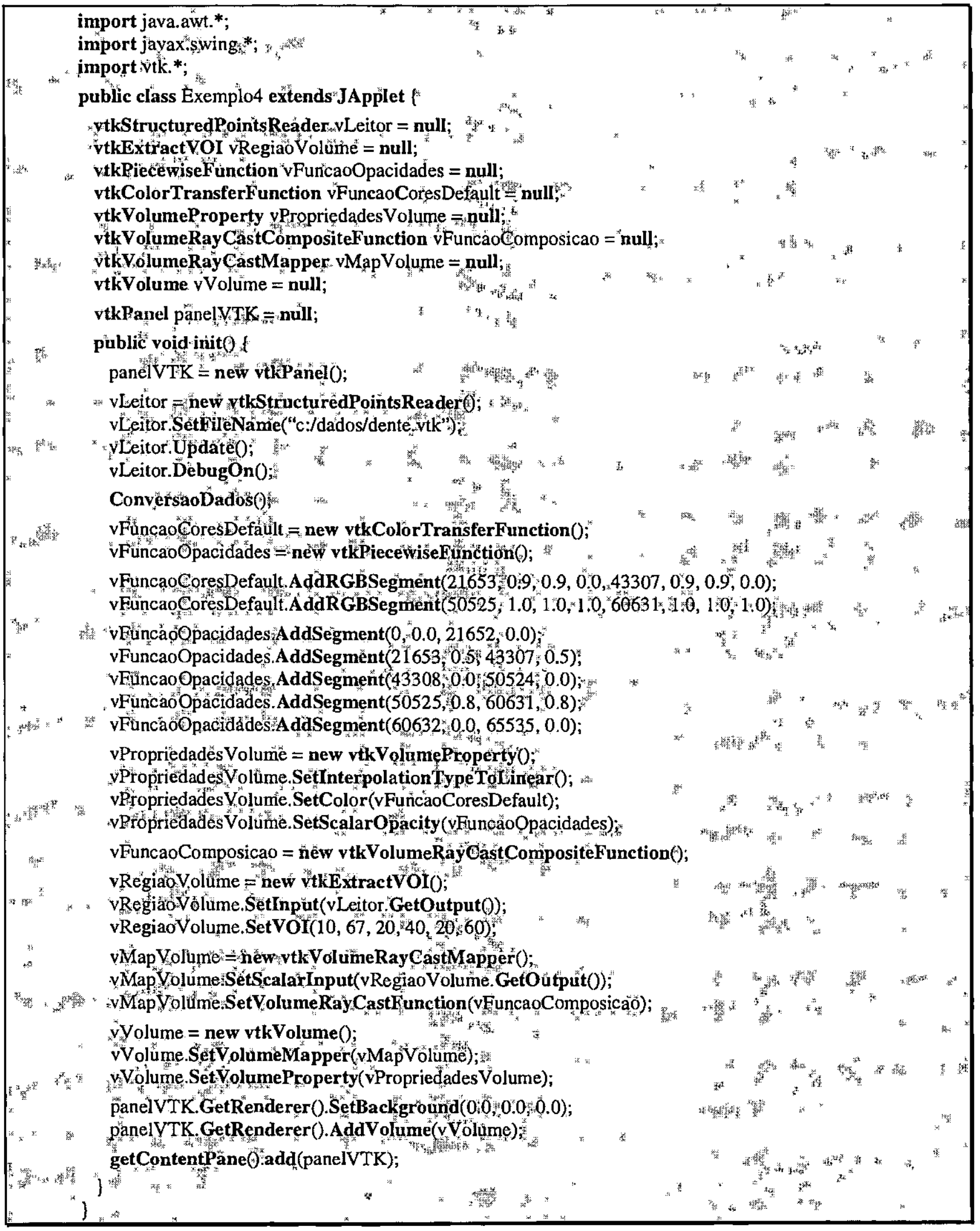

Listagem A.5 - Exemplo de uma applet Java para visualização de sub-volumes 
A Figura A.8 ilustra visualizações de sub-volumes dos dados de dentes (a) e neurônios (b).
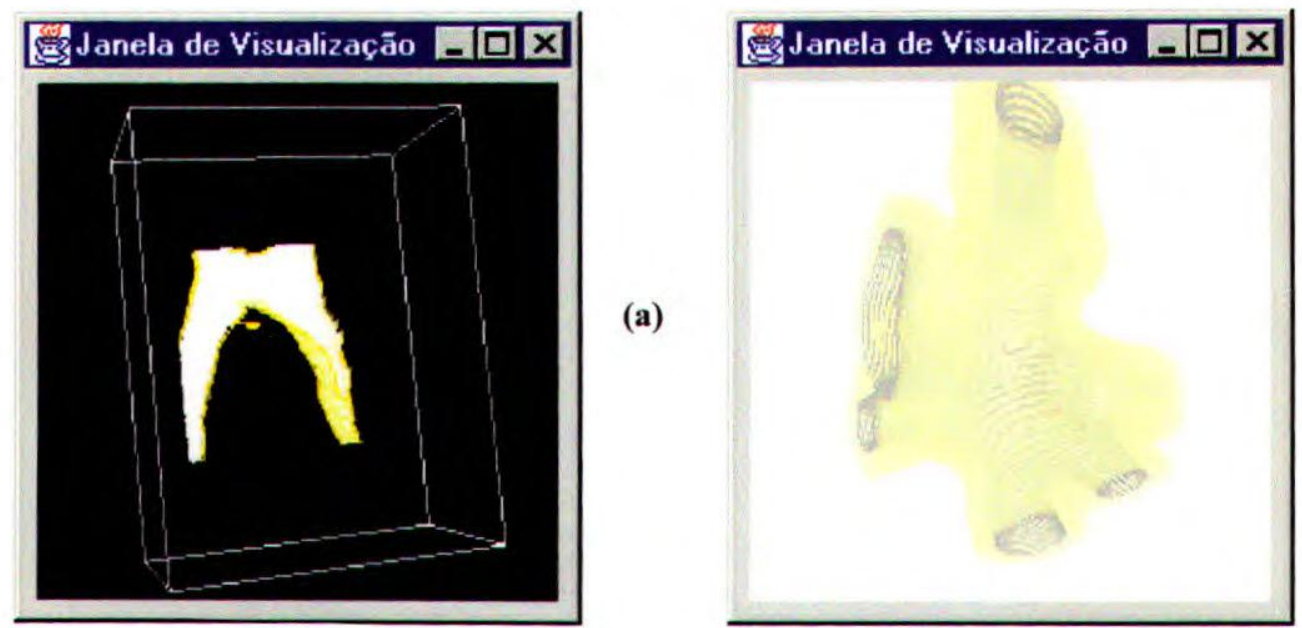

(b)

Figura A.8 - Exemplo de sub-volumes

O pipeline ilustrado na Figura A.7 também é utilizado para visualizar planos de corte nos volumes, o que é feito definindo-se um sub-volume com as mesmas dimensões do volume original nas direções x e y, mas com espessura igual a uma fatia na direção z. Essa solução é uma aproximação para o conceito de plano de corte aplicado às superfícies. A Figura A.9 ilustra visualizações de "planos de corte" nos volumes ilustrados na Figura A.6.
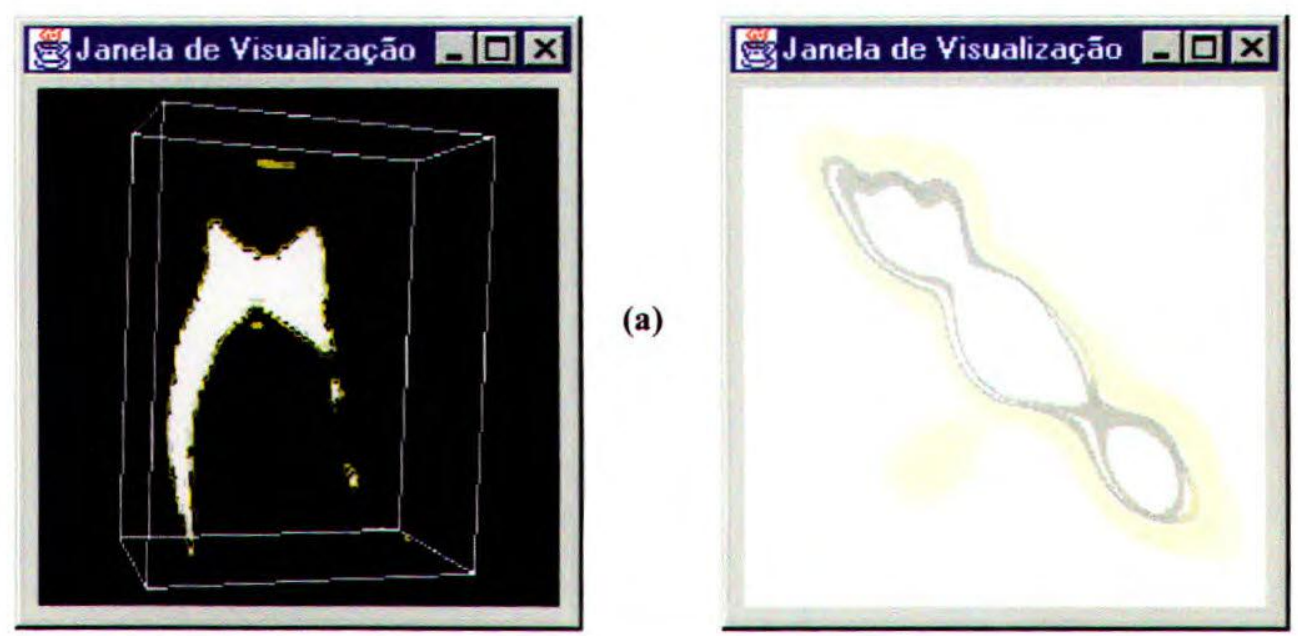

(b)

Figura A.9 - Exemplos de planos de corte nos volumes ilustrados na Figura A.6

A Figura A.10 ilustra o pipeline para visualização de campos vetoriais utilizando glyphs. Esse pipeline utiliza uma tabela de cores default (implementada no VTK pela classe vtkLookupTable), para mapear os intervalos de magnitude dos vetores. 


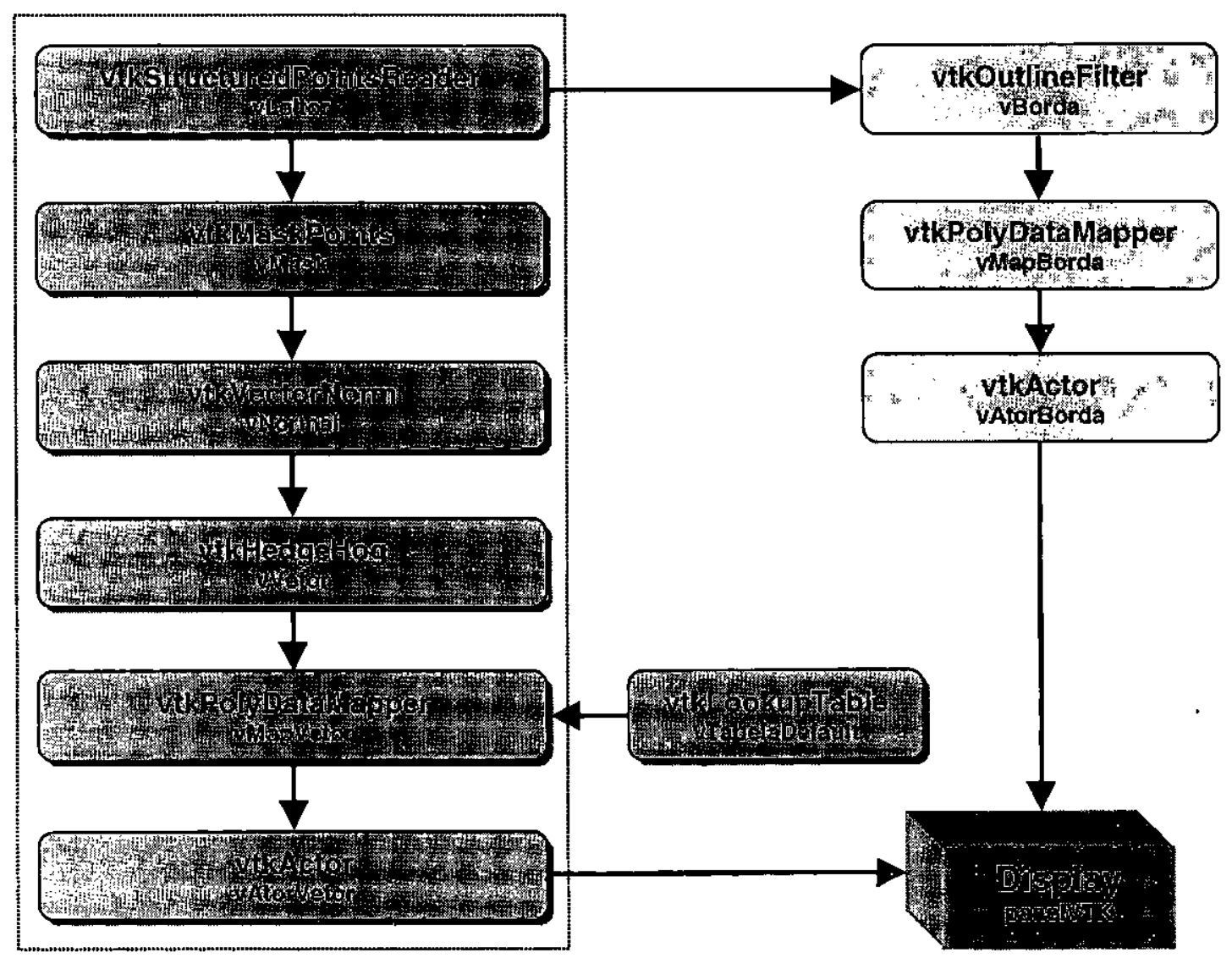

Figura A.10 - Pipeline para visualização de campos vetoriais

A Listagem A.6 mostra o código-fonte de uma applet que implementa o pipeline ilustrado na Figura A.10. Esse código está operando sobre o conjunto de dados "neu3d22.vtk", que descreve o campo vetorial em torno de um neurônio. O código pode ser utilizado para gerar visualizações similares de outros conjuntos de dados vetoriais.

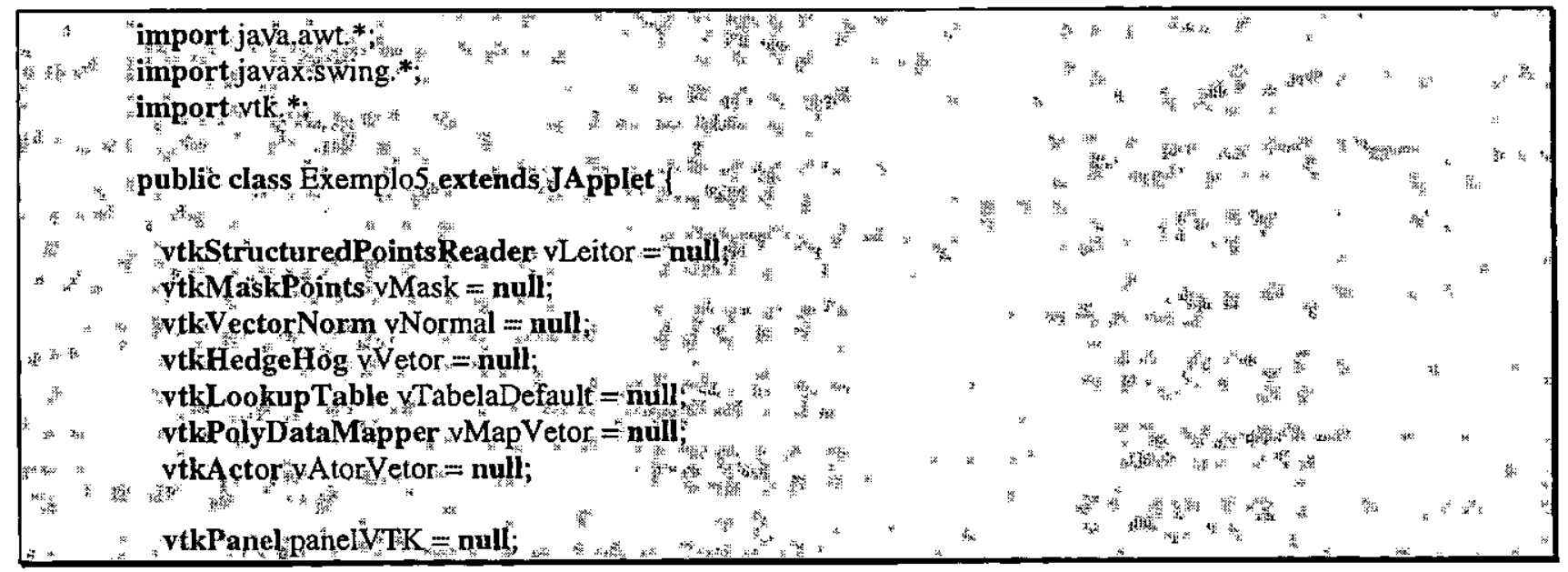




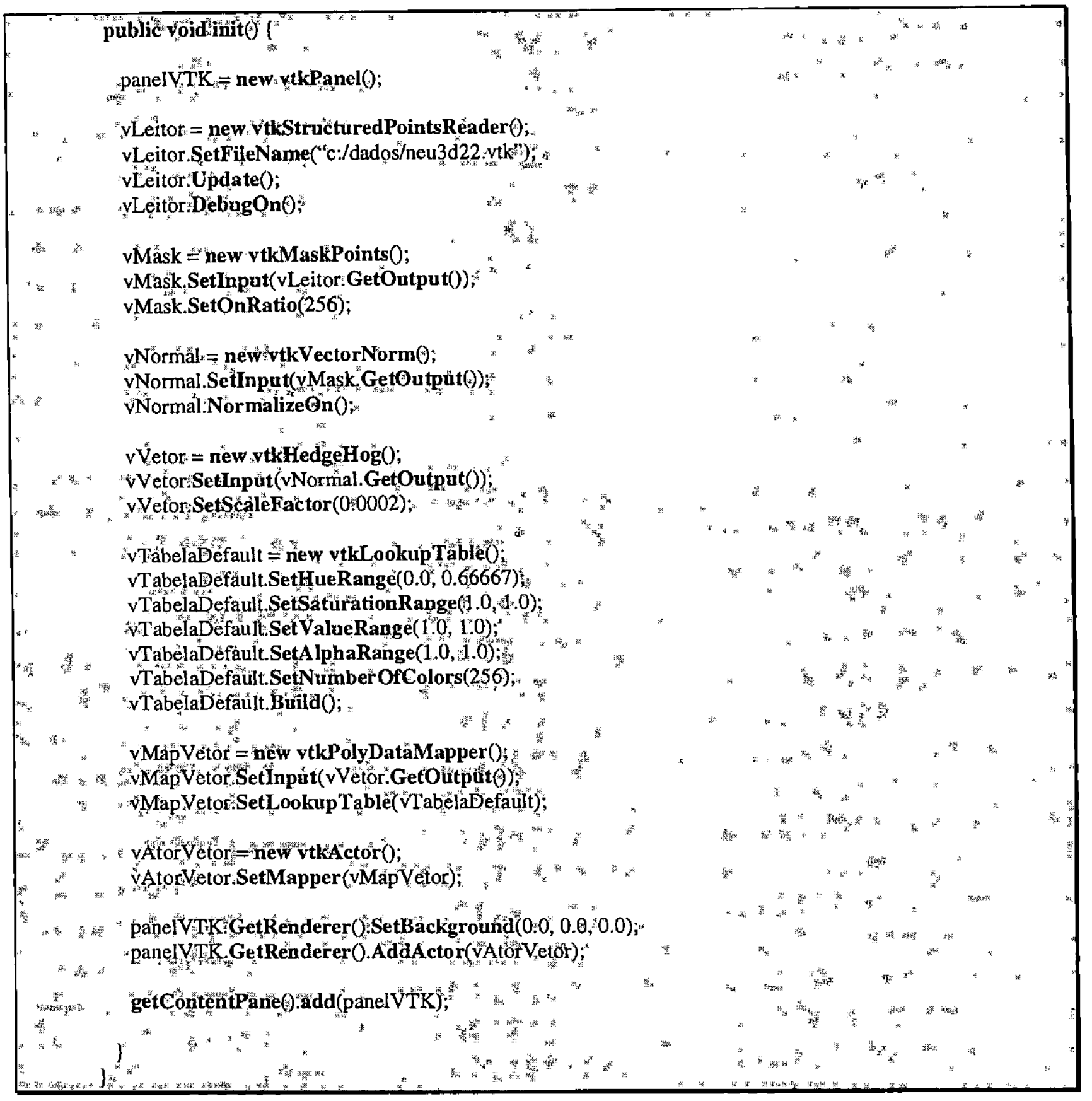

Listagem A.6 - Exemplo de uma applet Java para visualização de campos vetoriais

A Figura A.11 ilustra visualizações de campos vetoriais, em dois conjuntos de dados diferentes. Os segmentos de reta indicam a direção e a magnitude dos vetores do campo magnético, e as cores indicam a magnitude do campo, de acordo com a tabela de cores definida, que nesse caso é a default: vermelho, laranja e amarelo representam vetores com maiores magnitudes, e verde e azul indicam magnitude menores. 


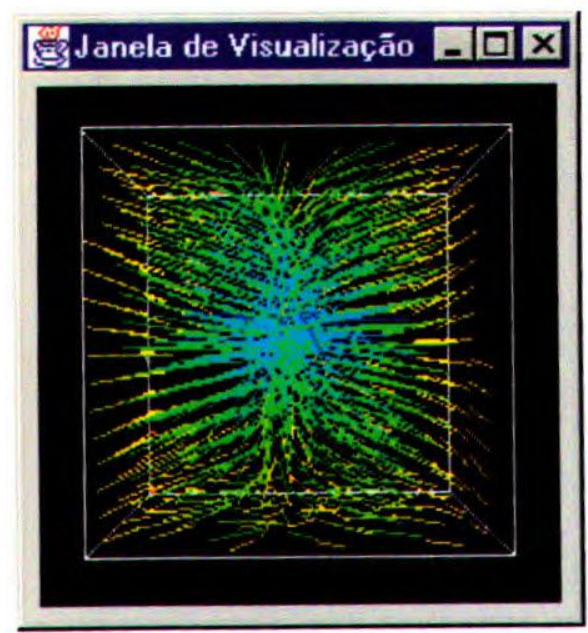

(a)

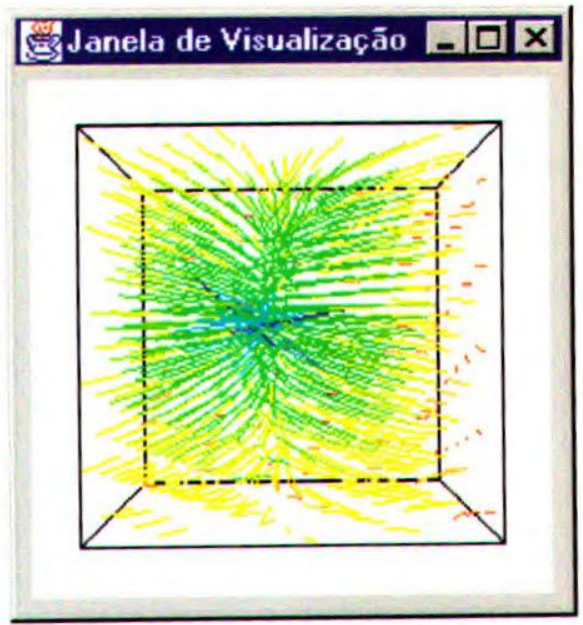

(b)

Figura A.11 - Exemplos de campos vetoriais

Todos os exemplos de código apresentados neste Apêndice e incluídos no VisWeb, utilizam a classe vtkPanel, que foi desenvolvida pelos criadores do VTK para ajudar a integrá-lo em uma aplicação (ou applet) baseada em Java. Ela permite à classe vtkRenderWindow aparecer como um Canvas normal de Java AWT [Sch00]. Nessa classe também estão implementadas as opções de interação com uma janela do VTK, sendo que não estão disponíveis todas as opções suportadas por uma janela convencional. Entretanto, é possível acrescentar as opções não disponíveis.

Todos os tipos de visualizações apresentadas neste Apêndice podem ser gerados no VisWeb, que fornece interfaces adequadas para a definição dos parâmetros relevantes para cada tipo de pipeline apresentado, de uma maneira simples e objetiva. 